ILMAR PEREIRA DO AMARAL JÚNIOR

\title{
EDUCAÇÃO PARA A DIFERENÇA É UM DIREITO: A adequação constitucional das políticas públicas de combate à homofobia nas escolas
}




\section{EDUCAÇÃO PARA A DIFERENÇA É UM DIREITO: A adequação constitucional das políticas públicas de combate à homofobia nas escolas}

Dissertação de Mestrado apresentada para a obtenção do título de Mestre pelo Programa de Pós-Graduação em Direito, Estado e Constituição da Universidade de Brasília (PPGD/UnB), sob orientação do Prof. Dr. Guilherme Scotti Rodrigues.

Programa de Pós-Graduação em Direito, Estado e Constituição da Universidade de Brasília Brasília, março de 2016 


\section{EDUCAÇÃO PARA A DIFERENÇA É UM DIREITO: A adequação constitucional das} políticas públicas de combate à homofobia nas escolas

Dissertação de Mestrado apresentada para a obtenção do título de Mestre pelo Programa de Pós-Graduação em Direito, Estado e Constituição da Universidade de Brasília (PPGD/UnB), sob orientação do Prof. Dr. Guilherme Scotti Rodrigues.

Brasília, de de 2016.

\section{BANCA EXAMINADORA:}

Prof. Dr. Guilherme Scotti Rodrigues (orientador)

Faculdade de Direito da Universidade de Brasília (FD/UnB)

Prof $^{a}$. Dra ${ }^{a}$. Flávia Milena Biroli Tokarski (membro externo) Instituto de Ciência Política da Universidade de Brasília (IPOL/UnB)

Prof. Dr. Evandro Charles Piza Duarte (membro interno)

Faculdade de Direito da Universidade de Brasília (FD/UnB)

Prof. Dr. Menelick de Carvalho Netto (suplente) Faculdade de Direito da Universidade de Brasília (FD/UnB) 
Àquele passarinho... 


\section{RESUMO}

Políticas públicas de combate à homofobia nas escolas são políticas adequadas ao nosso sistema constitucional compreendido em sua integridade, ao levar-se em conta o entendimento de direitos fundamentais como proteções essenciais das minorias com relações aos interesses, objetivos e valores das maiorias, e a articulação tensionada e complexa entre os princípios constitucionais que regem nossa comunidade política. Cada criança e adolescente que frequenta as escolas públicas possui um direito individual subjetivo a uma educação para a diferença, a uma educação que seja plural, emancipatória e igualitária, que se guie pelos princípios da liberdade identitária e da igualdade como diferença, isto é: cada estudante tem o direito de ter sua autonomia pessoal protegida de eventuais coações, de desenvolver livremente sua personalidade e sua identidade (incluindo-se sua identidade sexual) e de ser consequentemente tratada com igual consideração e respeito em razão dessa identidade. Por promoverem direitos de liberdade e de não-discriminação, políticas públicas de combate à homofobia nas escolas são exigências constitucionais que devem reger a atuação pública de todas as instituições do Estado. Em nível individual, cada cidadã que se serve da escola tem o direito individual subjetivo a obter reparação ou outra atitude protetiva quando tiver sua igual dignidade ferida com base em uma discriminação homofóbica, inclusive sendo-lhe facultado cobrar judicialmente uma postura reparatória por parte do Estado através de uma intervenção judicial. Em nível coletivo, não obstante a coletividade das sexualidades oprimidas não possa pleitear judicialmente a elaboração e efetivação de políticas públicas que assegurem seus direitos, podem legitimamente pleitear o mesmo por meio de reivindicações públicas que busquem persuadir e pressionar os órgãos legislativos e executivos a cumprirem o mandado constitucional de não-discriminação com base em orientação sexual mediante a implementação de eficientes políticas de direitos. E as políticas que apresentaremos aqui, embora não tenham até então obtido um grau significativo de sucesso prático, sinalizam a preocupação de alguns setores da sociedade civil e do Estado com os males causados pela violência homofóbica.

Palavras-chave: Homofobia e políticas públicas; Homofobia na escola; Direito como integridade; Liberdade identitária; Igualdade como diferença. 


\begin{abstract}
Public policies against homophobia in schools are appropriate policies to our constitutional system understood in its integrity, when taking into account the understanding of rights as essential protections of minorities in relation to the interests, aims and values of the majorities, and the tensioned and complex joint among the constitutional principles that govern our political community. Every child and teenager who attends public schools has an individual legal right to education for difference, to an education that is plural, emancipatory and egalitarian, which is guided by the principles of identitary liberty and equality as difference, it is: each student has the right to have her personal autonomy protected from any constraints, to freely develop her personality and identity (including her sexual identity) and therefore be treated with equal concern and respect because of that identity. For promoting rights of freedom and non-discrimination, public policies against homophobia in schools are constitutional requirements that must govern public activities of all institutions of the State. At individual level, each citizen served by the school has the individual legal right to obtain compensations or other protective attitude when having her equal dignity injured on the basis of a homophobic discrimination, and she may even claim judicially a compensatory approach by the State through judicial intervention. At collective level, nevertheless the collectivity of oppressed sexualities cannot claim judicially both the preparation and execution of public policies that assure their rights, they may legitimately claim the same through public manifestations that aim to persuade and pressure legislative and executive branches to fulfill the constitutional obligation of non-discrimination on the basis of sexual identity by the means of the execution of effective rights policies. And the policies we shall introduce here, although they have not so far achieved a significant degree of practical success, they sign the concern of some sectors of civil society and government with the injuries caused by homophobic violence.
\end{abstract}

Keywords: Homophobia and public policies; Homophobia in schools; Law as integrity; Identitary liberty; Equality as difference. 


\section{SUMÁRIO}

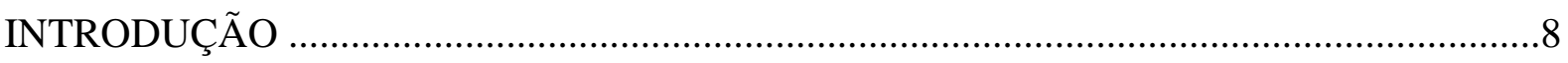

CAPÍTULO 1 - POLÍTICAS PÚBLICAS DE COMBATE À HOMOFOBIA NAS ESCOLAS: uma apresentação e algumas reflexões ...............................................................14

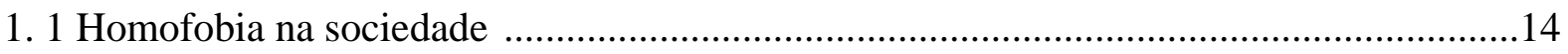

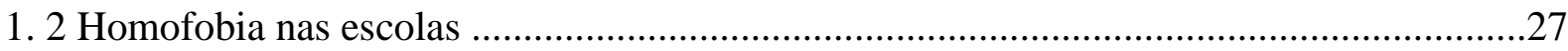

1. 3 Homofobia e políticas públicas .........................................................................................34

1.3.1 Programa Brasil Sem Homofobia (PBSH- 2004) .......................................................38

1.3.2 Educação inclusiva no Brasil e diversidade sexual ........................................................41

1.3.3 Projeto Escola Sem Homofobia (PESH - 2011) ……………………………………....49

1.4 Repercussão das políticas na esfera pública: argumentos de defesa e de ataque ................54

CAPÍTULO 2 - POLÍTICAS PÚBLICAS DE COMBATE À HOMOFOBIA NAS ESCOLAS À LUZ DA TEORIA CONSTITUCIONAL: a teoria dos direitos ........................66

2.1 A relação entre constituição e política ............................................................................66

2.2. O caráter contramajoritário dos direitos fundamentais .......................................................

2.3. Leitura moral da Constituição e direito como integridade ...................................................89

CAPÍTULO 3 - POLÍTICAS PÚBLICAS DE COMBATE À HOMOFOBIA NAS ESCOLAS E A LEITURA DOS PRINCÍPIOS SOB O PARADIGMA DO ESTADO DEMOCRÁTICO DE DIREITO E SOB A IDENTIDADE CONSTITUCIONAL BRASILEIRA: os princípios da liberdade identitária e da igualdade como diferença ............97

3.1. Direito à educação entre o público e o privado …………………………………….......102

3.2. Direito à educação e o princípio da liberdade identitária …………………………….......111

3.2.1 Excurso sobre o conceito de identidade ………………..............................................114

3.2.2 Liberdade identitária e a moralidade convencional ....................................................121

3.3 Direito à educação e o princípio da igualdade como diferença .........................................124

3.4 O princípio da liberdade identitária e o princípio da igualdade como diferença na

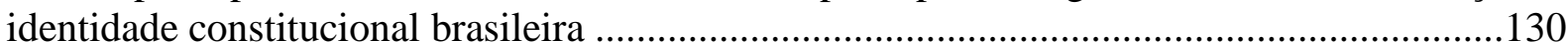

CONSIDERAÇÕES FINAIS - POLÍTICAS PÚBLICAS DE COMBATE À HOMOFOBIA NAS ESCOLAS E O SISTEMA CONSTITUCIONAL BRASILEIRO: o direito à educação para a diferença e a função da educação ...........................................................................137

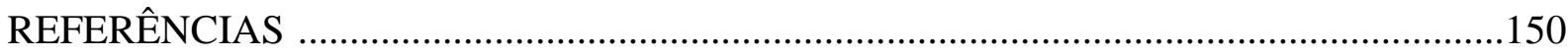




\section{INTRODUÇÃO}

Podem as sexualidades oprimidas ${ }^{1}$ reivindicar um tratamento jurídico diferenciado com base no princípio constitucional da igualdade? Podem exigir do Estado a promoção de políticas públicas de conscientização sobre a diversidade sexual, de erradicação ou minoração da homofobia e contra a discriminação baseada em orientação sexual? Em caso afirmativo, o Estado não estaria violando a igualdade de $\operatorname{todas}^{2}$ perante a lei e abdicando do pressuposto da neutralidade em prol de um grupo específico? Ou, ainda, não seria razoável objetar que, se por um lado as "minorias sexuais" têm direito ao respeito de sua identidade, por outro lado as famílias que defendem valores conservadores têm o direito de educar suas filhas e seus filhos segundo princípios, eventualmente discriminatórios, escolhidos numa esfera privada familiar?

Políticas de combate à homofobia nas escolas tocam em questões constitucionais fundamentais e engendram uma reflexão crítica sobre o modo como temos compreendido (e queremos ou acreditamos dever compreender) os princípios constitucionais fundamentais de nossa comunidade política. Justamente em virtude de seu caráter reflexivo e, portanto, potencialmente desestabilizador e subversivo, são opções políticas arriscadas e sujeitas a contundentes e apaixonados ataques quando submetidas ao escrutínio público. No entanto, tais políticas são uma mera opção de governo (uma questão de política) ou, pelo contrário, são um programa de Estado justificado e, por conseguinte, exigível por um direito fundamental (uma questão de princípio)? Se considerarmos afirmativa a resposta à última pergunta, certamente essas políticas estariam ligadas intimamente às possibilidades de aquisição e manutenção da dignidade de indivíduos pertencentes a certos grupos sociais, os quais lutam pelo respeito e pelo reconhecimento do valor tanto de suas opções individuais quanto do contexto do mundo da vida onde desenvolvem sua identidade e sua personalidade.

Afinal, conceitos-chave para o direito, como igualdade, identidade, diferença, imparcialidade, reconhecimento, justiça, equidade, liberdade, eticidade, moralidade e dignidade podem ser, a partir dessa questão, altamente articulados e problematizados.

\footnotetext{
${ }^{1}$ Escolhemos o termo "sexualidades oprimidas" por ser abrangente de todas formas possíveis de manifestação da sexualidade contrastantes com o padrão heteronormativo, e inclusive nas suas interseções com gênero e sexo, e ao mesmo tempo para evitar o uso reiterado de termos como "identidades" e "minorias", que podem conduzir ora a uma visão da sexualidade como unidade, logo excluindo eventuais diferenças não nomeadas verbalmente, ora a uma errônea noção de impotência desses grupos.

${ }_{2}^{2}$ Quanto à linguagem, optamos por utilizar a universalização dos plurais, sempre que possível, no gênero feminino. Tal universalização causa um estranhamento, e entendemos que essa estranheza cumpre exatamente o papel deste recurso: chamar a atenção para o modo como as hierarquias de gênero estão imiscuídas em nossa linguagem cotidiana. Não seria de outro modo coerente com nosso propósito crítico e transformativo seguirmos a tradição de tratar o sujeito masculino como o sujeito universal, neutro e total.
} 
Políticas desse tipo violam a igualdade e a autonomia individual ao objetivarem promover o reconhecimento de certos grupos sociais? Isto é, deve-se resolver em favor de supostos direitos coletivos das sexualidades oprimidas de postular o respeito à sua sexualidade, ou dos direitos individuais dos pais e das mães de educarem seus filhos e suas filhas segundo sua própria moral sexual, desenvolvida no espaço privado? Ou, por outro lado, deve-se privilegiar direitos individuais das crianças e adolescentes a terem liberdade de desenvolver sem constrangimentos sua identidade pessoal e receberem o correspondente igual tratamento de sua identidade sexual, ou supostos direitos coletivos das famílias de manterem intactas as tradições que prefiram cultivar? Essa discussão pode ser corretamente apresentada em termos de uma concorrência entre direitos coletivos e direitos individuais, como superficialmente poderia parecer?

Parece-nos que esse debate evoca como questão de fundo as próprias possiblidades e os limites do direito como articulador da eticidade reflexiva e transformador do estatuto do universo simbólico-cultural majoritário em prol do reconhecimento da igual dignidade das minorias. O direito é capaz de alterar uma cultura de exclusão? Esperamos no mínimo refletir acerca dessas interrogações/ provocações no decorrer deste trabalho, isentos da pretensão de solucioná-las de uma vez por todas: a própria natureza do regime democrático impulsiona o debate público cotidiano e irrestrito em direção a questões que afetam nossas formas de vida e compreensões de mundo.

Argumentaremos que políticas públicas de combate à homofobia nas escolas são programas adequados ao nosso sistema constitucional compreendido em sua integridade, ao levar-se em conta o entendimento de direitos fundamentais como proteções essenciais das minorias frente aos interesses, objetivos e valores das maiorias, e a articulação tensionada e complexa entre os princípios constitucionais que regem nossa comunidade política. Cada criança e adolescente que frequenta as escolas públicas possui um direito individual subjetivo a uma educação para a diferença, a uma educação que seja plural, emancipatória e igualitária, que se guie pelos princípios da liberdade identitária e da igualdade como diferença, isto é: cada estudante tem o direito de ter sua autonomia pessoal protegida de eventuais coações, de desenvolver livremente sua personalidade e sua identidade (incluindo-se sua identidade sexual) e de ser consequentemente tratada com igual consideração e respeito em razão dessa identidade. 
Por promoverem direitos de liberdade e de não-discriminação, políticas públicas de combate à homofobia nas escolas são exigências constitucionais que devem reger a atuação pública de todas as instituições do Estado. Em nível individual, cada cidadã que se serve da escola tem o direito individual subjetivo a obter reparação ou outra atitude protetiva quando tiver sua igual dignidade ferida com base em uma discriminação homofóbica, inclusive sendolhe facultado cobrar judicialmente uma postura reparatória por parte do Estado através de uma intervenção judicial. Em nível coletivo, não obstante a coletividade das sexualidades oprimidas não possa pleitear judicialmente a elaboração e efetivação de políticas públicas que assegurem seus direitos, podem legitimamente pleitear o mesmo por meio de reivindicações públicas que busquem persuadir e pressionar os órgãos legislativos e executivos a cumprirem o mandado constitucional de não-discriminação com base em orientação sexual mediante a implementação de eficientes políticas de direitos. E as políticas que apresentaremos aqui, embora não tenham até então obtido um grau significativo de sucesso prático, sinalizam a preocupação de alguns setores da sociedade civil e do Estado com os males causados pela violência homofóbica. Nossos argumentos serão divididos conforme o seguinte roteiro.

Primeiramente (Capítulo 1), apresentaremos as políticas públicas de combate à homofobia nas escolas que foram arquitetadas pelo Governo Federal até o momento e realizaremos algumas reflexões preliminares acerca delas. Será discutido o conceito de homofobia e considerada sua utilidade para a análise da violência cometida contra sexualidades oprimidas nas escolas (seção 1.2) e na sociedade em geral (seção 1.1), incluindo-se a apresentação de dados estatísticos sobre violência homofóbica. Em seguida, examinaremos como as políticas públicas têm articulado o conceito de homofobia e dele se servido para se justificarem e nortearem, quais direitos elas têm alegado promover e quais suas principais características e elementos (seção 1.3). Examinaremos também argumentos de defesa e de ataque dessas políticas, veiculados pela opinião pública, e em que medida eles se reportam a concepções de direitos ou de políticas (seção 1.4).

Em segundo lugar (Capítulo 2), exporemos a teoria dos direitos à qual nos fíliamos, com ênfase nas reflexões de Ronald Dworkin sobre o caráter contramajoritário da democracia constitucional (seção 2.1) e dos direitos fundamentais (seção 2.2) e sobre a tarefa interpretativa das autoridades judiciais ao ler moralmente a Constituição com base no ideal da integridade (seção 2.3). De acordo com nossa compreensão, a democracia constitucional é mais que a mera vontade da maioria, pois a vontade popular deve se sujeitar às restrições constitucionais que vinculam a política ao respeito dos direitos fundamentais das minorias. 
Em uma democracia constitucional, os direitos ocupam um valor posicional central: são proteções das minorias frente a potencial tirania da maioria, são garantias de que seus interesses fundamentais não serão anulados por uma política despótica. Questões baseadas em direitos (questões de princípio) são primordiais em relação a questões baseadas no bem-estar coletivo (questões de política), à medida que aquelas promovem a dignidade, a igualdade e a liberdade de cada indivíduo em particular, mesmo quando essa promoção em tese deixa a coletividade insatisfeita. Os direitos fundamentais são princípios com conteúdo moral cuja interpretação demanda das juízas uma criteriosa análise da teoria política subjacente ao sistema jurídico adotado: quais são os princípios de justiça que essa teoria política pressupõe, como podem ser lidos de forma coerente e íntegra tendo em vista a história institucional e as exigências atuais de justiça em uma sociedade dinâmica e complexa? Ressaltamos que políticas de combate à homofobia nas escolas são questões de princípio que - em uma democracia regida por uma constituição que prevê a liberdade e a igualdade de direitos de cada cidadã e cidadão - devem ser pensadas e implementadas mesmo contra a vontade das maiorias políticas, tal com assim exige nossa Constituição em sua integridade.

Logo adiante (Capítulo 3), demonstraremos que a Constituição Federal de 1988 - base jurídica e política de nosso compromisso com o Estado democrático de direito - consagra os princípios da liberdade identitária (seção 3.2) e da igualdade como diferença (seção 3.3). $\mathrm{O}$ paradigma do Estado democrático de direito inaugura uma renovada compreensão dos princípios da liberdade, da igualdade, da propriedade, da democracia e da separação entre esferas pública e privada. As políticas públicas de combate à homofobia nas escolas se coadunam com o atual paradigma constitucional e se acomodam em nossa identidade constitucional, como se depreende da análise dos argumentos das ministras e dos ministros do Supremo Tribunal Federal ao julgarem ação direita de inconstitucionalidade que avaliava a constitucionalidade da união civil entre pessoas do mesmo sexo (seção 3.4). Além disso, o combate à homofobia e a tematização dos preconceitos de gênero e sexualidade são questões públicas elementares que devem deixar o confinamento do espaço privado familiar e chegar ao âmbito da discussão pública em uma esfera política plural e marcada pela diversidade social e cultural (seção 3.1).

Finalmente (Considerações Finais), defenderemos a ideia de que o direito à educação para a diferença - a uma educação plural, emancipatória e igualitária - decorre da comunidade de princípios criada por nossa Constituição. Tal direito à educação para a diferença - de duplo aspecto individual e coletivo, jurídico e político -, titularizado por todas 
as estudantes submetidas ao sistema educacional, fundamenta a adoção de políticas de combate à homofobia nas escolas; e essas políticas públicas, tal como as introduzimos, são adequadas para lidar com o problema da homofobia sob o pressuposto de que promovem o direito à educação para a diferença. São políticas de reconhecimento transformativas que incorporam uma perspectiva política de tratamento da diversidade sexual, à medida que buscam desocultar as relações de poder que instituem hierarquias entre as sexualidades heterossexual e não-heterossexual, se propõem problematizar e colocar em xeque a heteronormatividade e ambicionam criar condições para o livre autodesenvolvimento identitário-sexual dos sujeitos escolares com base em sua autonomia pública e privada.

Uma breve advertência metodológica: utilizamos, neste trabalho, teorias sociológicas, antropológicas, políticas e jurídicas derivadas de tradições epistemológicas distintas e, à primeira vista, conflitantes entre si. Ao mesmo tempo em que analisamos o fenômeno da homofobia e da formação de identidades (sexuais) com o auxílio de teorias pós-estruturalistas (de autoras como Michel Foucault, Judith Butler, Jeffrey Weeks, Guacira Lópes Louro, Stuart Hall, Nancy Fraser...), também buscamos conciliá-las, na medida do possível, com uma abordagem de teorias políticas e jurídicas liberais ou liberal-republicanas (de autoras como Ronald Dworkin, Jürgen Habermas, Michel Rosenfeld, Susan Okin, Jean Cohen...). Acreditamos que, embora embasadas em premissas teóricas distintas, a conciliação de tais correntes de pensamento é adequada para o tratamento da problemática proposta. As teorias liberais às quais nos referimos não se detêm exatamente sobre os processos de formação de identidades sob a perspectiva de uma consideração das relações de poder, enquanto as teorias pós-estruturalistas ou desconstrucionistas as quais mencionamos não se debruçam sobre a elaboração de uma teoria da política ou do direito reconstrutiva do ponto de vista interno do participante. Ambas as perspectivas, unilateralmente consideradas, são inadequadas para captar o problema da homofobia em sua amplitude e os modos de lidar com a homofobia no marco de um Estado constitucional estruturado por instituições jurídicas. Por isso julgamos adequado articulá-las nos debates que exigem, ao mesmo tempo, um ponto de vista crítico com relação ao fenômeno do poder social e um ponto de vista reconstrutivo com relação à compreensão dos problemas básicos da teoria do direito e das instituições do Estado de direito. Em última análise, a luta pela liberdade identitária é uma luta liberal pela defesa da autonomia privada em contraposição aos poderes sociais e coletivos. Nossa perspectiva é então uma perspectiva liberal crítica: não marcada pelo conformismo do liberalismo clássico 
ao abordar de uma maneira neutralizada o problema do poder, mas ainda assim comprometida com as demandas liberais seculares pelo aumento da liberdade e da igualdade dos indivíduos. 


\section{CAPítulo 1 - POLÍticas PÚBlicas de COMBATE À HOMOFOBia NAS ESCOLAS: uma apresentação e algumas reflexões}

Tramitou no Congresso Nacional, entre 2006 e 2014, o Projeto de Lei da Câmara ${ }^{\circ}$ 122/2006 (PLC 122/06), de autoria da então deputada federal Iara Bernardi (PT/SP), cujo escopo consistia em alterar a Lei $\mathrm{n}^{\mathrm{o}} 7716$, de janeiro de 1989 - que define os crimes resultantes de preconceito de raça ou de cor - e o $\S 3^{\circ}$ do art. 140 do Decreto-Lei $n^{\circ} 2848$, de 7 de dezembro de 1940 (Código Penal) - que define o tipo penal específico de injúria racial -, a fim de estender seu rol de condutas tipificadas e punir a discriminação e o preconceito ${ }^{3}$ de gênero, sexo, orientação sexual ou identidade de gênero. ${ }^{4}$ Embora não tenha chegado a ser promulgada $^{5}$ e convertida em lei, tal iniciativa demonstra uma preocupação de setores da vida política institucional, em resposta às pressões de agentes da sociedade civil, acerca do preconceito e da discriminação com base em identidades sexual e de gênero disseminadas pela sociedade, além de evidências de seu reconhecimento enquanto problemática social de grande relevância. Batizada de "Lei da Homofobia", há, por parte dos discursos tanto especializados quanto leigos a respeito do projeto de lei, menção expressa ao conceito de homofobia, nomenclatura que incorporaria de modo genérico a hostilização a homossexuais, bissexuais, travestis e transgêneros e passaria a gozar de status jurídico.

\section{1 Homofobia na sociedade}

\footnotetext{
${ }^{3}$ Ainda que preconceito e discriminação sejam categorias inter-relacionadas, é possível dizer, grosso modo, que aquele trata de percepções mentais negativas em face de indivíduos pelo simples fato de eles pertencerem a grupos submetidos a representações sociais subvalorizadas, enquanto esta é a concretização, no plano das relações sociais, das atitudes sociais relacionadas ao preconceito, de modo a atingir a esfera de direitos de suas vítimas. Sobre as diversas abordagens do preconceito e da discriminação, conferir RIOS (2009, pp. 54-59). No entanto, o limiar entre um e outro é bastante tênue, e os conceitos referem-se um ao outro de maneira circular: uma discriminação quase sempre é precedida de um preconceito, e um preconceito pode se originar de práticas de discriminação cristalizadas e generalizadas socialmente.

${ }^{4}$ Conforme o art. $1^{\circ}$ do PLC, a ementa da Lei $n^{\circ} 7716$ passaria a vigorar com a seguinte redação: "Define os crimes resultantes de discriminação ou preconceito de raça, cor, etnia, religião, origem, condição de pessoa idosa ou com deficiência, gênero, sexo, orientação sexual ou identidade de gênero".

5 O PLC 122/06 encontrava-se na Comissão de Direitos Humanos do Senado Federal, sob relatoria da então senadora Marta Suplicy (PT/SP), quando foi arquivado em 16/12/2014, em obediência ao art. 332 do Regimento Interno do Senado Federal (RISF), que determina sejam arquivadas todas as proposições em tramitação ao final da legislatura, sendo automaticamente arquivadas aquelas que se encontrem tramitando há duas legislaturas, "salvo se requerida a continuidade de sua tramitação por $1 / 3$ dos Senadores, até 60 (sessenta) dias após o início da primeira sessão legislativa da legislatura seguinte ao arquivamento, e aprovado o seu desarquivamento pelo Plenário do Senado" (art. 332,§ 1º - RISF). Desde 19/02/2015, encontra-se na Secretaria de Arquivo. Fonte: Sítio eletrônico do Senado Federal: http://www25.senado.leg.br/web/atividade/materias/-/materia/79604. Acessado em 08/10/2015.
} 
A homofobia refere-se a uma variedade de fenômenos tão complexa quanto é imprecisa e contestável ${ }^{6}$ sua utilização terminológica, seja na literatura sociológica, antropológica ou psicológica especializada, seja na linguagem corrente do dia-a-dia. Empregado pela primeira vez no discurso acadêmico, de forma conspícua, na pesquisa do psicólogo clínico estadunidense George Weinberg em 1972, definido como o medo de estar próximo a pessoas homossexuais, o termo homofobia, neologismo etimologicamente sublimado a partir da justaposição de dois radicais gregos - homo e fobia, respectivamente designando "semelhante" e "temor, medo" - inicialmente estava ligado a estudos de caráter medicalizante a respeito da experiência homossexual masculina. Gradativamente, o conceito passou a acolher em seu alcance sentimentos e atitudes negativas variadas, tais como aversão, desprezo, desconfiança, desconforto, medo, repulsa ou ódio generalizado em relação a pessoas, práticas e modos de vida tidos como homossexuais ${ }^{7}$ (JUNQUEIRA, 2009, p. 370; RIOS, 2009, p. 60; BRASIL, 2011a, p. 34; BRASIL, 2011b, pp. 7, 8). A adaptação de sua abrangência semântica passou por pelo menos duas etapas compreensivas: de uma (a) compreensão psicológica a uma (b) compreensão sociológica, de modo que, frisemos, ambas as dimensões interpretativas da homofobia não se excluem mutuamente, antes colaboram para o entendimento do fenômeno homofóbico em toda extensão de sua complexidade.

(a) Inicialmente a homofobia foi vislumbrada em sua dimensão subjetiva de aversão fóbica com embasamento nas abordagens psicológicas concernentes ao estudo do medo, da rejeição, do ódio, da evitação e do desprezo a homossexuais. Trata-se de um discurso clínico,

\footnotetext{
${ }^{6}$ Alguns termos são propostos com o intuito de romper com abordagens centradas na fobia: homopreconceito, heterocentrismo, heterossexismo, homonegatividade etc. (JUNQUEIRA, 2009, p. 372). Embora a palavra homofobia, uma vez lida em termos literais, exclua as identidades bissexual, transgênero e travesti e a princípio corrobore o binarismo supostamente inescapável homossexualidade/ heterossexualidade, e portanto reafirme a taxatividade das complexas manifestações sexuais - postura teórica que, como se verá, justamente pretendemos criticar -, manteremos seu uso conceitual ampliado na medida em que é diuturnamente divulgada na literatura, especialmente jurídica, sobre sexualidade e discriminação. Não obstante, reconhecemos a maior acurácia do termo "heterossexismo", que se mostra mais abrangente e traz implícito em sua estrutura morfológica as causas e raízes discriminatórias, ao qual nos reportaremos frequentemente, quando julgarmos mais pertinente.

${ }^{7}$ Ressalte-se que a atribuição da identidade homossexual como uma característica supostamente fixa e imanente à personalidade de certos indivíduos é um processo cujo momento conclusivo é relativamente recente. Segundo a arqueologia da história da sexualidade elaborada por Michel FOUCAULT (1988), a gênese da identidade homossexual - assim como, por contraposição, da heterossexual - resultou de um processo de controle e assujeitamento de indivíduos: a homossexualidade deixou de ser um desvio acidental exterior, sinalizado pela prática da sodomia, para tornar-se uma "espécie de androginia interior, um hermafroditismo da alma". Até o século XIX, relações sexuais entre pessoas do mesmo sexo biológico eram vistas como um erro ou um pecado potencialmente cometido por qualquer pessoa. Unicamente a partir daí é o que o homossexual torna-se uma espécie, um tipo distintivo de identidade pessoal. Como sintetiza de forma brilhante Jeffrey WEEKS (2000, p. 73), "antes do século XIX a 'homossexualidade' existia, mas o/a 'homossexual' não". Aprofundar-nos-emos neste tema no Capítulo 3, oportunidade em que discutiremos mais a fundo a questão das identidades sociais. Apenas nos lembremos de que Foucault não se refere em momento algum ao conceito de identidade, mas parece estar lidando com a problemática inaugurada por esse conceito a todo tempo (HALL, 2003, p. 120).
} 
tributário da Sexologia e de seus pressupostos pseudocientíficos ${ }^{8}$ carregados de considerações de ordem moral, religiosa e ética compartilhadas pelos grupos hegemônicos da sociedade tendo em vista seu contexto temporal e o arranjo específico da teia de relações de poderes sociais. O discurso científico sobre sexualidade daquela época trata, em verdade, de enunciações aparentemente laicas (homofobia secular), ${ }^{9}$ ou pelo menos não declaradamente religiosas, revestidas do caráter de representações, juízos e práticas científicas a fim de legitimar o status de normalidade de uma forma particular de experiência da sexualidade humana e assegurar que as fronteiras do sexo continuarão intransponíveis através "da ameaça da psicose, da abjeção e da impossibilidade psíquica de viver” (BUTLER, 2000, p. 168).

Tanto é que houve, nesse período, a divulgação de mais de setenta diferentes teorias sobre as causas da homossexualidade. A busca de uma causa biológica, genética, hormonal ou psíquica relaciona-se com o esforço pelo desenvolvimento de curas da prática homoerótica, tida até aquele momento como um desvio patológico ${ }^{10}$ o próprio vocabulário corrente na área da saúde evocava o sufixo "-ismo" incorporado a termos como "homossexualismo", "travestismo" e "transexualismo", que transparecem marcas profundas da tendência à patologização. Prova de que os estudos causais são marcados axiológica e ideologicamente é que semelhantes esforços nunca foram destinados a desvendar a origem do

\footnotetext{
8 A Sexologia surgiu no final do século XIX como disciplina autônoma tomando por base a Psicologia, a Biologia, a Antropologia, bem como a História e a Sociologia (WEEKS, 2000, p. 39). A invenção da Sexologia faz parte de artefatos regulatórios dos corpos no contexto da emergência de uma sociedade disciplinar no sentido foucaultiano, em que o discurso científico adquire papel central na formação e controle da reprodução de identidades. Com a publicação de Psychopathia Sexualis, de Krafft-Ebing, o "discurso do pervertido" foi traduzido em termos teóricos tratando o controle dos "desvios sexuais" como um problema social emergente: "Biologia e Medicina são chamadas para a exploração meticulosa dos corpos e da espécie, passando rapidamente da descrição para a prescrição" (ALMEIDA, 2003, p. 5).

9 As raízes discursivas da homofobia tanto podem provir de instituições, cosmovisões e práticas religiosas, quanto de retóricas laicas, tais como a "homofobia antropológica", a "homofobia liberal", a "homofobia stalinista" e a "homofobia nazista". A primeira, por acreditar que a evolução das sociedades conduz inevitavelmente aos arranjos de conjugalidade heterossexual, credita à homossexualidade o risco de desintegração social e civilizacional. A segunda, por considerar a sexualidade matéria estritamente privada, não provê proteção jurídica no espaço público aos homossexuais. A terceira condenou a prática homossexual por ser um indício da decadência moral das sociedades capitalistas. A quarta condenou à morte na prisão pelo menos 500.000 homossexuais no afã de "purificação da raça ariana" (RIOS, 2009, p. 63). (Para um comentário sobre a homofobia nos regimes stalinista e nazista, conferir FRY, MacRAE (1985, pp. 89-91).

10 Três fatos alteraram definitivamente a classificação da "homossexualidade" como doença. No Brasil, o Conselho Federal de Medicina transferiu a homossexualidade da categoria de "desvios e transtornos sexuais" para "outras circunstâncias psicossociais" desde 1985. Em 17 de maio de 1990 (data hoje considerada o Dia Internacional do Combate à Homofobia), a 43 ${ }^{\mathrm{a}}$ Assembleia Geral da Organização Mundial de Saúde retirou a homossexualidade da Classificação Internacional de Doenças, mandamento que entrou em vigor em todos os países-membros das Nações Unidas em 1993, inclusive no Brasil. Em 1999, o Conselho Federal de Psicologia pátrio baixou a Resolução $\mathrm{n}^{\circ} 1$, proibindo profissionais da área de empreender qualquer ação que trate a homossexualidade como doença. Essas três decisões extirpam qualquer dúvida sobre um possível caráter patológico da homossexualidade, embora, com frequência, esse discurso reapareça no senso comum e mesmo em produções científicas ideologicamente enviesadas e mal intencionadas.
} 
comportamento heterossexual, este então tratando-se de um verdadeiro axioma naturalmente evidente.

(b) Desde uma outra perspectiva, estudiosas adotam um posicionamento sociológico que recusa as acepções patologizantes e definem a homofobia como fenômeno social (homofobia social) atravessado por situações e mecanismos sociais que a originam e a condicionam. Há uma transferência $d a$ ênfase analítica nos modelos explicativos centrados no âmbito microindividual para uma reflexão crítica de viés macroestrutural a respeito dos comportamentos socialmente reiterados e situações recorrentes que favorecem a homofobia, infiltradas nos campos cultural, educacional, social, familiar, político, institucional e jurídico. Mais que produto de reações anti-homossexuais isoladas com efeitos privados pontuais, a homofobia adquire a carga de fator público de restrição de direitos de cidadania, agindo mediante o bloqueio do acesso integral à educação, à saúde, ao trabalho, à segurança e ao gozo não constrangido dos típicos direitos liberais de liberdade individual e de igualdade de tratamento. Passa-se a concebê-la a partir de:

reflexões sobre as relações de poder e os processos de produção de diferenças culturais, em que se examinam e se assinalam os indissociáveis vínculos entre homofobia e processos de construção de padrões relacionais, preconceitos e mecanismos discriminatórios relativos a questões de gênero e à dominação masculina (JUNQUEIRA, 2009, p. 373).

Tais mecanismos consistem na deterioração identitária daquelas pessoas associadas ao universo simbólico homossexual mediante a construção de estereótipos e estigmas que lhes incutem um gênero distorcido, defeituoso, abjeto, ou simplesmente lhes impõem a perda do gênero, de modo que um homem ou uma mulher praticantes de atividades homoeróticas perderiam sua autenticidade enquanto tais. Essa chave de leitura conecta o conceito de homofobia ao conceito de heterossexismo.

O conceito de heterossexismo mostra-se mais sensível para a inclusão das identidades desviantes do padrão heteronormativo e para tratar da discriminação experimentada não só por homossexuais, mas por todas aquelas que desafiam o parâmetro de normalidade heterossexual, as quais passaremos a chamar de sexualidades oprimidas. Nas palavras de Roger Raupp RIOS (2009, p. 62), a ideia de heterossexismo designa: 
organizações burocráticas, tais como a linguagem e o sistema jurídico. Daí advém, de um lado, superioridade e privilégios a todos que se adequam a tal parâmetro e de outro, opressão e prejuízos a lésbicas, gays, bissexuais, travestis, transexuais e até mesmo a heterossexuais que porventura se afastem do padrão de heterossexualidade imposto.

De um ponto de vista sociológico, poderíamos afirmar que o heterossexismo, a visão da supremacia das heterossexuais e a instituição de seu modo de vida e de experimentação dos desejos como única possibilidade legítima - posto que supostamente natural - de expressão identitária sexual, é a causa e principal concepção ideológica e moral motriz da homofobia enquanto manifestação social. A afirmação heterossexista acarreta necessariamente a negação da não heterossexual e seu confinamento ao segundo plano da vida social ou simplesmente seu completo alijamento, quando não a punição moral ou criminal. ${ }^{11}$ Com efeito, a classificação binária homossexuais/ heterossexuais implicou o privilégio destas ao preço da opressão e do desfavorecimento daquelas. ${ }^{12}$ Deste modo, heterossexismo e homofobia são duas faces do mesmo problema (LOURO, 2009, p. 89).

O heterossexismo funciona e obtém sustentação por meio de um dispositivo que alinha inexoravelmente as categorias sexo, gênero e sexualidade, ${ }^{13}$ assentando que,

\footnotetext{
${ }^{11}$ Segundo relatório anual da ILGA (International Lesbian, Gay, Bisexual, Trans and Intersex Association) para o ano de 2015, a prática homossexual ainda é criminalizada em 80 países (sendo 36 na África, 25 na Ásia, 11 na América Latina e Caribe e 8 na Oceania). Fonte: International Lesbian, Gay, Bisexual, Trans and Intersex Association: Carroll, A. \& Itaborahy, L.P. State Sponsored Homophobia 2015: A world survey of laws: criminalisation, protection and recognition of same-sex love (Geneva; ILGA, May 2015). Disponível em: http://ilga.org/what-we-do/state-sponsored-homophobia-report/. Acessado em: 11/11/2015. Percebemos então que em praticamente todo o mundo ocidental e em quase todos os países do Hemisfério Norte as relações entre pessoas do mesmo sexo foram sendo progressivamente descriminalizadas. Tal atitude do sistema penal ainda se mantém, na maior parte, em países africanos e asiáticos subdesenvolvidos. Os dados nos chamam atenção para uma possível relação entre subdesenvolvimento e criminalização de práticas homoeróticas, sugerindo que em países onde há uma cultura mais democrática e maior acesso à educação de sua população tende-se a legalizar a homossexualidade ou, no mínimo, retirá-la do rol de condutas criminosas.

12 Isso significa que, no nível social, aquelas pessoas conformadas ao padrão heterossexual desfrutam mais facilmente, ou até presumidamente, de reconhecimento de sua dignidade e de opiniões positivas a respeito de seus atributos, características e contribuições pessoais; no nível político, que seu acesso à representatividade por parte das instituições é consideravelmente mais alto, tanto pela circunstância de que suas perspectivas sociais estão incorporadas em uma difusa moralidade coletiva, quanto pelo maior número de representantes políticos heterossexuais com condições de elegerem-se a cargos públicos, uma vez ausente o empecilho do preconceito de orientação sexual; no nível econômico, que a distribuição de bens materiais e o acesso a oportunidades das não heterossexuais pode ser prejudicado, principalmente pelas barreiras na aquisição de empregos por parte de determinadas identidades sociais gritantemente desviantes (sobretudo no caso de travestis e transgêneros, o desemprego ocasiona, imediatamente, maior probabilidade de permanência na pobreza) e no indevido reconhecimento da contribuição de suas atividades laborais; e finalmente, no nível jurídico, que o sistema de direitos tende a se fechar para as identidades não heterossexuais, seja no momento da elaboração de leis e políticas, seja no momento de sua execução pelas autoridades burocráticas, seja quando da apreciação judicial em casos controversos, de modo a excluir as LGBT da titularidade efetiva dos direitos de cidadania.

13 A despeito de altamente interdependentes, tais conceitos designam dimensões distintas das complexas subjetividades humanas. Podemos adiantar que a ideia de sexo remonta ao discurso científico de separação entre
} 
presumivelmente, todas as pessoas, cujo corpo é sexuado, isto é, sinalizado por determinado sexo fisiológico (a fêmea ou o macho), devem assumir um comportamento social já préfixado nos termos da experimentação de seu sexo (as fêmeas devem interiorizar o comportamento típico feminino e os machos devem interiorizar o comportamento típico masculino, com todas as adequações que tal injunção exige) e devem ter como objeto de seu desejo apenas indivíduos do sexo biológico (e que também quer dizer: do gênero) oposto. Há uma articulação rígida e unívoca entre anatomia, comportamento, desejo e identidade. A transgressão dessa tríade que compõe aquilo que chamaremos desde agora de heteronormatividade é constantemente evitada ou, em último caso, repelida ou punida, através de instituições sociais de controle. No caso do sentimento interior de atração por sujeitos do mesmo sexo biológico/ gênero, a repressão encontra guarida na ideia de pecado ou culpa moral, imbuída nos discursos religiosos ou moralistas; no caso da exteriorização desse sentimento, a repressão poderá ser prontamente executada pelas instituições sociais como a família e a escola, e até mesmo, em casos extremos, pelas instituições jurídicas, seja através da condenação de certas identidades sexuais ao submundo da criminalidade, seja privando-as, através de omissões, do acesso a bens, direitos e proteção suficiente para deixarem de viver suas vidas na penumbra da clandestinidade.

O processo de afirmação da heteronormatividade é contínuo, onipresente e por vezes sutil, quase despercebido ou imperceptível; ele habita sorrateiramente práticas sociais, culturais e pedagógicas, processos de aprendizagem, a linguagem e o arsenal de significações do universo simbólico, as práticas institucionais e o modo como o Estado desenvolve suas atividades. FOUCAULT (1988) já demonstrara como um discurso é tanto mais eficaz quanto mais ele consiga se invisibilizar na prática cotidiana, ou quanto mais as pessoas ajam

dois entes anatomicamente diferenciados - macho e fêmea - de acordo com sua genitália e demais características físicas e hormonais (ver nesse sentido WEEKS, 2000, p. 40 e ss.), embora seja forçoso reconhecer que a separação dicotômica dos sexos, datada do final do século XVIII e do início do século XIX, obedeceu mais a razões política do que científicas. Como observa Judith BUTLER (2000, p. 159), o sexo tornou-se uma espécie de fantasia instalada em um local pré-linguístico ao qual não se tem acesso direto. Distintamente podemos conceituar gênero com base em construções sociais, histórias, culturais e políticas que dizem respeito a disputas materiais e simbólicas sobre os papéis sociais a ser desempenhados pelos homens e pelas mulheres, situadas em diferentes posições hierárquicas de poder e com acesso a diferentes distribuições de recursos e oportunidades. Por sua vez, orientação sexual vai mais além de determinantes biológicas, do que puramente sexo, fazendo menção à direção e à inclinação dos desejos afetivos e eróticos. Este termo veio em substituição de "opção sexual", de modo a explicitar que o desejo afetivo/ erótico não se trata de mera opção consciente do indivíduo, mas antes é fruto de um processo extremamente complexo, contraditório e dinâmico de constituição de subjetividades, pelo qual o indivíduo passa a lidar com fatores sociais, vivenciando-os, interpretando-os, ressignificando-os ou reproduzindo-os, a partir de sua trajetória particular de vida. A produção do desejo segue determinações inconscientes. De outro modo, identidade de gênero designa o modo como alguém se autocompreende e se apresenta para os demais como masculino e feminino, como a mescla de ambos ou como nenhuma das duas categorias, independentemente de seu sexo biológico e de sua orientação sexual (SECRETARIA, 2007, pp.16, 17, 19). Voltaremos a esse ponto no decorrer da dissertação. 
motivadas por ele sem ao menos se darem conta. Contudo, é importante destacar, ainda seguindo a linha foucaultiana e sua teoria relacional do poder, ${ }^{14}$ que os discursos conformadores heteronormativistas são a todo momento desafiados por discursos divergentes e práticas subversivas da norma produzidas a partir do ponto de ação daquelas que ocupam a posição subordinada. Todo ato de poder inaugura um potencial de resistência e revolta; não há poder sem liberdade, pois, caso contrário, haveria violência. O poder é uma estratégia socialmente disputada, e não um privilégio que alguém possui, de modo que não pode ser aprisionado definitivamente (LOURO, 1997, p. 38). Como afirma Guacira Lópes LOURO (2009, p. 90), até como atestado da artificialidade, ${ }^{15}$ discursividade e impositividade dos arranjos heteronormativos:

(...) Não há nenhuma garantia de que a heterossexualidade aconteça naturalmente (se isso fosse seguro, não seriam feitos tantos esforços para afirmar e reafirmar esta forma de sexualidade). (...) A norma pode e é subvertida. Todos os dias, em todos os espaços, homens a mulheres a desafiam. Alguns sujeitos embaralham códigos de gêneros ou atravessam suas fronteiras; outros articulam de formas distintas sexogênero-sexualidade; outros ainda criticam a norma através da paródia ou da ironia. A heteronormatividade constituiu-se, portanto, num empreendimento cultural que, como qualquer outro, implica disputa política.

Gostaríamos de acrescentar algumas implicações diretas ou colaterais da heteronormatividade. Em primeiro lugar, a associação triádica heteronormativa articula as noções de gênero e sexualidade a ponto de a transgressão da heteronorma afetar simultaneamente a identidade sexual e a identidade de gênero do sujeito. É comum atribuir-se ao homem não heterossexual a perda de sua masculinidade e a assunção do gênero feminino, quando não a perda total de uma identidade de gênero, que ficaria a transitar em um espaço nebuloso. A dificuldade de separar identidade de gênero de identidade sexual faz com que os sujeitos se vejam persuadidos a incorporar compulsoriamente uma autorreferência alienante,

\footnotetext{
${ }^{14} \mathrm{O}$ poder em Foucault possui não somente aspectos negativos (de proibição, inibição, negação, impedimento), mas também positivos (de produção, induzimento, incitação de comportamentos). Em sua dimensão positiva, o poder institui, através de práticas e relações, modos de ser e de estar no mundo, formas de falar e de agir, condutas e posturas apropriadas. Conferir LOURO (1997, pp. 40-41). É o que Judith BUTLER (2000, p. 169) chama de paradoxo da subjetivação: "o sujeito que resistiria a essas normas é, ele próprio, possibilitado, quando não produzido, por essas normas".

15 Conferir também, a esse respeito, Jeffrey WEEKS (2000, p. 71): “(...) a pesquisa histórica recente tem demonstrado que não apenas outras culturas não têm essa forma de ver a sexualidade humana, como também não tinham as culturas ocidentais até mais ou menos recentemente". Weeks refere-se ao fato de os pares conceituais heterossexualidade e homossexualidade terem sido uma criação recente na cultura ocidental, datada do final do século XIX. Reportando-se à pesquisa antropológica de Mary MacIntosh (1968), Sérgio Carrara e Júlio Simões (2007, p. 82) observam que, embora comportamentos e desejos tidos como homossexuais provavelmente existam em todas as sociedades, apenas algumas produziam uma identidade homossexual específica submetida a controles e preocupações quanto ao limite do sexualmente aceitável.
} 
que não condiz necessariamente com sua autoidentificação a respeito da masculinidade e da feminilidade, mas que no mais das vezes somente obedece às expectativas sociais.

Em segundo lugar, a heteronormatividade se conecta com a misoginia (a desvalorização do feminino) e com a reafirmação dos papeis sociais derivados das hierarquias sociais de gênero (MOREIRA, 2010, pp. 54-55). É comum que os homossexuais efeminados e as transexuais sejam mais estigmatizadas, replicando-se a desigualdade de gênero e a interpelação pela superioridade do masculino, do modelo androcêntrico de macho viril. Peter FRY e Edward MacRAE (1983, pp.45, 49) notam que o grande tabu, o grande escândalo da homossexualidade é a aparente inversão de gênero que ela supõe, principalmente quando um indivíduo do sexo masculino abdica de sua virilidade e dá vazão a uma inversão: à presença de elementos femininos onde eles deveriam estar ausentes, ou à performance sexual "passiva", 16 supostamente um sinal de fraqueza e humilhação. Seguindo esse raciocínio, poderíamos chegar a uma conclusão mais radical de que a homofobia se trata de uma espécie particular de misoginia. Por essa razão, mesmo um sujeito que se defina como heterossexual pode ser acusado de homossexual caso frustre as expectativas ligadas às performatividades de gênero. E mesmo que discreta ou imperceptivelmente, a heteronormatividade constrange também os indivíduos heterossexuais que ela aparentemente favoreceria: de fato, ela produz efeitos, mesmo que distintos, sobre todos e todas. A todo tempo, todos e todas são interpeladas pelas injunções normatizantes e pelos dispositivos de vigília da sexualidade, devendo provar e reforçar sua adequação à heteronorma.

Finalmente, convém ressaltar que o preconceito e a discriminação podem ter lugar de forma direta ou indireta, comissiva ou omissiva, intencional ou acidental, explícita ou oculta, daí falar-se em diferentes modos de expressão da homofobia. Seguramente as formas indiretas, acidentais, omissivas e ocultas são mais ardilosas e difíceis de serem notadas, pois estão mascaradas sob a aparência da normalidade, da tradição, daquilo "que sempre foi", de modo a acometerem tanto indivíduos quanto instituições que rejeitam conscientemente sua prática intencional. Por isso podemos falar em homofobia cultural e homofobia institucional, na medida em que nossos símbolos e suas respectivas cargas valorativas estão imersos em um

\footnotetext{
${ }^{16}$ Note-se uma imbricação entre masculinidade/ atividade sexual e feminilidade/passividade sexual presente no imaginário social brasileiro, em particular, e ocidental em geral. A categoria "homens" englobaria todos os que mantivessem uma postura "ativa" com relação a mulheres e homens e excluiria os sexualmente "passivos", tratados como se fossem portadores de uma natureza híbrida e andrógina que embaralha características anatômicas masculinas com traços do gênero feminino (CARRARA, SIMÕES, 2007, pp. 69-70). Essa imbricação não é apenas fortuita, mas em vez disso gera uma hierarquia sexista androcêntrica que coloca o masculino no topo.
} 
contexto heterossexista em que as cosmovisões e perspectivas próprias de um grupo camufladas sob um ponto de vista genérico, neutro e imparcial - são concebidas como a normalidade social, o natural, o óbvio.

Ademais, a homofobia desfruta de uma posição peculiar se comparada a outras modalidades de preconceito e discriminação (como o racismo, o machismo, o antissemitismo), uma vez que ela é comumente praticada de forma deliberada, explícita e intencional, enquanto essas outras modalidades são comportamentos antissociais mais frequentemente reprimidos. ${ }^{17}$ Atos homofóbicos são não raro motivo de orgulho e regozijo por parte de suas praticantes, as quais recebem incentivo e aprovação social, além do benefício da impunidade. Ao hostilizar uma homossexual, a agente ao mesmo tempo executa sua função de vigilante da sexualidade alheia delegada pelos dispositivos da sexualidade e crê estar autoafirmando sua identidade normal, autoimunizando-se da possibilidade de vir a ter sua sexualidade questionada.

Práticas homofóbicas ostensivas podem transcender o nível discursivo e degenerar-se em atos de agressão não apenas verbal, como também física, chegando até lesões corporais graves e à morte de suas vítimas. Dados sobre violência homofóbica no Brasil ${ }^{18}$ mostram a extrema urgência do debate, da tematização aprofundada e do enfrentamento desse problema. Em iniciativa pioneira no Brasil e na América Latina, o Governo Federal publicou dados oficiais sistematizados sobre violência homofóbica no Brasil em 2011. Embora movimentos sociais mantivessem tal prática desde os anos 1980, utilizando-se de estatísticas

\footnotetext{
${ }^{17}$ Inclusive o direito penal brasileiro pune explicitamente o racismo (art. $5^{\circ}$, XLII - CF: "A prática do racismo constitui crime inafiançável, sujeito à pena de reclusão, nos termos da lei") e a injúria racial (art. 140, $\S 3^{\circ}$ Código Penal: "Se a injúria consiste na utilização de elementos referentes a raça, cor, etnia, religião origem ou a condição de pessoa idosa ou portadora de deficiência"). A violência contra a mulher é especialmente punida em âmbito penal pela Lei $\mathrm{n}^{\circ}$ 11340, de7 de agosto de 2006, conhecida como Lei Maria da Penha. O antissemitismo em geral não é visto como um problema emergente e genuinamente brasileiro, embora haja jurisprudência no sentido de enquadrá-lo em crime de racismo ou de injúria racial (conferir Habeas Corpus 82424 - STF); no entanto a jurisprudência internacional confere-lhe especial ênfase. Chegamos, pois, à seguinte questão: a ostensividade da homofobia deve-se à sua não repressão jurídica formal, à sua não criminalização com base em um tipo penal específico? Ou simplesmente é uma discriminação que "naturalmente" provoca mais abjeção? Se respondermos afirmativamente à primeira questão, admitiremos que o caminho do PLC 122 é correto e que os movimentos LGBT e demais comprometidos com os direitos humanos devem seguir sua luta dentro da ótica punitiva. Se respondermos afirmativamente à segunda, afirmamos a importância de políticas públicas no âmbito educacional voltadas à conscientização das raízes irracionais, perniciosas e hediondas da homofobia. Em todo caso, uma resposta não exclui a outra: ambas são caminhos possíveis que só poderão ser trilhados depois de um sério debate público.

${ }^{18}$ Entre 1963 e 2001, 2092 pessoas foram assassinadas no Brasil pelo simples fato de serem gays, lésbicas ou transgêneros. Só em 2000, foram 130 assassinatos, uma média de um crime contra LGBT a cada três dias. Isso torna o Brasil um dos países com maiores índices de crimes de natureza homofóbica no mundo (SECRETARIA, 2007, p. 26).
} 
hemerográficas, 19 pela primeira vez o Estado manifesta-se oficialmente através da compilação de dados ${ }^{20}$ obtidos em órgãos governamentais da União, ${ }^{21}$ consistentes em homicídios, agressões verbais e físicas e crimes de ódio tipificados no Código Penal. As estatísticas analisadas foram baseadas em denúncias relatadas ao Poder Público sobre violações de direitos humanos da população LGBT em todo o território nacional durante o ano de 2011. Tais estatísticas são definidas como cruciais para o embasamento, a monitoração e a avaliação de políticas públicas, para permitir o controle por parte da sociedade civil organizada e a vigilância por parte da comunidade internacional.

Reconhecendo dissidências acerca do conceito de homofobia (como já mencionados nos parágrafos supra), o Relatório indica como postulado a homofobia enquanto "preconceito e discriminação (e demais violências daí decorrentes) contra pessoas em função de sua orientação sexual e/ou identidade de gênero presumidas, (...) incluídas a lesbofobia, a homofobia, a transfobia e a bifobia (ou seja, a LGBTfobia em geral)" (BRASIL, 2011b, p. 9), e ressalta que o conceito inclui "desde a negação de oportunidades de emprego e educação, discriminações relacionadas ao gozo de ampla gama de direitos humanos até estupros, agressões sexuais, tortura e homicídios" (Ibid., p. 6), perpetradas nos ambientes familiar, escolar, laboral, judiciário, na polícia, nas Forças Armadas e em diversas outras esferas do Poder Público.

Entre janeiro e dezembro de 2011, o Relatório (BRASIL, 2011b) acusa, com base em 1.681 denúncias reportadas, 6.809 violações de direitos humanos contra LGBT, envolvendo 1.713 vítimas e 2.275 suspeitas. Isso significa que no Brasil, no ano de 2011, foram reportadas 18,65 violações de direitos por motivos homofóbicos contra 4,49 vítimas a cada dia. A princípio, os números chamam a atenção para a média de 3,97 violações sofridas por

\footnotetext{
${ }^{19}$ Dados hemerográficos são estatísticas não oficiais baseadas em notícias veiculadas através das mídias impressas, da internet, da televisão e do rádio. O Grupo Gay da Bahia foi o pioneiro nessa pesquisa, realizada desde a década de 80 do século passado. Segundo esses dados, em 2011 foram noticiadas nos principais jornais brasileiros 478 violações contra as populações LGBT, envolvendo 478 vítimas e 652 suspeitas, incluindo 278 homicídios. O acompanhamento desses dados relativos a 2011 pode ser feito em BRASIL, 2011b, pp. 52-72.

${ }^{20}$ Sobre a metodologia empregada no Relatório, conferir BRASIL (2011b, pp. 11-16). Os números foram coletados especialmente a partir do banco de dados do Disque Direitos Humanos (Disque 100) da Secretaria de Direitos Humanos da Presidência da República (SDH/PR), serviço de denúncia vinculado à Ouvidoria da Secretaria que sistematiza, desde dezembro de 2010, violações cometidas contra a população LGBT. Subsidiariamente, obtiveram-se dados da Central de Atendimento à Mulher (Ligue 180), do Disque Saúde e Ouvidoria do SUS e de e-mails e correspondências diretamente enviadas ao Conselho Nacional de Combate à Discriminação LGBT e à Coordenação-Geral de Promoção dos Direitos de LGBT, vinculada à CoordenaçãoGeral de Promoção e Defesa de Direitos Humanos da SDH/PR.

${ }^{21} \mathrm{O}$ Conselho Nacional de Combate à Discriminação (CNCD/LGBT) solicitou às Secretarias de Segurança Pública estaduais informações sobre violência homofóbica referentes a todas as unidades da federação, registradas nos órgãos de segurança pública. No entanto, apenas 7 estados-membros enviaram seus dados, os quais foram analisados em separado no anexo 1 da publicação (BRASIL, 2011b, pp. 123-127).
} 
cada vítima, o que pode significar o cometimento de abusos reiterados contra um mesmo sujeito, e para o número maior de suspeitas em relação ao de vítimas (diferença de 32,8\%), o que sugere violências cometidas coletivamente por grupos de agressoras em alguns casos. Mais além, devemos ter em mente a probabilidade de subnotificações, já que os dados restringem-se às situações conduzidas ao conhecimento das autoridades públicas; e podemos supor que, por diversos motivos, a violência homofóbica teve lugar em numerosas situações não levadas a conhecimento. Reproduziremos aqui os dados que reputamos mais relevantes a respeito do perfil das vítimas (tabela 1), do perfil das agressoras suspeitas (tabela 2), dos locais de agressão e dos tipos de violação.

Tabela 1: Perfil das vítimas

\begin{tabular}{|c|c|c|c|c|}
\hline Sexo biológico & Masculino: $67,8 \%$ & Feminino: $26,4 \%$ & & $\begin{array}{l}\text { Não informado: } \\
6,1 \%\end{array}$ \\
\hline $\begin{array}{l}\text { Identidade de } \\
\text { gênero }\end{array}$ & Masculina: 5,34\% & Feminina: $34,5 \%$ & $\begin{array}{lr}\text { Travestis: } & 10,6 \% \text {; } \\
\text { mulheres } & \text { trans: } \\
10,6 \% ; & \text { homens } \\
\text { trans: } 0,6 \% & \end{array}$ & $\begin{array}{ll}\text { Não informada: } \\
18,6 \%\end{array}$ \\
\hline Orientação sexual & $\begin{array}{l}\text { Homossexual: } \\
85,5 \%\end{array}$ & Bissexual: $9,5 \%$ & $\begin{array}{l}\text { Heterossexual: } \\
1,6 \%\end{array}$ & $\begin{array}{l}\text { Não informada: } \\
3,4 \%\end{array}$ \\
\hline Raça/ cor & $\begin{array}{l}\text { Negra } \quad \text { preta } \quad \text { e } \\
\text { parda): } 51,1 \%\end{array}$ & Branca: $44,5 \%$ & $\begin{array}{l}\text { Amarela e indígena: } \\
3,40 \%\end{array}$ & \\
\hline Faixa etária & $\begin{array}{l}\text { Jovens entre } 19 \text { e } \\
29 \text { anos: } 31,1 \%\end{array}$ & $\begin{array}{l}\text { Jovens entre } 15 \mathrm{e} \\
18 \text { anos: } 16,0 \%\end{array}$ & $\begin{array}{ll}\text { Outras idades: } \\
21,2 \%\end{array}$ & $\begin{array}{l}\text { Não informada: } \\
31,7 \%\end{array}$ \\
\hline Escolaridade & $\begin{array}{l}\text { Ensino fundamental } \\
\text { e médio (completo } \\
\text { e incompleto): } \\
56,8 \%\end{array}$ & $\begin{array}{l}\text { Ensino superior } \mathrm{e} \\
\text { pós-graduação } \\
\text { (completo } \\
\text { incompleto): } 13,9 \%\end{array}$ & Analfabetas: $1,5 \%$ & $\begin{array}{l}\text { Não informada: } \\
28,0 \%\end{array}$ \\
\hline
\end{tabular}

Algumas interpretações podem ser extraídas dos dados: (A) A predominância de vítimas do sexo masculino é uma constante nos estudos sobre violência no Brasil. Isto pode significar tanto que os homens estão mais expostos à violência em geral, quanto que há uma maior intolerância e, consequentemente, maior agressividade sobre a homossexualidade masculina. (B) Podemos notar uma baixa representatividade de travestis e transexuais entre as vítimas, talvez devido ao desconhecimento dos canais de denúncia e o receio de retaliações e de transfobia institucional por parte dessas populações. (C) Quanto à categorização de orientação sexual, podemos encontrar incluídas na categoria "homossexual" as travestis e as/ 
os transexuais, em razão do fato de que tais pessoas são vulgarmente consideradas homossexuais num sentido amplo. (D) Os dados corroboram que a população negra, inclusive LGBT, é a maior vítima de violências no Brasil. (E) O predomínio das vítimas de até 29 anos $(50,3 \%)$ pode significar que pessoas nessa faixa etária tiveram mais acesso aos canais de denúncia e às lutas por visibilização e direitos LGBT.

Tabela 2: Perfil das agressoras suspeitas

\begin{tabular}{|c|c|c|c|c|}
\hline $\begin{array}{lr}\text { Relação } & \text { entre } \\
\text { vítimas } & \text { e } \\
\text { suspeitas: } & \end{array}$ & Conhecidas: $61,9 \%$ & $\begin{array}{l}\text { Desconhecidas: } \\
29,4 \%\end{array}$ & & $\begin{array}{l}\text { Não informada: } \\
8,7 \%\end{array}$ \\
\hline $\begin{array}{l}\text { Relação entre } \\
\text { vítimas e suspeitas } \\
\text { que já se } \\
\text { conheciam }\end{array}$ & Familiares: $38,2 \%$ & Vizinhas: $35,8 \%$ & Outras: $25,8 \%$ & \\
\hline Sexo biológico & Masculino: $52,5 \%$ & Feminino: $34,5 \%$ & & $\begin{array}{ll}\text { Não } & \text { informado: } \\
12,9 \% & \end{array}$ \\
\hline $\begin{array}{l}\text { Identidade de } \\
\text { gênero }\end{array}$ & Masculina: $30,6 \%$ & Feminina: $22,1 \%$ & Travesti: $0,4 \%$ & $\begin{array}{l}\text { Não informada: } \\
46,9 \%\end{array}$ \\
\hline Orientação sexual & $\begin{array}{l}\text { Heterossexual: } \\
43,9 \%\end{array}$ & Homossexual: $9,5 \%$ & Bissexual: $2,2 \%$ & $\begin{array}{l}\text { Não informada: } \\
44,4 \%\end{array}$ \\
\hline Raça/ cor & $\begin{array}{l}\text { Negra } \quad \text { preta } \mathrm{e} \\
\text { parda): } 32,3 \%\end{array}$ & Branca: $31,2 \%$ & $\begin{array}{l}\text { Amarela e indígena: } \\
1,6 \%\end{array}$ & $\begin{array}{l}\text { Não informada: } \\
34,9 \%\end{array}$ \\
\hline Faixa etária & $\begin{array}{l}\text { De } 15 \text { a } 29 \text { anos: } \\
18,1 \%\end{array}$ & $\begin{array}{l}\text { De } 30 \text { a } 39 \text { anos: } \\
10,1 \%\end{array}$ & Outras: $16,4 \%$ & $\begin{array}{l}\text { Não informada: } \\
55,2 \%\end{array}$ \\
\hline Escolaridade & $\begin{array}{l}\text { Ensino fundamental } \\
\text { e médio (completo } \\
\text { e incompleto): } \\
18,2 \%\end{array}$ & $\begin{array}{l}\text { Ensino superior e } \\
\text { pós-graduação: } \\
\text { (completo } \\
\text { incompleto): } 6,3 \%\end{array}$ & Analfabetas: $2,5 \%$ & $\begin{array}{l}\text { Não informada: } \\
73,1 \%\end{array}$ \\
\hline
\end{tabular}

Algumas informações podem ser extraídas dos dados: (A) É mais comum a violência praticada por conhecidas, sobretudo familiares e vizinhas da vítima. (B) Novamente, é reafirmada a maior tendência entre agressores do sexo masculino. $(C)$ As maiores agressoras são pessoas heterossexuais, o que desmistifica a preconcepção muito alargada no senso comum de que são majoritariamente homossexuais que perpetuam a violência entre si. (D) No caso das agressoras, a porcentagem de negras e brancas é muito próxima. (E) Não foi possível saber o nível de escolaridade da esmagadora maioria das agressoras, pois tais informações são 
de difícil obtenção, uma vez que a vítima não conhece boa parte das suspeitas ou não sabe afirmar a escolaridade mesmo das conhecidas.

Quanto aos locais de agressão (Ibid., pp. 38-39), foi possível concluir que violências homofóbicas ocorrem tanto em espaços privados, como no lar familiar, quanto em espaços públicos, tais como ruas, estradas, escolas, instituições públicas, hospitais e restaurantes. O maior local de ocorrência são as casas (42\%), sendo que 21,1\% tiveram lugar na casa da vítima e 7,5\% na das suspeitas. O segundo lugar de maior ocorrência são as ruas (30,8\%). Além desses polos principais, 5,5\% das violações reportadas ocorrem em instituições governamentais: escolas e universidades $(3,9 \%)$, instituições de saúde $(0,9 \%)$ e instituições de segurança pública $(0,7 \%)$. A categoria "outros locais" inclui instituições religiosas $(0,2 \%)$, bares e boates, praias, rios, lagoas, terrenos baldios e construções abandonas, banheiros públicos, postos, albergues, motéis, pousadas, entre outros.

Quanto aos tipos de violação (Ibid., pp. 39-51), as violências psicológicas foram as mais reportadas (42,5\%), seguidas de discriminações $(22,3 \%)$ e violências físicas $(15,9 \%)$. Também houve coeficiente notável de negligências ${ }^{22}$ (466 violações) e violências sexuais ${ }^{23}$ (377 violações). Dos tipos mais frequentes de violência psicológica, destacam-se humilhações (32,3\%), hostilizações $(25,9 \%)$ e ameaças $(20,6 \%)$. Calúnia, injúria e difamação, crimes definidos no Código Penal, contaram com 9,7\% da violência psicológica. Esta foi mais presente nas casas $(36,9 \%)$. As discriminações - definidas como comportamentos, atitudes e tratamento diferencial de pessoas - por orientação sexual corresponderam a 78,6\% do total de discriminações ouvidas, enquanto a discriminação por identidade de gênero (categoria que inclui as transfobias) correspondeu a $14,1 \%$. As ruas foram os principais ambientes de discriminação (33,6\%). Violências físicas foram classificadas em lesões corporais $(55,7 \%)$, maus tratos $(31,8 \%)$ e tentativas de homicídio $(3,7 \%)$. Evidentemente, houve considerável subnotificação de homicídios em serviços de teledenúncias: uma vez a vítima morta, raramente conhecidas suas preocupam-se em comunicar a violência para esse tipo de serviço. Dentre os casos de violência física, a maior parte $(45,6 \%)$ também ocorreu na casa da vítima. Dentre as violências institucionais (2,4\% das violações), destaca-se a homofobia institucional $(35,8 \%)$, tal como a recusa de atendimento $(13,3 \%)$ e a violência policial $(12 \%)$.

\footnotetext{
${ }^{22}$ Negligência implica abandono, descuido, desamparo, descompromisso e desresponsabilização do cuidado e do afeto (Ibid., p. 45); corresponde a 6,8\% do total de violações; negligência em amparo e responsabilização (45,9\% das negligências) inclui os pais ou responsáveis que expulsam as crianças e adolescentes LGBT de casa. Negligências ocorrem principalmente no âmbito doméstico (74,5\%).

${ }^{23}$ Importante ressaltar que $63,5 \%$ das violências sexuais ocorreram no âmbito privado, dentro das próprias casas das vítimas.
} 
O Relatório sobre violência homofóbica do Governo Federal é conclusivo em tom peremptório:

Podemos concluir que a homofobia no Brasil é estrutural, operando de forma a desumanizar as expressões de sexualidade divergentes da heterossexual, atingindo a população de lésbicas, gays, bissexuais, travestis, transexuais em todos os níveis e podendo ser encontrada nos mais diversos espaços, desde os institucionais até o nível familiar. Os dados denunciam que a sociedade brasileira ainda é extremamente sexista, machista e misógina (BRASIL, 2011b, p. 116).

Uma vez reconhecidas a homofobia, o heterossexismo, o machismo e a misoginia como problemas estruturais, a partir de dados quantitativos e qualitativos sólidos, o estudo termina com várias recomendações sobre formas de erradicar ou ao menos minimizar essas graves violações de direitos humanos. A recomendação 11 expressa: "Que prisões, escolas, hospitais, quartéis e outras instituições similares possuam um código de ética ou incluam em seus códigos de ética questões relacionadas ao respeito dos direitos das minorias" (Ibid., p. 118, grifamos). Tal diretriz conduz à nossa exploração sobre a homofobia nas escolas e o papel do sistema escolar, enquanto instituição social fundamental, na erradicação ou minoração dessa forma insidiosa de preconceito.

\section{2 Homofobia nas escolas}

Vimos na seção anterior como a heteronormatividade é a base da homofobia, da transfobia e do heterossexismo em geral. Chegando neste ponto, cabe-nos perguntar pelos meios através dos quais essa norma, inicialmente difusa nas práticas e instituições sociais, se introjeta no cotidiano das vidas humanas sob a forma de sentimentos, atitudes, comportamentos, saberes, representações etc. De fato, existe uma verdadeira pedagogia da sexualidade responsável por moldar a identidade de meninos e meninas, ainda na infância, condicionando seus hábitos conforme o modelo da matriz heterossexual e legitimando alguns comportamentos às expensas da repressão e da marginalização de outros. Às meninas e aos meninos é deixado um limitado campo de ação social legítima, restringido pelas noções mutuamente referentes de heterossexualidade e homossexualidade. Este campo de ação é garantido cotidianamente mediante dispositivos pedagógicos de gênero ${ }^{24}$ e dispositivos de

\footnotetext{
24 Dispositivos pedagógicos de gênero são procedimentos sociais pelos quais um indivíduo aprende ou transforma os componentes de gênero da sua subjetividade. São modos de pensar, sentir e agir, considerados apropriados de forma diferente e diametralmente oposta para alunos e alunas. Apesar de tácitos e sutis, tais
} 
sexualidade $^{25}$ disponíveis e operantes na sociedade disciplinar (ver FOUCAULT, 1988; LOURO, 2000, p. 20; LOURO, 1997, p. 41; WEEKS, 2000, p. 44). A sexualidade é um dispositivo na medida em que pode ser entendida como um conjunto de redes reguladoras de poder, como são as instituições, leis, religiões, proposições morais e filosóficas etc.

A matriz da heterossexualidade compulsória é um ente ficcional, um ideal regulatório (BUTLER, 2000, p. 152) pelo qual se comparam as práticas sexuais, afetivas e performativas concretas dos indivíduos tendo em vista uma aproximação tanto quanto possível a seus ditames: quanto mais uma criança se aproxima dessa padronização, mais tranquila será sua aceitação em termos de identidade sexual, mais pacífico será seu relacionamento com pais, mães, familiares, colegas e educadoras. Assim, a todo tempo nos estamos comparando, escrutinando e reelaborando para que mantenhamos o contato com os projetos de sexualidade. Até porque muitos dos conflitos sexuais se dão devido ao afastamento dessa diretriz, a partir da qual certas pessoas são julgadas como corretas ou desviantes, mesmo que seja razoável admitir que poucos homens e poucas mulheres detêm o conjunto completo dos atributos prescritos para a masculinidade e a feminilidade hegemônicas (BELLO, FELIPE, 2009, p. 144). A vontade de normalidade está por trás da própria elaboração das sexualidades desde a primeira infância: "quando queremos/ precisamos articular as nossas identidades, é premente que comecemos a indicar os diferentes de nós (aqueles sujeitos em oposição aos quais nos identificamos), utilizando-os como referência, para localizar o que estamos tentando ser" (Ibid., p. 144). Essa demarcação fundante dá-se a partir do desprezo ${ }^{26}$ pelas formas apontadas como diferentes, diversas, minoritárias, pelo "Outro". A percepção do "Outro abjeto" gera, nas palavras de Judith BUTLER (2000, p. 156), um repúdio sem o qual o sujeito não pode emergir: "o sujeito é constituído através da força da exclusão e da abjeção, uma força que produz um exterior constitutivo relativamente ao sujeito".

\footnotetext{
dispositivos estão firmemente presentes "no currículo, nas imagens, nas expectativas, nos costumes e nas trocas que se estabelecem entre os sujeitos escolares" (BRASIL, 2011a, p.22).

${ }^{25}$ Foucault aponta quatro estratégias centradas na relação entre poder e sexo que justificaram uma variedade de práticas sociais e técnicas de poder desde o século XVIII. Elas giram em torno da preocupação com a sexualidade das mulheres, com a sexualidade das crianças, com o comportamento procriativo e com a patologização das perversões sexuais. Essas estratégias deram à luz quatro figuras inventadas no interior dos discursos reguladores e submetidas a intenso controle: a mulher histérica, a criança masturbadora, o casal que utiliza formas artificiais para controlar a procriação e o "pervertido" (especialmente o homossexual) (WEEKS, 2000, p. 50).

${ }^{26}$ BELLO e FELIPE (2009, p. 146) afirmam existir um dispositivo mais rígido para disciplinar a sexualidade dos homens/ meninos, enquanto as mulheres/ meninas são mais comumente submetidas aos dispositivos sexistas de gênero. Por isso, aqueles seriam mais suscetíveis às ações homofóbicas, que guardam em si um grande componente de misoginia, isto é, do desprezo e da inferiorização de tudo aquilo que possa parecer feminino.
} 
O relacionamento das crianças com pessoas adultas, escola e outras crianças é permeado pelo enraizamento dos saberes relativos ao modo "correto" de se posicionar em torno da matriz heteronormativa, e isso se dá em diversas instâncias sociais, principalmente na família e na escola (se desconsiderarmos, a princípio, a influência da mídia e da publicidade, ${ }^{27}$ através de filmes, músicas, programas de televisão, propagandas, revistas e gibis etc.). No interior das famílias, a priori protegidas das interferências públicas graças ao manto da privacidade, a norma é tanto mais ou menos cobrada na medida da imposição exercida pelos chefes de família, de forma variável, embora possamos afirmar que ela seguramente existe na maioria dos lares. Quanto à escola - objeto de nosso interesse neste momento -, é possível observar que uma de suas funções é justamente a vigilância disciplinar.

No que tange ao disciplinamento da sexualidade, a escola institui uma espécie de homofobia compartilhada com a família e demais espaços sociais, tratando a homossexualidade como se fosse uma perversão contagiosa. Identidades sexuais de garotas e garotos são moldadas por meio de pressão psicológica, violência, persuasão e constrangimento, ${ }^{28}$ até que se consiga forjar seus respectivos desejos permitidos e proibidos. Paradoxalmente, ao tratar da homossexualidade, costuma-se invisibilizá-la através de um silêncio persistente, que reitera a naturalização da heteronorma. Os currículos ${ }^{29}$ e livros didáticos nunca ou quase nunca mencionam sexualidades oprimidas ou casais homoafetivos como possibilidade concreta de união afetiva e conjugal, como se tais pessoas e arranjos não existissem. O silenciamento por si só é uma das formas mais pungentes de homofobia.

\footnotetext{
27 "Os anúncios publicitários geralmente mostram a heterossexualidade como única expressão de afeto sexual. Os comentários feitos nos meios de comunicação a respeito da diversidade sexual, muitas vezes, são expressões da homofobia. Durante muito tempo programas humorísticos de TV apresentaram personagens homossexuais de forma invariavelmente caricatural. Se fosse feito um compêndio das piadas que circulam no dia a dia, comprovaríamos que uma grande porcentagem delas envolve gozações em relação ao segmento LGBT. Sem esquecer que 'viado' e 'sapatão' são os termos preferidos quando se quer ofender alguém gravemente" (BRASIL, 2011a, p. 36). Pode-se notar que nesses canais não existe uma única palavra positiva para designar socialmente as LGBT.

${ }^{28}$ Atualmente, está em foco a discussão sobre o bullying, que consiste em "atitudes sistemáticas dos estudantes em geral (mas infelizmente não apenas elas e eles) para desqualificar, destratar, ridicularizar e até de agredir fisicamente alguém em função da aparência física, do peso, do tom da pele, da cor dos olhos ou dos cabelos, da religião, dos hábitos culturais, da classe social etc.”. (BRASIL, 2011a, p. 36). Certamente o bullying homofóbico é uma das modalidades mais presentes (arriscaríamos dizer que $a$ mais presente, em muitos casos) de discriminação sistemática no ambiente escolar. Seus efeitos mais perversos incluem a deterioração da autoestima daquela que o sofre, à qual é impingida a culpa por ser o que é, uma verdadeira internalização da culpa no seu processo de individuação subjetiva, que pode chegar ao desejo de negação do próprio ego.

${ }^{29} \mathrm{Se}$, por um lado, os currículos oficiais não incluem conteúdos que abordam diretamente as temáticas de gênero e orientação sexual, é lícito reconhecer que essas temáticas estão subliminarmente presentes no currículo oculto das escolas. O currículo oculto é constituído por aspectos do ambiente escolar, tais como atitudes e valores transmitidos pelas rotinas do cotidiano escolar, que contribuem de forma implícita para aprendizagens sociais relevantes. É através do currículo oculto que se aprende a ser homem ou mulher, heterossexual ou homossexual. Porém, os valores, as crenças, os interesses, as atitudes e as orientações desse currículo não são discutidas, fato que tem se tornado central em discussões da Pedagogia.
} 
Contudo, dificilmente professoras e professores ignorariam a existência da homossexualidade dentro e fora da escola. Falar ou não em homossexualidade constitui uma opção política que influencia os modos de lidar com o respeito e com a aceitação entre as pessoas em contextos de diversidade. Não problematizar as questões de diferença sexual é manter o status quo e se resignar diante da discriminação e do preconceito. "Entender os processos de produção de representações de gênero e sexualidade como locais de disputas políticas e que envolvem relações desiguais de poder torna-se fundamental para uma prática pedagógica que reconhece seus limites e reconfigura suas possibilidades" (BELLO, FELIPE, 2009, p. 152).

$\mathrm{O}$ aspecto de politização dos processos de aprendizagem e das linguagens da pedagogia escolar é inegável: a escola é palco de disputa sobre afirmação, rejeição ou resistência de identidades. Os sujeitos não participam passivamente como meros espectadores dos processos de produção: meninas e meninos são entes ativos na construção de suas próprias identidades, com base em vivências, experiências e conhecimentos adquiridos não só na escola e na família, como também na rua, na televisão, na internet e nas suas relações com pessoas adultas e outras crianças. Enquanto algumas sucumbem ao marketing identitário hegemônico através da assimilação e da acomodação, outras desafiam permanentemente tais injunções, resistindo às imposições e implicações, subvertendo regras e expectativas sociais, escapando do controle e da regulação, negando os padrões e, assim, explicitando sua pluralidade e particularidade (FURLANI, 2009, p. 321). O desafio de lidar com essas estudantes é a primeira questão que deve orientar uma adequada pedagogia da sexualidade.

Relações de poder entre os sexos são visíveis desde a infância. Mais precisamente, a atribuição de um gênero a fim de definir identidades e consequentemente posições-de-sujeito, lugares sociais e papeis funcionais a serem ocupados pelos indivíduos humanos é confabulada desde antes do nascimento. O fato de se nascer "menino" ou "menina" não é nada trivial.

Nesse sentido, a matriz das relações de gênero é anterior à emergência do "humano". Consideremos a interpelação médica que, apesar das recentes ecografias, transforma a criança, de um ser "neutro" em um "ele" ou em um "ela": nessa nomeação, a garota torna-se uma garota, ela é trazida para o domínio da linguagem e do parentesco através da interpelação do gênero. Mas esse tornar-se garota não termina ali; pelo contrário, essa interpelação fundante é reiterada por várias autoridades, e ao longo de vários intervalos de tempo, para reforçar ou contestar esse efeito naturalizado. A nomeação é, ao mesmo tempo, o estabelecimento de uma fronteira e também a inculcação repetida de uma norma (BUTLER, 2000, p. 161). 
A naturalização dos padrões de masculinidade e feminilidade ${ }^{30}$ é imposta mediante processos escolares não raro violentos e acentuadamente excludentes. Esses processos são empregados por pais, mães e educadoras em colaboração: é comum que a família requisite certos controles e proibições a serem aplicados pelas professoras, ao passo que a escola, vigilante incansável da sexualidade infantil, costuma chamar mães e pais para conversar toda vez que demonstra preocupação com algum "desvio" observado no aluno ou na aluna. Submetidas a esses artifícios, muitas crianças passam a expressar profunda rejeição ${ }^{31}$ aos comportamentos desviantes daqueles estabelecidos pela cultura hegemônica da masculinidade e da feminilidade. Crianças pequenas já desenvolvem comportamentos que poderíamos chamar de homofóbicos, exercendo um constante autocontrole sobre seus próprios corpos e desejos, bem como um controle dos corpos das colegas. Desta forma, a homofobia torna-se um problema central nas escolas e passa a requerer políticas públicas para sua eliminação.

A mais incisiva das políticas públicas de combate à homofobia nas escolas, o Projeto Escola Sem Homofobia (PESH), de 2011, previu como componente de pesquisa a elaboração de um estudo qualitativo ${ }^{32}$ sobre violência homofóbica em escolas de 11 capitais ${ }^{33}$ brasileiras,

\footnotetext{
${ }^{30}$ Robert Connell (apud LOURO, 1997, p. 48) pensa na masculinidade como um projeto aberto, continuamente se transformando e se afetando por inúmeras instituições e práticas. As políticas de masculinidades (e feminilidades) trazem narrativas convencionais sobre a maneira como a autocompreensão sexual é construída, sobre as condutas e os sentimentos adequados para cada sexo. A narrativa convencional adota uma das possíveis formas de manifestação da masculinidade, não mais legítima, mas apenas mais visível socialmente, para definir a masculinidade em geral. No entanto, essa masculinidade se produz juntamente e em relação com outras masculinidades.

${ }^{31}$ Em levantamento feito em 2004, aproximadamente 1/4 dos alunos indicaram que não gostariam de ter um colega homossexual, resposta mais repetida por alunos do sexo masculino. Interessante notar que a taxa de rejeição é ainda maior quando perguntados os pais: a proporção de pais que não gostariam que seus filhos estudassem junto de colegas homossexuais varia de 47,5\% em Fortaleza a $13 \%$ em Porto Alegre (ABRAMOVAY et al, 2004, p. 280). A comparação das reações de pais, meninos e meninas pode nos levar a formular duas rápidas conjeturas: a) crianças do sexo masculino têm mais rejeição à homossexualidade, o que corrobora a ideia de que a vigilância sobre a heterossexualidade masculina, componente de uma sociedade androcêntrica, é mais efetiva; e $b$ ) as gerações anteriores têm mais dificuldade de lidar com o tema da homossexualidade, o que nos permite indagar se as gerações futuras serão ainda menos preconceituosas que as atuais, segundo uma lógica progressiva.

32 Os resultados de todas as capitais foram agrupados nas seguintes categorias de análise: ambiente escolar, políticas de educação sexual, diversidade sexual na escola, postura, atitude e prática da escola frente a estudantes LGBT, percepção da família frente a filhos LGBT, homofobia na escola, causas e consequências da homofobia e outros achados relevantes. Houve o cuidado de representar as 5 regiões do país através da seleção das cidades participantes. Em cada município foram selecionadas quatros escolas com ensino de $6^{\circ}$ a $9^{\circ}$ ano, sendo duas estaduais e duas municipais, escolhidas de maneira aleatória. No total foram entrevistadas 1.406 pessoas, entre autoridades municipais de educação (10), autoridades estaduais de educação (11), gestores escolares (87), professores e professoras (403), estudantes (385) e funcionários (510). A metodologia de pesquisa empregada está descrita em REPROLATINA (2011, pp. 21-29).

${ }^{33}$ São elas: Belo Horizonte-MG, Cuiabá-MT, Curitiba-PR, Goiânia-GO, Manaus-AM, Natal-RN, Porto AlegreRS, Porto Velho-RO, Recife-RE, Rio de Janeiro-RJ e São Paulo-SP.
} 
a ser realizado pela ONG Reprolatina - Soluções Inovadores em Saúde Sexual e Reprodutiva. ${ }^{34}$ A pesquisa ${ }^{35}$ se propôs a:

conhecer as percepções, conhecimentos e atitudes da comunidade escolar frente às diversidades e orientações sexuais e de gênero, conceito e percepção da homofobia e do programa Brasil sem Homofobia no processo educativo, focalizando Secretarias Estaduais e Municipais de Educação e escolas do Ensino Fundamental ( $6^{\circ}$ a $9^{\circ}$ ano) da rede pública (REPROLATINA, 2001, p. 8). (...) Seu objetivo foi tentar compreender como são abordadas as diversidades sexuais nas escolas, conhecer melhor se existe homofobia nas escolas, quais são as causas que originam e permitem que a homofobia continue vigente, conhecer se as políticas públicas relacionadas estão ou não implementadas nas escolas e quais as causas que fazem com que as políticas públicas não tenham o efeito esperado de reduzir a homofobia (Ibid., 2011, p. 19).

Não seria possível aprofundarmo-nos em todas as incontáveis conclusões da pesquisa, por questões de exiguidade de espaço e adequação temática. Concentremo-nos na principal conclusão do relatório final (REPROLATINA, 2011): de fato, a homofobia existe nas escolas e é reconhecida pela grande maioria das participantes como um problema relevante que merece atenção de toda a sociedade para ser enfaticamente combatido (p. 53). Os relatos variam entre tipos de agressão: desde violência verbal a violência física, praticada por estudantes, educadoras e funcionárias (p. 49). As consequências da homofobia são muito prejudiciais para adolescentes LGBT: os relatos colheram situações de tristeza, isolamento, baixa autoestima, violência e até suicídio. ${ }^{36} \mathrm{~A}$ escola é especialmente hostil a travestis e transexuais, fator responsável pelo alto nível de evasão escolar ${ }^{37}$ dessas pessoas (p. 65).

\footnotetext{
${ }^{34} \mathrm{O}$ estudo contou ainda com a parceria das ONGs Pathfinder do Brasil, ABGLT, GALE e ECOS, além do apoio técnico e financeiro da Secretaria de Educação Continuada, Alfabetização e Diversidade (SECAD), do Fundo Nacional de Desenvolvimento da Educação (FNDE) e do Ministério da Educação (MEC). Também contou com apoio das Secretarias de Estado de Educação dos estados onde a pesquisa foi realizada e suas respectivas Prefeituras Municipais e Secretarias Municipais de Educação. As coordenadoras da pesquisa foram Margarita Diaz, Francisco Cabral e Magda Loureiro Motta Chinaglia. Também envolveu pesquisadoras da Reprolatina atuantes em cada cidade e assistentes locais de pesquisa.

35 Pesquisa semelhante foi realizada em 2004 a pedido da UNESCO, coordenada por Mary Garcia Castro, Miriam Abramovay e Lorena Bernadete da Silva (ABRAMOVAY et al, 2004), com o apoio do Ministério da Educação, do Ministério da Saúde, da Secretaria Especial de Políticas para as Mulheres e do Instituto Ayrton Senna. Participaram da pesquisa 241 escolas públicas e privadas do Distrito Federal e de 13 capitais brasileiras (Belém-PA, Cuiabá-MT, Florianópolis-SC, Fortaleza-CE, Goiânia-GO, Maceió-AL, Manaus-AM, Porto AlegreRS, Recife-PE, Rio de Janeiro-RJ, Salvador-BA, São Paulo-SP e Vitória-ES). Agregaremos algumas das conclusões obtidas neste estudo às conclusões do relatório final da Reprolatina, quando julgarmos enriquecedor para explanar os dados.

36 As restrições da livre expressão afetivo-sexual têm forte impacto na trajetória educacional e pessoal das LGBT. Estudos realizados na América do Norte e na Europa acusam um risco de suicídio extremamente maior entre adolescentes homossexuais (SECRETARIA, 2007, p. 27).

37 Nenhuma escola pública pode expulsar uma aluna ou um aluno com base em sua orientação sexual ou identidade de gênero. Não obstante, pressões sociais latentes exercidas sobre esse segmento pode levar essas pessoas a abandonar a escola.
} 
Não obstante, contraditoriamente a população LGBT é invisibilizada nas escolas na medida em que a homofobia é naturalizada, minimizada e, consequentemente, retirada da pauta de discussões, do currículo e dos conteúdos das aulas ministradas. A maioria das professoras qualificou as piadas e agressões verbais ${ }^{38}$ contra sexualidades oprimidas como brincadeiras inofensivas, e não indícios de homofobia, sendo que esta tem seu reconhecimento maior entre estudantes do que por parte das educadoras e das autoridades de ensino. Estudantes referem-se à escola como omissa frente às estudantes LGBT, aduzindo que as professoras evitam discutir temas como diversidade sexual, discriminação e homofobia; muitas professoras admitiram a existência da homofobia, mas disseram ou não estar preparadas $^{39}$ para lidar com isso ou não ter tempo suficiente para tratá-la diante dos conturbados afazeres escolares (p. 52). Soma-se a isso a diferença de valores entre alunado e professorado, causada pela distância geracional entre uns e outros, referente ao contexto moral de onde retiram seus respectivos valores (SEFFNER, 2009, p. 131). Foi atestado grande desconhecimento sobre os conceitos básicos de sexualidade. Embora o discurso em geral seja de tolerância com relação à diversidade, a maioria das pessoas não aceita a homossexualidade por considerá-la doença, ${ }^{40}$ perversão, desvio, pecado ou anormalidade (REPROLATINA, 2011, p. 64). Evidentemente, houve depoimentos de estudantes, educadoras e autoridades que não aprovavam a homofobia (p. 51).

Parte das entrevistadas e dos grupos focais de discussão ressaltaram a necessidade de implementar programas de formação de educadoras e produzir materiais para uma mais competente abordagem da homofobia na escola ${ }^{41}$ (p. 65). Quando da divulgação dos

\footnotetext{
${ }^{38}$ Nas palavras de ABRAMOVAY et al. (2004, p. 286): “A recorrência à linguagem pejorativa é comum nas violências contra homossexuais. É importante destacar a linguagem porque por ela se apresenta visões de mundo, representações e também a nomeação do outro por formas negativas ou contrárias à sua vontade, com o intuito de humilhar, discriminar, ofender, ignorar, isolar, tiranizar e ameaçar. No caso da escola, em que o verbo é matéria-prima, o cuidado com a linguagem, com os discursos de alunos e de professores ganha mais relevância, indicando problemas no objetivo do projeto escolar de formar mentalidades por parâmetros de igualdade".

39 "Alguns professores comentam que, apesar de abordarem a questão da homossexualidade pelo lado do respeito humano, é bastante difícil lidar com o assunto, pois os alunos sempre levam para a brincadeira. Já outros assumem uma postura de distanciamento e assim de cumplicidade passiva com a violência contra jovens tidos como homossexuais - cada um é, pode ser como quiser ou como um tema que não é de sua alçada. Desta forma, omite-se o debate sobre assuntos que são engendrados por preconceitos e discriminações, quando muito pregando uma abstrata tolerância, em que cada um poderia ser o que quisesse, quando, na prática, não é isso que ocorre" (ABRAMOVAY et al., 2004, p. 288).

${ }^{40}$ ABRAMOVAY et al. (2004, pp. 293-294) anota que é promissor o fato de que mais de $80 \%$ dos alunos em cada capital pesquisada não consideram “o 'homossexualismo' uma doença”. O percentual de meninos que concordam com essa assertiva é sempre superior ao de meninas. $\mathrm{O}$ percentual de professoras que endossam essa assertiva variou entre 22\% em Fortaleza (máximo) e 7\% em Florianópolis (mínimo).

${ }^{41}$ Alguns depoimentos obtidos por ABRAMOVAY et al. (2004) foram otimistas quanto à capacidade da escola de desconstruir discriminações, incluir pessoas e fomentar o respeito à diversidade. "Vários professores afirmam que o preconceito deve ser combatido pela escola. As diferenças devem ser respeitadas e os alunos devem-se
} 
resultados, boa parte das entrevistadas se mostrou surpresa e preocupada com a situação vivenciada pelas estudantes LGBT, declarando que não tinham se dado conta da dimensão do problema e do sofrimento por elas suportado (p. 62). Finalmente, percebe-se que esse padrão se repetiu de forma bastante similar em todas as escolas e municípios (p. 64), o que nos leva a crer que a homofobia é um fenômeno estrutural e sistemático presente em todos os espaços sociais - especialmente nas instituições escolares - e manifestado de maneira mais ou menos uniforme. A partir da percepção desse problema, autoridades públicas nas esferas federal, estadual e municipal têm se desdobrado e se comprometido a apoiar, elaborar e implementar políticas públicas de erradicação da homofobia nas escolas, uma vez atestada a indubitável presença dessa forma de violência nas escolas brasileiras. A existência da homofobia é ao mesmo tempo a justificativa e o alvo de combate de algumas políticas públicas que analisaremos de agora em diante.

\section{3 Homofobia e políticas públicas}

De modo geral, políticas públicas referem-se a conjuntos de ações, atividades e programas direta ou indiretamente estatais voltados a assegurar o exercício de direitos de cidadania abstratamente configurados em documentos normativos, seja por parte de toda a população, seja por parte de segmentos sociais, culturais, étnicos ou econômicos específicos. São um tipo de relação entre Estado e sociedade, em que o Estado revela os modos de agir diante de problemas existentes no interior da formação societária (CAVALEIRO, VIANNA, 2011, p. 29), ao passo que a sociedade civil se faz presente no controle dos atos de decisão do governo a fim de fiscalizar em que medida as políticas reproduzem e atendem às suas próprias necessidades (IRINEU, 2014, p. 206). Uma parcela das políticas públicas tem como alvo as minorias sociais e culturais. Por minorias, entendemos grupos de pessoas em desvantagem em

posicionar para não serem vítimas de discriminação, como ilustra a fala de professores de Maceió: Eu acho que a escola tem de brigar contra. Tem que fazer de tudo pra acabar com o preconceito. Eu acho que esse é o papel da escola, humanizar mais as pessoas, trabalhar a diversidade, o respeito, o sexo, a classe. É, tudo" (p. 297, grifo no original). No mesmo sentido apresenta o seguinte depoimento: "Quando existe qualquer forma de discriminação por parte dos colegas, nós colocamos essa discussão à tona, a discussão da discriminação das minorias, das opções. Tem que conversar, discutir o assunto, nós procuramos discutir essa relação para justamente impedir que esses alunos se sintam prejudicados ou discriminados dentro da escola (Entrevista com diretor, escola pública, Rio de Janeiro)" (p. 298, grifo no original). Outras narrações advertem-nos de que a escola não precisa ser necessariamente um espaço de opressão hostil às diferenças, e que, através de pedagogias de inclusão, é possível reverter quadros de discriminação e intolerância em ambientes cooperativos onde impera o respeito mútuo. A título de exemplo, confiramos a fala de uma professora em um grupo focal numa escola pública de Porto Alegre: "No ano passado, eu tinha cinco adolescentes gays assumidos, três lésbicas assumidas na sala de aula, e todos eles com o maior respeito de toda turma. Foram líderes de turma e botavam a turma para frente. Sem nenhum problema" (p. 292, grifo no original). 
pelo menos um campo da vida social, política, cultural ou econômica, devido ao porte de marcadores como raça, gênero, identidade de gênero, sexualidade, origem étnica ou classe social. Tais desvantagens são obstáculos para que essas pessoas exerçam os mais básicos direitos fundamentais, especialmente direitos sociais, econômicos e culturais como educação, segurança, moradia, trabalho e respeito de suas práticas e identidades culturais; essas desvantagens são contornáveis ou pelo menos atenuáveis através de contundentes ações colaborativas do Estado e da sociedade civil. A nomenclatura envolvendo as subespécies de políticas públicas é vasta e encontra divergências entre autoras e escolas de pensamento, a depender da perspectiva adotada por cada um. Por exemplo, há registro na literatura jurídicosociológica de termos como ações afirmativas e políticas de reconhecimento para referir-se a políticas públicas voltadas a grupos minoritários.

Ações afirmativas carregam uma conotação de medidas elaboradas e executadas no intuito de incluir determinados grupos que, por razões históricas de exclusão causada por processos políticos e sociais, encontram-se carentes do acesso a bens e oportunidades fundamentais e da tutela estatal. Promovem um aumento da diversidade na composição dos quadros de instituições de ensino, carreiras públicas e determinadas profissões, com vistas a atender determinados propósitos sociais (SANDEL, 2013, p. 213). Seu uso está disseminado na literatura estadunidense ${ }^{42}$ (affirmative actions) principalmente a partir da atuação da Suprema Corte dos EUA em demandas por igualdade racial. ${ }^{43}$ São afirmativas no sentido de que se apropriam das características utilizadas para negar o acesso ao tratamento igualitário justamente no intuito de incluir mediante a afirmação dos mesmos estigmas, de sua utilização estratégica e seletiva segundo a técnica da discriminação reversa. Conceituação precisa pode ser encontrada na Convenção para a Eliminação de Todas as Formas de Discriminação Racial, da Organização das Nações Unidas, ratificada pelo Brasil em 1968, segundo a qual ações afirmativas são:

medidas especiais e concretas para assegurar como convier o desenvolvimento ou a proteção de certos grupos raciais de indivíduos pertencentes a estes grupos com o

\footnotetext{
${ }^{42}$ Mas ao contrário do que se costuma pensar, as ações afirmativas têm origem na Índia, país marcado por uma profunda divisão social em castas e por uma rígida estratificação social. Foram instrumentalizadas pelo Government of India Act de 1935, aprovado por importantes lideranças indianas que incluíam o pacifista Mahatma Gandhi.

${ }^{43}$ No Brasil, o Supremo Tribunal Federal em diversas oportunidades confirmou a constitucionalidade das políticas de ação afirmativa. Entre os vários precedentes, podem ser mencionados a MC-ADI 1.276-SP, Rel. Min. Octávio Gallotti; a ADI 1.276/SP, Rel. Min. Ellen Gracie; o RMS 26.071, Rel. Min. Ayres Britto; a ADI 1.946/DF, Rel. Min. Sydnei Sanches e a MC-ADI 1.946/DF, Rel. Min. Sydnei Sanches. Sua mais eminente aceitação deu-se em 2011, no paradigmático julgamento da ADPF 186, de relatoria do Min. Ricardo Lewandowski, em que se julgou constitucional a políticas de cotas para negros da Universidade de Brasília.
} 
objetivo de garantir-lhes, em condições de igualdade, o pleno exercício dos direitos do homem e das liberdades fundamentais (art. $2^{\circ}$, II, grifamos).

Uma crítica pertinente ao conceito leva em conta a própria filosofia que está por detrás de sua edificação. A ideia de ações afirmativas não problematiza as identidades forjadas nos processos de exclusão que ela própria busca combater; ao invés disso, preconiza uma inclusão daquilo tido intrinsecamente como diferente, como se identidades sociais se tratassem de essências, deixando intocado o próprio problema da definição de raças, sexos, sexualidades etc. Nesse sentido, é possível notar que a teoria das ações afirmativas compactua de um conceito essencialista de identidade. Pensando nessa distinção, Nancy FRASER (1997, p. 19) opõe políticas afirmativas e políticas transformativas: além de corrigir resultados inequitativos, políticas transformativas defendem a reconstrução do marco geral implícito que as origina, de acordo com um método desconstrutivista. No caso de políticas públicas para o segmento LGBT, políticas transformativas buscariam, em contraposição a uma política de exaltação da identidade gay, desconstruir a dicotomia heterossexual/ homossexual a fim de desestabilizar todas as identidades sexuais fixas. Coerentemente com a posição que já vimos tomando desde as elucubrações sobre o problema da homofobia, defendemos que políticas transformativas $^{44}$ são tanto mais necessárias quanto mais adequadas para atacar a cultura da heteronormatividade em se âmago. Por esse motivo, para tratar de problemas gerados pela homofobia, preferimos a ideia de política de reconhecimento à de ação afirmativa.

Políticas de reconhecimento advogam que toda pessoa deve ser reconhecida pelas suas identidades únicas e merecer igual respeito e consideração na base do tratamento conferido pelo Estado. Estão intimamente ligadas a políticas de diferença: políticas que não tendem à assimilação, ao nivelamento, à igualação substancial dos indivíduos e grupos, mas à garantia de sua igual respeitabilidade social e de seu igual acesso a bens, oportunidades e direitos socialmente fundamentais. A formulação mais eminente deste conceito foi esboçada por Charles TAYLOR (1994) em suas críticas comunitaristas ao liberalismo e ao

\footnotetext{
${ }^{44}$ No mesmo sentido, Leandro COLLING (2013) chama a atenção para a inadequação das políticas afirmativas no que se refere às sexualidades subalternizadas. Colling propõe políticas da diferença que enfoquem políticas transformativas no campo da cultura - ao lado das lutas que se dão no marco legal -, através do questionamento dos binarismos e da afirmação de identidades. Isso porque a afirmação de identidades cria hierarquias dentro da própria comunidade LGBT, cria uma disputa entre identidades essencializadas trans, bi, homo, lesbo, e fecha o espaço político para identidades que se recusam a se encaixar nessas categorias estanques. "Ao concentrar as nossas forças quase exclusivamente em políticas afirmativas, começamos a disputar espaço e poder com as demais pessoas subalternizadas, inclusive dentro da própria sigla LGBT” (p. 420). As ações transformativas na educação são típicas políticas no campo da cultura (p. 422).
} 
multiculturalismo liberal, lançando mão de uma perspectiva identitária também essencialista. Por esse motivo, a mesma crítica pode ser aplicada com base em FRASER (1997). Não obstante, uma política de reconhecimento, em contrapartida, não precisa ser necessariamente identitária. $\mathrm{O}$ viés afirmativo ou transformativo, aplicado à perspectiva do reconhecimento, gera dois conjuntos de medidas bastante distintos: de um lado, aplicada a perspectiva afirmativa, tem-se o programa de ação do chamado multiculturalismo central, que apoia a diferenciação dos grupos e promove uma ressignificação superficial do respeito entre as identidades e grupos existentes; de outro, tem-se o programa de ação desconstrucionista do pós-estruturalismo, que desestabiliza a diferenciação entre grupos através da profunda reestruturação das relações de reconhecimento (FRASER, 1997, p. 25).

Admitimos, portanto, que políticas públicas de combate à homofobia - ou qualquer outra forma de preconceito e discriminação - devem ter em mente uma perspectiva transformativa de reconhecimento. Feita essa ressalva e tendo em mão este primeiro critério, cabe-nos analisar a adequação das políticas que vêm sendo pensadas, promulgadas e executadas pelo Estado brasileiro até o momento. Antes de mais nada, é necessário fazer um mapeamento dessas políticas, no intuito de determinar: quais são, quem são os sujeitos envolvidos na sua elaboração e na sua destinação, quais são suas justificativas, objetivos e métodos de ação, que êxito ou fracasso tiveram até então, qual perspectiva teórica, política e ideológica perpassa por elas.

O enfrentamento da discriminação por orientação sexual, apesar de realizado de forma engajada há décadas por movimentos sociais organizados, tem história recente enquanto política de governo no Brasil. A primeira manifestação governamental específica para tratar do combate à homofobia em forma de políticas públicas foi o Programa Brasil Sem Homofobia (PBSH) de 2004, lançado durante o primeiro mandato do governo Lula/ PT; e a primeira manifestação específica no que concerne ao combate à homofobia no âmbito da educação foi o Projeto Escola Sem Homofobia (PESH) de 2011, lançado durante o primeiro mandato do governo Dilma Rousseff/ PT. Antes de passarmos à análise do PBSH e do PESH, vejamos seus antecedentes históricos.

O tema da discriminação homofóbica foi suscitado pela primeira vez em nível mundial em foro das Nações Unidas, durante a Conferência Mundial de Beijing (1995) pela delegação da Suécia. Nessa oportunidade, delegações islâmicas objetaram a proposta de modo a impedir o consenso necessário para sua aprovação. O debate foi retomado durante a preparação para a 
Conferência Mundial Contra o Racismo, a Discriminação Racial, a Xenofobia e Formas Conexas de Intolerância, a ser realizada em Durban, na África do Sul, em 2001. Durante os ritos preparatórios pra a Conferência de Durban, o Brasil levou o tema à Conferência Regional das Américas, realizada em Santiago do Chile, em 2000, o qual acabou sendo incorporado sob a forma de discriminação racial agravada no texto da Declaração de Santiago, pela qual os Estados sul-americanos subscreventes se comprometiam a prevenir e reprimir manifestações discriminatórias de cunho homofóbico. Durante a Conferência de Durban, o Brasil finalmente introduziu o tema em plenária, porém a proposta de inclusão da discriminação por orientação sexual nas formas de discriminações que agravam o racismo, embora apoiada por muitas delegações, especialmente europeias, não entrou para o texto final da Declaração de Plano e Ação da Conferência de Durban.

A despeito da derrota internacional, os debates em âmbito nacional prosseguem: na segunda versão do Programa Nacional de Direitos Humanos (PNDH II) de 2002, há uma seção dedicada ao assunto, contendo 15 ações a serem adotadas pelo governo brasileiro para a sensibilização da sociedade em direção à garantia dos direitos das LGBT e ao combate à discriminação por orientação sexual. Em 2001 é criado o Conselho Nacional de Combate à Discriminação (CNCD), em atendimento às recomendações emanadas da Conferência de Durban, cujas pautas incluíam o combate à discriminação com base em orientação sexual, composto com a participação de representantes dos segmentos LGBT. Apenas em 2010 seria criado o Conselho Nacional LGBT. Dentro do CNCD, criaram-se, em 2003, uma Comissão Temática para receber denúncias de violações de direitos humanos com base na orientação sexual, além de um Grupo de Trabalho destinado à elaboração do Programa Brasileiro de Combate à Violência e à Discriminação a Gays, Lésbicas, Travestis, Transgêneros e Bissexuais (GLBT) e Promoção da Cidadania Homossexual (CONSELHO, 2004, pp. 12-13). Trata-se do Programa Brasil Sem Homofobia, o qual nos dedicaremos a analisar no primeiro momento.

\subsubsection{Programa Brasil Sem Homofobia (PBSH- 2004)}

O Brasil Sem Homofobia (Programa de Combate à Violência e à Discriminação contra $G_{L B T^{45}}$ e de Promoção da Cidadania Homossexual) foi lançado em atendimento à

\footnotetext{
${ }^{45}$ Note-se que na época de publicação do documento que define o PBSH, a sigla GLBT era oficialmente adotada pelos movimentos organizados. Esse quadro foi alterado em 7 de junho de 2008, quando na $1^{\text {a }}$ Conferência
} 
diretriz "elaboração do plano de combate à discriminação contra homossexuais", prevista no Plano Plurianual 2004-2007 do Programa Direitos Humanos, Direitos de Todos, com objetivo de promover a cidadania de LGBT a partir da equiparação de seus direitos e do combate à violência e à discriminação homofóbicas (CONSELHO, 2004, p. 11). Apesar de a Secretaria Especial de Direitos Humanos da Presidência da República ser o órgão responsável pela sua articulação, implantação e avaliação, neste Programa estão envolvidos demais Ministérios e Secretarias do Governo Federal. Ressalte-se que sua elaboração contou com a participação direta ${ }^{46}$ de membros do segmento LGBT (Ibid., p. 27). O PBSH adota como princípios a perspectiva da não-discriminação por orientação sexual, do enfrentamento de todas as formas de discriminação e violência e da promoção dos direitos de LGBT nas políticas públicas e estratégicas do Governo Federal, os quais devem ser observados e concretizados através do estabelecimento de um compromisso entre o Estado e toda a sociedade brasileira (Ibid., pp. 11-12).

O Programa justifica-se enquanto mais um instrumento da luta pela cidadania LGBT já empreendida por associações e grupos de ativistas - atualmente, há cerca de 140 grupos espalhados pelo país - desde o início da década de 1980.

\begin{abstract}
Atuando em áreas como a saúde, a educação e a justiça, os homossexuais brasileiros organizados têm enfrentado a histórica situação de discriminação e marginalização em que foram colocados no seio da sociedade brasileira. E, para além da luta pelo reconhecimento de seus legítimos direitos civis, sociais e políticos, sua atuação tem se desdobrado em um notável engajamento no enfrentamento de graves problemas de interesse público, sendo casos exemplares sua mobilização em torno da luta contra o HIV/AIDS no País e do combate à violência urbana. Em ambos os contextos, têm visto surgir uma eficiente parceria entre grupos GLBT e órgãos de saúde e de segurança pública municipais, estaduais e federais (Ibid., p. 15).
\end{abstract}

\footnotetext{
Nacional de Gays, Lésbicas, Bissexuais, Travestis e Transexuais decidiu-se padronizar a nomenclatura utilizada pelos movimentos sociais e pelo governo, a qual passou a ser LGBT: lésbicas, gays, bissexuais, travestis e transexuais. A mudança teria ocorrido no intuito de dar maior destaque à atuação das mulheres lésbicas no seu duplo trabalho contra o heterossexismo e o machismo. Conferir: http://g1.globo.com/Noticias/Brasil/0,,MUL593295-5598,00MOVIMENTO+GLBT+DECIDE+MUDAR+PARA+LGBT.html. Acessado em 20/03/2016.

${ }^{46}$ A principal forma de diálogo entre o MEC e os grupos sociais organizados para a construção de agendas de políticas tem sido a chamada política de concertação, através da qual ampliam-se os mecanismos de participação da sociedade civil por meio de fóruns, seminários, conferências, audiências públicas etc. Desse modo reúnem-se especialistas e profissionais da educação, autoridades locais e representantes de movimentos e organizações sociais interessados no avanço dessa agenda. Contudo, os programas que preveem a perspectiva da diversidade estão fragmentados e não articulados, o que prejudica sua efetivação e lança novos desafios (CAVALEIRO, VIANNA, 2011, p. 39).
} 
Embasa-se, ainda, no reconhecimento legal $^{47}$ da homofobia como forma de discriminação e na contundente atuação do Poder Judiciário ${ }^{48}$ no sentido de garantir os direitos de LGBT mesmo a despeito de lacuna legislativa. Faz menção às diferentes formas de violência cometidas contra gays, lésbicas, bissexuais e, principalmente, travestis e transgêneros, desde a violência letal, passando por formas de violência consideradas menos graves ou menos alarmantes, como a humilhação, a ofensa e a extorsão. Traduz-se numa “inequívoca sinalização de que os poderes públicos e a sociedade brasileira precisam interromper a longa sequência de cumplicidade ou indiferença em relação a fenômenos e estruturas sociais e institucionais ligados ao sexismo e à homofobia" (SECRETARIA, 2009, p. 23).

Doze anos após seu lançamento, o PBSH tem enfrentado dificuldades para implementar suas políticas: ${ }^{49}$ suas atividades têm sido dispersas e sem continuidade, envolvendo muito mais as próprias ONGs de ativistas do que os órgãos estatais. Contudo, algumas ações foram efetivamente realizadas: apoio a projetos de ONGs, universidades públicas e centros de saúde pública; capacitação de militantes, ativistas, pesquisadoras universitárias, professoras da rede pública; criação de centros de referência em direitos humanos e combate a crimes de homofobia; e a realização da I Conferência Nacional de Políticas Públicas para Lésbicas, Gays, Bissexuais, Travestis e Transexuais, em junho de 2008

47 "Em que pese a Constituição Federal de 1988 não contemplar a orientação sexual entre as formas de discriminação, diferentes constituições estaduais e legislações municipais vêm contemplando explicitamente esse tipo de discriminação. Atualmente, a proibição de discriminação por orientação sexual consta de três Constituições Estaduais (Mato Grosso, Sergipe e Pará), há legislação específica nesse sentido em mais de cinco estados (RJ, SC, MG, SP, RS) e no Distrito Federal e mais de oitenta municípios brasileiros têm algum tipo de lei que contempla a proteção dos direitos humanos de homossexuais e o combate à discriminação por orientação sexual" (CONSELHO, 2004, p. 16).

${ }^{48}$ Através do Poder Judiciário têm eclodido enormes avanços na defesa dos direitos sexuais, tais como a extensão dos benefícios de pensão por morte e auxílio-reclusão aos casais homossexuais, determinados em 2001, o reconhecimento do direito sobre a guarda dos filhos criados em comum com o companheiro ou a companheira (como o caso da guarda do filho da cantora Cássia Eller, após sua morte) e, na esfera criminal, o combate aos crimes de ódio (conferir a sentença de condenação pelo brutal assassinato de Édson Néris, proferida pelo juiz Luís Fernando Camargo de Barros Vidal) (ver CONSELHO, 2004, p.16). Esses avanços se deram anteriormente ao julgamento da ADI 4277, que tratou do reconhecimento da constitucionalidade da união entre pessoas do mesmo sexo em sede de controle concentrado de constitucionalidade.

${ }^{49}$ O PBSH instituiu ações centradas em quatro eixos: a) apoio a projetos que atuam na promoção da cidadania LGBT ou no combate à homofobia, b) capacitação de profissionais, ativistas e representantes LGBT que atuam na defesa dos direitos humanos, c) disseminação de informações sobre direitos e d) incentivo à denúncia de violações de direitos humanos (CONSELHO, 2004, p. 11). Seu programa de ações opera em 11 níveis: I) articulação da política de promoção dos direitos de homossexuais; II) legislação e Justiça; III) cooperação internacional; IV) direito à segurança: combate à violência e à impunidade; V) direito à educação: promovendo valores de respeito à paz e à não-discriminação por orientação sexual; VI) direito à saúde: consolidando um atendimento e tratamentos igualitários; VII) direito ao trabalho: garantindo uma política de acesso e de promoção da não-discriminação por orientação sexual; VIII) direito à cultura: construindo uma política de cultura de paz e valores de promoção da diversidade humana; IX) política para a juventude; X) política para as mulheres; XI) política contra o racismo e a homofobia (Ibid., pp. 19-26). Prevê um monitoramento sistemático e periódico das ações previstas, realçando o protagonismo do CNCD (Ibid., p. 28). 
(IRINEU, 2014, p. 199). De modo geral, seus resultados ainda são incipientes e clamam pela continuidade da luta dos movimentos LGBT para garantir a visibilidade de suas demandas e seu provimento por parte do Estado.

No que se refere à Educação, campo que é o foco deste trabalho, vale a pena reproduzir o capítulo $\mathrm{V}$, tópico 23 , do rol de ações previstas:

Elaborar diretrizes que orientem os Sistemas de Ensino na implementação de ações que comprovem o respeito ao cidadão e à não-discriminação por orientação sexual:

. Fomentar e apoiar curso de formação inicial e continuada de professores na área da sexualidade;

. Formar equipes multidisciplinares para avaliação dos livros didáticos, de modo a eliminar aspectos discriminatórios por orientação sexual e a superação da homofobia;

. Estimular a produção de materiais educativos (filmes, vídeos e publicações) sobre orientação sexual e superação da homofobia;

- Apoiar e divulgar a produção de materiais específicos para a formação de professores;

. Divulgar as informações científicas sobre sexualidade humana;

. Estimular a pesquisa e a difusão de conhecimentos que contribuam para o combate à violência e à discriminação de GLBT;

- Criar o Subcomitê sobre Educação em Direitos Humanos no Ministério da Educação, com a participação do movimento de homossexuais, para acompanhar e avaliar as diretrizes traçadas (CONSELHO, 2004, pp. 22-23, grifamos).

O PBSH conferiu especial ênfase à ação educacional como instrumento de combate à homofobia. Nesse diapasão, vejamos um breve apanhado histórico a respeito das discussões brasileiras sobre a interseção entre sexualidade e educação.

\subsubsection{Educação inclusiva no Brasil e diversidade sexual}

Como seu próprio nome sugere, a escola pública é pública - e esta observação, por mais pleonástica que possa parecer, não é nada trivial. Partindo desse pressuposto, é dever da escola e das políticas públicas na área educacional garantirem o acesso e a inclusão ${ }^{50}$ de todos

\footnotetext{
${ }^{50}$ Fernando SEFFNER (2009, p. 134) estabelece uma importante distinção entre acesso e inclusão. A ideia de acesso conduz à mera garantia de uma vaga em sala de aula para a aluna, a qual terá de se adaptar às dinâmicas escolares já existentes a duras penas, sem que a escola tome um passo em direção a seu acolhimento. A ideia de inclusão, mais do que isso, sugere a tomada de ações de acolhida e de posições de verdadeiro interesse pelos novos públicos de alunas, pelos seus perfis, suas questões e seus problemas, inclusive indagando em que medida
} 
os sujeitos presentes na plural e multicultural sociedade brasileira, especialmente daqueles que mais precisam dos conhecimentos escolares para alcançar uma melhor situação de vida, os quais são justamente os historicamente excluídos das instituições escolares. Os esforços em direção à inclusão, sintetizados e incorporados nos famigerados slogans "escola inclusiva", "pedagogia inclusiva", "educação para todos", "Pátria Educadora" etc., têm em mente que determinados grupos de pessoas estão mais frequentemente fora do espaço escolar, por motivos diversos, tais como pessoas pobres, negras, de idade mais avançada, portadoras de necessidades especiais, gays, lésbicas, transexuais e travestis.

A quase completa universalização da educação básica conquistada pelo país trouxe esses sujeitos para o ambiente escolar, o que gerou forte impacto em suas estruturas: impactos no nível dos temas e conteúdos a serem ensinados, das regras de conduta e do convívio escolar. Afinal, como garantir o igual respeito e a igual atenção a um público tão plural que deve ao mesmo tempo ser incluído e ter sua individualidade respeitada? Essas discussões inicialmente se traduzem em termos de método pedagógico. Em patamares abstratos e genéricos, dificilmente uma profissional da educação seria contra a ideia de inclusão, cenário que muda tão logo passemos a pensar a respeito de como operacionalizá-la. Nesse âmbito, discute-se inclusive sobre as pessoas que "merecem” ser incluídas e aquelas que não. Nesse momento do discurso é que os preconceitos e estigmas internalizados sobre as orientações sexuais de gays, lésbicas, travestis e transexuais pelas próprias autoridades escolares e professoras vêm à tona. Habitualmente, o valor depreciativo e a conclusão estereotipada sobre a imagem do "homossexual" com um possível perturbador da ordem, corruptor das demais alunas, como moralmente desviante ou um abusador sexual em potencial, são alegadas como argumento para dizer que essas pessoas só podem ou merecem ser incluídas caso mudem de comportamento. Gera-se assim uma verdadeira exclusão na inclusão (SEFFNER, 2009, pp. 126-127).

Acontece que, devido a seu caráter público, toda pessoa merece estudar na escola, cabendo a esta organizar maneiras para incluir justamente aquelas pessoas que têm mais dificuldade de acesso e permanência, por meio da criação de condições favoráveis. Tradicionalmente, a escola brasileira tem servido como instrumento de exclusão da cidadania,

a escola deverá alterar suas próprias dinâmicas para também se adaptar a esses novos públicos, quais novas questões são trazidas para debate e como a escola pode tematizá-las adequadamente. 
de modo que alguns autores sugerem que há um projeto das elites ${ }^{51}$ consistente em excluir as camadas mais pobres da sociedade dos meios de obter capital educacional e, portanto, cidadania, mantendo assim o status quo e os privilégios classistas dele decorrentes. E o Estado, agindo em benefício daqueles grupos que detêm o poder de influência e de barganha suficientes para cooptá-lo, direciona quais crenças e valores serão proliferados pelo ensino público. Assim se manifesta Fernando SEFFNER (2009, p. 130) a respeito dos supostos "aliados da exclusão":

(...) num país onde tão poucos têm acesso a tantos benefícios e riquezas, é bastante plausível pensar que estes poucos, que detêm grande influência sobre o funcionamento do aparelho estatal e particularmente da mídia, queiram ter a escola como aliada no sentido de manter tal situação, engrossando o contingente dos excluídos, e jogando neles a culpa da própria exclusão.

Em termos legais, o princípio da educação inclusiva no Brasil está amparado na Lei de Diretrizes e Bases da Educação Nacional ${ }^{52}$ (LDB - Lei no 9394/96), que assegura o direito à escola de todas as pessoas sem discriminação de singularidades ou características específicas de indivíduos ou grupos humanos. Tais discriminações não são definidas em termos mais exatos e, desde então, há uma constante batalha pela inclusão da discriminação com base em orientação sexual na lista de discriminações vedadas pela LDB, ou pelo desdobramento do princípio da não discriminação em ações de orientação das políticas públicas na área de educação. Posteriormente, em atenção ao comando constitucional que determina que o Estado elabore parâmetros ${ }^{53}$ para as ações educativas, dentro do marco de centralização estatal da definição dos conteúdos curriculares da educação básica, o MEC lançou oficialmente os Parâmetros Curriculares Nacionais (PCN) em 1997. Adotando a perspectiva da "pluralidade cultural", os PCN propunham uma visão crítica sobre as relações sociais discriminatórias e

\footnotetext{
${ }^{51}$ Conferir, por todos, Darcy RIBEIRO (1977). Depois de um breve apanhado histórico sobre como se deu o processo de universalização da educação no Brasil, e após uma série de argumentos persuasivos, Darcy Ribeiro conclui: "Cremos haver demonstrado até aqui que no campo da educação é que melhor se concretiza a sabedoria das nossas classes dominantes e sua extraordinária astúcia na defesa de seus interesses. De fato, uma minoria tão insignificante e tão claramente voltada contra os interesses da maioria, só pode sobreviver e prosperar contando com enorme sagacidade, enorme sabedoria, que é preciso compreender e proclamar" (p. 9). "Em consequência, a crise educacional do Brasil da qual tanto se fala, não é uma crise, é um programa. Um programa em curso, cujos frutos, amanhã, falarão por si mesmos" (p.10).

${ }^{52}$ A "atenção à equidade" revelada na LDB surgiu num contexto de intensa mobilização internacional em torno do tema da importância da educação para a "promoção da equidade social, pressupondo igualdade de oportunidades, compensação das diferenças, desenvolvimento equilibrado e coeso do corpo social". Ente 1993 e 1996 a UNESCO havia realizado a conferência Educação para o século XXI, em que definia como um dos três grandes desafios para o século "o convívio democrático, entendido como vida em comunidade" (CAVALEIRO, VIANNA, 2011, p. 32).

${ }^{53} \mathrm{O}$ art. 210 da Constituição dispõe: "Serão fixados conteúdos mínimos para o ensino fundamental, de maneira a assegurar formação básica comum e respeito aos valores culturais e artísticos, nacionais e regionais".
} 
excludentes que permeiam a sociedade brasileira. Embora não se possa negar que os PCN consistiram em um avanço a respeito da oficialização dos temas de gênero e sexualidade nos currículos escolares, observa-se a subordinação da temática ao viés corpo-saúde-doença. Além do que, malgrado se refira ao tema transversal "orientação sexual", os PCN são silenciosos quanto à "diversidade sexual" (CAVALEIRO, VIANNA, 2011, pp. 33-24). Apesar de surgido em um contexto de profunda mobilização social, o Plano Nacional de Educação (PNE) de 2001 (Lei $n^{\circ}$ 10172) foi silente em torno do tema da diversidade de orientação afetivo-sexual.

A implementação de ações voltadas à promoção da equidade de identidade de gênero e orientação sexual no Brasil ${ }^{54}$ na área da educação, em nível de ações governamentais em âmbito federal, encontra respaldo no Programa Nacional de Direitos Humanos II (PNDH II, de 2002), no Programa Brasil Sem Homofobia (PBSH, de 2004), no Plano Nacional de Educação em Direitos Humanos (PNEDH, de 2006), no Plano Nacional de Promoção da Cidadania e Direitos Humanos LGBT (PNPCDH/LGBT, de 2009) e no Projeto Escola Sem Homofobia (PESH, de 2011).

O PNDH II, elaborado em 2001 para ser implementado a partir de 2002, destaca direitos à liberdade de expressão, de crença e culto e de orientação sexual. Dentre outras medidas, propõe apoiar uma emenda à Constituição Federal que inclua a garantia do direito à livre orientação sexual e a proibição da discriminação por orientação sexual. Em relação a medidas especialmente voltadas à educação, propõe:

\footnotetext{
- estimular a formação, no âmbito federal, estadual e municipal, de programas governamentais destinados a assegurar a igualdade de direitos em todos os níveis, incluindo saúde, educação e treinamento profissional, trabalho, segurança social, propriedade e crédito rural, cultura, política e justiça;

$(\ldots)$

- apoiar programas de capacitação de profissionais de educação, policiais, juízes e operadores do direito em geral para promover a compreensão e a consciência ética
}

\footnotetext{
${ }^{54}$ Inicialmente, as políticas públicas relacionadas à homossexualidade no Brasil eram voltadas à prevenção da AIDS e demais DSTs. A transição de um modelo focado na saúde pública para um modelo mais amplo, inspirado pela perspectiva dos direitos humanos e da cidadania, foi lenta e gradual e só passou a ter mais peso no início deste século. Por exemplo, o tratamento da sexualidade como tema transversal, nos Parâmetros Curriculares Nacionais do Ensino Fundamental de 1996, ainda gravita fortemente em torno da preocupação do combate às DSTs. São pioneiras as ações em âmbito local da Secretaria Municipal de Educação da cidade de São Paulo, que entre 1989 e 1992 promoveu cursos de formação de professores e professoras em que as temáticas relativas a gênero e sexualidade não tinham uma perspectiva disciplinadora de manutenção dos valores conservadores da heteronormatividade e da conjugalidade heterossexual. Inspirada por esses referenciais, a Secretaria Municipal de Porto Alegre desenvolveu o projeto "Sexo em Debate na Escola" em 1990 (SECRETARIA, 2007, pp. 14-15; CAVALEIRO, VIANNA, 2011, pp. 34-35).
} 
sobre as diferenças individuais e a eliminação dos estereótipos depreciativos com relação aos LGBT;

(...)

. incentivar programas de orientação familiar e escolar para a resolução de conflitos relacionadas à livre orientação sexual, com o objetivo de prevenir atitudes hostis e violentas (BRASIL/MER, apud SECRETARIA, 2007, p. 23).

O PNEDH/ 2006, assinado pelo Ministério da Educação e pela Secretaria Especial de Direitos Humanos e elaborado pelo Comitê Nacional de Educação e Direitos Humanos, aduz a conexão intrínseca entre educação em direitos humanos e valorização da diversidade. Dentre diversas estratégias, prevê, para a Educação Básica, o fomento da “inclusão, no currículo escolar, das temáticas relativas a gênero, identidade de gênero, raça e etnia, religião, orientação sexual, (...) assegurando a formação continuada dos(as) trabalhadores(as) da educação para lidar criticamente com esses temas" (BRASIL/CNDH/MEC apud SECRETARIA, 2007, p. 25).

O PNPCDH-LGBT resultou da proposta número 36 aprovada na $1^{\text {a }}$ Conferência Nacional GLBT, ocorrida em Brasília entre 5 e 8 de junho de 2008, e trouxe diretrizes e ações para a elaboração de políticas públicas voltada para esse segmento (SECRETARIA, 2009, p. 9). Destacam-se uma série de metas e estratégias ${ }^{55}$ voltadas para a tematização da

\footnotetext{
${ }^{55}$ Destacamos: Estratégia 1 - Promoção e socialização do conhecimento sobre o tema LGBT: "1.1.3. Estimular e incluir as temáticas de gênero e raça/etnia nos currículos universitários, nas atividades de ensino, pesquisas de extensão, sem excluir nenhum campo do saber ou limitar a cursos da área da saúde". Competência do MEC, para os anos de 2010/2011. Estratégia 2 - Formação de atores no tema LGBT: "1.2.2. Criar um projeto de cooperação público-governamental de extensão nas escolas públicas, utilizando produções artístico-culturais com temática de sexualidade, diversidade sexual e identidade de gênero, com recorte de raça e etnia, como forma de educar para a cidadania e inclusão". Competência do Minc e do MEC para o biênio 2010/2011. [...] "1.2.17. Ampliar o conhecimento sobre a dimensão ideológica do racismo, sexismo e lesbofobia". Competência da Secretaria Especial de Políticas para as Mulheres (SPM), para o ano de 2009. Estratégia 3 - Defesa e proteção dos direitos da população LGBT: "1.3.1. Inserir nos livros didáticos a temática das famílias compostas por lésbicas, gays, bissexuais, travestis e transexuais, considerando recortes de raça/etnia, orientação sexual, identidade de gênero e socioeconômica, os novos modelos de famílias homoafetivas, com ênfase nos recortes de raça/etnia, orientação sexual e identidade de gênero". Competência do MEC para o ano de 2011. Estratégia 4 - Sensibilização e mobilização de atores estratégicos e da sociedade para a promoção da cidadania e dos direitos humanos de LGBT: "1.4.1. Estimular e fomentar a criação e o fortalecimento de instituições, grupos e núcleos de estudos acadêmicos, bem como a realização de eventos de divulgação científica sobre gênero, sexualidade e educação, com vistas a promover a produção e a difusão de conhecimentos que contribuam para a superação da violência, do preconceito e da discriminação em razão de orientação sexual e identidade de gênero. [...] 1.4.2. Produzir e/ou estimular a confecção e a divulgação de materiais didáticos e paradidáticos e de materiais específicos para a formação de profissionais da educação para a promoção do reconhecimento da diversidade de orientação sexual e identidade de gênero, inclusive em linguagens e tecnologias que contemplem as necessidades das pessoas com deficiência. [...] 1.4.3. Produzir, apoiar e divulgar pesquisas que analisem concepções pedagógicas, currículos, rotinas, atitudes e práticas adotadas no ambiente escolar diante da diversidade de orientação sexual e de identidade de gênero, para contribuir para a implementação de políticas educacionais voltadas para a superação do preconceito, da discriminação e da violência sexista e homofóbica. [...] 1.4.6. Incluir nos programas de
} 
discriminação sexual na educação. Observa-se, todavia, que o Plano LGBT, diferentemente do PBSH, foi sistematizado por uma equipe técnica constituída de servidoras de todos os ministérios, sem contar com a participação de representantes dos movimentos sociais, fato que indicaria tanto uma profissionalização da discussão governamental quanto os limites do processo de participação política e de controle social (IRINEU, 2014, p. 202). Suas ações foram monitoradas pelo Conselho Nacional LGBT e avaliadas na II Conferência Nacional LGBT, realizada em dezembro de 2011.

O tema da diversidade também foi insistentemente discutido na VI Conferência Nacional de Educação (CONAE) de 2010. No documento gerado, destacam-se grandes avanços, dentre os quais a garantia da discussão do tema na formação inicial e continuada docente; a reorganização curricular nacional com a participação das agentes e das entidades educacionais interessadas; a revisão dos critérios de avaliação dos livros didáticos no que tange às imagens e aos modelos de família neles contidos; o debate sobre o uso dos nomes sociais pelas travestis e transexuais em documentos oficiais das instituições escolares; e o fomento e incentivo de pesquisas sobre gênero, sexualidade e educação (CAVALEIRO, VIANNA, 2011, p. 40).

Em último lugar, podemos apontar o Projeto de Lei do Plano Nacional de Educação (PNE), encaminhado ao Congresso Nacional em dezembro de 2010, que estabelece normas e diretrizes para a educação no decênio 2011-2020. O Congresso Nacional votou o Projeto de Lei $n^{\circ}$. 8035/2010, de iniciativa do Poder Executivo da República. Em dois momentos distintos, esse projeto sustentava a preocupação com o combate das desigualdades a partir da ideia de reconhecimento das identidades sexuais excluídas. $\mathrm{O}$ art. $2^{\circ}$, III, designava textualmente como objetivo da educação no Brasil "a superação das desigualdades educacionais, com ênfase na promoção da igualdade racial, regional, de gênero e orientação sexual" (grifamos). No mesmo tom, a Estratégia 3.12 da Meta 3 requeria a implementação de “políticas de prevenção à evasão motivada por preconceito e discriminação racial, por orientação sexual ou identidade de gênero, criando rede de proteção contra formas associadas de exclusão" (grifamos).

A inclusão dos termos "gênero e orientação sexual" no PL e a referência a políticas de promoção da igualdade de gênero e orientação sexual no âmbito educacional foram

distribuição de livros para as bibliotecas escolares obras científicas e literárias que abordem as temáticas de gênero e diversidade sexual para os públicos infanto-juvenis e adultos". Todas as estratégias são de competência do MEC, para o ano de 2012. 
suficientes para deflagrar uma vasta polêmica no espaço público brasileiro, o que evidencia a resistência dos grupos hegemônicos de poder para com a luta por reconhecimento de direitos das minorias e uma possível alteração do status social, jurídico e político dessas cidadãs e da própria estrutura hierárquica a ser mantida. Os grupos de pressão de ideologia conservadora conseguiram que o Senado Federal, em dezembro de 2013, aprovasse o PLC 103/2012, um substitutivo que eliminou aquilo que os conservadores chamaram equivocadamente de "ideologia de gênero", de modo que a redação do inciso III do art. $2^{\circ}$ passou a mencionar tão somente uma política generalista de combate a "toda forma de discriminação", sem nenhum comprometimento explícito com as agendas de movimentos sociais específicos. Ao final das discussões parlamentares e controvérsias pela imprensa e pelas redes informais de comunicação, a proposta inicial foi aprovada com destaques que excluíam a referência clara ao combate às discriminações de gênero e orientação sexual.

Abaixo, sintetizamos em um quadro esquemático os principais momentos em que a discussão sobre a interseção entre sexualidade e educação, no sentido da garantia dos direitos de cidadania de LGBT nas escolas através de políticas públicas em âmbito educacional, ganhou amplo destaque nacional.

Tabela 3: Linha do tempo de ocasiões relevantes para a discussão sobre sexualidade e escolas

\begin{tabular}{|c|c|c|}
\hline Ano & Evento & Motivo de repercussão \\
\hline 1995 & $\begin{array}{l}\text { Realização da Conferência Mundial da } \\
O N U \text { em Beijing, China }\end{array}$ & $\begin{array}{l}\text { Primeira proposta (rejeitada) de ação integrada em escala } \\
\text { internacional contra a discriminação com base em } \\
\text { orientação sexual. }\end{array}$ \\
\hline 1996 & $\begin{array}{l}\text { Promulgação da Lei de Diretrizes } e \\
\text { Bases da Educação Nacional (LDB) - } \\
\text { Lei no 9394/96 }\end{array}$ & $\begin{array}{l}\text { Proclama pela primeira vez em legislação nacional o } \\
\text { direito amplo e geral à escola, sem discriminações de } \\
\text { qualquer espécie. }\end{array}$ \\
\hline 1997 & $\begin{array}{l}\text { Lançamento dos Parâmetros } \\
\text { Curriculares Nacionais }(P C N)\end{array}$ & $\begin{array}{l}\text { Adotam explicitamente a perspectiva da "pluralidade } \\
\text { cultural" e se referem à adoção do estudo de sexualidade } \\
\text { nas escolas, ainda que sob o viés da prevenção de } \\
\text { doenças. }\end{array}$ \\
\hline 2000 & $\begin{array}{l}\text { Realização da Conferência Regional das } \\
\text { Américas em Santiago, Chile }\end{array}$ & $\begin{array}{l}\text { A delegação brasileira propõe (com conseguinte } \\
\text { aprovação) a inclusão da discriminação por orientação } \\
\text { sexual como forma de discriminação racial agravada. }\end{array}$ \\
\hline 2001 & $\begin{array}{l}\text { Realização da Conferência Mundial } \\
\text { Contra o Racismo, a Discriminação } \\
\text { Racial, a Xenofobia e Formas Conexas } \\
\text { de Intolerância da ONU, em Durban, }\end{array}$ & $\begin{array}{l}\text { A delegação brasileira propõe (sem lograr aprovação) a } \\
\text { inclusão da discriminação por orientação sexual como } \\
\text { forma de discriminação racial agravada. }\end{array}$ \\
\hline
\end{tabular}




\begin{tabular}{|c|c|c|}
\hline & 1 & \\
\hline 2001 & $\begin{array}{l}\text { Criação do Conselho Nacional de } \\
\text { Combate à Discriminação }(\mathrm{CNCD})\end{array}$ & $\begin{array}{l}\text { Inclui o combate à discriminação por orientação sexual } \\
\text { como pauta. }\end{array}$ \\
\hline 2002 & $\begin{array}{l}\text { Lançamento do Plano Nacional de } \\
\text { Direitos Humanos (PNDH II) }\end{array}$ & $\begin{array}{l}\text { Contém } 15 \text { ações a serem adotadas pelo governo para a } \\
\text { sensibilização social com relação às demandas LGBT. }\end{array}$ \\
\hline 2004 & 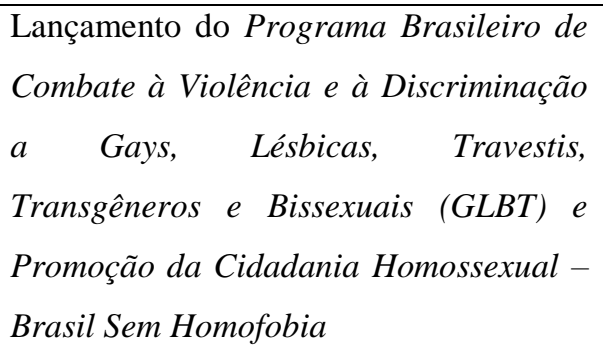 & $\begin{array}{l}\text { Primeiro programa integrado e unificado de metas e } \\
\text { estratégias para o combate à homofobia em nível } \\
\text { nacional e interinstitucional. }\end{array}$ \\
\hline 2006 & $\begin{array}{l}\text { Lançamento do Plano Nacional de } \\
\text { Educação em Direitos Humanos }\end{array}$ & $\begin{array}{l}\text { Prevê a inclusão curricular de temáticas relativas a } \\
\text { identidade de gênero e orientação sexual. }\end{array}$ \\
\hline 2009 & $\begin{array}{l}\text { Lançamento do Plano Nacional de } \\
\text { Promoção da Cidadania e Direitos } \\
\text { Humanos de Lésbicas, Gays, Bissexuais, } \\
\text { Travestis e Transexuais }\end{array}$ & $\begin{array}{l}\text { Traz diretrizes e ações para elaboração de políticas } \\
\text { públicas voltadas para o segmento LGBT, com destaque } \\
\text { para uma série de estratégias focadas na educação. }\end{array}$ \\
\hline 2010 & $\begin{array}{l}\text { Realização da VI Conferência Nacional } \\
\text { de Educação (CONAE) }\end{array}$ & $\begin{array}{l}\text { Gerou um documento em que as instituições escolares se } \\
\text { comprometiam a tomar uma série de medidas no sentido } \\
\text { de respeitar a cidadania LGBT. }\end{array}$ \\
\hline 2010 & $\begin{array}{l}\text { Criação do Conselho Nacional de } \\
\text { Combate à Discriminação e Promoção } \\
\text { dos Direitos LGBT (Decreto 7388/2010) }\end{array}$ & $\begin{array}{l}\text { Primeiro Conselho estatal criado especialmente para o } \\
\text { segmento LGBT, com a atribuição de formular e propor } \\
\text { diretrizes de ação governamental, em âmbito nacional, } \\
\text { voltadas para o combate à discriminação e à defesa dos } \\
\text { direitos de LGBT. }\end{array}$ \\
\hline 2011 & $\begin{array}{l}\text { Lançamento do Projeto Escola Sem } \\
\text { Homofobia }\end{array}$ & $\begin{array}{l}\text { Primeiro conjunto de materiais didático-pedagógicos } \\
\text { elaborado pelo MEC e voltado para professoras e alunas, } \\
\text { no intuito de desmistificar estereótipos baseados em } \\
\text { identidade de gênero e orientação sexual a fim de } \\
\text { erradicar, em longo prazo, as práticas homofóbicas } \\
\text { disseminadas na escola. No mesmo ano, o Projeto é } \\
\text { vetado (conferir seção 1.3.3). }\end{array}$ \\
\hline 2013 & $\begin{array}{l}\text { Votação do Projeto de Lei do Plano } \\
\text { Nacional de Educação (PNE) para o } \\
\text { Decênio de } 2011-2020 \text { - Lei } \mathrm{n}^{\circ} \\
8035 / 2010 \text { - no Congresso Nacional }\end{array}$ & $\begin{array}{l}\text { Aprovação do PLC 103/2012, um substitutivo que } \\
\text { retirava as menções textuais à vedação de discriminação } \\
\text { de gênero e orientação sexual. Esse evento é visto como } \\
\text { uma das grandes derrotas das mobilizações progressistas } \\
\text { neste campo. }\end{array}$ \\
\hline 2015 & $\begin{array}{l}\text { Discussão dos Planos Municipais e } \\
\text { Estaduais de Ensino em todo o território } \\
\text { nacional }\end{array}$ & $\begin{array}{l}\text { A discussão outrora em âmbito do PNE é discutida nos } \\
\text { âmbitos estadual e municipal. }\end{array}$ \\
\hline
\end{tabular}




\subsubsection{Projeto Escola Sem Homofobia (PESH - 2011)}

Como vimos, o Programa Brasil Sem Homofobia (PBSH) recomenda em seu componente V (Direito à Educação), diretriz 23, o fomento e o apoio a cursos de formação de professoras na área da sexualidade, a equipes multidisciplinares encarregadas de avaliar livros didáticos de modo a rever os aspectos discriminatórios que porventura apareçam neles, o estímulo à produção de materiais educativos para alunas e professoras, bem como a divulgação de informações científicas sobre sexualidade humana. Fica assim anunciada a tomada de posição do governo brasileiro de que a escola atua como agente responsável pela produção, reprodução e naturalização da homofobia tanto em seus conteúdos disciplinares como em suas interações interpessoais cotidianas. Em atendimento à diretriz do PBSH, o Ministério da Educação (MEC), através de recursos aprovados por Emenda Parlamentar da Comissão de Legislação Participativa, idealizou o Projeto Escola Sem Homofobia (PESH), com a colaboração de organizações da sociedade civil - ABGLT (Associação Brasileira de Gays, Lésbicas, Travestis e Transexuais), Pathfinder do Brasil, ECOS (Comunicação em Sexualidade) e Reprolatina (Soluções Inovadoras em Saúde Sexual e Reprodutiva) - para sua implementação e com a orientação técnica da Secretaria de Educação Continuada, Alfabetização e Diversidade (SECAD) ${ }^{56}$ do MEC.

A principal meta do PESH é contribuir para o entendimento e o reconhecimento da diversidade de valores presentes na sociedade brasileira, comprometendo-se com os direitos humanos e com uma forma de cidadania que inclua os direitos das pessoas LGBT (BRASIL, 2011a, pp. 8-9). Seu objetivo declarado é “alterar concepções didáticas, pedagógicas e curriculares, rotinas escolares e formas de convívio social que funcionam para manter

\footnotetext{
${ }^{56}$ A SECAD/MEC nasceu em 2004 com a incumbência de "transformar as propostas gestadas em outros programas e planos em metas voltadas para a educação" (CAVALEIRO, VIANNA, 2011, p. 37). A SECAD/MEC assume como horizonte, ao tratar das questões relativas a gênero, orientação sexual e sexualidade, uma perspectiva emancipatória focada nos direitos humanos (SECRETARIA, 2007, p. 9); desse modo, "promove políticas e atitudes didático-pedagógicas voltadas a garantir igualdade de direitos e de oportunidades a todos os indivíduos e grupos, independentemente de suas diferenças de gênero, identidade de gênero ou orientação sexual, e sem desconsiderar os nexos com a construção de tais diferenças com outros marcadores identitários igualmente legítimos" (p. 35). As medidas prioritárias da SECAD para a educação em diversidade, gênero e sexualidade estão distribuídas em três eixos de ação: $I$ ) Planejamento, gestão e avaliação, através do princípio da intersetorialidade, de modo a envolver diversos atores institucionais em suas políticas, do princípio da transversalidade, de modo a incluir a perspectiva de gênero e diversidade sexual nas políticas de todas as secretarias do MEC, e do princípio da focalização e inovação, mediante a criação de políticas específicas para o âmbito da educação profissional e tecnológica, de apoio a monografias e pesquisas, à distribuição de material didático e pedagógico e à qualificação de professores e professoras (p. 36); II) Acesso e permanência, mediante a criação de ações destinadas a ampliar o ingresso e a permanência da população LGBT em todos os níveis e modalidades de ensino, políticas de ação afirmativa voltadas a grupos específicos como transgêneros, transexuais etc. (p. 37), e III) Formação de profissionais da educação, estimulando a elaboração de projetos conjuntos, encontros e seminários (p. 38).
} 
dispositivos pedagógicos de gênero e sexualidade que alimentam a homofobia” (p. 11); “(...) a ideia é colocar em movimento um processo de transformação pessoal, cultural e social nas escolas e, por extensão, à [sic] sociedade" (p. 50).

A perspectiva teórica do PESH é desconstrucionista e transformativa: "busca-se desocultar a ordem que coloca a heterossexualidade como natural, normal e única possibilidade de os sujeitos viverem suas sexualidades, por meio de dinâmicas de trabalho que (...) favoreçam a reflexão e incentivem mudanças" (p. 12). Admite-se que a homofobia é um problema social que encontra eco na escola através das "fiscais" - tanto alunas quanto funcionárias e professoras - que vigiam e controlam as condutas e punem aquelas que ousam cruzar as fronteiras da heteronormatividade. Reconhece-se que, por conseguinte, a escola é um locus de produção e reprodução social de preconceitos já enraizados em toda a sociedade e em suas instituições. "As práticas escolares, compreendidas como intervenção pedagógica, transmitem e reproduzem modelos de comportamento, sensibilidade e racionalidade próprios da cultura, com seus respectivos recursos técnicos, emocionais e ideológicos” (p. 67).

Mas ao mesmo tempo em que a escola é ambiente de opressão, com seus mecanismos sociais transmissores de estereótipos de sexualidade e de manutenção das hierarquias de gênero, pode ser, nesta mesma medida, ambiente de resistência de identidades excluídas, mediante o questionamento das relações de poder e da análise intelectiva dos processos sociais de produção das diferenças. O PESH, reconhecendo a diversidade de identidades sexuais nas escolas e o princípio do igual respeito e da igual dignidade a ser conferida a elas, repousa no Documento da Conferência Nacional de Educação Básica, realizada em Brasília em abril de 2008, onde se lê que "só há educação, no sentido pleno do termo, se ela for inclusiva e respeitar a diversidade" (p. 79), donde surge um desafio, pois "nosso sistema escolar é regido pela norma do silêncio em relação à diversidade sexual” (p. 79). Tal é a posição da SECAD (SECRETARIA, 2007, p. 35):

As políticas educacionais precisam levar em conta as discussões acerca da função
social da escola na construção de masculinidades e feminilidades contrapostas ao
modelo convencional, masculino, heteronormativo, branco e de classe média. Não
podemos ignorar os efeitos que os processos de construção de identidades e
subjetividades masculinas, femininas, hetero, homo ou bissexuais produzem sobre a
permanência, o rendimento escolar, a qualidade da interação de todos os atores da
comunidade escolar e as trajetórias escolares e profissionais.

Inspirado por essa filosofia, o PESH instrumentaliza-se através de materiais didáticopedagógicos confeccionados com o objetivo de serem distribuídos para alunas e professoras 
do Ensino Médio em escolas da rede pública de todo o país. Esses materiais consistem em $a$ ) um caderno para orientar a atuação de professoras nos temas de diversidade sexual, orientação sexual e identidade de gênero, de superação da homofobia e de direitos das pessoas LGBT; em $b$ ) seis boletins, os chamados Boleshs (Boletins Escola Sem Homofobia), para serem trabalhados com as alunas; e em $c$ ) três audiovisuais ${ }^{57}$ para serem debatidos com as alunas.

O Caderno oferece "instrumentos pedagógicos para refletir, compreender, confrontar e abolir a homofobia no ambiente escolar" (BRASIL, 2011a, p. 13); está estruturado em três capítulos. O primeiro capítulo ("Desfazendo a confusão") apresenta e discute conceitos-chave como gênero, sexo, sexualidade, diversidade sexual e homofobia, bem como aborda a história, as conquistas e os desafios dos movimentos LGBT e sua luta por cidadania, concluindo pela importância da inserção desse grupo nas políticas públicas em vários níveis, inclusive no escolar. O segundo capítulo ("Retratos da homofobia na escola") propõe desocultar e desconstruir a homofobia no cotidiano escolar, explorando as sutilezas dos estereótipos criados em torno de LGBT e em que medida esses estereótipos, encobertos por um eloquente silêncio, alimentam práticas homofóbicas de agressão e violência no cotidiano escolar. Propugna ainda pela elaboração de um currículo que adote a transversalidade ${ }^{58}$ de modo a incluir o enfrentamento da homofobia como tema social relevante. No terceiro e último capítulo (“A diversidade sexual na escola”), o Caderno se propõe a contribuir, com reflexões e sugestões de atividades, para a elaboração de planos de ação voltados à construção de projetos político-pedagógicos $^{59}$ (PPPs) que respondam à urgência do enfrentamento da homofobia na escola. Finalmente, o Anexo 1 traz sugestões de como trabalhar com os Bolesh $^{60}$ e o Anexo 2, de como trabalhar com os audiovisuais. ${ }^{61}$

\footnotetext{
${ }^{57}$ Não poderemos nos deter na análise do conteúdo desses audiovisuais, tarefa realizada por SANTOS (2012, pp. 40-50), referência que recomendamos.

58 Temas transversais são "conteúdos de caráter social que devem ser incluídos no currículo do Ensino Fundamental não como áreas do conhecimento específicas, mas como conteúdos a serem ministrados no interior das várias áreas definidas no próprio currículo" (BRASIL, 2011a, p. 75). Significa pensar o conhecimento para além das grades curriculares, para além da transmissão de conteúdos científicos.

${ }_{59}$ PPP (projeto político-pedagógico) é "um instrumento teórico-metodológico que visa ajudar a enfrentar os desafios do cotidiano da escola, como os relacionados à orientação sexual e à identidade de gênero de estudantes e docentes" (BRASIL, 2011a, p. 83).

${ }^{60}$ Sobre os Boleshs: "São seis ao todo e constituem o material da/do estudante. O ideal é que cada estudante tenha seus próprios exemplares. Eles não têm uma estrutura fixa, mas cada número trabalha um tema importante na área dos direitos da população LGBT (o que é ser mulher e o que é ser homem; orientação sexual; diversidade sexual; homofobia; direitos; relações familiares) e tem um texto de fundo, textos menores e disparadores de jogos, além de desenhos e cartuns que não são apenas ilustrações, mas enriquecem o tema e geram reflexões" (BRASIL, 2011a, p. 15). Para ter acesso ao conteúdo dos Boleshs, sugerimos consulta ao Anexo I do Caderno Escola Sem Homofobia (Ibid., pp. 103-122).

61 "Os três audiovisuais são acompanhados por guias de discussão com sinopse, comentários e sugestões de atividades para a educadora ou o educador trabalhar os temas com a comunidade escolar. Medo de quê? e
} 
Esse material didático - conhecido midiaticamente como kit anti-homofobia - sequer chegou a ser distribuído nas escolas brasileiras. O kit deflagrou uma acalorada discussão na esfera pública, logrando grande rejeição por parte dos grupos sociais majoritários, notadamente organizações religiosas e setores da mídia e da opinião pública de inclinação conservadora. O MEC, que planejara distribuir 6 mil kits (nomeados irônica e pejorativamente de "kit gay" pelos seus opositores), acabou recuando por determinação da presidente Dilma Rousseff, que alegou, na ocasião, que o material era impróprio e que não cabia ao governo fazer "propaganda de opção sexual" nem interferir na vida privada das pessoas, ${ }^{62}$ retirando-o de circulação em 25 de maio de 2011.

Curiosamente, o material havia sido apresentado e aprovado em Seminário na Câmara dos Deputados, no dia 23 de novembro de 2010, bem como sua legitimidade havia sido confirmada em pareceres técnicos prolatados pela UNESCO, em 10 de fevereiro de 2011, pelo Conselho Federal de Psicologia, em 3 de fevereiro de 2011 e pela Procuradoria Federal dos Direitos Humanos do Cidadão, em 3 de maio de 2011 (SANTOS, 2012, p. 35, p. 61). O veto ao PESH indubitavelmente mostra a configuração das relações de poderes políticos e culturais hegemônicos naquela época, e ainda fortemente presentes hoje. Mesmo tendo sido elaborado por um governo supostamente progressista, através de suas Secretarias e Conselhos

Torpedo destinam-se especialmente a estudantes. Boneca na mochila é um material a ser usado não apenas para a formação de educadoras/es, mas também com mães, pais e familiares da comunidade escolar, e estudantes em sala de aula" (BRASIL, 2011a, p. 16). Para ter acesso à descrição dos três audiovisuais, sugerimos consulta ao Anexo II do Caderno Escola Sem Homofobia (Ibid., pp. 16-17, pp. 123-125). Adiantamos, desde já, que o conteúdo desses audiovisuais foi o principal motivo de polêmica em torno do PESH, como veremos adiante, na seção 1.4 .

62 A declaração da presidente da República Dilma Rousseff foi televisionada e pode ser vista em: https://www.youtube.com/watch?v=yuqJIDNBWBs\&feature=g-hist. Acessado em 23/10/2015. Segundo esclarecimento da ABGLT na página virtual já citada, datada de 21 de agosto de 2012, os arquivos com os conteúdos dos materiais estão retidos no MEC aguardando parecer para aprovação. Segundo e-mail enviado pelo MEC/SECADI quando solicitamos informações sobre o andamento atual do projeto, o órgão declarou que este encontra-se suspenso. Em notícia no Portal Terra, de 17 de maio de 2013, é divulgado que o MEC ainda analisava o kit anti-homofobia: “'O Ministério da Educação firmou uma parceria com o Fórum de Entidades Nacionais da Psicologia (Fenp) e dez universidades federais para debater e analisar todos os materiais educativos que abordem preconceitos, violência nas escolas e qualquer tipo de discriminação, entre eles, os materiais referentes ao Programa Escola sem Homofobia', disse o MEC em nota. No entanto, a pasta não detalhou quando essa análise será concluída. (...) Embora ainda não tenha uma definição para o projeto Escola sem Homofobia, o MEC diz que desenvolve algumas ações para combater a homofobia na escola. 'O Ministério da Educação possui estratégias e ações voltadas para a educação com relação ao acesso, permanência e sucesso escolar dos estudantes em situação de possível exclusão ou violência. No caso do combate à homofobia, tais ações visam à promoção de uma educação não sexista e anti-discriminatória, que promova o respeito à diversidade sexual, informou a pasta. Como exemplo dessas iniciativas, o ministério cita o apoio a cursos de pós-graduação em parceria com as universidades públicas para professores e gestores, a produção e divulgação de pesquisas, a inclusão da temática de forma adequada nos editais de avaliação e seleção de livros didáticos, a inclusão do debate nos currículos universitários, entre outras iniciativas sobre orientação sexual e da identidade de gênero". Por Angela Chagas, 17/05/2013, disponível em: http://noticias.terra.com.br/educacao/dois-anos-apos-veto-mecdiz-que-ainda-analisa-kit-anti-homofobia,62a3a67b302be310VgnVCM10000098cceb0aRCRD.html. Acessado em $28 / 10 / 2015$. 
em constante diálogo com organizações sociais representantes do segmento LGBT e demais interessadas, o legado político do PESH mostra que quem venceu, naquele momento, foram as forças conservadoras mobilizadas no interesse de barrar o alcance da discussão sobre discriminação por orientação sexual até o espaço público. Como nota Lígia SANTOS (2012, p. 39), ironicamente "não foram os espectadores do ambiente escolar - a quem o material se destinava - que rejeitaram o vídeo, mas sim agentes do poder público, diante da reação de vozes conservadoras que conseguiram se fazer ouvir na mídia e no poder Legislativo".

No dia que antecedeu o veto (24 de maio de 2011) foi convocada uma reunião com o Secretário-Geral da Presidência da República, Gilberto de Carvalho, pela Frente Parlamentar Evangélica com apoio e participação da Frente Parlamentar Católica. O assunto em pauta seria o kit de cartilhas e vídeos que o MEC planejava distribuir nas escolas. ${ }^{63}$ Através de pressões e chantagens envolvendo ameaças à estabilidade política do então ministro-chefe da Casa Civil, Antonio Palocci, as Frentes evangélica e católica exigiram a suspensão do kit por parte do Ministro da Educação Fernando Haddad (SANTOS, 2012, p. 57). Impossível deixar de notar a expressiva capacidade de articulação e de imposição de posições das bancadas religiosas no Congresso brasileiro, ${ }^{64}$ o que nos interpela pela necessidade de discutir a fundo se efetivamente temos conseguido consolidar um Estado verdadeiramente laico, quando atestamos que políticas públicas de notável urgência social ${ }^{65}$ são simplesmente descartadas por motivos confessionais. ${ }_{63}$ Conferir notícia sobre a convocação da reunião no sítio virtual da Câmara dos Deputados:
http://www2.camara.leg.br/camaranoticias/noticias/EDUCACAO-E-CULTURA/197521-DEPUTADO-QUER-
CONVOCAR-PALOCCI-PARA-PRESSIONAR-GOVERNO-CONTRA-KIT-ANTI-HOMOFOBIA.html.
Acessado em 23/10/2015.

${ }^{64}$ A Frente Parlamentar Evangélica contava com 131 representantes na época (SANTOS, 2012, p. 58). De acordo com reportagem veiculada pela Revista $O$ Viés em 12 de dezembro de 2011, a bancada evangélica cresceu, nas eleições nacionais de 2010, de 46 deputados (9\% do total da Casa) para 68 deputados (13,2\% do total), um crescimento de mais de 50\%. Contava, naquele momento, com 3 representantes no Senado. Disponível em: http://www.revistaovies.com/reportagens/2011/12/um-estado-laico-com-bancada-evangelica/. Acessado em 23/10/2015. Deste modo, "a bancada evangélica tem uma força enorme no alcance de votações, pois, ao ser comparada com outros partidos, seria a terceira maior do Congresso, perdendo apenas para o PT e o PMDB" (SANTOS, 2012, p. 59).

${ }^{65}$ A oficial de educação preventiva da UNESCO no Brasil, Rebeca Ontero, diz esperar que o governo brasileiro sigas as recomendações da ONU de desenvolver políticas públicas de combate à homofobia nas escolas, haja vista a persistência e a gravidade desse problema no país: "É dever do Ministério da Educação, e também de outros órgãos do governo, providenciar estratégias para a redução do bullying homofóbico nas escolas. $\mathrm{O}$ professor, há anos, demonstra que não está preparado para lidar com a questão da diversidade sexual, e os materiais pedagógicos têm um importante papel para mudar esse quadro. (...) O kit que nós avaliamos do programa Escola sem Homofobia é muito bom porque trabalha a questão de forma adequada, com respeito. $\mathrm{O}$ mais interessante no material é que envolvia a formação de professores, que hoje infelizmente ainda não sabem lidar com a homofobia". Disponível em: http://noticias.terra.com.br/educacao/unesco-e-dever-do-mec-criarpolitica-contra-homofobia-na-escola,214a42ba7d2da310VgnCLD200000bbcceb0aRCRD.html. Fonte: Terra 
Interessa-nos compreender a configuração desse jogo de alianças, desse arranjo de forças que levou a semelhante recuo por parte da Presidência da República. Afinal, quais eram os sujeitos interessados no boicote desse Projeto? Em nome de quem, e sob qual pretexto, agiram? Quais ideais os inspiraram? Mais importante é visualizar esse processo a partir dos discursos veiculados pela opinião pública representada na mídia e pelas parlamentares opositoras do PESH, buscando selecionar quais desses discursos contêm argumentos que realmente pesaram na decisão presidencial e que eventualmente possam trazer alguma contribuição para um debate controvertido no domínio dos conceitos aqui já debatidos, ou no domínio de questões presentes na teoria política e na teoria constitucional, que serão articuladas mais adiante.

\subsection{Repercussão das políticas na esfera pública: argumentos de defesa e de ataque}

Antes de tudo, gostaríamos de registrar que os discursos não exprimem apenas consensos ou negociações, mas são meios responsáveis por canalizar o poder, de modo que uma teoria do discurso não pode prescindir de uma teoria do poder subjacente. Ao exprimir poder, o discurso torna evidentes diferentes posições discursivas assimétricas, nas quais estão situados sujeitos com maiores ou menores condições de terem seu ponto de vista, seus interesses e valores observados. A produção do discurso se prolifera e se reproduz na sociedade através de controle, seleção, organização e redistribuição, de acordo com um sistema de significação de valores, crenças e saberes. Mais do que isso, o discurso não é apenas meio de exercício do poder como também sua condição de autorreprodução.

E os discursos dependem de canais através dos quais são conduzidos desde seu emissor até seu receptor. Obviamente, o processo de produção e reprodução de discursos não é equânime tendo em vista o potencial de alcance desses canais. Muitos fóruns discursivos permanecem com seus produtos confinados aos seus próprios limites, ao conhecimento de seu próprio público, enquanto alguns fóruns têm sobre si uma atenção geral proporcionada pela atuação dos meios de comunicação de massa, de modo que as mensagens lá emitidas tornamse de conhecimento amplo e ultrapassam o contexto local, com o auxílio da televisão, do rádio, da mídia impressa e da internet. Esses veículos de comunicação em massa não são neutros, antes são integrantes de projetos mais amplos de poder, voltados a atender 
determinados públicos e seus respectivos interesses em moldar a opinião pública ${ }^{66}$ em um ou outro sentido. Muito embora revestida de aparente homogeneidade, $a$ opinião pública apresentada como um substantivo no singular, como se fosse uma opinião uniforme - reflete um complexo de lutas por posições sociais relevantes, por visibilidade, por conquista de estima social e política. É mais fácil vislumbrarmos dissensos do que consensos em suas cercanias. Com efeito, a mídia seleciona quais discursos serão apresentados, antecedidos de interpretações enviesadas conforme os interesses daqueles que a movimentam. Através dessa manipulação, a mídia cria opiniões e preferências, daí falar-se em dispositivo pedagógico da mídia, um artefato capaz de ensinar modos de vida e de ser e estar no mundo e, finalmente, de produzir subjetividades (SANTOS, 2012, p. 24).

Antes mesmo de ter sido lançado, o material do PESH já era fonte de discussões acaloradas, ${ }^{67}$ como registra artigo jornalístico intitulado "MEC prepara kit anti-homofobia e provoca reação", datado de 20 de dezembro de 2010. ${ }^{68}$ O artigo comenta sobre como o tema tem divido as opiniões na internet entre defensores e detratores do material do MEC. Dentre os detratores, sublinha a atuação midiática do deputado federal ultraconservador Jair Bolsonaro (PP/RJ $)^{69}$ para barrar o Projeto sob a justificativa de que o material era perigoso

\footnotetext{
${ }^{66}$ As opiniões enfeixadas no espaço público tornam-se opinião pública quando gozam de um amplo assentimento, resultante de uma controvérsia na qual propostas, informações e argumentos podem ser elaborados de modo mais ou menos racional. Ver HABERMAS, 2003b, p.94. Não se pode olvidar que essas controvérsias estão sujeitas a todo tipo de manipulação midiática, de tal sorte que a opinião pública é mais adequadamente vista como resultado de um confronto.

${ }^{67}$ Seria impossível catalogar e reproduzir todos os discursos proferidos em virtude da polêmica em torno do PESH. Em tempos de recrudescimento dos canais de comunicação e informação, poderíamos encontrar tais discursos dispersos por várias mídias, como as revistas e os jornais impressos, os noticiários televisionados, os jornais, sites, blogs e vídeos da internet. Assistimos também a uma espécie de democratização do pronunciamento, através da qual praticamente toda pessoa tem oportunidade de publicar sua fala na internet, facilitada por meio das redes sociais - democratização que não garante, contudo, a contrapartida de que uma opinião repercutirá e será levada a sério no debate público; a posição de quem fala ainda é um meio de influência política. Vistas as limitações de qualquer empreendimento de seleção de discursos - e esse empreendimento necessariamente será seletivo -, cabe-nos compilar as falas que julgarmos importantes para nosso presente propósito, qual seja, o de esboçar ideias divulgadas a respeito do PESH que têm alguma relevância em termos de elementos para um debate acadêmico em teoria social, teoria política e teoria constitucional.

$68 \quad$ Disponível em: $\quad$ http://terramagazine.terra.com.br/interna/0,,OI4851100-EI6594,00MEC+prepara+kit+antihomofobia+e+provoca+reacao.html. Acessado em: 26/10/2015.

${ }^{69}$ A primeira vez em que Bolsonaro se manifestou publicamente foi durante o Programa de televisão "Manhã Maior", da Rede TV, em 25 de novembro de 2010, ocasião na qual se discutia a chamada "Lei da Palmada", mesma ocasião em que o deputado defendeu o uso da palmada para corrigir filhos com "tendências homossexuais". No mesmo programa estava o integrante da ABGLT Beto Jesus, que defendeu que "orientação sexual é um direito!”. Depois disso, provavelmente no início de 2011, em participação em programa da TV Câmara, o deputado se manifestou novamente sobre o kit, dizendo que "a grande verdade, o que eles estão discutindo aqui e sabem disso, não querem falar, não querem tocar no assunto, é que este ano o governo federal irá distribuir um 'kit gay' para a garotada do primeiro grau, a pretexto de combater a homofobia e que, na verdade, está estimulado o homossexualismo, com filmetes para a garotada do primeiro grau, de 6,7 e 8,9 e 10 anos. É isso o que eu descobri sem querer e tamo [sic] tomando providência para impedir a distribuição deste kit gay nas escolas" (SANTOS, 2012, pp. 53-54).
} 
"por incentivar a homossexualidade entre os estudantes" - referindo-se principalmente aos vídeos que haviam sido exibidos preliminarmente na Comissão de Direitos Humanos da Câmara dos Deputados. A popularização do termo pejorativo kit gay ${ }^{70}$ é vinculada a Bolsonaro. Na mesma reportagem, há posicionamentos favoráveis ao kit, por Rosilea Wille, coordenadora geral de Direitos Humanos do MEC e vinculada à SECAD, por Toni Reis, presidente da ABGLT, e por Clara Goldman, vice-presidente do Conselho Federal de Psicologia (CFP), os quais não repercutiram com a mesma amplitude pública. É válido transcrever trechos das declarações dadas por cada uma delas, defendendo a pertinência do material e denunciando a distorção proposital criada por Bolsonaro e suas seguidoras:

Foi colocado que vamos passar informações sobre diversidade sexual e identidade de gênero para crianças de sete anos. Isso nunca foi a decisão do Ministério. $O$ projeto está sendo pensado para o Ensino Médio. Não é um projeto que vai cair de paraquedas nas escolas. Vai ser vinculado à formação dos professores. Há todo um anteparo, uma sustentação pedagógica (Rosilea Wille, coordenadora geral de Direitos Humanos do MEC).

(...)

O que está sendo dito é totalmente distorcido. Não queremos incentivar a homossexualidade. Ela não precisa de incentivo algum. Queremos incentivar o respeito à cidadania, à não violência, à dignidade humana. Quem está falando isso são pessoas homofóbicas, fundamentalistas religiosos. Estes são os grandes incentivadores da violência e do desrespeito. (...) Os vídeos são extremamente didáticos. Explicam a questão do travesti, do bissexual, da lésbica. São muito bacanas porque vão ajudar o adolescente a entender a situação. Muitas vezes, o preconceito vem da desinformação. Estamos super tranquilos com esse trabalho. Ele não vai ser censurado por pessoas homofóbicas (Toni Reis, presidente da ABGLT).

(...)

$\mathrm{O}$ argumento esconde um princípio de que essa sexualidade é ruim e tem que ser combatida, evitada. Essa é a base do pensamento homofóbico. O kit não orienta, não estimula, mas problematiza. Coloca no seu devido lugar a discussão que deve ser feita. O objetivo é que as pessoas LGBT possam ser respeitadas e que caibam na nossa sociedade, nos nossos espaços coletivos, o respeito a essa diversidade (Clara Goldman, vice-presidente do CFP).

Em retaliação e com objetivo de empreender uma contracampanha ideológica para atingir o PESH, o deputado Jair Bolsonaro mandou distribuir em escolas e residências do estado do Rio de Janeiro 50 mil cópias de um plano em que denunciava aquilo que intitulava

\footnotetext{
${ }^{70}$ Como observa Lígia SANTOS (2012, p. 55), o jogo de nomenclaturas ("uma disputa em torno da 'verdade' do kit") é propositalmente aproveitado pelos inimigos do PESH para uma apresentação negativa distorcida dos materiais à sociedade, gozando da vantagem de que esse tipo de discurso polêmico é facilmente disseminado. "A nomenclatura erroneamente difundida em torno do kit como 'kit gay' dá uma conotação totalmente diferente à que intencionalmente tem. Ao ser analisado, o termo 'kit gay' faz referência a um material homossexual, em primeira instância, afinal, gay se refere à [sic] práticas e/ou valores homoafetivos. Logo, ter um kit educacional com esta nomenclatura remete à ideia de algo que "ensinaria a homossexualidade".
} 
"Plano Nacional da Vergonha",71 acompanhado com a advertência de que "querem transformar seu filho de 6 a 8 anos em homossexual”, de que o Plano de Promoção da Cidadania LGBT almejava convencer os estudantes de que "ser gay ou lésbica é motivo de orgulho para a família brasileira". ${ }^{72}$ No panfleto, o deputado contrapõe comentários enviesados às diretrizes do PESH, favorecendo uma interpretação deturpada negativa de seu texto e insinuando o caráter periculoso e indevidamente subversivo e corrupto do Projeto. Compila ainda frases de lideranças e ativistas LGBT descontextualizadas e deslocadas, de modo a conferir uma aparência enganosa a essas declarações, nas quais há a associação de homossexualidade e pedofilia, de homossexualidade e promiscuidade, a insinuação de que o movimento LGBT pretende destruir "a família” etc. Como observa Lígia SANTOS (2012, p. 57), "quanto mais é discursado sobre isso desta maneira mais é veiculado em mídias, mais visibilidade essa ideia tem e, consequentemente, crédito e poder”.

Os argumentos seculares de rejeição do PESH provenientes da opinião pública centraram-se em dois eixos principais: $a$ ) o kit induziria as estudantes à prática e assimilação do homossexualismo e $b$ ) não caberia ao Estado, através de intervenções educacionais, adentrar em um âmbito privado de formação de identidades sexuais, o qual deveria pertencer ao domínio exclusivo da família. Em um país de maioria da população cristã, não é surpreendente que parte considerável dos argumentos tenha embasamento em doutrinas religiosas.

$\mathrm{O}$ primeiro grupo de argumentos seculares, o qual chamaremos de argumento da identidade dinâmica, assume a premissa de que a exposição de adolescentes ao material incentivá-los-ia a incorporar uma identidade homossexual, ou não heterossexual em sentido amplo, sendo esta identidade já previamente valorada como negativa, ruim, perniciosa, portanto a urgência de evitá-la e combatê-la. Esse argumento tem sido propagado veementemente pelo deputado Jair Bolsonaro e demais políticos conservadores, ${ }^{73} \mathrm{e}$ frequentemente é repetido por centenas de pessoas em comentários de notícias veiculadas pela

\footnotetext{
71 Disponível para download em: www.bolsonaro.com.br/kit.../Informativo-KitGay.pdf. Acessado em 26/10/2015.

72 Disponível em: http://www1.folha.uol.com.br/fsp/cotidian/ff1105201118.htm. Folha de São Paulo, 11 de maio de 2011, por Rodrigo Rötzsch. Acessado em: 26/10/2015.

${ }^{73}$ Nesse sentido, conferir fala do deputado Magno Malta, na Assembleia Legislativa do Mato Grosso, em que sugere que o ministro Fernando Haddad pretende transformar as escolas em "academias preparatórias de homossexualidade". Disponível

em: http://ultimosegundo.ig.com.br/educacao/veja+videos+do+kit+antihomofobia+do+mec/n1596964952707.html. Fonte: "Veja os vídeos do kit anti-homofobia do MEC". Home IG, Último Segundo, por Naiara Leão, 19/05/2011. Acessado em 28/10/2015.
} 
internet. Encontramos até mesmo um abaixo-assinado virtual, ${ }^{74}$ assinado por 37.952 pessoas, que conclamava os cidadãos brasileiros a se manifestarem contra aquele que seria "o maior escândalo deste país, o kit gay", material que faria "apologia à homossexualidade" nas escolas. Vejamos a seguinte declaração de Bolsonaro:

\begin{abstract}
Eles estão pregando na escola o combate à homofobia, já estão fazendo a partir da molecada com 6 anos de idade. Um dos itens ali: distribuição de livros às bibliotecas com a temática diversidade sexual para o público infantil. Ou seja, livros com gravuras de homens se beijando, né, ou em posições homoafetivas, para a molecada a partir dos 6 anos de idade, vai tá estimulando a molecada! A partir do momento que o moleque vê que tem dois meninos, dois homens, se abraçando, mantendo essa relação amorosa, ele passa a ser uma presa fácil para pedófilos. Se um homem quiser abraçar o moleque, ele vai achar que aquilo é normal (Jair Bolsonaro, deputado federal)..$^{75}$
\end{abstract}

Com facilidade, podemos notar já à primeira vista a nítida irracionalidade desse discurso, o qual não se ampara em nenhuma pesquisa científica ou teoria acadêmica plausível, não passando de mero preconceito repousado no senso comum. A própria escolha dos vocábulos empregados evidencia enorme desconhecimento acerca do tema. Nem por isso essa opinião tem deixado de ser corroborada em falas cotidianas a respeito das iniciativas de combater a homofobia nas escolas. Mais adiante enfrentaremos, com apoio em teorias sociológicas e antropológicas sobre formação de identidades, o argumento da identidade dinâmica, mesmo que o esforço para refutar um argumento tão falaciosamente absurdo possa parecer demasiadamente dispendioso.

O segundo grupo de argumentos seculares, o qual chamaremos de argumento da privacidade familiar, é mais sério e rebuscado do ponto de vista de uma teoria moral, jurídica e política, posto que é um dos alicerces da divulgada concepção liberal de democracia e, logo, encontra no mínimo amparo teorético. Esse argumento consiste em negar a adequação de uma "política de sexualidade" nas escolas sob a justificativa de que a sexualidade é uma questão de foro privado e só merece ser discutida pelas famílias, e não pelos sujeitos escolares em fóruns

\footnotetext{
${ }^{74}$ Trata-se de petição pública intitulada "Somos contra o maior escândalo deste país, o Kit Gay", direcionada à Presidente da República, ao Congresso Nacional, ao Supremo Tribunal Federal e às Assembleias Legislativas. Em sua exposição de motivos, é dito que o material do MEC incentivaria crianças de 7 a 10 anos ao "homossexualismo". Disponível em: http://www.peticaopublica.com.br/pview.aspx?pi=PROL. Acessado em 28/10/2015.

75 Disponível em: http://notcias.terra.com.br/educacao/dois-anos-apos-veto-mec-diz-que-ainda-analisa-kit-antihomofobia,62a3a67b302be310VgnVCM10000098cceb0aRCRD.html. Fonte: "Dois anos após veto, MEC diz que ainda 'analisa' kit anti-homofobia”, por Angela Chagas, em 17/05/2013, Notícias Terra. Acessado em $28 / 10 / 2015$.
} 
públicos. Em entrevista ao Portal Terra, ${ }^{76}$ o então deputado João Campos (PSDB/GO) diz que “essa questão de orientação sexual é algo que diz respeito à vida privada, não à escola. Quem faz a opção, a gente respeita, mas agora o poder público financiar um programa que vai estimular os adolescentes a serem homossexuais é errado". Um dos chamados formadores de opinião que mais enfaticamente se manifestaram foi o colunista da Revista Veja Reinaldo Azevedo, ${ }^{77}$ que chegou a empregar o argumento da privacidade:

\begin{abstract}
Ora, quem deu a Haddad o direito de se imiscuir, assim, na organização das famílias? Com que preparo especial e com que competência específica professores exibiriam esses filmes nas milhares de escolas brasileiras? (...) É uma vigarice intelectual e moral associar os críticos às barbaridades contidas naqueles vídeos à homofobia. $O$ que a sociedade não aceita é que o estado se meta dessa forma na organização das famílias. Mais: há uma diferença nada ligeira entre combater o preconceito à homossexualidade e a linguagem que beira a apologia (Reinaldo Azevedo, colunista da Revista Veja; grifamos) ${ }^{78}$
\end{abstract}

O mesmo argumento foi endossado pela presidente da república, Dilma Rousseff, enquanto razão para vetar o PESH:

Não podemos interferir na vida privada das pessoas. Não haverá autorização para esse tipo de política de defesa de A, B, C ou D. Agora o governo pode sim fazer uma educação de que é necessário respeitar a diferença e que você não pode exercer práticas violentas contra aqueles que são diferentes de você (Presidente Dilma Rousseff; grifamos). ${ }^{79}$

Em ambas as falas, aparece a ideia de que políticas escolares que abordem a homofobia como problema são uma intromissão indevida do Estado na vida privada das pessoas (ou das famílias - o que não é exatamente a mesma coisa, como veremos mais à frente). Interessante notar que em ambas o recurso retórico à privacidade serviu para justificar a negação de uma política pública de direitos que beneficia o segmento LGBT, ou seja, o argumento da privacidade foi lançado claramente com o intuito de negar direitos a sujeitos fragilizados.

${ }^{76}$ Disponível em: http://blog.comshalom.org/carmadelio/34507-polemico-kit-gay-vetado-pela-presidencia-em2011-continua-vivo. Fonte: "Polêmico 'Kit Gay' - vetado pela presidência em 2011 - ainda continua 'vivo'!", em Blog Carmadélio, em 20/05/2013. Acessado em 28/10/2015.

${ }^{77}$ Em busca no sítio virtual da Revista Veja (www.veja.abril.com.br), na seção "Colunistas", foram encontradas 177 colunas assinadas por Reinaldo Azevedo com a palavra-chave "kit gay", número hiperbólico que mostra a obsessão do colunista com o assunto.

78 Disponível em http://veja.abril.com.br/blog/reinaldo/geral/haddad-tenta-se-livrar-da-propria-obra-e-volta-aassociar-a-oposicao-ao-kit-gay-a-homofoibia-uma-ova-continua-a-ofender-as-pessoas-de-bom-sensol, escrita em 15/02/2012. Acessado em 28/10/2015.

79 Disponível em: http://veja.abril.com.br/noticia/brasil/dilma-diz-que-discorda-do-kit-gay, escrita em 26/05/2011.Acessado em 28/10/2015. 
O ano de 2015 previa a discussão e elaboração, até junho, dos Planos Municipais e Estaduais de Educação que definiam metas e estratégias para o próximo decênio. Antes disso, no ano de 2013 houve a já referida votação do Plano Nacional de Educação no Congresso Nacional. Nessas ocasiões, todo o debate anteriormente esboçado voltou à tona. Reapareceram os argumentos seculares e confessionais, bem como uma terminologia bastante disseminada para aglutinar os aspectos do tema e dar-lhe uma feição negativa: "ideologia de gênero". Este argumento alega que as políticas públicas de promoção da igualdade das sexualidades oprimidas têm trazido um caráter ideológico para as discussões sobre sexo e sexualidade ao pressupor que cada indivíduo teria o direito de escolher seu próprio gênero, quando estes temas deveriam ser entendidos do ponto de vista biológico da imbricação entre homem/macho e mulher/fêmea. Mais uma vez, católicos e evangélicos, inclusive representados institucionalmente, foram os principais responsáveis pela "cruzada" contra as palavras gênero e sexualidade na educação. ${ }^{80}$

Manifestaram-se contrariamente à "ideologia de gênero" pelo menos quatro religiosos. ${ }^{81} \mathrm{O}$ cardeal Dom Odilo Scherer invocou o argumento da privacidade: "Os legisladores [devem evitar] a ingerência do Estado no direito e dever dos pais e das famílias de escolherem o tipo de educação dos filhos" (grifamos). ${ }^{82}$ Em nota divulgada em nome da Confederação Nacional dos Bispos do Brasil (CNBB) em 10 de junho de 2015, Dom Fernando Rifan articula um complexo de argumentos que inclui o argumento da identidade dinâmica, a defesa "da família", argumentos declaradamente religiosos e até mesmo pseudocientíficos :

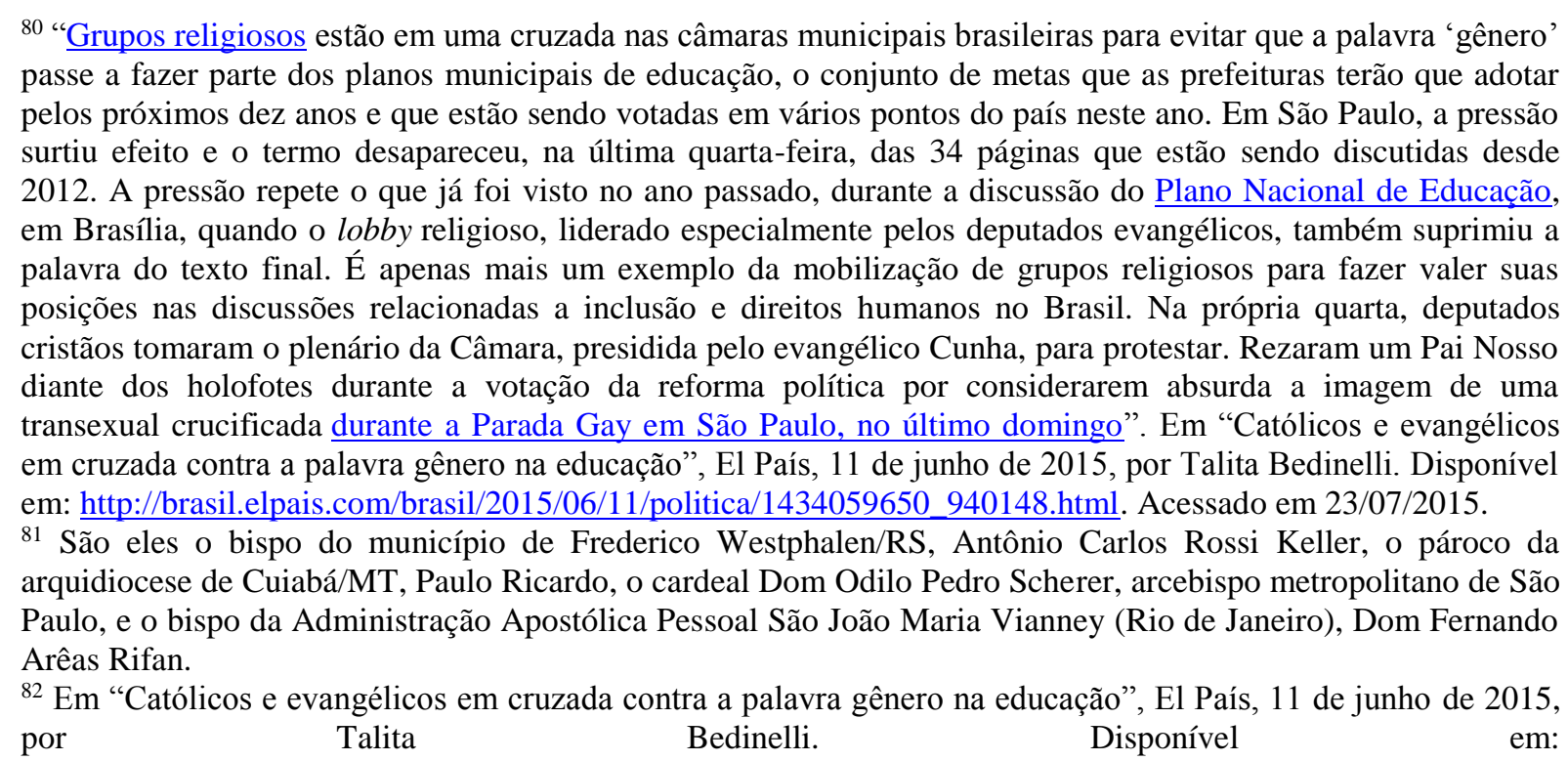
http://brasil.elpais.com/brasil/2015/06/11/politica/1434059650_940148.html. Acessado em 23/07/2015. 


\begin{abstract}
As expressões "gênero" ou "orientação sexual" referem-se a uma ideologia que procura encobrir o fato de que os seres humanos se dividem em dois sexos. Segundo essa corrente ideológica, as diferenças entre homem e mulher, além das evidentes implicações anatômicas, não correspondem a uma natureza fixa, mas são resultado de uma construção social. Seguem o célebre aforismo de Simone de Beauvoir: "Não se nasce mulher, fazem-na mulher". Assim, sob o vocábulo "gênero", é apresentada uma nova filosofia da sexualidade. Negar a biologia e a psicologia é negar a ciência! A escola deve ter compromisso com a verdade, fomentando o conhecimento da realidade e não doutrinando os alunos com ideologias. O papel da educação deve ser o de fomentar o conhecimento da realidade, não a sua desconstrução, ou a neutralização das características psicológicas e biológicas dos meninos e das meninas. Devemos ensinar os nossos filhos e alunos a respeitar as pessoas, independentemente do sexo, raça, condição social, etc., mas isso não quer dizer confundi-los com uma ideologia como essa. Na verdade, os que adotam o termo gênero não estão querendo combater a discriminação, mas sim "desconstruir" a família, o matrimônio e a maternidade e, deste modo, fomentam um "estilo de vida" que incentiva todas as formas de experimentação sexual desde a mais tenra idade. Além desses dados da ciência e da lei natural, a doutrina católica nos ensina sobre o nosso dever em relação à própria identidade sexual: "Deus criou o ser humano, homem e mulher, com igual dignidade pessoal e inscreveu nele a vocação do amor e da comunhão. Cabe a cada um aceitar a própria identidade sexual, reconhecendo sua importância para a pessoa toda, a especificidade e a complementaridade" (Compêndio do CIC, 487) ${ }^{83}$ (grifamos).
\end{abstract}

A posição expressa pela CNBB reitera a tendência de grande parte das instituições religiosas a manter o oligopólio do disciplinamento do comportamento dos indivíduos, mesmo daqueles que não professam sua doutrina, à revelia da laicidade estatal. Também reitera a tendência conservadora, reticente diante das mudanças comportamentais e do abalo das estruturas de poder e hierarquias tradicionalmente fixas, através da insistência em manter intocados institutos sociais como "família", "matrimônio" e "maternidade". Também revela a imposição dos supostos "desígnios de Deus” (“a doutrina católica nos ensina, sobre o nosso dever em relação à própria identidade sexual...") no debate público que ocorre necessariamente em uma esfera pública plural e não uniformemente católica. Além de tudo, é sintomática da patente inconsistência do argumento de Dom Fernando Rifan a canhestra associação entre ciência - em uma concepção bem estrita - e religião. Afinal de contas, desde quando, e com que propósito, a Igreja passou a defender um diálogo harmônico com as ciências da natureza? Desde quando a doutrina cristã tem adotado um compromisso tão rígido com os pressupostos científicos?

83 Disponível em: http://www.cnbb.org.br/outros/dom-fernando-areas-rifan/16673-a-ideologia-de-genero. Acessado em 28/10/2015. "A ideologia de gênero", em sítio virtual da CNBB, 10 de junho de 2015. 
Como é de praxe e ínsito a toda manifestação pública, houve contramanifestações de repúdio às atitudes dos religiosos e conservadores: LGBT, intelectuais, ${ }^{84}$ políticas e demais defensoras das políticas públicas manifestaram-se em todo o país pela sua urgência. Resultado disso pode ser visto no texto do "Manifesto pela igualdade de gênero na educação: por uma escola democrática, inclusiva e sem censuras", ${ }^{85}$ assinado por cerca de 100 entidades (entre associações de militância, coletivos, núcleos de pesquisa e grupos de estudo acadêmicos, comissões governamentais etc.), o qual coloca a questão da igualdade de gênero como uma obrigação constitucional derivada da compreensão de direitos humanos.

Devemos fazer justiça e reconhecer que a posição sobre gênero e sexualidade e suas relações com a violência homofóbica não é homogênea, mas matizada dentro das próprias instituições religiosas. Há correntes de autoridades religiosas que se manifestaram pela necessidade de políticas públicas de combate à homofobia no campo educacional. Exemplar é a instigante fala da pastora Romi Bencke, ${ }^{86}$ secretária-geral do Conselho Nacional de Igrejas Cristãs do Brasil:

A abordagem das questões relacionadas a gênero é essencial. É importante que
educadores e educadoras sejam preparadas para abordar esses temas de forma
madura e inclusiva. O Brasil é um país em que a violência está inserida no cotidiano
e um número significativo de casos tem motivação sexista. Esse é o caso da
violência contra mulheres e contra a população LGBTT. É lamentável e, ao mesmo
tempo, assustador, que a violência contra mulheres não gere indignação. São casos e
mais casos todos os dias e fica por isso mesmo. É necessária uma mudança cultural e
a educação tem um papel estratégico nisso. A mudança de cultura é gradativa, mas
precisamos começar a falar abertamente sobre estes temas para substituirmos uma
concepção de mundo patriarcal por uma visão de mundo diversificada. Essa
conversa é necessária em todos os espaços, especialmente nas escolas. Em nosso
país prevalecem valores tradicionais que tendem a reforçar relações de poder

${ }^{84} \mathrm{Em}$ setembro de 2015 a filósofa estadunidense Judith Butler veio ao Brasil proferir palestras no Seminário Queer, em São Paulo. Sua vinda causou tumulto: reconhecida como grande nome da teoria queer e da questão do gênero, havia um frenesi de fãs lotando o SESC Vila Mariana, bem como vários manifestantes do lado de fora do recinto segurando cartazes e entoando palavras contrárias à "ideologia de gênero". Isso porque a visita da filósofa ocorreu pouco tempo após o recuo da Secretaria Municipal de São Paulo quanto ao compromisso com as políticas públicas de gênero e sexualidade nas escolas. Na oportunidade, Butler comenta o episódio, alertando para a capacidade de os movimentos organizadores, através de sua incansável luta, reverter a situação. Conferir: http://g1.globo.com/educacao/noticia/2015/09/nao-e-o-fim-da-historia-diz-filosofa-sobre-ensino-de-genero-nasescolas.html. Acessado em 14/09/2015. Em "'Não é o fim da história', diz filósofa sobre ensino de gênero nas escolas", Portal de Notícias G1, 10/09/2015, por Ana Carolina Moreno.

${ }^{85}$ Disponível em: www.portal.abant.org.br. Acessado em 28/10/2015. Ver comentário sobre o manifesto em Carta Capital, "Gênero e diversidade sexual nas escolas: uma questão de direitos humanos", por Vanessa Alves Vieira, Bernardo Fonseca Machado, Michele Escoura Bueno e Ana Paula Meirelles Lewin publicado 17/07/2015, disponível em: http://www.cartacapital.com.br/sociedade/genero-e-diversidade-sexualnas-escolas-uma-questao-de-direitos-humanos-6727.html. Acessado em 23/07/2015.

86 "Abordagem de questões de gênero nas escolas é essencial, diz pastora". Gabriel Maia Salgado. Em Brasil de Fato. São $\quad$ Paulo - 16/06/2015. Disponível em: http://operamundi.uol.com.br/conteudo/samuel/40717/abordagem+de+questoes+de+genero+nas+escolas+e+esse ncial+diz+pastora.shtml. Acessado em: 23/07/2015. 
desiguais e opressivas. Problematizar tais valores é também uma tarefa da educação (grifamos).

A fala da pastora também traz uma inspiradora reflexão sobre os plurais modelos de família e sobre o papel das religiões no mundo contemporâneo:

\begin{abstract}
Os modelos de família de hoje são diferentes dos modelos de família do início do século 20, por exemplo. Não podemos mais dizer o que é um modelo de família aceitável ou não aceitável. Se em uma determinada família há amor, respeito, carinho e diálogo, pode-se dizer que ali existe uma família, independentemente se forem dois homens, duas mulheres, uma mulher ou um homem. Agora, se em uma família tivermos desrespeito, agressões, dominação de poder, etc, pode-se dizer que ali temos uma família com problemas, independentemente de quem a compõe. É isso que a religião deveria avaliar e contribuir positivamente para transformar: as relações humanas. Contribuir positivamente para uma cultura de paz. Nos grupos que atuam fortemente contra os temas de gênero percebo que há uma resistência em aceitar as transformações que ocorreram na sociedade e, em muitas delas, de maneira rápida. As mudanças desestabilizam. Para reencontrar a segurança, para manter o mundo organizado, é necessário apegar-se às concepções que causam sensação de segurança. Outra compreensão é a de que há uma dificuldade em aceitar que nos tempos de hoje não cabe mais à religião normatizar a vida das pessoas. Lidar com as autonomias é difícil, mas as religiões precisam aceitar isso. A liberdade humana é um valor que também se relaciona com a fé (grifamos).
\end{abstract}

Em seu discurso, a pastora faz referências à concepção aqui defendida de educação emancipatória: uma educação responsável por desestabilizar relações de poder e comprometida com o aumento da autonomia, da liberdade e da igualdade dos sujeitos. Também reconhece o problema do sexismo e do heterossexismo e o papel central das escolas na mudança gradual de uma cultura discriminatória. Ao abordar a questão da família, Romi Bencke admite a pluralidade dos arranjos familiares contemporâneos e a tríade amor/afeto/respeito como núcleo conceitual do ambiente familiar, para além dos arranjos tradicionais baseados na heteroconjugalidade, cada vez mais escassos hoje em dia. Sua opinião sobre o papel das religiões em uma cultura democrática também é bastante sóbria (“contribuir positivamente para uma cultura de paz...”) e afinada com os princípios pósmetafísicos e pós-convencionais do Estado democrático de direito ("não cabe mais à religião normatizar a vida das pessoas..."). Transcrevemos aqui a entrevista com a religiosa para mostrar que é possível uma harmonia entre doutrinas religiosas, fé cristã, Estado democrático de direito e respeito à autonomia e à individualidade de todos os seres humanos em sua diversidade e diferença. 
No nível da análise política, ao buscarmos entender os processos pelos quais as políticas públicas de combate à homofobia nas escolas têm sido obstruídas, nos deparamos com um típico conflito que marca o modelo societário pluralista contemporâneo: o conflito entre maiorias e minorias. De um lado, grupos políticos instrumentalizam doutrinas religiosas e proposições conservadoras com o afã de barrar conquistas de direitos das sexualidades oprimidas e, para isso, se utilizam de argumentos tais como a privacidade familiar e a anormalidade das identidades não heterossexuais. De outro, grupos de pessoas comprometidas com a cidadania LGBT invocam direitos constitucionais (liberdade, igualdade, reconhecimento da cidadania, acesso à educação, proteção contra a violência) para defender a adequação jurídica de políticas públicas que combatam a homofobia nas escolas, uma vez que essa forma de discriminação funciona como um fator de diminuição de direitos. Os argumentos de defesa dessas políticas públicas centram-se em argumentos constitucionais sobre o caráter igualitário do Estado democrático de direito. No processo político, triunfa aquele grupo capaz de exercer o poder de fazer valer seus interesses e suas convicções. Mas, em uma democracia constitucional, as minorias estão protegidas das decisões políticas de uma maioria tirânica que venham a eliminar as condições de legítima existência das formas de vida minoritárias. Para esse propósito servem os direitos: na linguagem de Ronald Dworkin, direitos são trunfos que protegem os indivíduos da volátil vontade majoritária.

Mesmo que a maioria da população brasileira se negue a reconhecer a dignidade de lésbicas, gays, bissexuais, travestis, transexuais e transgêneros, estas possuem certas garantias conferidas pelo sistema constitucional, que podem ser reivindicadas ainda que as leis promulgadas nos espaços políticos ordinários busquem torná-las inócuas. Desde que haja homofobia nas escolas, milhares de crianças e adolescentes que se afastam da matriz heteronormativa compulsória têm seus direitos fundamentais gravemente violados. Por esse motivo, muitas delas ficam à parte do sistema educacional ou abaixo de um adequado rendimento escolar. Se o direito à educação se estende a todas as cidadãs e a todos os cidadãos, e se um ordenamento constitucional legítimo deve se orientar pelo princípio de que todas e todos devem ser tratadas com igual consideração e respeito, o fato de haver pessoas que sofrem violências nas escolas em virtude de sua identidade sexual é uma afronta ao complexo de direitos constitucionais garantidos aos indivíduos. Seguindo esse raciocínio, cabe-nos perquirir a relação que as políticas públicas de combate à homofobia nas escolas guardam com a Constituição. Afinal, as sexualidades oprimidas teriam direito de exigir do Estado políticas públicas voltadas à garantia de um ambiente escolar não violento e de uma 
educação não discriminatória? De outro lado, os grupos conservadores interessados em evitar essas políticas teriam direito de exigir do Estado sua contenção e a garantia de uma educação que não problematize questões de gênero e de sexualidade e, assim, favoreça a manutenção dos arranjos familiares tradicionais?

Neste ponto da discussão, o debate deixa o campo meramente político do enfrentamento entre interesses e vontades conflitantes, e passa ao campo jurídico dos direitos: existe um fundamento constitucional para mobilizar esforços no sentido de erradicar a homofobia? DWORKIN (1985, pp.2-3) observa que as políticas públicas que regem o destino de uma comunidade podem ser fundamentadas em argumentos de política e em argumentos de princípio. Aqueles são baseados em objetivos coletivos e buscam mostrar que a comunidade se beneficiará, como um todo, caso um determinado programa seja seguido; estes são baseados em direitos e defendem que um programa deve ser levado em frente ou abandonado devido aos seus impactos em determinadas pessoas, mesmo que a comunidade tenha algum prejuízo em consequência. Caso as políticas públicas de combate à homofobia nas escolas possam ser justificadas com referência a argumentos de princípio, isto é, caso possam se fundamentar em direitos, há razões extremamente plausíveis para sua implementação. Caso se tratem somente de uma questão de política, não haveria razões constitucionais suficientemente persuasivas para sua sustentação em um plano além do jogo político. Passemos a este ponto. 


\section{CAPÍtulo 2 - POlíticas PÚblicas de COMBATE À HOMOFOBIA NAS ESCOLAS À LUZ DA TEORIA CONSTITUCIONAL: a teoria dos direitos}

A exortação para discutir a diferenciação entre questões de princípio e questões de política requer pensemos no papel exercido pelos direitos fundamentais em nosso sistema constitucional. Em primeiro lugar, emerge a controvérsia constitucional fundamental ao discutirmos políticas contramajoritárias: a tensão entre direitos fundamentais de uma minoria e a política das maiorias, redutível, em termos de discussão conceitual, à famigerada tensão entre constitucionalismo e democracia (seção 2.1). A mais célebre e divulgada defesa dos direitos fundamentais estabelecidos constitucionalmente apela para sua importância contramajoritária, ao imunizarem as minorias dos possíveis humores destrutivos das maiorias, e para sua primazia diante dos valores coletivos (seção 2.2). A teoria dos direitos de Ronald Dworkin ${ }^{87}$ auxilia-nos a compreender os direitos fundamentais dentro de um sistema coerente de normas em constante tensão, apoiado em uma comunidade regida pelo ideal de integridade (seção 2.3). Se os direitos fundamentais são corretamente descritos, nos termos dworkinianos, como trunfos das minorias em relação às maiorias - se esta é a melhor maneira de vislumbrarmos o constitucionalismo de nossas comunidades políticas - e possuem a devida centralidade em nossa vida democrática e a primazia sobre a política ordinária, quais direitos, finalmente, políticas públicas de combate à homofobia nas escolas poderiam promover? (capítulo 3). Neste capítulo, exporemos as premissas da teoria constitucional que adotamos a fim de entender qual a relação das políticas públicas de combate à homofobia nas escolas com o constitucionalismo do Estado democrático de direito.

\subsection{A relação entre constituição e política}

A relação entre o princípio republicano de que todas as decisões que regem a comunidade política como um todo devem ser tomadas pelo povo, aquele que detém o poder soberano de decidir os rumos da vida pública (princípio da democracia), e entre o princípio liberal de que o poder do povo soberano deve obedecer a certas restrições e limites protetores dos direitos de eventuais minorias, ameaçadas por maiorias potencialmente tirânicas (princípio do constitucionalismo) tem sido conturbada e problemática desde as discussões

\footnotetext{
${ }^{87}$ Enquanto obras que realizam uma profícua reconstrução e análise crítica do pensamento jurídico de Ronald Dworkin, destacaríamos HABERMAS (2003a, pp. 241-295) e CARVALHO NETTO; SCOTTI (2011).
} 
sobre a fundação do até então inédito modelo de república constitucional resultante na federação estadunidense ${ }^{88}$ Seria possível contornar o chamado dilema contramajoritário?

De uma perspectiva republicana radical, uma constituição seria um artefato essencialmente antidemocrático, na medida em que remove certas matérias do processo decisório político-democrático e imuniza-as do alcance das maiorias, impossibilitando estas de decidir, por meio de suas próprias regras e procedimentos, quais são seus objetivos coletivos atuais e de que modo os perseguirão (SUNSTEIN, 1988, pp. 327, 338; ELSTER, 1988, p. 1; HOLMES, 1988, p. 195). Críticas que tomam por base a democracia em um sentido radicalmente literal (a democracia como governo do povo) estabelecem o constitucionalismo como seu conceito antitético, como um dispositivo limitador de poderes e, por essa razão, inerentemente não democrático. De fato, à primeira vista o constitucionalismo assinala os limites substantivos ou procedimentais, em certo sentido autoimpostos, às decisões da maioria política. Constituições então serviriam a duas funções cumuladas: proteger os direitos individuais e criar obstáculos para as mudanças políticas (ELSTER, 1988, pp. 2-3); exprimiriam uma profunda desconfiança acerca da democracia. O poder majoritário deveria ser limitado à medida que as maiorias poderiam usar despudoradamente seus poderes em um sentido antirrepublicano, privatizando o Estado e utilizando-o para favorecer seus próprios interesses, e em um sentido antiliberal, violando os direitos de alguns indivíduos para promover os interesses de outros ou o bem-estar geral da coletividade (Idib., pp. 5-6). Os direitos insulariam certos bens jurídicos fundamentais (tais como a vida, a liberdade, a propriedade, a igualdade política e a igual dignidade de todos os indivíduos) dos cálculos utilitários voltados à aferição do máximo de felicidade geral possível. A relação ente constitucionalismo e democracia é analogamente transposta às relações diádicas entre regras e discricionariedade, razão e paixão, segurança jurídica e instabilidade institucional, conservação e mudança.

\footnotetext{
${ }^{88} \mathrm{O}$ federalismo foi uma inovação institucional, em termos de forma de Estado, cunhada pela novel República dos Estados Unidos da América. Nasceu em virtude da Constituição de 1787. Anteriormente, houve a proclamação de independência das 13 colônias britânicas da América, em 1776, momento em que cada colônia constituía um Estado soberano e independente, reunindo-se, através de um tratado internacional (Artigos da Confederação) na Confederação dos Estados Americanos, a qual permitia a denúncia do tratado e o direito de retirada (secessão) a qualquer momento. Para se fortalecer diante da antiga metrópole inglesa, os Estados da Confederação reuniram-se na Convenção da Filadélfia, quando fundaram a federação dos Estados Unidas da América (esta, não permitindo direito de secessão); cada Estado cedia sua soberania para um órgão central (a União), cada qual passando a ser autônomo. Conferir, a esse respeito: FERNANDES (2015, pp. 729 e ss.); CARVALHO NETTO (2003, p. 162); PAIXÃO, BIGLIAZZI (2011, pp. 91-172).
} 
Mas por que um governo independente, autônomo e majoritário aceitaria estar précomprometido e autocomprometido (self-binding) com restrições constitucionais elaboradas e promulgadas por gerações anteriores? Qual o fundamento desse tipo de limitações intergeracionais - com que direito uma geração compromete seus sucessores a observar certas regras? Se o povo é verdadeiramente soberano, por que motivo deveria aceitar se submeter a uma estrutura constitucional preexistente que limita seu poder de inovação e reforma e torna mais dificultosa e sistemática a discussão sobre suas ações presentes e futuras? Afinal, como aponta Klaus GÜNTHER (2009, p. 220) com certa perplexidade:

\footnotetext{
O poder absoluto do legislador soberano deve ser vinculado a uma permissão dos direitos humanos que devem proteger primariamente o indivíduo contra o poder político. Mas se, inversamente, isto significar que os direitos humanos gozam de primazia normativa perante o processo legislativo político, este não mais seria soberano.
}

Contra a ideia de pré-compromisso (pre-commitment), críticos defensores de uma concepção republicana radical de democracia aduzem que uma sociedade não pode se comprometer a limites postos por seus predecessores, pois cada geração teria um direito ilimitado de decidir sobre seu próprio presente, planejar seu futuro, escolher como perseguir suas metas coletivas e remodelar as instituições sob as quais vive, tal como dito no aforismo “a democracia é o governo dos vivos; os mortos não possuem direitos”. O único consentimento plausível que legitima qualquer sistema de governo seria o consentimento expresso dos vivos, o que tornaria certos tipos de contrato social intertemporal, tais como uma constituição, ilegítimos e desprovidos de validade. A democracia seria um arranjo orientado para assegurar a capacidade humana fundamental de aprendizado e autocorreção, pois, com base no aperfeiçoamento técnico, no progresso científico, no desenvolvimento moral e no acúmulo cultural, a uma comunidade seria permitido sempre inovar, mudar e reformar seu sistema jurídico sem entraves e restrições infligidas por uma estrutura normativa herdada (HOLMES, 1988, pp.201-202).

Todavia, tal concepção falha em perceber a natureza de dependência mútua do constitucionalismo e da democracia. Não há constituição sem democracia, pois, do contrário, haveria uma espécie de paternalismo autoritário. Não há democracia sem constituição, pois, do contrário, haveria uma espécie de autoritarismo popular majoritário. Democracia e constituição estão em uma relação não paradoxal, mas de tensão constitutiva: através do equilíbrio entre esses dois princípios são geradas formas legítimas de existência política. 
Tanto a autonomia pública defendida por uma compreensão republicana-rousseauniana dos direitos $^{89}$ quanto a autonomia privada preconizada por uma compreensão liberal-kantiana dos direitos ${ }^{90}$ falham em perceber o caráter equipromordial da autonomia pública e da autonomia privada. Como afirmamos em outra oportunidade, com base na teoria do discurso de HABERMAS (2003a), “os sujeitos do direito compreendem-se como autores e destinatários de um modelo de autolegislação que pressupõe os direitos humanos como condições formais da institucionalização jurídica da vontade política discursivamente formada, na qual soberania do povo se converte em direito legítimo" (AMARAL JR., 2013, p. 57).

Assim caminha a observação de Stephen HOLMES (1988, p. 197) de que a existência de uma indissolúvel contradição entre constitucionalismo e democracia seria um dos principais mitos do pensamento político moderno, na medida em que constituições podem favorecer as democracias e aumentar - não restringir - a liberdade pública de seus cidadãos. Além de conter ou se sobrepor às leis infraconstitucionais, o direito constitucional também contribui para a autoafirmação e para a emancipação; ao assegurar direitos fundamentais, a Constituição é, a um só tempo, coercitiva e emancipatória (ROSENFELD, 2003a, p. 92). A democracia é um regime de governo em si mesmo paradoxal: ela ao mesmo tempo deve se fundamentar na soberania popular e requer seja defendida dessa mesma soberania, ou do contrário poderia dar lugar a um governo popular descontrolado que eliminaria o próprio ideal democrático (ELSTER, 1985, p. 13). Uma democracia livre de restrições é autodestrutiva. Indivíduos estão sujeitos a paixões, miopias e equívocos, e podem se unir em grupos e compor uma maioria temporária para tomar decisões das quais se arrependerão depois;

\footnotetext{
89 "Kant sugere um modelo de ler a autonomia política mais próximo do liberalismo. O princípio do direito é uma lei geral de liberdade que se legitima numa etapa anterior ao próprio estabelecimento do contrato social e, portanto, da autonomia política: os 'direitos naturais' que precedem a vontade do legislador soberano são fundamentados moralmente. Ele partiu da ideia de que ninguém, no exercício de sua autonomia política, poderia aderir a leis que ao mesmo tempo privam seus direitos naturais que protegem a autonomia privada. $\mathrm{O}$ argumento liberalista mostra-se problemático no seguinte aspecto: os direitos humanos são, em sua origem, estritamente horizontais, portanto só podem ser atribuídos e concedidos mutuamente por todos os homens, cabendo aos próprios titulares dos direitos decidir sobre seu conteúdo" (AMARAL JR., 2013, p. 56).

90 "Rousseau, por seu turno, aproximou-se de uma posição republicana e interpretou a ideia da autolegislação numa linha mais ética do que moral, compreendendo a autonomia como a realização consciente da forma de vida de um povo concreto, dissolvendo o conteúdo normativo dos direitos humanos no modo de realização da soberania popular. E essa visão pressupõe necessariamente um 'ethos homogêneo de uma comunidade particular que, com suas decisões majoritárias, discrimina ou exclui minorias' (GÜNTHER, 2009, p. 225), não alcançando o telos da democracia. O conteúdo normativo dos direitos humanos não pode surgir, como pensa Rousseau, na forma de leis gerais e abstratas, que permitem simplesmente regulamentações que garantem a todos as mesmas liberdades subjetivas. 'O visado nexo interno entre soberania do povo e direitos humanos reside no conteúdo normativo de um modo de exercício da autonomia política, que é assegurado através da formação discursiva da opinião e da vontade' (HABERMAS, 2003a, p. 137). É através da vinculação aos direitos humanos que se possibilita a institucionalização jurídica da democracia, com inclusividade e abertura do processo democrático" (AMARAL JR., 2013, p. 56).
} 
precisam ser protegidos de sua própria tendência ao arrependimento. Objetar-se-ia que essas gerações poderiam prescindir de constituições e simplesmente mudar suas decisões tão logo se arrependam delas. Esse argumento falha em considerar o fato de que nem todas as decisões imprudentes podem ser desfeitas: a suspensão de liberdades civis e a mal planejada execução de políticas públicas deixam impactos irreparáveis em vítimas - sejam indivíduos ou grupos, seja a comunidade como um todo - que não poderão ser integralmente compensadas mais tarde. Estabilidade institucional e segurança jurídica são valores defensáveis em si mesmos, pois permitem o planejamento a longo prazo. Como aponta Jon ELSTER (Id., p. 6):

\footnotetext{
O constitucionalismo se apoia então nos raros momentos na história de uma nação em que discussões principiológicas profundas transcendem a barganha e as negociatas da política majoritária do dia-a-dia, o objeto desses debates sendo os princípios que deverão restringir decisões majoritárias futuras.
}

Julgamos haver pelo menos sete razões encadeadas e interdependentes pelas quais uma democracia se torna mais forte com o estabelecimento de uma constituição e, portanto, o constitucionalismo acaba por ser um instrumento não de limitação, mas de produção, atribuição e organização dos poderes democráticos, uma técnica promotora (enabling) da democracia. Essas razões apontam para a complexa complementariedade de tais princípios e à sua irredutibilidade unilateral. Constituições: I) possibilitam a existência de uma comunidade democrática; II) permitem que a comunidade democrática escolha e persiga seus objetivos de maneira racional; III) resguardam a comunidade democrática de sua autodestruição; IV) protegem as condições essenciais da legitimidade e do funcionamento da democracia: os direitos políticos; V) aprimoram a qualidade da democracia; VI) são projetos orientados para o futuro que permitem tensões e dissensos razoáveis e VII) são uma aquisição evolutiva das civilizações ocidentais. Senão vejamos.

(I) Constituições possibilitam a existência de uma comunidade democrática. Por meio do ato de dar a si mesmo uma constituição, o povo cria uma comunidade de cidadãos, atribuindo uns aos outros direitos recíprocos e decidindo como regularão sua vida através dos meios do direito positivo (HABERMAS, 2003a, p. 158). Estabelecer uma assembleia constituinte significa, antes de tudo, criar um espaço destinado a desenhar uma estrutura com apoio na qual a comunidade tornará possível deliberar, pela primeira vez, a respeito de sua vontade, já que sem tal espaço não seria possível a elaboração de uma vontade coletiva em termos republicanos. As vontades preexistentes apriorísticas, egoísticas e autorreferenciadas apenas poderiam fazer jus a uma forma de solidariedade requerida para a integração social 
com o auxílio de algum tipo de patriotismo constitucional ${ }^{91}$. Em sociedades pluralistas e em alguma medida liberais, é insustentável que uma constituição estabeleça propósitos coletivos pré-fixados, motivo pelo qual uma constituição pluralista rejeita uma política baseada na virtude em prol de uma estrutura básica procedimental que estimula as discussões públicas e deixa um espaço considerável para a elaboração da vontade política, desde que respeitados alguns princípios de justiça que necessariamente façam parte da compreensão moral ${ }^{92}$ adotada por aquela comunidade política. Uma constituição que gere um pré-compromisso baseado em catálogos de valores exaustivos eleitos de antemão seria uma imposição paternalista inaceitável para uma democracia marcada pelo legítimo pluralismo de valores. É a ordem constitucional quem cria o poder soberano do povo.

\section{(II) Constituições permitem que a comunidade democrática escolha e persiga seus} objetivos de maneira racional. Uma constituição não obstrui, antes favorece a realização de objetivos coletivos. Nesse sentido as restrições constitucionais fortalecem e proporcionam a democracia: "a constituição é um instrumento de autogoverno, uma técnica pela qual os cidadãos governam a si mesmos, sem a qual uma comunidade complexa não poderia administrar seus próprios assuntos" (HOLMES, 1988, p. 230). Duas das funções de um sistema de direitos consistem em $a$ ) estabilizar expectativas normativas de comportamento e b) tornar possível a decisão sobre como uma comunidade irá buscar seus próprios objetivos (HABERMAS, 2003a). (a) Nenhum indivíduo decidirá se engajar na perseguição das metas compartilhadas pela comunidade a não ser que seja garantido que os outros também farão sua

\footnotetext{
${ }^{91}$ Com o conceito de patriotismo constitucional, Habermas refere-se a um tipo de integração social adequado para sociedades em que há desacordos morais e éticos básicos sobre valores, interesses e ambições comuns, às chamadas sociedades pós-nacionais, não solidarizadas no nível de uma cultura comum mas, ao contrário, no nível da diversidades de formas de vida. O patriotismo constitucional apela para a união de seus cidadãos independentemente de seus antecedentes culturais ou de suas heranças étnicas, baseado na interpretação de princípios constitucionais universais, reconhecidos dentro do contexto de uma determinada história e tradição localizada. Nessa perspectiva, o Estado-nação é substituído por um Estado democrático de direito que configura uma "nação de cidadãos" baseada numa cultura política comum, capaz de gerar solidariedade entre estranhos: “(...) não é necessário amarrar a cidadania democrática à identidade nacional de um povo; porém, prescindindo da variedade de diferentes formas de vida culturais, ela exige a socialização de todos os cidadãos numa cultura política comum" (HABERMAS, 2002, p. 289).

${ }_{92}$ A despeito de uma controvérsia entre processualismo e substancialismo, autores como Habermas e Dworkin concordam que alguns princípios básicos, com caráter substantivo, fazem parte de um sistema constitucional legítimo, bem como concordam que esses princípios não podem ser tão detalhados ao ponto de impedirem a deliberação pública sobre as reais necessidades presentes, que se dá dentro do processo político. Ambos, embora guardem um compromisso mais ou menos forte com o republicanismo (mais forte no caso de Habermas), se comprometem igualmente com uma relação mais ou menos forte (mais forte no caso de Dworkin) entre o sistema jurídico e o sistema moral. A situação ideal de fala da teoria do discurso de HABERMAS (2003a) contém em seu cerne princípios de autonomia pública e privada derivados do raciocínio e dos discursos morais. Na visão de DWORKIN (2011, p. 380), "quando rejeitamos o modelo dos dois sistemas e vemos a lei como uma parte distinta da moral política, temos de tratar os princípios estruturantes especiais que separam a lei do resto da moral política como princípios políticos que necessitam de uma leitura moral”.
} 
devida parte, isto é, seja assegurada reciprocidade. Para a realização dos objetivos, os membros de uma sociedade política devem aquiescer a respeito de arranjos jurídicos que comprometerão suas próprias vontades e impedirão que estas se desviem para propósitos antissociais. ${ }^{93}(b)$ Constituições não apenas limitam, mas criam e organizam o poder e o canalizam numa certa direção. O princípio da separação dos poderes ${ }^{94}$ é vulgarmente visto como um mecanismo de freios e contrapesos (checks and balances) que atua para conter os abusos suscetíveis da concentração do poder. Embora seja forçoso reconhecer sua função negativa, tal visão restritiva poderia obscurecer sua função positiva igualmente relevante: a tripartição das instituições do Estado e a atribuição de respectivas funções é um mecanismo de divisão do trabalho que racionaliza a atuação estatal e permite distribuições e organizações do poder mais eficientes (HOLMES, 1988, p. 228). Mais além, constituições evitam que os cidadãos e as cidadãs, ao deliberar sobre suas necessidades, tenham dispendiosas discussões sobre princípios abstratos, ${ }^{95}$ pois, ao tomarem os princípios constitucionais como ponto de partida, estarão desincumbidas para empreender a política do presente. Uma constituição é uma estratégia indireta da comunidade para o autocomando, para a autolegislação coletiva.

\section{(III) Constituições resguardam a comunidade democrática de sua autodestruição.}

Este argumento assume a tendência de um governo da maioria de se degenerar em um governo despótico. Se há exclusão sistemática e definitiva das minorias do processo político, se sua capacidade de articulação política e de oposição é reduzida a nada, certamente um governo desse tipo extrapolaria qualquer conceito sóbrio de democracia. E as gerações subsequentes têm aceitado viver sob uma constituição legada porque esta é um dispositivo útil para prevenir a autodestruição coletiva e garantir que o interesse público do Estado não será usurpado pelo interesso privado das facções que o governam. Ademais, o ato de promulgar uma constituição protege as gerações mais remotas de um possível enrijecimento autoritário ${ }^{96}$

\footnotetext{
93 A Constituição da República Federativa do Brasil (CF-88) declara como seus objetivos fundamentais a construção de uma sociedade livre, justa e igualitária; garantir o desenvolvimento nacional; erradicar a pobreza e a marginalização; e promover o bem de todos, sem preconceitos de origem, raça, sexo, cor, idade e quaisquer outras formas de discriminação (art. $3^{\circ}$ e seus incisos).

94 A CF-88 institui o princípio da separação de poderes Legislativo, Executivo e Judiciário, “independentes e harmônicos entre si”, em seu art. $2^{\circ}$.

95 Conferir o argumento de HOLMES (1988, p. 216): "Se nós podemos tomar por concedidos certos procedimentos e instituições fixadas no passado, poderemos realizar nossos objetivos presentes mais efetivamente do que poderíamos caso fôssemos constantemente desviados por recorrentes necessidades de estabelecer uma estrutura básica para a vida política. Uma constituição herdada pode ser 'possibilitadora' da democracia [self-enabling].

96 Tal proteção se dá mediante dispositivos constitucionais imodificáveis, conhecidos popularmente como "cláusulas pétreas", não alteráveis sequer por meio de emenda constitucional regularmente aprovada pelo Poder Constituinte derivado. $\mathrm{Na} \mathrm{CF}-88$, o art. $60, \S 4^{\circ}$, trata desses dispositivos: "Não será objeto de deliberação a
} 
da parte das gerações subsequentes: por meio de uma constituição, uma geração $A$ pode ajudar uma geração $C$ a não ser escravizada pela geração $B$, a não padecer da suspensão das liberdades democráticas (Ibid., p. 239).

(IV) Constituições protegem as condições essenciais da legitimidade e do funcionamento da democracia: os direitos políticos. Este é o argumento mais sério para compreendermos em que sentido os direitos não são contrários à democracia, mas sim trunfos contra as maiorias que ambicionam deturpar os meios democráticos. A democracia é mais do que a imposição da vontade majoritária e mais do que a simples agregação de preferências individualísticas pré-políticas - como sugere uma concepção estritamente liberal-pluralista. A Constituição promove a deliberação sobre preferências ao invés de meramente implementálas (SUNSTEIN, 1988, p. 352). A democracia é um regime baseado na discussão pública, a qual não poderia funcionar legitimamente - isto é, partindo-se do pressuposto de que todas as cidadãs afetadas por essa discussão terão suas razões devidamente ouvidas e consideradas na ausência do reconhecimento de certos direitos aos sujeitos deliberantes. A soberania popular é sem sentido na ausência de regras que organizam o debate público (HABERMAS, 2003a; HOLMES, 1988, p. 233). Os direitos constitucionais protegem a discussão através da garantia da liberdade de fala, de associação, de imprensa, dos direitos políticos de votar e ser votada, incluindo-se o direito de consentir com ou dissentir das políticas governamentais. ${ }^{97} \mathrm{O}$ desacordo público é um instrumento essencial do governo popular, pois compõe o complexo argumentativo pelo qual decisões gerais são geradas e auxilia no incremento da prudência e da qualidade dessas decisões e na profunda revisão reflexiva da estrutura constitucional vigente. Direitos que garantem a oposição são uma pré-condição essencial para a formação da opinião pública e para a "descoberta da vontade política". "Direitos, em outras palavras, não são designados meramente para a proteção das minorias, mas também para a correção e a instrução da maioria" (HOLMES, 1988, p. 234).

proposta de emenda tendente a abolir: I) a forma federativa de Estado; II) o voto direto, secreto, universal e periódico; III) a separação de Poderes; IV) os direitos e garantias individuais".

97 Vejamos a presença desses direitos no direito constitucional positivo brasileiro. No art. $5^{\circ}$ e seus incisos, dentre outros direitos, estão consagradas as liberdades democráticas: "IV - é livre a manifestação do pensamento, sendo vedado o anonimato"; "VI - é inviolável a liberdade de consciência e de crença, sendo assegurado o livre exercício dos cultos religiosos e garantida, na forma da lei, a proteção aos locais de culto e suas liturgias"; "VIII - ninguém será privado de direitos por motivo de crença religiosa ou de convicção filosófica ou política (...)"; "IX - é livre a expressão da atividade intelectual, artística, científica e de comunicação, independentemente de censura ou licença"; "XIV - é assegurado a todos o acesso à informação e resguardado o sigilo da fonte, quando necessário ao exercício profissional"; "XVII - é plena a liberdade de associação para fins lícitos, vedada a de caráter paramilitar" etc. Os direitos políticos de sufrágio estão dispostos nos arts. de 14 a 17: “Art. 14, caput: A soberania popular será exercida pelo sufrágio universal e pelo voto direto e secreto, com valor igual para todos (...)". 
(V) Constituições aprimoram a qualidade da democracia. Com o auxílio dos direitos supracitados, cidadãs e cidadãos podem fiscalizar a atividade governamental e à maioria é resguardado limitar seus próprios poderes a fim de permanecer capaz de aprender continuamente. Uma constituição pode criar um regime adequado à capacidade humana de autocorreção, tornando, ao postular determinadas regras procedimentais, o aprendizado público possível. “A democracia constitucional é o mais 'humano' sistema político porque ela desenvolve a habilidade dos indivíduos e das comunidades de reconhecer seus próprios erros" (Ibid., p. 240).

(VI) Constituições são projetos orientados para o futuro que permitem dissensos $e$ tensões razoáveis. O processo constituinte continua para muito além do momento de dissolução da assembleia constituinte. As constituições não são monolíticas, pois estão sujeitas a permanentes transformações tanto $(a)$ formais quanto $(b)$ interpretativas. (a) A faculdade de emendar o texto constitucional (o poder constituinte derivado) está disponível aos parlamentos na figura de mecanismos permanentes de reforma, desde que respeitados certos procedimentos dispostos, ${ }^{98}$ geralmente mais solenes do que os requeridos para a alteração das leis infraconstitucionais, e eventualmente um núcleo de disposições imodificáveis (as chamadas cláusulas pétreas). ${ }^{99}$ Deste modo, uma maioria insatisfeita com certas limitações constitucionais pode se mobilizar com o intuito de compor o coeficiente necessário para alterar o texto constitucional. Se os legisladores se abstêm de exercer seu direito fundamental de emenda, emitem um consenso tácito ${ }^{100}$ a respeito das normas em vigor. (b) Os constituintes não pretenderam regular exaustivamente toda a vida democrática, deixando uma larga margem de discricionariedade para o debate público a respeito não só do trabalho legislativo, como também da interpretação dos dispositivos constitucionais $\left(\right.$ DWORKIN, 2003) ${ }^{101}$. Os direitos são redigidos em linguagem por vezes abstrata, ambígua,

\footnotetext{
${ }^{98}$ Conforme art. 60, $\$ 2^{\circ}$, da CF-88: “A proposta [de emenda constitucional] será discutida e votada em cada Casa do Congresso Nacional, em dois turnos, considerando-se aprovado se obtiver, em ambos, três quintos dos votos dos respectivos membros".

${ }^{99}$ Ver nota de rodapé no 96 , supra.

100 O consenso tácito é uma razão suficiente para legitimar a aquiescência a uma ordem constitucional. O princípio de que nenhuma obrigação deve ser assumida sem consentimento expresso não é defensável, como demonstra SANDEL (2013) ao dissertar sobre as obrigações comunitárias. De fato, os benefícios devem ser distribuídos da mesma forma que as cargas que eles supõem: se uma geração se beneficia das realizações provindas da adoção de uma estrutura constitucional e das vantagens resultantes da cooperação ao longo do tempo, é razoável admitir que essa geração tem bons motivos para aceitar o pré-compromisso gerador dos ganhos. Conferir HOLMES (1988, p. 219).

101 DWORKIN (2003, pp. 192-205) diferencia entre uma concepção da Constituição de detalhes e uma concepção da Constituição de princípios. Revisitando a história constitucional estadunidense, argumenta que o constituinte comprometeu as gerações futuras não com uma lista ad hoc de regras a cumprir, mas com um catálogo de princípios que devem ser atualizados segundo leituras morais.
} 
evasiva e conflitante, consignados em textos sujeitos a múltiplas interpretações (ROSENFELD, 2003a, p. 18), de modo a deixar às gerações futuras, tanto aos legisladores quanto aos juízes e à sociedade civil, a possibilidade de debater sobre o real significado dos princípios constitucionais naquele momento histórico, o significado mais apurado que atenda tanto às necessidades coletivas em ascensão quanto à evolução moral e cultural experimentada por um povo tendo em vista a dinâmica transformativa e reflexiva da história. A tessitura aberta do direito não é um problema, mas um ponto de partida (CARVALHO NETTO, 2002, p. 68). O estabelecimento de uma identidade constitucional (ROSENFELD, 2003a, pp. 17) pressupõe um entrelaçamento do passado dos constituintes com o presente das atuais gerações e com o futuro das gerações vindouras. O sujeito constitucional é sempre aberto, comporta um hiato carente de reconstrução, o qual jamais se completa ou se define de uma vez por todas (Ibid., p. 26).

(VII) Constituições são uma importante conquista evolutiva das civilizações ocidentais. Esta é uma razão muito menos teórica do que prática, derivada do aprendizado histórico. Seguindo a lição maquiavélica sobre o caráter pedagógico da história, podemos observar o fracasso das experiências de regimes de governo populares que solaparam o constitucionalismo. ${ }^{102}$ A história nos ensina que uma constituição sem democracia é um abuso e uma democracia sem constituição é autoritarismo. Se um modelo de governo baseado na adoção de formas constitucionais tem triunfado há alguns séculos nas sociedades ocidentais, sempre invocado para curar os traumas da transição após regimes autoritários, há boas razões para que, para além de defesas teóricas consistentes, seja recomendável adotá-lo caso queiramos viver em uma comunidade política justa e que promova eficientemente seus objetivos com base no debate público informado, livre e igualitário.

Por todas essas razões, soa um falso truísmo afirmar que constitucionalismo e democracia travam uma batalha sem tréguas e sem possibilidade de conciliação. Nem faz sentido a dicotomia de Cass R. Sunstein entre provisões constitucionais democráticas

\footnotetext{
102 Por todos, pensemos no exemplo da Alemanha Nazista do III Reich. Embora contasse com grande respaldo popular e com a figura de um líder carismático que supostamente unificava os ideais nacionais, nesse período cometeram-se terríveis atrocidades institucionalizadas contra seres humanos e reiteradas violações dos direitos mais básicos das minorias, notadamente de minorias étnicas, raciais, religiosas e sexuais. Pela própria extensão do catálogo de direitos promulgado na Lei Fundamental Alemã de 1948 - promulgada posteriormente ao fim da Segunda Guerra Mundial e ao período do holocausto - e com sua defesa das instituições democráticas, vê-se que a experiência alemã nos ensina exemplarmente sobre os altos custos de um governo populista descontrolado, quando levado aos seus extremos.
} 
(relativas a estrutura) e antidemocráticas (relativas a direitos). ${ }^{103}$ Mesmo o direito de privacidade - um típico direito não público em sua origem - funciona para desencadear uma democracia mais robusta, uma vez que permite que cidadãs e cidadãos formem sua opinião e sua vontade sem constrangimentos exógenos e, assim, contribuam para uma esfera pública plural e repleta de instigantes tensões constitutivas.

Semelhante oposição conceitual é ressignificada por Ronald Dworkin por meio da distinção entre uma concepção majoritária (estatística) e uma concepção comunitária (de parceria) da democracia. A primeira afirma que "as pessoas se governam a si próprias quando a maioria delas, e não um grupo menor, conserva um poder político fundamental" (DWORKIN, 2011, p. 391); baseia-se na "meta de que as leis geradas pelo complexo processo democrático e os cursos de ação por ele seguidos sejam, no fim, os aprovados pela maioria" (DWOKRIN, 2006, p. 24). A segunda afirma que "governo democrático significa um governo não pela maioria das pessoas que exercem autoridade sobre todas as pessoas, mas pelas pessoas que agem como um todo enquanto parceiras" (DWORKIN, 2011, p. 392); baseia-se na premissa de que "decisões coletivas sejam tomadas por instituições políticas cuja estrutura, composição e modo de operação dediquem a todos os membros da comunidade, enquanto indivíduos, a mesma consideração e o mesmo respeito" (DWORKIN, 2006, p. 26). De acordo com a concepção majoritária, a ação coletiva é gerada pela soma estatística das ações individuais de cada um, ainda que sem nenhum comprometimento com a coletividade ou sentimento de que estão agindo enquanto grupo. De acordo com a concepção comunitária, a ação coletiva pressupõe a atuação de um agente coletivo, ${ }^{104}$ o grupo, de modo que as ações individuais devem ter o sentido de honrar o pertencimento (DWORKIN, 2006, p. 30), a filiação moral fundante da relação entre um indivíduo e um grupo, baseada no igual status de dignidade conferido a todos os membros e base da responsabilidade solidária.

\footnotetext{
${ }^{103}$ SUNSTEIN (1988, p. 328) argumenta que existem dispositivos constitucionais relativos a estruturas e relativos a direitos. Os primeiros destinam-se a garantir uma certa concepção de democracia através da limitação do poder de grupos privados poderosos e facciosos ou da diminuição da probabilidade de que os representantes políticos venham a perseguir seus interesses próprios ao invés do interesse público - o exemplo típico seria o arranjo da tripartição de poderes; na medida em que visam a garantir que o governo agirá no interesse público podem ser entendidos como democráticos. Os segundos são arquitetados para cercar certas áreas do controle majoritário, protegidas pelo conceito de direitos; estes podem ser democráticos em sentido literal quando em suas raízes protegem a democracia, como os direitos de voto e as liberdades de fala e associação, enquanto outros podem ser antidemocráticos no sentido de exprimirem uma descrença na democracia, com os direitos de privacidade e propriedade.

${ }^{104} \mathrm{O}$ agente coletivo possui uma vontade coletiva distinta da vontade de cada um dos membros da comunidade individualmente considerados. Mas a "vontade coletiva" é um espaço de constantes tensões e conflitos pelo seu domínio. Nesse sentido, diferencia-se do conceito de "vontade geral" de Rousseau, o qual pressupõe uma certa homogeneidade ética da comunidade. Ver HABERMAS (2003a).
} 
Para entender tal distinção, é esclarecedor voltar-se ao conceito dworkiniano de direito: o direito é um complexo de normas que autorizam o uso do poder coercitivo pela comunidade política condensada na figura do Estado. Nesse sentido, é a comunidade um agente supra-individual e distinto de cada indivíduo em particular e de seus respectivos interesses e convicções morais, éticas e políticas, o qual age de forma legítima quando, como consequência de suas decisões, cumpre o princípio abstrato da igualdade: age com igual respeito e preocupação por cada uma das parceiras da comunidade (por isso, dizer-se um governo democrático de parceria). A ideia de parceria é a única explicação plausível capaz de justificar o ingresso, a permanência e o engajamento em uma sociedade democrática, bem como a obediência às suas decisões coercitivas, mesmo nas circunstâncias nas quais estas desagradam a alguma pessoa em particular.

Tal desacordo pode ser explicado pela distinta compreensão implícita em cada concepção a respeito do fundamento de uma democracia: a igualdade política. A ideia de soberania do povo não faz sentido se desconsideramos que cada cidadão e cada cidadã devem pelo menos exercer alguma participação na formação e no controle das decisões coletivas. A primeira leitura da igualdade política requer o igual impacto, isto é, o mesmo peso do poder político de cada cidadã na decisão final da comunidade. A segunda leitura requer que o poder político da comunidade seja dividido não necessariamente em partes iguais, mas de maneira que trate as pessoas como iguais (DWORKIN, 2011, p. 396).

A primeira não consegue explicar a democracia representativa: uma vez instauradas eleições para cargos representativos, as representantes eleitas deterão muito mais poder político para decidir os rumos da atividade pública do que qualquer eleitora; admiti-la seria reduzir a democracia a um mero mecanismo eleitoral, visão muito pouco convincente e moralmente injustificável. E mesmo durante o pleito eleitoral, em comunidades amplas, formadas por milhares de eleitoras, o impacto de cada voto em particular é irrisório: a decisão de uma pessoa de votar de uma forma ou de outra não aumentaria em grau estatisticamente significativo a probabilidade de sucesso de sua preferência. Soma-se a isso a influência externa, por parte de grandes corporações econômicas ou associações culturais ou religiosas, exercida tanto durante o processo eleitoral quanto durante a tomada de decisões pelas instituições, a qual minimiza ainda mais o impacto das preferências de uma cidadã comum. Em suma, o igual peso na votação só pode assegurar a igualdade de entrada (input), mas nunca a igualdade de saída (output), pois o poder substantivo resultante refletirá apenas a 
predominância das preferências da maioria. O único sentido plausível da igualdade política apela para os resultados do processo político, não para sua instauração e composição:

\begin{abstract}
A igualdade política tem a ver não com o poder político, mas com o estatuto político. A democracia confirma, da forma mais dramática, a preocupação e o respeito iguais que toda a comunidade, enquanto depositária do poder coercivo, tem por cada um dos seus membros. A democracia é a única forma de governo, na ausência de um governo por sorteio, que confirma a preocupação e o respeito iguais na sua lei mais fundamental (DWORKIN, 2011, p. 398).
\end{abstract}

A própria regra majoritária para a tomada de decisões políticas mais ordinárias não se justifica pelo reclame de igual impacto ao poder político de cada cidadã, mas sim porque, a não ser que se possa fazê-lo de forma fundamentada, negar o igual peso a cada votante nega a ela o estatuto de igual dignidade. A igualdade política, portanto, não é uma relação existente entre os indivíduos considerados um a um, mas uma relação entre cidadãs em seu conjunto coletivamente consideradas como "povo" - e suas governantes, um estado no qual a cidadania controla o governo (DWORKIN, 2006, p. 44).

A concepção majoritária define a democracia de um modo meramente formal, a partir da adoção de um procedimento para gerar decisões, qual seja, a regra da tomada de decisões obrigatórias pela contagem dos votos e a promulgação da vontade do maior número de pessoas. Ela sustenta uma teoria da democracia que prescinde de uma teoria da justiça: a regra da maioria nem sempre gera resultados justos. Sua opositora, a concepção comunitária, define a democracia de um modo substantivo, vinculando as decisões em um governo a critérios substantivos de legitimidade. E uma vez que apenas a correção da decisão garante a filiação moral, uma democracia comunitária precisa ir além da premissa majoritária, pois se empenha na política a partir da preocupação com a justiça dos resultados (MENDES, 2008, p. 57). "Os cidadãos de uma sociedade republicana (...) estendem sua experiência moral para a política, e disputam nesta esfera diferentes concepções de bem comum” (Ibid., p. 61).

A defesa contemporânea da posição majoritária é feita por Jeremy Waldron ${ }^{105}$ em uma tentativa de conceber uma teoria da democracia baseada na teoria da autoridade e neutra em relação à justiça, pois esta seria matéria de "desacordos políticos" em virtude dos quais a objetividade moral seria impossível senão pelo recurso a uma autoridade decisória. Por causa do desacordo moral básico, a igualdade deveria restringir-se à sua dimensão procedimental de

105 As principais obras de Waldron dedicadas ao assunto são "Law and Disagreement" e "The Dignity of Legislation". Uma exposição sucinta de suas principais contribuições para a discussão sobre democracia, apresentada a partir de sua discordância de Dworkin, pode ser vista em MENDES (2008, pp. 81-110). 
igual peso no voto de cada um. "O método da decisão majoritária tenta dar a cada indivíduo o maior peso possível, compatível com o peso igual de todos" (Ibid., 2008, p. 98). A proposição de Waldron padece do erro crucial de que padecem todas as outras defesas do majoritarismo: a desconsideração do problema contramajoritário. Para isso, Waldron precisa passar por uma série de omissões analíticas, de modo a desconsiderar: a má-fé das intenções de agentes que deliberam politicamente; a opressão por vezes imperceptível que deturpa o processo político; a violência impositiva presente mas encoberta em falsos consentimentos; a desigualdade de influência nas esferas da legislação; uma séria consideração da questão contramajoritária, não como uma questão de minoria vencida em assembleias esporádicas, mas como uma questão de minorias sistematicamente excluídas; ${ }^{106}$ a distinção entre participar de uma decisão e ser respeitada pela mesma decisão; e a distinção entre preferências generalizáveis e preferências cuja avaliação cabe apenas ao indivíduo. Todo o argumento peca em uma visão inadvertidamente idealizada de uma pessoa moral imparcial e autônoma capaz de alteridade, e em uma visão dos direitos como uma questão de opinião, interesse, vontade ou constatação, na qual estes perdem sua função de garantia.

Apenas a segunda concepção se vale de uma teoria da justiça mais rigorosa que requer os resultados do processo democrático sejam também justos no sentido de que tratem todos os indivíduos com igual respeito e igual consideração, e não apenas que se dê tudo à maioria e nada à minoria. Quando uma comunidade decide a respeito dos direitos das minorias subvalorizadas, estas tendem a ser prejudicadas sistematicamente pelas maiorias, fato que diminui a legitimidade das decisões na medida em que trata algumas pessoas de maneira desigual em virtude de preconceitos. Portanto, apenas a segunda concepção oferece maior proteção constitucional às minorias, e, por esse motivo, é mais apta a gerar estabilidade, ao garantir um bem-estar geral mais permanente, pois endossado pela satisfação de todas e todos, e não apenas dos grupos majoritários. O povo, detentor da soberania, abrange não somente uma maioria, mas todas e todos agindo comunitariamente.

O princípio da igualdade de consideração e respeito de cada cidadã implica a exigência de condições pelas quais uma democracia não se tornará uma oligarquia disfarçada sempre

${ }^{106}$ HABERMAS (2002, p.170) se vale do conceito de "minorias inatas", as quais têm lugar quando "uma cultura majoritária, no exercício do poder político, impinge às minorias a sua forma de vida, negando assim aos cidadãos de origem cultural diversa uma efetiva igualdade de direitos", para referir-se ao que preferimos denominar minorias estruturais, isto é, minorias que são sistematicamente excluídas da política e da cultura de uma determinada sociedade persistentemente através dos tempos. Preferimos evitar o termo "inatas", pois este pode criar uma falsa noção de que alguns grupos naturalmente estão subordinados a outros, quando, como já demonstramos, a demarcação de minorias com relação a maiorias faz parte de uma ampla disputa de poder dentro de arranjos sociais específicos que permitem, em tese, algum grau de resistência e transformação. 
pronta para atender exclusivamente aos interesses dos grupos mais poderosos; logo, sujeita o governo democrático a condições mais exigentes que a simples regra da maioria. Essas são as condições democráticas: condições de participação moral ${ }^{107}$ em uma determinada comunidade política. Tais condições determinam o modo como um indivíduo deve ser tratado enquanto membro moral de uma comunidade. Para DWORKIN (2006, pp. 37-40), diante das decisões coletivas de uma comunidade deve ser garantida a toda pessoa participação, reciprocidade e independência com relação a ela. A participação ${ }^{108}$ é favorecida pelas chamadas liberdades democráticas de crença, pensamento e expressão, pelas liberdades políticas de votar e ser votada, que conferem às cidadãs algum grau de possiblidade de modificar as decisões coletivas. O interesse na decisão é garantido à medida que ela expressa igualdade de consideração para com os interesses de todos os membros da comunidade; isto porque a participação moral acarreta reciprocidade, de modo que nenhum indivíduo deve ser cobrado a cumprir as obrigações comunitárias a menos que ele seja também, pelo menos indiretamente, beneficiário delas. Por este motivo costuma-se designar como ilegítima uma sociedade onde as necessidades e perspectivas das minorias são desprezadas. A independência com relação à decisão ${ }^{109}$ traduz-se na ideia de independência moral: uma comunidade não pode determinar o que cidadãs e cidadãos devem pensar a respeito de suas próprias políticas, mas, pelo contrário, deve propiciar condições que lhes permitam chegar às suas próprias convicções em matéria de ética ou política, e, com base nelas, perseguir seus projetos de vida.

As condições democráticas coincidem com as restrições constitucionais mencionadas acima, que constrangem a política da maioria e estabelecem um pré-compromisso a ser obedecido pela comunidade. Chamaremos de democracia constitucional a concepção de democracia coerente com as restrições constitucionais e com o princípio abstrato da igualdade. A democracia constitucional é uma contribuição à teoria política que elimina as

\footnotetext{
${ }^{107} \mathrm{O}$ conceito de participação moral de Dworkin é uma identificação do tipo de vínculo entre um indivíduo e um grupo pelo qual seja justo que este seja considerado responsável pelos atos daquele. De acordo com a concepção comunitária, um membro moral de uma comunidade política reconhece os atos desta como um ato seu, mesmo caso seja contrário a tal ato, desde que sua dignidade derivada do princípio da igualdade abstrata seja considerada. Conferir DWORKIN (2006, p. 35).

${ }^{108}$ A reivindicação de que todo indivíduo deve ter alguma parte nas decisões coletivas não significa que não poderá haver outras vias para a ação coletiva. Na teoria de Dworkin, admite-se que questões sobre os direitos de minorias sejam deixadas para fóruns antimajoritários, isoladas dos procedimentos majoritários, tais como os tribunais constitucionais. Essa é a tônica da defesa de Dworkin da prática de judicial review.

${ }^{109} \mathrm{O}$ regime democrático marcado pela concepção comunitária da ação coletiva não é totalitário, mas liberal. Apesar de cobrar do indivíduo certas atitudes e posturas devido ao tratamento que recebe em virtude de seu status de membro pertencente à comunidade (unidade de responsabilidade), reconhece sua independência com relação aos julgamentos (unidade de julgamento). O indivíduo apenas filia-se a uma comunidade caso seja respeitada sua independência moral, sua capacidade de julgar a partir de sua convicção política (MENDES, 2008, pp. 65-66). Essa visão é coerente com a visão liberal da pessoa enquanto agente moral.
} 
tradicionais contradições entre constitucionalismo e democracia e esclarece como o princípio segundo o qual todo o poder político pertence ao povo e o princípio segundo o qual cada cidadã do povo deve ser tratada com igual consideração e respeito fazem parte de um mesmo complexo arranjo comunitário.

Um Estado que adote o constitucionalismo rege-se por algo além de uma teoria da supremacia das maiorias, mas por uma compreensão de que homens e mulheres têm direitos morais contra o Estado e contra a coletividade. A democracia, mesmo a despeito das barreiras constitucionais, tende a potencializar o poder de influência dos grupos hegemônicos e a reproduzir o interesse da maioria com relação a questões econômicas, morais, éticas, religiosas e culturais controvertidas. Para que as decisões do processo político resguardem o conteúdo de justiça consistente com o princípio da igualdade abstrata, os direitos fundamentais assumem proeminência no ordenamento jurídico-constitucional enquanto elementos contramajoritários da argumentação política.

\subsection{O caráter contramajoritário dos direitos fundamentais}

No calor de discussões contra positivistas (no Direito) e utilitaristas (na Ética), Ronald Dworkin introduz a categoria de direitos que funcionam como proteção do indivíduo perante o poder coletivo da comunidade política. Direitos são garantias disponíveis às minorias de que, mesmo quando derrotadas em fóruns políticos, alguns de seus interesses fundamentais, reconhecidos pelo sistema constitucional, serão respeitados não obstante a fúria destrutiva de uma maioria orientada em direção a metas sociais ou enviesada por valores coletivos excludentes. A visão dos direitos como trunfos é uma concepção liberal ${ }^{110}$ do sistema constitucional: não reivindica o estatuto de neutralidade comum à boa parte das teorizações do

\footnotetext{
${ }^{110}$ Dworkin estava em busca da melhor leitura da história constitucional estadunidense, a qual seria, em sua avaliação, a leitura liberal. Há diversas concepções do liberalismo, sendo que Dworkin filia-se àquilo que se poderia chamar "liberalismo igualitário". O liberalismo igualitário toma como conceito o princípio da igualdade abstrata: todos os indivíduos de uma comunidade devem ser tratados com igual consideração e com igual respeito. Embora sua teoria seja gestada no ambiente político anglo-saxão, durante os debates da segunda metade do século XX, sobretudo nos Estados Unidos e na Inglaterra, acreditamos que sua teoria do direito traz infindáveis contribuições para se pensar no papel dos direitos fundamentais e nos seus modos de interpretação em qualquer sistema constitucional que esteja comprometido com a ligação entre direitos fundamentais individuais e proteção de minorias. Não seria diferente no caso do Brasil: possuímos uma novel tradição constitucional erguida sobre a primazia dos direitos fundamentais do indivíduo, incluindo-se os direitos negativos do indivíduo perante o Estado e os direitos necessário à realização de uma correta concepção de justiça social. Dworkin tem sido largamente adotado por doutrinadoras, juristas, advogadas, juízas e profissionais do direito em geral, e principalmente por professoras e acadêmicas do Direito nas faculdades de graduação e pósgraduação pelo Brasil afora. Sua influência sobre a atual fase de nosso constitucionalismo é inegável e tem, até agora, rendido frutíferos resultados em termos da garantia de direitos fundamentais.
} 
direito antecedentes. Acreditamos que a situação humana no mundo cultural é hermenêutica: ${ }^{11}$ a escolha de um ponto de vista a partir do qual julgamos determinados problemas nos orienta na construção dos princípios edificadores das teorias. A condição hermenêutica mina a fracassada tentativa de êxito das "ciências neutras". Adotamos o ponto de vista dworkiniano porque a tese dos direitos como garantias das minorias fornece um esquema para pensarmos a legitimidade e a relevância de políticas públicas contramajoritárias, tais como as políticas públicas de combate à homofobia nas escolas. As lutas por liberdade identitária são, em última análise, lutas liberais pelo direito de ter respeitada a diferença de sua própria individualidade. A seguir, exporemos os aspectos centrais da tese dos direitos ${ }^{112}$ de Dworkin.

Os direitos são consistentes com e derivados de uma concepção mais abrangente de (a) ética, (b) moral política e (c) direito, assentadas em uma teoria da justiça baseada na unidade do valor. ${ }^{113}$ Ética, moral e direito são três distintos departamentos do valor. Antes de tudo, é preciso ressaltar que os conceitos em Dworkin são interpretativos, ou seja, não têm um estatuto semântico ou lógico, mas se abrem para a intepretação de uma prática à sua melhor luz pela comunidade segundo o ideal de integridade (à qual nos dedicaremos mais tarde). A primeira diferenciação básica deve ser feita entre ética e moral: ${ }^{114}$ aquela é um padrão para as condutas do eu consigo mesmo, sobre como nós próprios devemos viver, enquanto esta tratase de uma padrão do eu para com os outros, sobre como devemos tratar os outros e sobre nossas obrigações em relação a eles. O objetivo de Dworkin é desenvolver uma teoria na qual

\footnotetext{
${ }^{111}$ As ciências sofreram uma verdadeira reconstrução a partir do "giro linguístico" operado na Filosofia desde os primórdios do século XX, marcado pela filosofia da linguagem de Ludwig Wittgenstein e pela hermenêutica filosófica de Hans Georg Gadamer (ver COSTA, 2008, p.136). A partir de então, a apreensão da realidade escapa de uma ontologia fenomênica extrínseca à compreensão humana e passa a ser vista como linguisticamente construída. Resulta da adoção do giro linguístico como paradigma compreensivo a afirmação da reflexividade do conhecimento, o qual passa a ser exposto a um permanente debate público de suas premissas, encarado como "precário, contingente e aprimorável. Seus fundamentos são sempre históricos e datados", construtos sociais historicamente conquistados (CARVALHO NETTO; SCOTTI, 2011, p. 22).

${ }^{112} \mathrm{~A}$ tese dos direitos é constituída de outras seis subteses. As subteses anti-utilitaristas assentam que os direitos são (1) objetivos políticos individuados, (2) demandas de justiça e (3) trunfos dos indivíduos contra metas sociais da comunidade. As subteses anti-positivistas assenta que os direitos são (4) construídos mediante interpretação coerentista, (5) prévios ao direito positivo e (6) incluídos no direito através dos princípios. Ver COELHO (2013, p. 22).

${ }^{113}$ Em seu último livro, "Justice for hedgehogs", DWORKIN (2011) se esforça para delinear uma teoria totalizante (uma teoria "para ouriços") que integrasse todos os conceitos de filosofia prática que ele vinha desenvolvendo desde o início de sua carreira, como moral, direito, ética, política, igualdade, liberdade, interpretação, única resposta correta etc. Dworkin chega a uma teoria baseada na unidade do valor, em que todos os conceitos acima mencionados se articulam segundo a ideia de que fazem parte de questões valorativas interrelacionadas.

114 À guisa de exemplificação, HABERMAS (2003a, p. 23) trabalha os conceitos de ética e moral sob outro critério interpretativo. A moral seria universalista e teria a ver com interesses generalizáveis, seguindo-se a trilha aberta pela lição kantiana do imperativo categórico. A ética, por sua vez, seria contextualizada e teria a ver com aquilo que é bom para um indivíduo ou uma comunidade.
} 
ética e moral estão integradas de modo interpretativo, em que as responsabilidades éticas e as responsabilidades morais se determinam umas às outras (DWORKIN, 2011, pp. 199, 210).

(a) Viver bem ${ }^{115}$ é a responsabilidade ética fundamental: somos responsáveis por viver bem pelo simples fato de existirmos enquanto criaturas humanas e de nos ter sido confiado algo de valor - a vida - ao nosso cuidado (Ibid., p. 204). Em um projeto de integração de concepções éticas e morais, evidentemente a moral é essencial para se viver bem. Por isso, viver bem está condicionado a dois princípios que funcionam como requisitos e, juntos, oferecem uma concepção da dignidade humana: (i) respeito próprio e (ii) autenticidade. $\mathrm{O}$ respeito próprio $(i)$ implica em que cada pessoa deva considerar sua vida um bem importante objetivamente e engajar-se em torná-la um projeto bem sucedido. A autenticidade (ii) aduz que cada pessoa tem responsabilidade especial de viver bem segundo uma narrativa coerente que ela própria aprova, segundo os valores que ela considera certos para si e para suas circunstâncias. O primeiro princípio, isoladamente, remete a uma visão ética completamente estranha ao liberalismo: a noção de responsabilidade ética. Afinal, o que tem marcado uma importante oposição entre liberais e comunitaristas no debate estadunidense é justamente o reclame de independência ética por parte dos liberais, ${ }^{116} \mathrm{o}$ fato de que a comunidade não pode forçar o indivíduo a assimilar qualquer convicção ética em particular, mas, ao contrário, deve deixar-lhe um espaço incólume para que ele próprio elabore e realize seu projeto de vida. $\mathrm{O}$ segundo princípio ingressa na concepção de dignidade justamente sustentando a pessoalidade, a autenticidade das concepções sobre viver bem, e nesse sentido a ética de Dworkin não trai seu legado liberal. "A autenticidade exige que, na medida em que se devem tomar decisões sobre a melhor utilização a dar à vida de uma pessoa, as decisões devam ser tomadas pela pessoa cuja vida está em causa" (Ibid., p. 219), sem que ela tenha de aceitar o juízo de outrem sobre os valores ou objetivos que sua vida deve exprimir. O conceito de dignidade traz esclarecimentos sobre o modo como devemos tratar os outros, isto é, sobre a agência moral.

(b) Ideias sobre viver bem ajudam a definir responsabilidades morais. O princípio ético segundo o qual minha vida é objetivamente importante, transposto para a problemática moral - como tratar os outros - fornece um primeiro critério para o conteúdo das

\footnotetext{
115 Viver bem não significa necessariamente ter uma vida boa. Viver bem está sujeito a certas condições derivadas da noção interpretativa de dignidade humana que se transporta, inclusive, para a moral. Uma pessoa pode alcançar o bem-estar material ou uma carreira bem sucedida atentando contra a dignidade de seus semelhantes e passando por cima dos limites do respeito ao outro. Nesse caso, poderá ter tido uma vida boa, que o satisfaça, mas sem dúvida terá falhado no esforço de viver bem. Essa distinção remonta a uma dicotomia familiar no pensamento moral: a diferença entre o certo e o bom, entre cumprir um dever ou realizar uma ação que traga benefício a si próprio. Ver DWORKIN (2011, p. 203).

${ }^{116}$ Conferir, a esse respeito, CITTADINO (2009) e AMARAL JR. (2013).
} 
considerações morais: o fato de minha vida ser objetivamente importante é um razão para eu pensar que a vida de qualquer outra pessoa também o é. Em termos gerais, o princípio da importância objetiva coincide com o princípio da humanidade kantiano ${ }^{117}$ do valor de cada vida humana em si mesma, a negação da instrumentalização da vida. Esse princípio moral básico prescreve que "tratar as pessoas com o respeito que atribuímos a nós próprios exige, no mínimo, que não reivindiquemos para nós próprios direitos que não atribuímos aos outros e que não imponhamos deveres aos outros que não aceitamos para nós próprios" (Ibid., p. 274). Há um passo de nível que vai da moral pessoal à moral política: aquela trata mais genericamente do que devem as pessoas fazer umas pelas outras, enquanto esta trata mais especificamente do que devem os membros de uma comunidade política fazer uns pelos outros, das obrigações e dos direitos que possuem reciprocamente, os quais são especiais e diferenciados de suas obrigações com relação a qualquer pessoa que não partilhe da mesma filiação comunitária (Ibid., p. 336).

(c) Na teoria de Dworkin, o direito é um ramo da moral política, ${ }^{118}$ uma questão sobre o que devemos com relação aos outros que fazem parte de nossa comunidade. Os direitos políticos - direitos mais gerais de uma comunidade política - têm fundamento no conceito de obrigação política. A obrigação política deriva de um relacionamento existente entre concidadãos; nesse nível surge uma entidade coletiva distinta e artificial por meio da qual cidadãs e cidadãos cumprem suas obrigações políticas, através da passagem do meramente pessoal ao político: o Estado. A moral política dispõe justamente sobre o que devemos aos outros enquanto cidadãs e cidadãos quando agimos em nome dessa pessoa coletiva e artificial. Enquanto indivíduos abstratamente considerados, no nível da moral pessoal, possuímos responsabilidades, ao passo que, enquanto membros de uma comunidade política, no nível da moral política, possuímos direitos. Os direitos políticos são interesses que todos nós temos contra o Estado - contra o "nós" coletivo - relevantes ao ponto de que devam ser protegidos até mesmo das políticas que melhorariam as condições das pessoas como um todo e o bemestar da comunidade. Nesse ponto surge a ideia de direitos como trunfos diante de outras justificações que seriam adequadas para a ação política coletiva (Ibid., pp. 335-337).

\footnotetext{
117 Dworkin realiza uma reconstrução da filosofia moral kantiana e argumenta que "as afirmações de Kant são mais convincentes quando compreendidas como uma teoria interpretativa que estabelece uma ligação entre a ética e a moral" (2011, p. 274).

118 DWORKIN (2011, pp. 410-411) declina de sua antiga visão segundo a qual direito e moral eram sistemas separados, mas que interagiam de alguma forma, em prol da visão de que o direito é uma parte da moralidade política, de modo que as normas jurídicas que uma comunidade promulga devem ser guiadas e limitadas pelos princípios de justiça derivados de compreensões morais. Apenas em casos de rara excepcionalidade uma comunidade estaria autorizada a proclamar normas injustas.
} 
Quando de sua divergência com relação à teoria tradicional positivista-utilitarista do direito, Dworkin salienta que o modelo de regras endossado pelo positivismo jurídico é insuficiente para resolver casos difíceis. Grosso modo, positivismo, ${ }^{119}$ empregado dessa forma, significa a crença de que o direito emana diretamente de convenções explícitas com força de lei, promulgadas pela autoridade competente (teste de pedigree com base na regra de reconhecimento) anteriormente ao momento de resolução de casos judiciais. Essas convenções retiram seu fundamento de validade da autoridade, e são nesse aspecto indiferentes à moral. Para decidir casos difíceis, isto é, casos em que há uma controvérsia sobre a aplicação de padrões jurídicos pré-concebidos ao caso concreto, seja devido à vagueza da linguagem da regra jurídica pertinente, seja pela impertinência de tal regra ou pela própria inexistência de um padrão disponível, juízas, juristas e advogadas recorrem ${ }^{120}$ a padrões que não são necessariamente regras, mas funcionam como princípios ou políticas. ${ }^{121}$ Princípios e políticas são distintas categorias em que se embasam a justificação política em geral (DWORKIN, 2007, p. 130); diferenciam-se da seguinte forma: políticas são padrões que estabelecem "um objetivo a ser alcançado, em geral uma melhoria em algum aspecto econômico, político ou social da comunidade", ao passo que princípios estabelecem um padrão que deve ser observado "porque é uma exigência de justiça ou equidade ou alguma outra dimensão da moralidade" (Ibid., p. 36) e porque "a decisão respeita ou garante um direito de um indivíduo ou de um grupo" (Ibid., p. 129). Um objetivo político ${ }^{122}$ - que pode

\footnotetext{
${ }^{119} \mathrm{O}$ critério central de distinção entre uma teoria positivista e uma teoria não positivista do direito é a relação que o direito guarda com o sistema moral; no caso de uma teoria não positivista, a vinculação entre direito e moral é necessária, enquanto tal vinculação é meramente acidental ou contingente ou até impossível na visão do positivismo jurídico (ver ALEXY, 2005). Nesse sentido ver também DWORKIN, 2011 (pp. 410-411), que aponta uma grave falha na visão apartada dos dois sistemas: "Quando encaramos o direito e a moral como dois sistemas de normas separados, não há uma perspectiva neutral a partir da qual as relações entre estes dois sistemas, supostamente separados, possam ser determinadas" (Ibid., p. 411). A grande deficiência do positivismo enquanto ciência e método seria o ideal fantástico da neutralidade.

${ }^{120}$ Dworkin chega a tal conclusão ao analisar dois casos emblemáticos decididos pela Suprema Corte dos Estados Unidos, Riggs contra Palmer e Henningsen contra Bloomfield Motors, Inc., nos quais as regras explícitas que disciplinavam a matéria foram afastadas (no caso Riggs) ou estendidas (no caso Henningsen) sob a justificação de princípios morais reconhecidos como subjacentes à prática jurídica do país (2007, pp. 37-38).

${ }^{121}$ As leis e regras inscritas no direito constitucional são quase sempre vagas e devem ser interpretadas antes de poder-se aplicá-las aos casos concretos. Por isso, a atividade judiciária aparentemente consiste em criar um novo direito, como se fosse uma delegação do poder legislativo. Essa é a tônica da crítica ao chamado "ativismo judicial". Porém, essa visão ignora a distinção entre argumentos de política e argumentos de princípio. Uma juíza deve recorrer somente aos segundos, enquanto os primeiros - juntamente com os segundos - devem fundamentar decisões políticas somente da legislação. Quando decidem com base em princípios, juízas fomentam a democracia e fazem jus à visão dworkiniana do Judiciário como fórum do princípio. "As decisões judiciais nos casos civis (...) são e devem ser, de maneira característica, geradas por princípios, e não por políticas" (DWORKIN, 2007, p. 132).

122 Tanto princípios quanto políticas são objetivos políticos em sentido genérico, pois contam a favor de uma decisão política que promove ou protege um certo estado de coisas. Mas direitos políticos são objetivos políticos individuados, isto é, requerem a concessão de liberdades, oportunidades particulares ou recursos para determinados indivíduos. Metas coletivas, pelo contrário, são objetivos políticos não individuados: apenas
} 
ser, em sentido amplo, um princípio ou uma política - tem sua natureza determinada tendo como referência seu lugar e sua função no âmbito de uma determinada decisão (Ibid., p. 145). Os direitos que funcionam como trunfos perante as políticas podem derivar de regras ou de princípios.

Princípios são estruturas da argumentação jurídica diferentes das regras em alguns pontos: não apresentam consequências jurídicas que se seguem automaticamente quando as condições são dadas, não pretendem estabelecer condições que tornam sua aplicação necessária, mas enunciam razões que conduzem o argumento numa certa direção. "Ao afirmarmos que um princípio particular é um princípio do nosso direito, é que ele, se for relevante, deve ser levado em conta pelas autoridades públicas, como [se fosse] uma razão que inclina numa ou noutra direção" (Ibid., p. 42). Ao contrário das regras, princípios não contêm sua condição de aplicação. Espalhados pelo texto das constituições modernas, tais como no da Constituição do Brasil, ${ }^{123}$ há princípios enunciados direta e explicitamente. Porém, parte significativa dos casos difíceis submetidos à jurisdição constitucional é resolvida com o auxílio de ou com base exclusiva em princípios reconhecidos em sede judicial, por via de interpretação, embora não escritos no texto constitucional.

Princípios e regras, no entanto, compartilham do caráter deontológico das normas do dever-ser jurídico. O próprio fato de as regras serem obrigatórias para as juízas é, em si mesmo, um princípio: o princípio segundo o qual as decisões judiciais serão tomadas de acordo com o direito vigente. Princípios são leis no mesmo sentido em que regras o são e, do mesmo modo, uma constelação de princípios pode autorizar direitos e impor obrigações jurídicas. “(...) Uma obrigação jurídica existe sempre que as razões que sustentam a existência de tal obrigação, em termos de princípios jurídicos obrigatórios de diferentes tipos, são mais fortes do que as razões contra a existência dela" (Ibid., p. 71). Além do mais, princípios podem justificar mudanças da regra de direito em vigor quando uma juíza considera que tal

ambicionam o aumento do bem-estar da comunidade como um todo, mesmo sem aumentar o benefício de algum indivíduo em particular. Ver DWORKIN (2007, pp. 142-143).

123 Poderíamos reconhecer uma lista não exaustiva de princípios, apenas a título de exemplo, presentes na Constituição brasileira: todos os princípios constantes do art. $1^{\circ}$ (soberania, cidadania, dignidade da pessoa humana, valores sociais do trabalho, livre iniciativa, soberania popular, representação política), do art. $2^{\circ}$ (separação de poderes independentes e harmônicos entre si), do art. $3^{\circ}$ (não discriminação), bem como a grande parte dos direitos estabelecidos no art. $5^{\circ}$ (igualdade perante a lei, igualdade entre homens e mulheres, reserva legal, liberdade de expressão, liberdade de consciência, liberdade de crença e de religião, privacidade, inviolabilidade do domicílio e de correspondências, liberdade profissional, liberdade de imprensa, acesso à informação, liberdade de associação, direito de propriedade, função social da propriedade etc.). Todos os princípios exemplarmente citados têm em comum o fato de não disporem, em si mesmos, sobre suas condições de aplicação em casos concretos nem sobre o peso que possuem quando confrontados com outros princípios ou com objetivos coletivos em sentido estrito. 
mudança ${ }^{124}$ favorecerá algum princípio; bem como podem justificar o abandono da doutrina solidificada, quando ela se opuser a alguns padrões importantes (Ibid., p. 60).

Enquanto as regras se baseariam na lógica do tudo-ou-nada - ou uma regra é aplicável ao caso e este deve ser a ela subsumido, ou não é aplicável -, princípios operariam na dimensão do peso. ${ }^{125}$ Admitindo que, por definição, um direito não é absoluto, seu peso será definido pela sua capacidade de suportar a concorrência com outros princípios porventura mais adequados ao caso ou com metas sociais de extrema urgência e relevância. Segue-se que um direito é definido enquanto tal na medida em que não for menos importante que todas as metas sociais, em que tenha certo peso contra as metas em geral e que resista em face delas, excetuadas aquelas de extrema urgência e relevância (Ibid., p. 144). Mas a tese dos direitos apresenta um paradoxo ${ }^{126}$ caso seja lida a partir de um estatuto criterial ou empírico ou, ao contrário, de um olhar normativo: deve-se perguntar "se o fato de aquele objetivo ter sido preterido por uma meta social não urgente poderia ser usado como fundamento de reprovação ou crítica à decisão que o tivesse feito" (COELHO, 2013, p. 36). Para avaliar criticamente essa decisão, Dworkin precisa pressupor um pano de fundo intuitivo comum que subjaz à tese como um todo (Ibid., p. 38). Direitos são reconhecíveis dentro da estrutura de uma teoria política coerente, utilizada, ainda que intuitivamente, por uma autoridade pública no momento de uma decisão (DWORKIN, 2007, p. 145).

\footnotetext{
${ }^{124}$ Porém, não é qualquer princípio que pode ser invocado para justificar a mudança; caso contrário nenhuma regra estaria a salvo, e não poderíamos afirmar a obrigatoriedade de regra alguma. É preciso que haja princípios com maior importância que outros (DWORKIN, 2007, p. 60). "Os princípios possuem uma dimensão que as regras não têm - a dimensão do peso ou importância. (...) Aquele que vai resolver o conflito tem de levar em conta a força relativa de cada um" (Ibid., p. 42).

${ }^{125}$ Importante registrar a diferença entre a concepção do direito como integridade e o método do sopesamento ou ponderação aplicado pela jurisprudência dos valores do Tribunal Constitucional Alemão e descrito por ALEXY (2008). A ponderação pressupõe a consideração dos direitos como mandados de otimização, realizáveis com maior ou menor intensidade a depender das circunstâncias jurídicas e fáticas. Os direitos constitucionais fundariam uma ordem concreta de valores e seriam aplicados como se valores fossem. HABERMAS (2003a, pp. 314-330) é um crítico contumaz dessa tendência; comparando as abordagens de Alexy e Dworkin, condena a equiparação de princípios e valores (para a defesa de tal equiparação, ver ALEXY (2008)) na medida em que princípios, enquanto normas, têm caráter deontológico de uma obrigação incondicional, ao passo que valores têm caráter teleológico e são aplicados segundo ordens de preferências de acordo com os objetivos coletivos da comunidade. A mesma crítica é reforçada por CARVALHO NETTO; SCOTTI (2011).

${ }^{126}$ COELHO (2013) aponta um paradoxo na tese dos direitos: "ela é tratada como requisito conceitual para que algo seja um direito, mas isto torna conceitualmente impossível que direitos sejam preteridos por metas sociais não urgentes e frustra o propósito crítico da tese dos direitos” (p.22). Assim, a subtese dos direitos deve ser "entendida como fixando que os direitos tornam erradas as decisões que os preterem por metas sociais não urgentes, interpretação que tem a vantagem de manter o sentido conceitual e crítico, moral e criterial, da subtese dos direitos como trunfos (...)" (p. 23). Com efeito, uma leitura unicamente criterial ou uma leitura alternativa, unicamente normativa, da tese dos direitos frustrariam o propósito de Dworkin em sua própria enunciação. $\mathrm{O}$ empreendimento de Dworkin visa a reconhecer as proposições jurídicas que podem ser consideradas verdadeiras tendo em vista a prática jurídica de uma comunidade e, nesse sentido, direitos são reconhecidos na medida de sua resistência às metas sociais. Mas uma compreensão meramente empirista viola o propósito crítico da tese, o sentido de que ela possa servir de crítica às decisões que não consideram os princípios reconhecidos na tal prática. As dimensões empírica e normativa não se bastam a si mesmas, unilateralmente consideradas.
} 
Direitos podem ser diferenciados segundo categorias. Em primeiro lugar, a tese dos direitos distingue entre direitos preferenciais e direitos institucionais. Os primeiros fornecem uma justificação para decisões políticas tomadas pela sociedade em abstrato, enquanto os segundos - os direitos genuínos - oferecem uma justificação para uma decisão tomada por alguma instituição política específica (Ibid., p. 145). Em segundo lugar, distingue entre direitos abstratos e direitos concretos. Os primeiros indicam um objetivo político no interior de um enunciado que nada diz respeito ao modo como deverá ser pesado em circunstâncias particulares ou harmonizado com outros objetivos políticos; são os típicos direitos da retórica política, utilizados tão somente como razão em favor da aplicação de direitos concretos. Os segundos são objetivos políticos definidos com precisão e clareza a respeito de seu peso (Ibid., p.146). Adiante, será adicionada uma relevante categoria específica de direitos políticos (political rights): os direitos jurídicos (legal rights). Estes são direitos que recebem um estatuto especial da comunidade, geralmente concebidos para efetivar um direito político preexistente, a ponto de serem promulgados por um corpo legislativo e estarem aptos a justificar decisões exigidas pelas cidadãs individuais com base neles, até mesmo aberta a possiblidade de acionar uma instituição judicial para lhe dar cumprimento efetivo (DWORKIN, 2011, p. 339). As juízas devem decidir casos difíceis por meio da negação ou confirmação de direitos institucionais que sejam também direitos concretos e direitos jurídicos.

A concepção de direitos como trunfos fornece um teste de legitimidade política a ser aplicado a uma dada comunidade. Assim Dworkin sintetiza o princípio da legitimidade:

\footnotetext{
Uma comunidade política só tem força moral para criar e impor obrigações aos seus membros se os tratar com preocupação e respeito iguais; ou seja, se as suas políticas tratarem as vidas dos seus membros como igualmente importantes e respeitarem as suas responsabilidades individuais sobre as suas próprias vidas. Este princípio da legitimidade é a origem mais abstrata dos direitos políticos (Ibid., p.338).
}

O princípio moral da dignidade - o princípio de que a vida de cada pessoa tem um valor objetivo - aplicado à moralidade política gera o princípio da igualdade abstrata, direito fundamental do qual derivam todos os demais direitos políticos.

Finalmente, cabe ressaltar, direitos são conceitos interpretativos, pois não podem ser determinados a partir de uma análise neutra com relação a seu valor ou importância (Ibid., pp. $353,358)$. A moralidade política funciona como um argumento em favor dos direitos que as 
cidadãs defendem possuir (DWORKIN, 2007, pp. 158-159). Cabe às juízas interpretar textos e precedentes à luz de uma teoria coerente da moralidade política, tendo em vista o ideal de integridade que respeite a história institucional, a justiça e a equidade. Adequação à história institucional, considerações de justiça e considerações de equidade são elementos centrais na tarefa interpretativa geradora de direitos. Examinemos, a seguir, essa afirmação com maiores detalhes.

\subsection{Leitura moral da Constituição e direito como integridade}

Os dispositivos constitucionais que estabelecem direitos fundamentais geralmente têm estrutura principiológica: possuem uma textura semântica aberta e estão construídos por meio de uma linguagem moral abstrata. DWORKIN (2006, p. 10) sugere que tais princípios devem ser compreendidos tomando como referência o significado atribuído vulgarmente a essa linguagem, difundido pela moralidade política comunitária. Os princípios constitucionais, portanto, fariam apelos à interpretação de princípios morais abstratos. Esse método particular de ler e executar uma constituição política recebe o nome de leitura moral: "a leitura moral propõe que todos nós - juízes, advogados e cidadãos - interpretemos e apliquemos esses dispositivos abstratos considerando que eles fazem referência a princípios morais de decência e justiça" (Ibid., p. 2). A leitura moral insere a moralidade política no âmago do direito constitucional e das decisões sobre quais obrigações e direitos temos: qualquer interpretação competente da Constituição deve reconhecer que alguns direitos constitucionais se destinam a impedir que as maiorias sigam suas próprias convicções a respeito do que a justiça requer (DWORKIN, 1999, p. 450). Mas a moral política é intrinsecamente incerta e controversa e, por esse motivo, todo sistema de governo deve determinar quais autoridades serão competentes para identificar esses princípios. Em última instância, a leitura moral é empreendida pelas autoridades judiciais, quando, ao decidir casos constitucionais difíceis embasados em princípios que apelam para a interpretação de conceitos morais, se orientam pelo dever de observar determinadas máximas e restrições derivadas da integridade, da justiça e da equidade. ${ }^{127}$

\footnotetext{
${ }^{127}$ Em Dworkin, integridade, justiça e equidade são ideais independentes e valores que podem entrar em conflito nas decisões judiciais. Embora não defina conceitualmente justiça e equidade com precisão, parece-nos que esta é a aplicação da imparcialidade, enquanto aquela é a aplicação da consideração especial da situação fática concreta de um caso singular. A integridade seria a compreensão da história institucional da comunidade como um todo coerente e harmônico. Ver DWORKIN (1999, p. 215).
} 
Alguns argumentos combatem a leitura moral; em síntese, baseiam-se na ideia de que ler uma constituição sob a ótica da moral seria um atentado ao estimado princípio da segurança jurídica: traria a incerteza típica do relativismo moral para o direito e a imprevisibilidade impediria cidadãs e cidadãos de conhecerem de antemão seus direitos e suas obrigações. A leitura moral seria um procedimento antidemocrático na medida em que alargaria sobremaneira o poder judicial de decidir o conteúdo das normas jurídicas promulgadas pelo órgão legislativo. A essas objeções, Dworkin contra-argumenta que a leitura moral nada tem de revolucionária na prática, pois é uma estratégia já rotineiramente utilizada pelas juristas e juízas estadunidenses ao interpretar a Constituição, à medida que "instintivamente partem do princípio de que a Constituição expressa exigências morais abstratas que só podem ser aplicadas aos casos concretos através de juízos morais específicos" (DWORKIN, 2006, p. 4).

Não haveria outra opção disponível para levar a cabo a intepretação de uma constituição de linguagem abstrata. Inevitavelmente, controvérsias constitucionais estão sujeitas a convicções políticas a respeito de qual é a teoria política subjacente ao sistema jurídico adotado, isto é, sobre quais princípios orientam a própria elaboração e aplicação do direito em uma comunidade política guiada por princípios. A fidelidade à Constituição exige a exposição dos princípios de moralidade política que fundamentam determinada decisão. Nesse sentido a leitura moral exige das juízas a exposição de seus juízos sobre moralidade política, na esperança de que forneçam uma franca demonstração de seus argumentos mais sinceros, fundamentados em princípios, que permitam ao público participar da discussão. A leitura moral "encoraja juristas e juízes a interpretar uma constituição abstrata à luz de sua concepção de justiça" (Ibid., p. 57). De outro modo, os fundamentos de princípio embutidos na decisão ficariam ocultos e impedidos de ser levados ao escrutínio público; nessas circunstâncias uma decisão judicial seria verdadeiramente antidemocrática.

A objeção da democracia não faz sentido uma vez já termos rejeitado a premissa majoritária como princípio democrático fundamental. Compreendido o verdadeiro caráter da democracia constitucional, a leitura moral pode ser vista como um artifício que fortalece uma democracia comprometida não só com leis aprovadas pela vontade da maioria, mas sobretudo comprometida com princípios que devem ser igualmente observados em benefício de todas as cidadãs. O direito representa uma justificativa para a ação coletiva da comunidade política e, como já deixamos claro, a comunidade política age através de uma entidade distinta de vontades e interesses individuais: o Estado. A comunidade personificada deve agir de modo 
coerente, observando os mesmos princípios de ação e aplicando os mesmos princípios a casos semelhantes. A demanda por integridade repousa, no fim das contas, no caráter coletivo da ação estatal. Dworkin distingue entre três modelos de comunidades autênticas ou genuínas: ${ }^{128}$ comunidade de fato ou de circunstâncias, comunidade de regras e comunidade de princípios. Os dois primeiros modelos rejeitam a ideia de integridade. Conforme o modelo de circunstâncias, a comunidade é apenas um acidente histórico ou geográfico e não há, pois, nenhum laço ou fidelidade entre os membros constituintes. Conforme o modelo de regras, a comunidade é apenas um acordo entre interesses conflitantes e antagônicos, condensado em regras de negociação cuja obediência esgota o conteúdo da obrigação comunitária. Já o modelo de princípios, em contraposição, pressupõe que os membros aceitam ser governados por princípios comuns e não apenas por regras criadas conforme um acordo político; a política seria então uma arena de debate sobre quais princípios a comunidade deve adotar (DWORKIN, 1999, pp. 252-254):

\begin{abstract}
Os membros de uma sociedade de princípio admitem que seus direitos e deveres políticos não se esgotam nas decisões particulares tomadas por suas instituições políticas, mas dependem, em termos mais gerais, do sistema de princípios que essas decisões pressupõem e endossam. Assim, cada membro aceita que os outros têm direitos, e que ele tem deveres que decorrem desse sistema, ainda que estes nunca tenham sido formalmente identificados ou declarados. (...) Cada um aceita a integridade política como um ideal político distinto (...), como um dos componentes da comunidade política (Ibid.,p.255).
\end{abstract}

Apenas o modelo de princípios satisfaz todas as condições de fraternidade de uma comunidade genuína numa sociedade moralmente pluralista. Sua exigência de integridade pressupõe que cada pessoa é tão digna como qualquer outra, e deve ser tratada com igual interesse, consideração e respeito, segundo uma concepção coerente do que isso significa. Uma comunidade de princípios aceita a integridade como ideal: a promessa de que o direito será elaborado, modificado, desenvolvido e interpretado de um modo coerente, fundado em princípios. Tal comunidade retira sua legitimidade política ${ }^{129}$ de uma autoridade moral

\footnotetext{
${ }^{128}$ Haveria quatro condições para uma comunidade receber o predicado de comunidade básica, autêntica ou genuína: a) reciprocidade: há uma ideia difusa de direitos e obrigações associativas mantidas entre os membros, de atitudes que eles devem pôr em prática e de sacrifícios que suas relações mútuas devem pressupor; $b$ ) obrigações especiais e pessoais, dotadas de um caráter distintivo, entre cada pessoa do grupo com relação às outras; $c$ ) o interesse de cada membro do grupo pelo bem-estar dos outros membros; e $d$ ) igualdade: a estrutura e a hierarquia do grupo devem refletir o pressuposto de que os papeis e as regras comunitárias digam respeito ao interesse de todos, de modo que a vida de nenhuma pessoa é mais importante que a de nenhuma outra (DWORKIN, 1999, pp. 241-243).

${ }^{129}$ Em Dworkin, legitimidade significa uma razão que justifica a obediência às obrigações políticas impostas pelo Estado. Um Estado é legítimo à medida que sua estrutura e suas práticas justifiquem o uso da coerção oficial e criem obrigações morais para as decisões políticas que pretende impor às suas cidadãs (1999, pp. 231-
} 
baseada na fraternidade - e não apenas do exercício coercitivo do poder, o fundamento de legitimidade em comunidades de regras. Um Estado que aceita a integridade como ideal político tem um argumento melhor em favor da legitimidade (Ibid., p. 232).

A integridade também oferece uma resolução pertinente ao problema republicano do ideal de autogoverno, segundo o qual somos não apenas destinatárias, mas também autoras das decisões políticas tomadas por nossas governantes. Tal ideal deve ser complementado com o ideal de integridade, pois, a princípio, uma cidadã não pode considerar a si mesma como autora de um conjunto de leis incoerentes. Obrigação política deixa de ser uma questão de apenas obedecer a cada uma das decisões políticas da comunidade, e torna-se um dever de fidelidade a um sistema de princípios a ser identificado por cada cidadã como sendo o sistema de princípios de sua comunidade (Ibid., p. 231).

O ideal de um governo sujeito não somente às leis, mas também a princípios, seria a grande contribuição do constitucionalismo norte-americano para o pensamento político universal, cada vez mais observado e adotado em outros países do globo. As objeções à leitura moral estariam assentadas em uma grave incompreensão do verdadeiro caráter e da importância do sistema constitucional dos Estados Unidos (DWORKIN, 2006, p. 9). O direito como integridade condena o ativismo judicial, ${ }^{130}$ pois insiste em que as autoridades judiciárias apliquem a Constituição respeitando a prática constitucional, e não a ignorando; que tomem decisões por princípio, não decisões esparsas e casuístas, por meio de uma interpretação que se submeta às tradições e à cultura política de uma nação, incluindo concepções de justiça e de equidade e virtudes políticas que possam ser identificadas de um modo coerente (DWORKIN, 1999, p. 452). Dworkin admite uma certa “intrusão judicial” em assuntos tradicionalmente reservados ao âmbito político, mas apenas na medida em que esta seja necessária à garantia e à implementação de direitos requeridos pela moral política:

De acordo com o direito como integridade, porém, essa inusitada intrusão judicial nas funções administrativas é apenas a consequência, em circunstâncias extremamente especiais e conturbadas, de uma visão perfeitamente tradicional do cargo do juiz. A tese de Hércules é, pelo menos, plausível: os juízes têm a obrigação

232). As obrigações políticas devem ser justificadas no campo da fraternidade. A obrigação central em uma comunidade política é o dever de fidelidade geral ao direito (Ibid., pp. 250-251).

130 Nas palavras de DWORKIN (1999, pp. 451-452): “O ativismo é uma forma virulenta de pragmatismo jurídico. Um juiz ativista ignoraria o texto da Constituição, a história de sua promulgação, as decisões anteriores da Suprema Corte que buscaram interpretá-la e as duradouras tradições de nossa cultura política. O ativista ignoraria tudo isso para impor a outros poderes do Estado seu próprio ponto de vista sobre o que a justiça exige. $\mathrm{O}$ direito como integridade condena o ativismo e qualquer prática de jurisdição constitucional que lhe esteja próxima". 
de fazer cumprir os direitos constitucionais até o ponto em que o cumprimento deixa de ocorrer no interesse daqueles que os direitos deveriam proteger (Ibid., p. 467).

Mister ressaltar que há relevantes restrições que as juízas devem observar ao pôr em prática a leitura moral, sobretudo os ditames de fidelidade ao texto e à integridade. I) A interpretação constitucional tem de partir do que as autoras do texto disseram. Por isso, sem dúvida alguma, o texto funciona como um limite do complexo interpretativo possível. A história é um fator pertinente num sentido particular: deve ser consultada para sabermos o que as constituintes pretendiam dizer, e não quais outras intenções elas poderiam ter ao promulgar um dispositivo constitucional (DWORKIN, 2006, p.14). As leis devem ser interpretadas com base nas convicções - e nos princípios subjacentes a essas convicções - que as autoras expressaram ao votar, e não nas intenções concretas que elas porventura tinham ou poderíamos supor elas tivessem. O direito como integridade contrasta claramente as pretensões historicistas ${ }^{131}$ na interpretação constitucional. II) A leitura moral é disciplinada pela exigência de integridade constitucional: um juízo sobre a Constituição deve ser “coerente, em princípio, com o desenho estrutural da Constituição como um todo e também com a linha de interpretação constitucional predominantemente seguida por outros juízes no passado" (Ibid., p.15). A leitura moral pede às intérpretes constitucionais que, agindo de boafé, encontrem a melhor concepção dos princípios morais constitucionais que se encaixe e se harmonize no conjunto da história institucional que fornece o pano de fundo interpretativo. A interpretação da Constituição não deve levar em conta somente o que suas próprias autoras pretendiam dizer, mas também a prática jurídica e política do passado e as noções sobre justiça do momento presente. Interpretar o direito como integridade envolve duas etapas: $a$ ) observação da prática social do direito, submetida às dimensões de adequação e justificação, e b) interpretação crítica da prática social do direito, levando em conta considerações sobre justiça e equidade. ${ }^{132}$

\footnotetext{
131 "Um historicista, dizemos agora, decidiu-se por um tipo de prestação jurisdicional que limita as interpretações aceitáveis da Constituição aos princípios que exprimem as intenções históricas dos fundadores (...). Se entendermos tratar-se de uma versão tosca da teoria da intenção do locutor, ela torna o estado de espírito daqueles que discutiram e promulgaram a Constituição um elemento decisivo sobre a interpretação a ser dada a sua linguagem abstrata. Ela identifica, para cada cláusula, um momento canônico de criação, e insiste em que aquilo que os fundadores pensavam na época, por mais peculiar que possa nos parecer agora, esgota a Constituição que temos agora. (...) Consideramos uma versão diferente e mais atraente: a de que as leis devem ser interpretadas de modo a conformar-se às convicções a partir das quais votaram seus autores" (DWORKIN, 1999, p.432). Conferir também a discussão sobre o originalismo em DWORKIN (2003, p. 184 e ss.).

${ }^{132}$ Impossível deixar de observar a semelhança das abordagens de Dworkin e de Rosenfeld a respeito da interpretação constitucional. Em Rosenfeld, a identidade do sujeito constitucional está permanentemente aberta
} 
Juízas, ao decidir um caso particular, devem considerar-se a si mesmas autoras de uma cadeia mais ampla de decisões, devem tomar sua decisão como parte integrante de uma longa história que elas têm de interpretar e dar continuidade segundo suas próprias opiniões sobre seu andamento mais coerente. Ao decidir, identificarão o princípio $X$ como fundamento de sua decisão porque $X$ pode ser reconhecido na prática institucional do passado (adequação) e porque $X$ justifica uma série de decisões que vêm sendo tomadas ao longo da história institucional (justificação).

A tarefa judicial pode ser compreendida com o auxílio da metáfora do romance em cadeia. A interpretação criativa procura atribuir um propósito ao texto submetido a exame propósito que não coincide com os propósitos particulares de suas autoras, sejam eles explícitos ou implícitos. Juízas são ao mesmo tempo autoras e críticas daquilo que interpretam; não apenas se adequam a uma linha interpretativa, mas também introduzem acréscimos a essa própria tradição. Assim Dworkin (1999, p. 276) explicita a ideia de romance em cadeia:

Em tal projeto, um grupo de romancistas escreve um romance em série; cada romancista da cadeira interpreta os capítulos que recebeu para escrever um novo capítulo (...) de modo a criar da melhor maneira possível o romance em elaboração, e a complexidade dessa tarefa reproduz a complexidade de decidir um caso difícil de direito como integridade. (...) Espera-se que os romancistas levem mais a sério suas responsabilidades de continuidade; devem criar em conjunto, até onde for possível, um só romance unificado.

A juíza, autora na sequência deste romance em cadeia, deve conhecer todas as interpretações passadas a fim de limitar o quadro das interpretações futuras, daquelas interpretações que poderão dar continuidade a essa história encadeada de um modo coerente. A dimensão de adequação é essencial para o romance em cadeia. Uma autora não pode adotar, por mais arrojada que seja, uma interpretação que acredita que nenhuma outra autora atribuiria ao texto que lhe foi entregue, pois seu desiderato, num primeiro momento, é escrever um capítulo que dê a melhor leitura possível da obra levando em consideração seu desenvolvimento integral. Durante a primeira etapa interpretativa, o juiz deve adequar sua decisão $(a)$ à história da prática social do direito vigente.

aos discursos reconstrutivos metafóricos, metonímicos e de negação; tais discursos devem operar em dois níveis: um nível de adequação seletiva da decisão dentro de uma tradição e um nível crítico-reflexivo de avaliação da tradição à luz dos ideais mais abstratos do constitucionalismo e de seu significado presente. Conferir ROSENFELD (2003b). Tal dinâmica tensionada de interpretação remete-nos aos princípios de adequação e de interpretação crítica segundo a justiça e a equidade no pensamento de Dworkin. 
(a) O ideal de integridade possui uma íntima conexão com a história institucional de uma dada comunidade política. Os direitos e deveres decorrentes das decisões coletivas da comunidade não emanam somente do conteúdo explícito dessas decisões passadas, mas também de um sistema de princípios necessários à sua justificativa. A prática atual pode ser organizada e justificada por princípios imbuídos no direito, integrantes de uma parte complexa da prática jurídica (DWORKIN, 1999, p. 274). A prática jurídica combina elementos que se voltam tanto para o passado quanto para o futuro: a prática jurídica contemporânea deve ser interpretada como uma política em processo de desenvolvimento. As proposições jurídicas verdadeiras são as que oferecem a melhor interpretação construtiva dos princípios que justificam a prática jurídica da comunidade (Ibid., p. 272).

A integridade é a chave para a melhor interpretação construtiva de nossas práticas jurídicas, do modo como nossas juízas decidem ${ }^{133}$ os casos difíceis nos tribunais. O princípio da integridade não tem necessariamente a última palavra na deliberação judicial, mas é o ponto de partida a partir do qual a juíza deve iniciar sua análise (Ibid., p. 263). Em uma segunda etapa, a juíza deve se expor a uma apreciação crítica do próprio material obtido no exame de adequação e justificação, tendo em vista a pertinência dessa tradição segundo uma compreensão atual da justiça e da equidade naquela comunidade política. Este é o momento em que o judiciário realiza uma interpretação reconstrutiva da história. Ainda que algumas obrigações associativas devam ser impostas prima facie, podem ser anuladas caso provoquem uma injustiça muito grave e profunda (Ibid., p. 247). A integridade exige que as normas públicas de uma comunidade expressem, na medida do possível, um sistema único e coerente de justiça e equidade na correta proporção. Por essa razão, uma instituição comprometida com a integridade se afastará da linha seguida pelas decisões anteriores sempre que for necessário para guardar a fidelidade aos princípios mais fundamentais do sistema (Ibid., p. 264).

Há dois princípios de integridade política: o princípio legislativo que pede à autoridade legislativa que tente tornar o conjunto de leis moralmente coerente, e o princípio jurisdicional que demanda que a lei seja vista como coerente tanto quanto possível (Ibid., p. 213). O princípio judiciário de integridade instrui as juízas a identificar direitos e deveres legais partindo do pressuposto de que foram todos criados por uma única autora - a comunidade personificada - e expressam uma concepção coerente de justiça e equidade (Ibid., p. 271).

\footnotetext{
${ }^{133}$ Dworkin admite que não seria possível reunir todas as normas e padrões estabelecidos pelo legislador sob um único e coerente sistema de princípios. No entanto, tal circunstância deve ser vista como um defeito, pois cabe às juízas engajar-se num esforço de remediar quaisquer incoerências de princípio (1999, p. 261).
} 
Os juízes que aceitam o ideal interpretativo da integridade decidem casos difíceis tentando encontrar, em algum conjunto coerente de princípios sobre os direitos e deveres das pessoas, a melhor interpretação da estrutura política e da doutrina jurídica de sua comunidade. (...) Os fatos brutos da história jurídica limitarão o papel que podem desempenhar, em suas decisões, as convicções pessoais de um juiz em questões de justiça (Ibid., p. 305).

A integridade motiva juízas e juízes a serem criativas e imaginativas no seu papel de identificar direitos e obrigações comunitárias. Mas, conforme observamos na seção anterior, estão limitadas a tomar decisões em matérias de princípio. E esses princípios de moral política obrigam as juízas a tomar decisões em certas direções. A teoria política em que se assenta o constitucionalismo reconhece a existência de direitos que funcionam como trunfos que devem ser observados nas decisões coletivas. E a integridade exige que o governo deve ter uma só voz ao se manifestar sobre a natureza desses direitos, sem negá-los a nenhuma pessoa, em momento algum, caso já tenham sido reconhecidos em casos anteriores semelhantes.

A integridade é o fundamento da exigência de coerência ao tratarmos de quais direitos e quais obrigações uma cidadã possui em uma determinada comunidade política. Quando indagarmos quais direitos temos, uma resposta parece axiomática: nenhuma cidadã tem menos ou mais direitos que aqueles que já foram reconhecidos a um outro grupo de cidadãs. O princípio abstrato da igualdade, fundamento de legitimidade das comunidades de princípios, demanda necessariamente um mandado de não discriminação. As políticas públicas de combate à homofobia nas escolas estão ligadas diretamente a demandas por não discriminação, a demandas pela extensão de direitos de igualdade a um grupo social que, por razões de preconceito, discriminação e da configuração das relações de poder social, tem tido suas possibilidades de igual consideração e respeito negadas. Políticas de combate à homofobia nas escolas estão embasadas no reconhecimento da igual dignidade das sexualidades oprimidas em uma democracia constitucional e expressam, em última análise, a promoção de um direito. Mas quais direitos, em termos mais específicos, envolvem esse tipo de políticas? Quais princípios estão articulados em sua justificação? Enfrentemos tal questionamento. 


\section{CAPÍtulo 3 - POLÍticas PÚblicas de COMBATE À hOMOFOBIA NAS ESCOLAS E A LEITURA DOS PRINCÍPIOS SOB O PARADIGMA DO ESTADO DEMOCRÁTICO DE DIREITO E SOB A IDENTIDADE CONSTITUCIONAL BRASILEIRA: os princípios da liberdade identitária e da igualdade como diferença}

O argumento defendido até agora em favor da constitucionalidade de políticas públicas de combate à homofobia nas escolas assevera que o combate à homofobia é uma questão de princípio. Com isso, queremos dizer que a persistência da homofobia tem impactos destrutivos sobre indivíduos identificados como não heterossexuais, impactos que atentam contra sua autoestima e respeitabilidade social, sua integridade física e moral, sua liberdade de expressão e, enfim, contra o tratamento isonômico que lhes é devido pela comunidade. Para chegarmos até essa conclusão, admitimos que os indivíduos, em um Estado democrático regido por uma constituição, possuem direitos à autoestima e à respeitabilidade social, à integridade física e moral, à liberdade de expressão e ao tratamento isonômico por parte da comunidade; e tais direitos portam dupla face: se de um lado impedem que a comunidade, mesmo em busca de seu bem-estar geral, aja de determinada maneira, de outro lado obrigam o Estado a agir (ou se omitir) observando certos princípios que promovem esses direitos.

Reconhecemos que a homofobia é uma prática social reiterada e abrangente que viola direitos e por isso deve ser combatida pelo Estado. Um dos ambientes estratégicos onde a homofobia se infiltra, se espalha e se reproduz é, como vimos, a escola. Se a escola pública é um espaço público mantido pelo Estado, deve ser regida pelos mesmos princípios constitucionais de justiça que obrigam o comportamento do Estado em qualquer instância: a escola é um locus onde os direitos devem ser levados a sério. E ninguém discordaria da assertiva de que as estudantes que frequentam as escolas públicas possuem certos direitos invioláveis, tais como o direito de receber uma formação educacional adequada, o direito de não ter sua integridade física, psíquica e moral violada, o direito de ser respeitadas com base em sua identidade particular (seja uma identidade de classe, de gênero, religiosa, racial ou étnica) etc. E, sobretudo, é incontestável que todas as crianças e as adolescentes brasileiras possuem um direito fundamental à educação. Em um sistema jurídico cujo mecanismo de produção normativa se baseia na tradição do civil law, ${ }^{134}$ o fato de haver dispositivos

\footnotetext{
${ }^{134} \mathrm{O}$ direito ocidental é divido em dois grandes sistemas ou tradições de produção normativa. O sistema de civil law, de tradição romano-germânica, retira direitos e obrigações sobretudo do direito escrito e legislado. $\mathrm{O}$ sistema de common law ou direito costumeiro, comum ou consuetudinário, de tradição anglo-saxã, desenvolveuse a partir das decisões dos tribunais, de modo que a maior parte dos direitos e das obrigações são retiradas dos precedentes judiciais. Entretanto, assistimos nos últimos tempos a uma influência mútua entre as duas tradições,
} 
normativos escritos que estatuem certos direitos e obrigações conta como o primeiro indício de reconhecimento de um direito.

Quando nos indagamos sobre quais direitos temos, em um sistema de civil law, certamente começamos nossa análise pela leitura do arcabouço normativo escrito e positivado em forma de Constituição, leis e demais atos normativos; em um segundo momento, observamos a interpretação desses dispositivos normativos pelos tribunais e as recomendações doutrinárias de peso a respeito dessa interpretação. Não almejamos defender um legalismo estrito em matéria de quais direitos e obrigações temos; muito pelo contrário, ao adotarmos a diferenciação básica entre regras e princípios de Dworkin, assumimos a possiblidade de uma obrigação ou de um direito jurídico serem concedidos através de princípios reconhecidos e construídos pela jurisprudência, uma vez que tais princípios já habitam a teoria política unificada que justifica nosso sistema político-jurídico. Apenas gostaríamos de lembrar que o fato de haver um texto de lei dispondo sobre determinada matéria deve ser considerado em primeiro plano quando da interpretação de uma norma jurídica relativa a essa matéria.

A Constituição da República Federativa do Brasil de 1988 (destarte, CF-88) reconhece o direito à educação como um direito social fundamental (art. $6^{\circ}$, caput) e dedica os artigos de 205 a 214 ao seu desenvolvimento. Entre outras coisas, reconhece o direito à educação a todas as pessoas e atribui a responsabilidade de seu provimento ao Estado, à família e a sociedade (art. 205), institui princípios básicos a serem observados pelo ensino (art. 206) e estabelece a obrigatoriedade e gratuidade da educação básica para crianças e adolescentes entre 4 e 17 anos de idade (art. 208, I). Todas as crianças e adolescentes entre os 4 e 17 anos possuem direito público subjetivo a ter acesso ao ensino gratuito de educação básica ${ }^{135}$ (art. 208, § $1^{\circ}$ ), o que significa que possuem o correspondente à categoria de direitos jurídicos (legal rights) na teoria dos direitos de Dworkin: qualquer cidadã brasileira dentro da faixa etária indicada pode cobrar judicialmente sua inserção em uma escola pública.

Embora saibamos que o direito à educação faz parte do sistema jurídico constitucional brasileiro, isso não nos diz, prima facie, que tipo de sistema educacional é esboçado pela

pela qual passa a haver uma grande valorização da jurisprudência nos países de civil law (assistimos a esse processo no Brasil recente, principalmente desde o alargamento da jurisdição constitucional proporcionado pelo sistema de controle de constitucionalidade desenhado na Constituição de 1988) e a ascensão da importância das leis escritas nos países de common law (BARROSO, 2009, p. 43).

135 A educação básica compreende a educação infantil (encarregada do desenvolvimento das crianças de até 6 anos de idade), o ensino fundamental (com duração de 9 anos, iniciando-se aos 6 anos de idade) e o ensino médio (com duração mínima de 3 anos). Conferir LDB (Lei no 9394/1996, arts. 22 e ss.). 
Constituição; tal clareza só poderá ser obtida se entendermos o direito à educação levando em consideração os demais princípios que o afetam. Reconhecemos que o direito à educação deve ser lido segundo a melhor compreensão dos princípios que estruturam o direito brasileiro tais como a compreensão adequada dos princípios da igualdade e da liberdade, princípios fundamentais em que se assentam os Estados constitucionais modernos -, os quais auxiliarão a conformar seu conteúdo normativo. A questão primordial que orientará este capítulo é: qual a melhor leitura do direito à educação tendo em vista o sistema constitucional brasileiro? A questão posterior, não menos importante, é: qual a relação entre o direito à educação e as políticas públicas de combate à homofobia nas escolas? Para respondermos à primeira questão, será esclarecedor tomarmos de empréstimo as noções de paradigma constitucional (Jürgen Habermas) e de identidade constitucional (Michel Rosenfeld).

Paradigma constitucional trata da maneira mais difundida de compreender os princípios abstratos do constitucionalismo dentro de contextos históricos temporais específicos. Ao decidir a respeito do conteúdo de princípios universais, os sujeitos afirmam uma compreensão implícita da sociedade como um todo com base em uma teoria social que serve de pano de fundo (HABERMAS, 2003b, pp. 124, 129; CARVALHO NETTO, 2002, p. 74). ${ }^{136}$ Um paradigma é deduzido, em primeira mão, da linha seguida pelas decisões jurisdicionais, expressando um modo como um princípio é lido e interpretado. Porém, o preenchimento de um paradigma resulta de uma disputa política mais ampla entre todos os sujeitos da comunidade do direito, não ficando à mercê das discussões elitistas entre especialistas (HABERMAS, 2003a, pp. 128-131). A noção de paradigma nos auxilia a responder à seguinte pergunta: qual é a compreensão atual do constitucionalismo sobre os princípios fundamentais da igualdade, da liberdade, da propriedade, da democracia, da separação entre público e privado? Paradigmas possuem um conteúdo universalista, se assentam na compreensão histórica das exigências universais atuais de um regime baseado nos ideais constitucionalistas.

Identidade constitucional trata da maneira mais difundida de compreender os princípios abstratos do constitucionalismo dentro de contextos históricos espaciais específicos. A identidade constitucional requer pensemos o desenvolvimento dos princípios

\footnotetext{
${ }^{136}$ Faz parte da condição humana a presença deste "pano de fundo de silêncio compartilhado", construído pelo entrelaçamento das práticas sociais das quais nós mesmos não nos apercebemos, e que moldam nosso modo de olhar sobre o mundo e de pensar sobre problemas (CARVALHO NETTO, 2002, p. 74).
} 
abstratos do constitucionalismo ${ }^{137}$ tendo em vista as tradições de uma cultura específica, incluindo-se sua tradição jurídica, sua história legislativa e jurisprudencial, a estrutura de seu sistema jurídico e o exercício comparativo com os limites decorrentes da ideia de constitucionalismo. O sujeito constitucional reinventa e reconstrói sua identidade através do discurso constitucional ${ }^{138}$ (ROSENFELD, 2003a, p. 40). A noção de identidade constitucional nos auxilia a responder à seguinte pergunta: de que forma os princípios da igualdade, da liberdade, da propriedade, da democracia, da separação entre público e privado devem ser lidos dentro da tradição do direito brasileiro? A principal fonte dessa resposta será a análise doutrinária da produção teórica local, as normas jurídicas positivadas no direito brasileiro relativas a esses princípios e a linha interpretativa que tem sido seguida pelos tribunais ao aplicar esses princípios.

No paradigma do Estado democrático de direito (CARVALHO NETTO, 2002, pp. 7780), há uma leitura atualizada dos princípios constitucionais segundo uma crítica reestruturante dos paradigmas antecedentes, do Estado liberal e do Estado social. ${ }^{139}$ No

\footnotetext{
137 Para acolher o pluralismo, uma identidade constitucional deve transcender os próprios limites concretos, factuais, de sua subjetividade e empreender reflexões tendo em vista princípios contrafactuais. A "pobreza inerente do real" faz com que a identidade do sujeito constitucional recorra ao ideal para formular uma concepção adequada, trafegando por uma verdadeira ponte entre o real e o ideal. A própria contradição entre o real e o ideal é capaz de fornecer um critério para a crítica das instituições vigentes (comparar com os conceitos de facticidade e validade em HABERMAS, 2003a). A reconstrução se beneficia do uso dessa imaginação contrafactual: “(...) parece recomendável submetermos a reconstrução, à medida que ela diz respeito à descoberta da identidade do sujeito constitucional, aos limites normativos inerentes ao constitucionalismo" (ROSENFELD, 2003a, p. 47). Nesse sentido os princípios que o constitucionalismo moderno requer, tais como a aceitação do Estado de direito e a proteção dos direitos fundamentais, alienam o sujeito constitucional ao o situarem diante da autoimagem do "outro" (Ibid., pp. 36-37).

${ }^{138} \mathrm{O}$ discurso constitucional é selecionado, descartado e organizado segundo o instrumental básico composto pela interação de elementos de negação, metafóricos e metonímicos. Sucintamente, negação trata do descarte de identidades anteriores incompatíveis com o sujeito constitucional, metáfora atua mediante um procedimento de destaque das semelhanças em detrimento das diferenças, enquanto metonímia realiza o papel contrário de contextualização das especificidades que devem sobressair na formatação da identidade constitucional. O processo metafórico tende à descontextualização, ao passo que o processo metonímico tende ao contrário. Enquanto a negação cumpre o papel primordial de renúncia dos conteúdos incompatíveis com a identidade constitucional, metáfora e metonímia compreendem discursos que irão preencher o vazio de identidade deixado, discursos que revelarão quais identidades e quais diferenças contarão na incorporação da identidade do sujeito constitucional ao final do processo reconstrutivo (ROSENFELD, 2003a, pp. 50, 68, 83).

${ }^{139} \mathrm{O}$ paradigma do Estado liberal restringe os direitos de liberdade e de igualdade à sua dimensão formal. Na transição para o paradigma do Estado social, há uma materialização tanto da liberdade - a liberdade concreta dos indivíduos passa a depender de programas positivos do Estado, o qual cria um séquito de clientes com autonomia reduzida, dependentes de suas prestações paternalistas - quanto da igualdade - a igualdade substantiva dos indivíduos também passa a depender da redistribuição de bens e recursos levada a cabo pelas prestações estatais. Em ambos os paradigmas há uma perda substancial da autonomia em sua dupla dimensão público-privada (HABERMAS, 2003b, pp. 140-146). Habermas introduz um novo paradigma, capaz de superar os déficits de autonomia dos predecessores, no qual é possível visar o nexo interno entre autonomia privada e autonomia pública. O paradigma procedimental procura principalmente proteger as condições do processo igualitário, mediante o patrocínio de "(...) cidadãos que participam de discursos políticos, articulando e fazendo valer interesses feridos, e colaboram na formação de critérios para o tratamento igualitário de casos iguais e para o tratamento diferenciado de casos diferentes" (Ibid., p. 183). Tal paradigma é ao mesmo tempo formal, pois
} 
Estado democrático de direito, a liberdade ganha uma dimensão positiva de autonomia pública, que passa a compor uma estrutura complexa do princípio da liberdade: a liberdade possui uma dupla dimensão negativa/ positiva, ${ }^{140}$ pois tanto compreende uma esfera de proteção dos indivíduos contra o Estado e a sociedade, dentro da qual o indivíduo mantém espaços de autonomia privada não coagida, quanto compreende uma esfera de possibilidades de participação dos indivíduos, tomados enquanto cidadãos, nas deliberações públicas do espaço político. Liberdade deixa de lado sua antiga compreensão unilateral de "egoísmo anterior à vida social" e passa a se complementada por uma dimensão pública. A igualdade é integrada por uma terceira dimensão - a dimensão da igualdade como diferença - que possibilita uma aplicação mais complexa do princípio da igualdade, para além de sua acepção formal (a igualdade de todas e todos perante a lei, o tratamento idêntico dos indivíduos) e de sua acepção material (a igualdade de fato de todos os indivíduos, a redistribuição equânime, na medida do possível, de bens materiais e recursos comunitários). Igualdade como diferença exige o tratamento desigual das diferentes, a consideração da diferença no processo interpretativo e aplicativo do direito. Ademais, as noções de público e privado - antes, esferas de ação social ou individual rigidamente apartadas - passam a ser entendidas como complementares e tensionadas entre si. Os antigos direitos privados de liberdade negativa ganham uma dimensão pública, à medida que uma pretensão à privacidade não pode servir de subterfúgio para imunizar certas discussões controversas do processo de deliberação pública. Os direitos de participação política ganham uma dimensão privada, pois a própria participação em uma esfera pública legítima ${ }^{141}$ requer sejam garantidos direitos privados básicos.

estabelece procedimentos pelos quais os próprios cidadãos formularão problemas e procurarão solucioná-los, e substancial, pois mantém um núcleo dogmático assentado na ideia de autonomia de sujeitos livres e iguais intersubjetivamente integrados (Ibid., p. 190). Ver também CARVALHO NETTO (2004a).

140 Ao longo da história do pensamento político, duas dicotomias relativas ao conceito de liberdade exprimem essa oposição: a oposição entre liberdade dos antigos e liberdade dos modernos, de Benjamin Constant, e a oposição entre liberdade positiva e liberdade negativa, de Isaiah Berlin. A liberdade positiva (dos antigos) proclama o ideal de autogoverno e preconiza que as pessoas devem desempenhar um papel no seu próprio governo coercitivo, em um governo democrático participativo. A liberdade negativa (dos modernos) afirma uma esfera de proteção individual dentro da qual há autoindependência para a tomada de decisões e a realização de atividades, preservada das decisões coletivas. DWORKIN (2011, p. 374) detecta um problema na noção de liberdade negativa, na medida em que a cooperação em uma comunidade política requer a relativização de algumas liberdades, desde que o governo aja no sentido de proteger a vida, a segurança e a liberdade dos outros. A liberdade negativa é de extrema relevância em uma democracia, mas não enquanto direito geral, mas somente na condição de proteção de pretensões individuais consignadas na ideia de direitos.

${ }^{141} \mathrm{O}$ espaço público da teoria habermasiana é descrito como uma caixa de ressonância onde encontram eco os problemas a serem elaborados pelo sistema político. Nesta medida, a esfera pública é uma espécie de sistema de alarmes sensíveis no âmbito de toda a sociedade, o qual, além de perceber e identificar os problemas, deve problematizá-los e tematizá-los de modo eficaz, a ponto de serem assumidos e elaborados pelo complexo parlamentar. "A esfera pública pode ser descrita como uma rede adequada para a comunicação de conteúdos, tomadas de posição e opiniões; nela os fluxos comunicacionais são filtrados e sintetizados, a ponto de se condensarem em opiniões públicas enfeixadas em temas específicos. Do mesmo modo que o mundo da vida 
A Constituição brasileira de 1988 acomoda tal compreensão paradigmática do direito. Identificamos um momento paradigmático na história constitucional pátria, quando, em virtude do julgamento da Ação Direta de Inconstitucionalidade nº 4277 (ADI 4277), em 2011, os ministros e as ministras do Supremo Tribunal Federal, órgão institucional guardião da Constituição (art. 102, caput-CF), competente para realizar o controle concentrado de constitucionalidade (art. 102, I, “a”) em prol da defesa dos direitos fundamentais das cidadãs brasileiras, reconheceram o direito à liberdade identitária e o direito à igualdade como diferença durante a fundamentação da constitucionalidade da união civil entre pessoas do mesmo sexo. De forma pioneira no âmbito da interpretação constitucional, foi expressamente consagrada a noção de que pessoas não heterossexuais têm liberdade de expressar sua identidade sexual e o correspondente direito de serem tratadas com igualdade de direitos a despeito de uma possível "diferença” atribuída às suas identidades.

Analisaremos a seguir o direito à liberdade identitária (seção 3.2) e o direito à igualdade como diferença ( seção 3.3) e seu status no paradigma do Estado democrático de direito e na identidade constitucional brasileira. Anteriormente, analisaremos a dicotomia público vs. privado (seção 3.1) e seus status no paradigma do Estado democrático de direito e na identidade constitucional brasileira, donde argumentaremos em favor da pertinência da discussão sobre o respeito das identidades sexuais no espaço público.

\subsection{Direito à educação entre o público e o privado}

Neste momento, debateremos a questão do combate à homofobia nas escolas sob o ponto de vista de teorias da justiça com enfoque nas contribuições feministas. Sugerimos que a dicotomia liberal entre esfera pública e esfera privada esconde a opressão sobre mulheres e crianças na esfera de privacidade da família. Por esse motivo, o argumento da privacidade das famílias para a formação de identidades é insustentável. As escolas, espaços estratégicos de construção de identidades, de reprodução e problematização de discursos opressores, devem ser encaradas como esferas públicas potencialmente emancipatórias, que forneçam às crianças condições para perseguir sua própria autoestima, escolher seus valores e engajar-se num

tomado globalmente, a esfera pública se reproduz através do agir comunicativo, implicando apenas o domínio de uma linguagem natural; ela está em sintonia com a compreensibilidade geral da prática comunicativa cotidiana. (...) A esfera pública constitui principalmente uma estrutura comunicacional do agir orientado pelo entendimento, a qual tem a ver com o espaço social gerado no agir comunicativo, não com as funções nem com os conteúdos da comunicação cotidiana" (HABERMAS, 2003b, p.92). 
processo autônomo de autodesenvolvimento identitário, protegidas das violências que usualmente constrangem - com lastimáveis consequências - os indivíduos a assumir compulsoriamente a identidade heteronormativa.

$\mathrm{Na}$ versão do liberalismo ${ }^{142}$ contemporâneo exemplarmente esboçada na teoria da justiça de John RAWLS (2000), o debate público deveria se restringir aos problemas da estrutura básica da sociedade, a respeito dos quais deveria haver um consenso sobreposto relativamente aos princípios de justiça; nessa perspectiva, as "doutrinas compreensivas razoáveis", tais como as matérias éticas primordiais para a construção de identidades, seriam toleradas, porém não tematizadas na deliberação pública. $\mathrm{O}$ feminismo foi incisivo ao denunciar as opressões perpetuadas no espaço privado, sobretudo no âmbito doméstico das famílias, em que haveria uma espécie de estado de exceção com suspensão dos direitos dos indivíduos em nome da manutenção da tradição hierárquica. Como se lê em Nancy FRASER (1990, p. 71), o discurso na esfera pública deve incluir questões "privadas": a demarcação entre questões públicas relativas ao bem comum e interesses privados frequentemente deslegitima interesses minoritários e oculta relações de poder e dominação que são invisibilizadas do espaço público sob a alegação de que pertencem a um âmbito não passível de problematização coletiva. Fraser argumenta que apenas as participantes por si mesmas podem definir quais são as questões que as concernem e precisam ser publicizadas mediante discursos de contestação. É o caso dos grupos sexuais minoritários: a opressão sobre eles exercida deve ocupar a agenda dos debates públicos, segundo a ideia de uma eticidade reflexiva, pois a única ética que se coaduna com o Estado democrático de direito é aquela que confere aos indivíduos meios e possibilidades de autorreflexão sobre seus interesses, tradição e costumes, para inclusive transformarem autonomamente suas identidades à luz de princípios de justiça e vivências mais inclusivas.

Desde suas fundações lockeanas (PATEMAN, 1989, p.121), o liberalismo político tem afirmado a diferenciação - a qual, de certa forma, o sustenta enquanto teoria e prática - entre esfera pública e esfera privada. À primeira pertenceria a dimensão política da vida pública, associada às ideias de igualdade de participação, liberdade, racionalidade, bem comum e

\footnotetext{
${ }^{142}$ É preciso ter cuidado ao caracterizar o liberalismo como um pensamento homogêneo, e mesmo afirmar que ele tenha se mantido incólume com relação às críticas sofridas, ainda mais porque renomadas feministas como Susan Okin e Jean Cohen se intitulam herdeiras do legado liberal. Escolhemos a teoria da justiça como equidade de Rawls como posição liberal a ser problematizada devido à sua enorme repercussão nas subsequentes teorizações sobre justiça e liberalismo político, e por ser considerada a mais alta expressão filosófica do liberalismo estadunidense (SANDEL, 2013). Não poderemos abordar pormenorizadamente o pensamento rawlsiano; para isso, reportamos à leitura de sua reformulação teórica em RAWLS (2000).
} 
Estado; à segunda pertenceria a dimensão doméstica da vida, corporificada na estrutura da família blindada pelo escudo da privacidade, associada às ideias de poder paternal, cuidado, afetividade, autointeresse e mercado (BIROLI, 2014, p.42). Em última análise, a separação entre público e privado contém uma homologia com a oposição cultura/ natureza, ${ }^{143}$ central para o racionalismo moderno. A defesa da privacidade do âmbito doméstico é um dos elementos justificadores da noção de direitos negativos de liberdade oponíveis contra a intervenção do Estado na esfera privada. Mesmo em virtude das já mencionadas lutas pela extensão dos princípios do Estado de direito ao regramento familiar, autores representativos do pensamento liberal contemporâneo, como o próprio Rawls, insistem na manutenção de associações privadas não vinculadas aos princípios públicos de justiça, pois - alegam - do contrário se restringiria a liberdade dos indivíduos de escolher seus próprios projetos de vida e portar suas concepções individuais acerca da vida digna (CITTADINO, 2009).

A família, que seria responsável pela transmissão intergeracional de valores justos, esconde, contudo, níveis de desigualdade que afetam negativamente os indivíduos que a constituem e reproduz injustiças que se espraiam na esfera pública. A visão idealizada da família como campo do amor, do afeto, da solidariedade, e não da justiça, obscurece as opressões, desigualdades e assimetrias internas ao arranjo familiar. Não por outra razão, parte notória das teorias feministas insistiu na ideia de que a instituição doméstica é um grande obstáculo para a realização de uma sociedade justa, pois a concepção de público/ privado, baseada em estereótipos excludentes de gênero, serviu para "afastar do debate público questões designadas como 'privadas' e, assim, blindar com relação às exigências de justiça as relações de poder assimétricas que governam a divisão do trabalho marcada por gênero e outros aspectos das 'relações íntimas' no interior do lar” (COHEN, 2012, p.167).

Uma das grandes incoerências da dicotomia é desconsiderar (ingenuamente?) que as disparidades no ambiente doméstico atravessam as mais diversas esferas da vida social e se

\footnotetext{
143 A dicotomia, em sua base, acaba por associar a mulher à natureza (emoção, amor, sujeição, particular enfim, o privado) e o homem à cultura (política, razão, justiça, poder, universal - enfim, o público). $\mathrm{O}$ patriarcalismo, apelando ao argumento da natureza, prescreve à mulher a função do cuidado com as crianças e um lugar doméstico subordinado, fora da vida pública. A capacidade natural e biológica das mulheres para gerar crianças seria uma aproximação da mulher à natureza, uma diferença sexual independente da história e da cultura, a qual justificaria um papel naturalmente subordinado. Os questionamentos feministas posteriores, principalmente através de uma perspectiva antropológica, demonstraram a artificialidade, historicidade e o caráter de construção cultural da valoração dada ao papel da mulher (PATEMAN, 1989, p.124). Certamente, existem especificidades biológicas entre os sexos feminino e masculino, mas tal diferença é valorada socialmente, não redundando, automaticamente, no subvalor do feminino, mas sim mostrando como os processos sociais acabaram por atribuir diferentes valores à masculinidade e à feminilidade, com a prevalência de expressões androcêntricas.
} 
propagam na esfera pública, diminuindo as chances de expressão e participação política das mulheres - devido à escassez de tempo, à instrução formal deficiente, ao silenciamento de suas preferências, à sobrecarga com os trabalhos domésticos, à dupla jornada de trabalho - e das crianças - vistas como ainda não moralmente autônomas e incapazes de vocalizar a maior parcela de seus próprios interesses fundamentais. Deste modo, há "um ciclo vicioso em que a menor capacidade de influência política leva à ausência de políticas que permitam romper com as dinâmicas que produzem a vulnerabilidade e a marginalização de determinados indivíduos (...)" (BIROLI, 2014, p.64). Ademais, o liberalismo aposta levianamente na aquisição da igualdade entre os gêneros mediante a progressiva garantia institucional de iguais direitos, sem considerar a existência da opressão informal desconectada da discriminação aberta, que está enraizada nas práticas institucionais, sociais e principalmente domésticas, de modo a produzir assimetrias concretas que comprometem a autonomia e a capacidade de exercício dos direitos formalmente promulgados por parte de mulheres e crianças.

A separação público/ privado é constitutiva de uma indissociável relação entre liberalismo, patriarcalismo e capitalismo. ${ }^{144}$ A família é desde sempre uma questão política de primeira ordem, o que se evidencia pela preocupação do Estado com a legislação sobre casamento e sexualidade, que mantém o status subordinado das mulheres. Não é possível entender a dicotomia sem levar em conta o fato de que ela é generificada ${ }^{145}$ e tem conotação claramente sexual (MOREIRA, 2010, p. 52), de que foi erigida sob a afirmação da superioridade masculina e da responsabilização feminina pela esfera doméstica (OKIN, 2008,

\footnotetext{
${ }^{144}$ A estrutura capitalista só pode ser compreendida se a figura do trabalhador é acompanhada da figura da mulher dona de casa que o apoia, cuida da casa e da educação dos filhos; e, mesmo que muitas vezes a mulher tenha uma atividade laboral extradoméstica remunerada, segue submetida a uma dupla jornada de trabalho (no emprego e em casa) e à percepção de menores salários e condições de trabalho mais precárias (PATEMAN, 1989, p.132). Além disso, como demonstrou Stuart Mill (apud PATEMAN, 1989, p.129), os princípios liberais não podem ser simplesmente universalizados de modo a conduzir as mulheres à esfera pública sem gerar um agudo problema na estrutura patriarcal da vida doméstica. Algo confirmado, também, pela prática feminista posterior, que demonstrou ser impossível uma completa igualdade da mulher na vida pública sem mudanças na esfera da privacidade. De outro lado, Nancy FRASER (1997) argumenta que a militância política feminista deve atuar em dois níveis: na demanda por políticas de reconhecimento e na demanda por políticas de redistribuição que atenuem os efeitos perversos do capitalismo.

${ }^{145}$ Para uma análise do modo como a reflexão de gênero inaugurou uma revisão na teoria liberal da justiça e da democracia, conferir OKIN (2008). A autora aduz que os papéis atribuídos ao feminino e ao masculino são diferenciações sexuais socialmente construídas, sendo que a categoria "gênero" refere-se à institucionalização social dessas diferenças (p. 306). Ainda expõe dois grupos de estudos sobre a explicação e desconstrução dos papéis de gênero: teorias psicologicamente focadas, que se debruçam no processo de individuação e experienciação da divisão de gênero por parte dos indivíduos e sua distribuição na divisão do trabalho familiar (pp. 316-317), e teorias com foco histórico e antropológico, que analisam o gênero como uma categoria social que tem sido universalmente disseminada nas sociedades humanas, mas sujeita a mudanças históricas (pp. 318$320)$.
} 
p.320). O liberalismo, ao menosprezar a natureza política da família, esvaziou o conteúdo social da democracia, restringindo seu alcance a um regime de governo, à política em sentido institucional, assertiva que vai de encontro ao pensamento político clássico, segundo o qual “'democracia' era o nome não meramente de uma forma de governo, mas de uma sociedade como um todo, e era habitualmente associada, por seus inimigos e críticos, bem como por seus simpatizantes, com o princípio social da igualdade” (PHILLIPS, 1997, p.158).

Ora, como o feminismo veio frisar, todas e todos devem ser conformadas pelos mesmos princípios de igual respeito e os lugares em que a democracia aparece devem ser multiplicados. "Uma sociedade inteiramente democrática seria uma na qual as pessoas consideram umas às outras em mútuo respeito e onde todas as relações, não importa quão pequeno ou íntimo o contexto, seriam permeadas pelo princípio de que cada pessoa tem igual peso" (Ibid., p.160). Neste sentido, é preciso conceber uma compreensão da privacidade adequada às exigências de justiça de uma sociedade democrática. Não obstante algumas feministas radicais tenham defendido a extinção total do valor da privacidade, seria tolice negar seu papel emancipatório na aquisição de importantes direitos individuais ${ }^{146}$ ao longo da história das sociedades liberais.

Nosso desiderato não é, em absoluto, rechaçar o argumento da privacidade e negar seu papel constitutivo na emancipação dos indivíduos e na legítima proteção da autonomia privada, mas sublinhar o uso indevido deste argumento quando ele impõe constrangimentos às pessoas, ao invés de liberá-las de constrangimentos. A garantia de um tipo de privacidade que permita um autodesenvolvimento pessoal não constrangido, protegido da vontade majoritária, dos valores tradicionais e da cultura dominante, é também um aspecto primordial de uma democracia liberal justa. Semelhante esforço já foi realizado por Jean COHEN (2012), cujo objetivo foi formular "um conceito de privado que possa servir como o correlato de uma noção diferenciada de público e - na forma de um direito à privacidade - proporcionar a proteção aos níveis de autonomia e pluralidade (...)" (p.169).

\footnotetext{
${ }^{146}$ Dentre esses direitos, muitos deles se referem diretamente a aquisições por parte das mulheres, tais como a proteção da integridade física com relação ao "estupro no casamento", a conquista da autonomia da mulher para escolher parceiros sexuais e afetivos etc. O direito ao aborto nos Estados Unidos, declarado constitucional pela Suprema Corte em 1973, no caso Roe v. Wade, foi justificado como uma exigência do direito à privacidade. Mais recentemente, o direito à privacidade é invocado para proteger a possiblidade da relação homoafetiva consentida entre adultos capazes e, inclusive, para legitimar perante o Estado o casamento entre pessoas do mesmo sexo. Neste sentido argumentaram os ministros do Supremo Tribunal Federal brasileiro no bojo da ADI 4277 e da ADPF 132, julgadas em conjunto no ano de 2011 (ver seção 3.4 infra).
} 
COHEN (Id., pp.171-174) inicia por registrar o paradoxo da privacidade: os direitos à privacidade, ao mesmo tempo em que pretendem proteger os indivíduos com relação ao poder do Estado, reforçam um modelo que oculta as hierarquias de gênero, ao invés de torná-las acessíveis ao escrutínio público. Nesse modelo, tudo que não é estatal é interpretado como esfera privada, natural e pré-política, na qual os indivíduos autônomos agiriam livremente e em condições de igualdade. No entanto, o privado constituído como lar resultou em vínculos de dependência e relações hierárquicas, posicionando "naturalmente" as mulheres e crianças como indivíduos dependentes com autonomia reduzida. Tal contradição ${ }^{147}$ reside na compreensão da privacidade como direito conferido à entidade familiar, instituição social protegida contra a intervenção pública, em oposição à privacidade dos próprios indivíduos que constituem essa entidade. A privacidade de grupos e a privacidade de seus indivíduos podem estar em conflito, quando aquela pode significar justamente o oposto para os indivíduos mais fragilizados. ${ }^{148}$ Desse modo, abstém-se de:

compreender a real importância de direitos que garantam autonomia decisória, inviolabilidade da personalidade e um sentimento de controle sobre as necessidades da própria identidade, a indivíduos socializados e solidários no domínio da "intimidade" - um complexo de direitos para o qual "privacidade" tornou-se um termo guarda-chuva (Ibid., p.172).

Numa correta compreensão do liberalismo, que leve em conta a pluralidade, a individualidade e a proteção à integridade física e moral, a privacidade pessoal é um bem para todos os sujeitos e merece ser intrinsecamente protegida em bases diferenciadas da proteção da família patriarcal como unidade, condensada na noção de privacidade de entidades.

\footnotetext{
147 Definimos a atribuição de privacidade às entidades como contraditória porque o liberalismo, por si próprio, enuncia o indivíduo como titular de direitos subjetivos, de modo que inserir uma noção holística de direitos coletivos seria adicionar um elemento estranho ao próprio sistema de direitos liberal. Essa é a tônica da defesa liberal à reação comunitarista de autores como Charles TAYLOR (1994), que propugnam pela construção da noção de direitos coletivos. Para tanto, conferir HABERMAS (2002, pp.229-268).

148 Referimo-nos principalmente às mulheres, às crianças e às idosas. A natureza da privacidade da esfera doméstica foi fortemente influenciada pela natureza patriarcal do liberalismo: segundo OKIN (2008, p.321), os direitos à privacidade elaborados desde Locke abarcam a relação dos chefes de família masculinos uns com os outros, e não deles para com seus subordinados - a mulher pertenceria ao domínio de privacidade do homem, assim como suas propriedades. "Na prática, essa noção da família como uma entidade singular que tem direitos contra o Estado, no que se refere à regulação de seus membros, reforçava a autoridade dos maridos sobre as esposas e dos pais sobre os filhos" (Ibid., p.323). Faz sentido a interrogação: “afinal, privacidade para quem?”. E ainda ancorada no pressuposto de que são os homens que gozam da privacidade familiar, OKIN (Id., p.327) arremata: “(...) as mulheres, tanto quanto os homens, precisam de privacidade para o desenvolvimento de relações íntimas com outras pessoas, para que tenham espaço para se afastarem de seus papéis temporariamente e para que tenham tempo de ficarem sozinhas, o que contribui para o desenvolvimento da mente e da criatividade".
} 
Uma possível solução para o dilema da privacidade seria compreender os direitos à privacidade como condição de exercício da interação comunicativa, nos moldes de como é esboçado o nexo interno entre autonomia privada e autonomia pública na teoria do discurso de HABERMAS (2003a). A autonomia decisória, condição para liberdade e igualdade de fala nos discursos públicos e do funcionamento do indivíduo enquanto agente moral, pressupõe processos comunicativos de desenvolvimento moral e autorreflexão ética que tornam possível o raciocínio prático. Todavia, não é possível definir de antemão a natureza essencialmente pública ou privada das questões controversas: é no interior dos próprios discursos públicos que se produz a determinação do que deve ficar ou não sob o manto protetor dos direitos de privacidade (COHEN, 2012, pp. 183,190), sob a condição de que apenas as afetadas por essa (des)proteção, por si mesmas, podem definir a inclusão ou exclusão de um tema na/ da agenda de debate público, na medida em que possam defender publicamente seus próprios interesses contra práticas potencialmente opressivas quando confinadas à privatização (FRASER, 1990).

Nesse sentido, os direitos individuais à privacidade instituem exigências de justiça no interior das próprias relações familiares (anteriormente imunizadas da justiça pública) e significam, ao final, a proteção da intimidade pessoal, moral, psíquica e corporal dos membros da família, quando as relações vierem a se distorcer em práticas de violência, humilhação e subjugação de membros vulneráveis - notadamente mulheres, crianças e idosas. “Apenas se um alto grau de igualdade for mantido na esfera doméstica da vida familiar esta estará sendo concebida como uma esfera privada consistente com a privacidade e a segurança socioeconômica das mulheres e crianças" (OKIN, 2008, p.314). Essa visão complexa e complementar entre as dimensões pública e privada influencia a mudança paradigmática do direito em direção ao paradigma do Estado democrático de direito. Neste, público e privado ocupam uma posição central de equipromordialidade: "direitos da criança e da mulher casada fizeram com que mesmo aquele espaço mais privado, o lar ou o leito conjugal, se transformasse em espaço público, onde os direitos são garantidos contra os pais ou o marido" (CARVALHO NETTO, 2002, p. 80).

Assistimos a frequentes e reiterados discursos de naturalização da heterossexualidade, ${ }^{149}$ como se a sexualidade fosse produto unicamente da "natureza

\footnotetext{
${ }^{149}$ Embora a partir principalmente do século XIX várias práticas sociais (LOURO, 2009, p.86) tenham sido arquitetadas para moldar sexualidades e encaixá-las em categorias estanques, a história de insubordinação das sexualidades oprimidas, seja através de práticas mobilizadas ou de atitudes individuais dispersas pelo cotidiano, nos ensina como as identidades sugeridas/ impostas são a todo momento questionadas, desafiadas, negadas e subvertidas pelos indivíduos de acordo com suas próprias formas de experienciação da individualidade. Esse
} 
humana". O corpo tem sido uma fonte material a partir da qual os comportamentos sociais possíveis são definidos, regulado pelos dispositivos de gênero e sexualidade que o utilizam para confinar o indivíduo nos limites anatômicos do sexualmente possível. Mas a sexualidade é mais do que o corpo, ela tem a ver com crenças, ideologias e imaginações que tomam como ponto de partida o corpo físico. Ela é uma construção social, uma invenção histórica, por meio da qual as possibilidades do corpo adquirem um sentido modelado em situações sociais concretas e contingentes (WEEKS, 2000; BUTLER, 2000). A sexualidade humana é objeto de intensa preocupação pública porque habita uma dimensão central da nossa existência: a liberdade sexual está intimamente ligada à dignidade humana. Com as revoluções sexuais eclodidas em meados do século XX, aprendemos que o sexo é também uma forma de prazer ligada à autossatisfação. "A vida sexual inclui a função de obtenção de prazer a partir de zonas do corpo - uma função que subsequentemente é posto ao serviço da reprodução. É frequente as duas funções não coincidirem completamente" (ALMEIDA, 2003, p. 7). Acreditar que a sexualidade é uma matéria privada é um delírio falacioso. Desde a emergência de uma sociedade de disciplinamento dos corpos, o comportamento sexual tem sido submetido a constantes intervenções institucionais: $:^{150}$

\begin{abstract}
A Igreja e o Estado têm mostrado um contínuo interesse no modo como nos comportamos ou como pensamos. Podemos observar, nos últimos dois séculos, a intervenção da medicina, da psicologia, do trabalho social, das escolas e outras instâncias, todas procurando nos dizer quais as formas apropriadas para regular nossas atividades corporais. (...) Mas, juntamente com isso, apareceram outras forças, acima de tudo o feminismo e os movimentos de reforma sexual de vários tipos, os quais têm resistido às diversas prescrições e definições. Os códigos e identidades sexuais que tomamos como dados, inevitáveis e "naturais", têm sido frequentemente forjados nesse complexo processo de definição e autodefinição, tornando a moderna sexualidade central para o modo como o poder atua na sociedade moderna (WEEKS, 2000, p. 43).
\end{abstract}

\footnotetext{
processo atinge seu ápice pelas sexualidades queer, aquelas que desafiam totalmente o binarismo inexorável que associa sexo biológico a gênero: é o caso dos e das transexuais, transgêneros e travestis. A teoria queer surge no campo da reelaboração pós-estruturalista da teoria da identidade, voltada para a reflexão sobre sexualidade. Essa teoria dramatiza as incoerências nas relações estáveis entre sexo cromossomático, gênero e desejo sexual, e confronta as políticas identitárias sexuais que se valiam de um essencialismo estratégico que acabava por excluir determinadas formas de sexualidade (ALMEIDA, 2003, pp. 18, 20). O vocábulo também pode descrever uma população que sustenta uma posição antinormativa quanto à sexualidade. Ver também CARRARA, SIMÕES (2007, p. 69).

${ }^{150}$ Jeffrey WEEKS (2000, pp. 50-52) esclarece que a sexualidade é "modelada na junção de duas preocupações principais: com a nossa subjetividade (quem e o que somos); com a sociedade (com a saúde, a prosperidade, o crescimento e o bem-estar da população como um todo). (...) Na medida em que a sociedade se tornou mais e mais preocupada com as vidas de seus membros - pelo bem da uniformidade moral, da prosperidade econômicas; da segurança nacional ou da higiene e da saúde - ela se tornou cada vez mais preocupada com o disciplinamento dos corpos e com as vidas sexuais dos indivíduos. Isso deu lugar a métodos intricados de administração e de gerenciamento; a um florescimento de ansiedades morais, médicas, higiênicas, legais; e a intervenções voltadas ao bem-estar ou ao escrutínio científico, todas planejadas para compreender o eu através da compreensão e da regulação do comportamento sexual".
} 
O argumento liberal da privacidade na formação de identidades sexuais nunca correspondeu à realidade das práticas sociais, pois, desde o começo das preocupações sociais com o sexo já consolidadas no início do século, a família não detém mais o monopólio da orientação da sexualidade de seus membros. Notemos que "o argumento de que a lei deveria ser cautelosa sobre a intervenção na vida privada, sobre a imposição de um único padrão moral, não levou à crença de que não fosse necessário nenhum controle da sexualidade" (WEEKS, 2000, p. 80). No Brasil, o Código Civil e a própria Constituição Federal trazem uma série de condicionamentos para as famílias, impondo-lhes, ao lado de uma proteção concedida, uma rede de obrigações. ${ }^{151}$

A imersão dos movimentos LGBT na arena política através de processos de ressignificação e resistência trouxe para o debate público questões antes confinadas ao privado, ${ }^{152}$ na medida em que a não heterossexualidade torna-se um elemento de desqualificação, subalternização e inferiorização de sujeitos, os quais vêm negada sua sexualidade como possibilidade erótica legítima e, por conseguinte, sua aceitação social e a proteção jurídica de suas identidades (IRINEU, 2014, p. 203). Por esses e outros motivos, a sexualidade não é apenas uma questão pessoal ou privada, mas também uma questão política (LOURO, 2000, p. 9).

É perceptível que a recusa de políticas de combate à homofobia nas escolas sob o pretexto do argumento da privacidade se ampara em uma noção equivocada que confere privacidade às entidades familiares, mas deixa pouco ou nada de privacidade para os indivíduos mais fragilizados da família - no caso, crianças e adolescentes em processo de formação de sua sexualidade - desenvolverem livremente suas identidades sem coações internas e externas. É com base na compreensão dos processos socialmente dinâmicos de

\footnotetext{
${ }^{151}$ Os artigos de 226 a 230 da Constituição Federal se ocupam de disciplinar alguns assuntos relativos à família e à responsabilidade de seus membros entre si, seja entre os cônjuges, seja entre pais, mães, filhos e filhas. Os artigos de 1511 a 1783 do Código Civil sustentam uma série de institutos jurídicos que disciplinam a família, tais como o casamento, o divórcio, a adoção, a tutela e curatela, a guarda dos filhos, o regime de bens dos cônjuges, o exercício do poder familiar, a prestação de alimentos etc., daí falar-se em um Direito de Família enquanto importante subdivisão do Direito Civil. Diante de tudo isso, soa ridícula a pretensão de que o Estado não venha se intrometer nas relações familiares. O Estado o faz, sempre o fez e o fará, e acerta toda vez que intercede em benefício dos membros mais vulneráveis das famílias.

${ }^{152}$ A reação contra as práticas não heterossexuais aumenta à medida que estas conquistam visibilidade social. De fato, as conquistas de direitos por grupos subordinados geram necessariamente reações violentas dos grupos dominantes, os quais temem perder seus privilégios e os antigos valores sagrados nos quais se ancoravam. Muito se diz no discurso popular que a homossexualidade "está aumentando", mas não se deve confundir o aumento de uma prática com a visibilidade que ela vem ganhando, bem como com o fomento de condições favoráveis (a diminuição dos estigmas sociais) para que essa prática seja materializada por pessoas desprendidas do peso da culpa moral. Conferir nesse sentido FRY, MacRAE (1985, pp. 31-32). As reações conservadoras às políticas públicas de combate à homofobia nas escolas (ver Capítulo 1, seção 1.4, supra) podem ser compreendidas nessa chave de leitura.
} 
formação das identidades individuais e preferências que destacamos tanto o valor da privacidade como recurso de proteção ao livre autodesenvolvimento da personalidade, quanto o valor da autonomia política para a vocalização de interesses na esfera pública que, do contrário, se silenciados sob o pretexto da privacidade familiar, poderiam resultar em opressão. Justamente a dialética entre privacidade e publicidade é que está por trás de políticas de reconhecimento e combate a preconceitos tais como o Projeto Escola Sem Homofobia.

\subsection{Direito à educação e o princípio da liberdade identitária}

Gostaríamos de passar pela questão da formação das identidades sexuais situada entre as esferas pública e privada. Conforme já afirmamos, o argumento da privacidade destacou a defesa da inércia do Estado com relação à formação das identidades sexuais das crianças, visto que identidades deveriam ser elaboradas no espaço familiar, privadamente protegido de interferências exógenas, sob a supervisão dos chefes de família. Nesse diapasão, uma proposta de inclusão do debate sobre identidades sexuais e gênero nas escolas - um espaço público por excelência e um ambiente de transmissão de processos de aprendizagem - seria inconstitucional ou no mínimo politicamente problemática, pois colocaria em xeque a autonomia das famílias para conduzir e administrar a educação sexual das próprias filhas. Tal argumento é insustentável por dois motivos: $a$ ) porque desconsidera que as identidades e preferências individuais são formadas também no espaço público, não apenas espontaneamente, mas por atribuição arbitrária de lugares sociais pela cultura dominante; e $b$ ) porque se baseia numa falsa compreensão da privacidade, ao conferir direitos à entidade familiar às custas de tolher a autonomia dos indivíduos, até mesmo através de violência (tanto é verdade que os sujeitos contestam a todo tempo esses lugares sociais impostos).

Assim como as preferências, ${ }^{153}$ as identidades dos sujeitos são arbitrariamente condicionadas por uma espécie de "mercado de possiblidades", no qual às vezes sequer é

\footnotetext{
153 A compreensão liberal-pluralista da democracia crê no caráter pré-político das preferências, como se o processo democrático fosse um mero mecanismo de agregação de preferências pré-fixadas e já estabilizadas em ambientes privados. Porém, as preferências individuais são modificadas à medida que são debatidas nos discursos públicos (SUNSTEIN, 2009), na medida em que se oferecem determinados catálogos de possibilidades. Essas preferências são em algum nível determinadas pelos hábitos e práticas sociais comunitárias, por informações e modos de vida veiculados na mídia (pela televisão, pelo cinema, pelas revistas), pela arte, pela literatura, pela linguagem, pelos contos e narrativas (incluindo as piadas e os mitos populares), pelas religiões, pelas opções dadas pelo Estado por meio de suas regulamentações e políticas públicas e, sobretudo, pelos
} 
possível escolher. A depender das condições de autodesenvolvimento de um indivíduo, ele pode simplesmente optar por subscrever determinado papel que lhe é social e culturalmente imposto (não sem o preço da angústia causada pela adaptação forçada) ou empreender uma luta para subverter esse papel (não sem o preço da marginalização sofrida pela transgressão comportamental). É nesse sentido a provocação de Jeffrey WEEKS (2000, p. 78) ao afirmar que as identidades são escolhidas: sentimentos e desejos sexuais não significam necessariamente aceitar uma posição social particular e um organizado senso de si, isto é, uma identidade no espaço político. "Escolher" uma identidade é uma opção altamente política. Mas aqui nos resta a possibilidade de problematizar a ideia de escolha: até que ponto essas identidades não são atribuídas socialmente, e assumi-las torna-se uma espécie de questão de sobrevivência política sob pena do ostracismo público?

Dificilmente uma assertiva que sustentasse que a identidade pessoal trata-se de uma espécie de revelação de uma verdade interior, descoberta pelo Eu como numa catarse, mereceria credibilidade no campo da teoria social. Contra a visão de que a identidade é uma essência "revelada" da imanência do sujeito em direção à sua persona social, à sua dimensão de ator performativo em sociedade, a visão construcionista da identidade aduz que as identidades são formadas e transformadas continuamente num processo de individuação mediado socialmente. Com efeito, as relações engendradas entre os sujeitos, entre o Eu e o Outro, são a infraestrutura dinâmica e cambiante em que se assentam as (auto)compreensões identitárias, por isso dizer-se que o elemento relacional é ínsito à genealogia do Eu.

Tanto defensoras quanto opositoras das políticas públicas de combate à homofobia nas escolas endossam, pelo menos tacitamente, um conceito construcionista de identidade. Quando especialistas, educadoras, militantes e representantes políticas como Jean Wyllys defendem essas políticas, o fazem por compartilhar a crença de que elas terão algum impacto desestabilizador e reconfigurador nas práticas sociais de exclusão e opressão e, logo, também compactuam de um entendimento dinâmico, e não estático, da cultura. Do mesmo modo, mas enxergando o potencial emancipatório dessas políticas com temores e receios, manifestantes conservadoras contrárias à discussão de sexualidade na educação, como Jair Bolsonaro, reiteram tais temores e receios na medida em que reconhecem o potencial (temerosamente) transformativo de projetos como o PESH no nível cultural e no nível identitário. Caso endossassem um conceito essencialista - segundo o qual haveria algum núcleo compacto

processos educacionais, sejam eles dentro de relações familiares, de relações com a sociedade em geral, ou dentro do ambiente escolar, na relação com colegas, professoras e professores. 
duro, inflexível, imutável, essencial da identidade de um indivíduo - , não teriam por que empreender semelhante saga combativa. O conhecimento de que as identidades (inclusive sexuais) estão em constante transformação, e são por isso produtos do dialético e instável processo social, parece subjacente a todo o debate, recusando-se qualquer atrelamento a pressupostos biológicos.

Não queremos nem devemos estabelecer aqui um quadro fechado e exaustivo descrevendo o processo pelo qual um indivíduo adquire uma determinada identidade social, seja ela heterossexual, homossexual, bissexual, cisgênero ou transgênero. Não há evidências suficientes de algum consenso quanto a isso no domínio quer das chamadas ciências naturais ${ }^{154}$ (da Biologia, da Genética, da Medicina, da Neurociência etc.), quer das chamadas ciências humanas ou da cultura ${ }^{155}$ (da Sociologia, da Psicologia, da Sexologia, da Antropologia etc.), e mesmo duvidamos que uma pesquisa nesse sentido seja necessária e eticamente defensável. Afinal, já afirmamos em outro momento que os estudos destinados a desvendar uma possível causa motriz da não-heterossexualidade têm como premissa que a heterossexualidade seja a sexualidade normal e normativa, logo estão impregnados de uma concepção ética bastante clara e pouco sustentável em solos unicamente "científicos" e bases epistemológicas idealmente neutras. O que pretendemos mostrar com a discussão sobre os processos sociais de formação de identidades é que não há modos de manifestação da sexualidade per se e em absoluto bons ou ruins, corretos ou incorretos, normais ou anormais, saudáveis ou patológicos, na medida em que há disputas intermináveis em torno da atribuição de valor e significado a essas mesmas identidades, as quais são resultado de relações de poder provisórias, precárias e por isso mutáveis, que se condensam em convenções que precisam ser interpretadas e desconstruídas pela escola na medida em que desfavorecem injustamente muitos sujeitos. Não há sexualidade natural e pré-discursiva: ${ }^{156}$ a sexualidade e seu significado emergem dentro de e por meio dos processos discursivos. A "assunção" da

\footnotetext{
${ }^{154}$ FRY e MacRAE (1985, pp. 60-79) retomam o percurso traçado pela ciência (da Medicina Legal, da Biologia, da Sexologia, da Psicanálise etc.) no afã de definir as causas da homossexualidade. “(...) A 'ciência médica' teve um papel político fundamental num nível mais sutil e profundo, pois ela é em grande parte responsável pelas noções que as classes médias urbanas têm a respeito da homossexualidade e da heterossexualidade com sendo dois campos 'naturalmente' distintos" (p. 78).

${ }^{155}$ Peter Fry e Edward MacRae (1985, p. 12) argumentam que as pessoas chamadas homossexuais não sofrem de uma condição, mas são levadas, por pressões sociais, a assumirem um papel social não ortodoxo a respeito do que é ser homem e do que é ser mulher na sociedade.

${ }^{156}$ A respeito da pretensão de naturalizar a sexualidade levantada por alguns discursos, Judith BUTLER (2000, p. 164) destaca a circularidade, a tendência tautológica desse argumento: "De fato, referir-se ingenuamente ou diretamente a um tal objeto extra-discursivo sempre exigirá a delimitação prévia do extra-discursivo. E, na medida em que o extra-discursivo é delimitado, ele é formado pelo próprio discurso do qual ele busca se libertar".
} 
heterossexualidade não é um processo espontâneo, mas constrangido desde o início, pois do contrário não se demandaria um aparelho regulatório de imposição da heterossexualidade, "um aparato que reitera a si mesmo através da imposição forçosa do 'sexo"” (BUTLER, 2000, p. 166). Mais interessante seria refletirmos sobre como e por que uma característica pessoal (um desejo erótico, uma inclinação afetiva, uma preferência sexual) passou a definir e demarcar identidades sociais. Mas antes de tudo, cabe-nos perscrutar se e por que, tendo em vista tantas críticas veementes, ainda precisamos do conceito de identidade.

\subsubsection{Excurso sobre o conceito de identidade}

Assistimos a uma proliferação de severas críticas ao conceito de identidade, mas, se nos atentarmos bem a elas, perceberemos que miram uma dentre pelo menos duas possíveis chaves de leitura, a saber, as teorias essencialistas. Não se tratam de críticas à identidade, antes de críticas antiessencialistas à identidade.

As descrições que Charles TAYLOR (1994) faz da identidade invocam um passado de história, ancestralidade, língua, costumes, tradições e narrativas comuns, que seria o ponto de interconexão entre pessoas que formariam um grupo cultural distinto dos demais na medida exata da idiossincrasia de seu passado. Por esse motivo os membros de determinado grupo cultural teriam hábitos moldados em certa medida pelo seu pertencimento grupal, e a defesa da coesão e da integridade do grupo redundaria necessariamente na proteção da identidade pessoal dos membros. (Nesse sentido a urgência de políticas de reconhecimento de direitos coletivos formuladas em nome da proteção e da promoção dos valores de um grupo “ameaçado de extinção"). ${ }^{157}$ Na leitura de TAYLOR (1994, p. 54), identidade significa “de

\footnotetext{
${ }^{157}$ Reconhecer a identidade na concepção de Taylor significa preservar o ambiente cultural no qual o sujeito está inserido e forma sua personalidade. Mas há algo de notavelmente diferente entre congelar uma cultura ameaçada (como se fosse um ecossistema) e entre favorecer as condições por meio das quais os indivíduos têm referência a um mundo da vida no qual sua identidade se forma, inclusive possibilitando a eles modificar esse mundo da vida com base em sua autonomia política e tendo resguardada sua autonomia privada. A proteção do ambiente cultural pode ser vislumbrada como uma questão de direitos humanos individuais, que exige "uma política do reconhecimento que proteja a integridade do indivíduo nos contextos da vida nos quais a sua identidade se forma" (HABERMAS, 1994, p.131, grifamos). Pela razão de negar a problemática relação entre indivíduo e coletividade, a perspectiva ecológica de preservação das culturas não pode prosperar - culturas não são ecossistemas, cujo proveito maior seria mantê-los intactos, mas entes mutáveis em constante transformação. Em um Estado constitucional democrático, garantir a integridade da cultura conflitaria com os direitos individuais de seus integrantes de escolherem se querem ou não se apropriar de sua herança cultural e preservá-la. "Nas sociedades multiculturais a coexistência de formas de vida com direitos iguais significa garantir a cada cidadão a oportunidade de crescer dentro do mundo de uma herança cultural, e garantir aos seus filhos crescerem nele sem sofrerem discriminação. Significa a oportunidade de confrontar esta e todas as outras culturas e perpetuá-las na sua forma mais convencional ou transformá-la; tal como a oportunidade de nos desviarmos dos seus comandos
} 
onde nós provimos; (...) o ambiente no qual nossos gostos, desejos, opiniões e aspirações fazem sentido". Leitura contrária é apresentada por Stuart HALL (2003, p. 109): as identidades teriam a ver “não tanto com as questões 'quem nós somos' ou 'de onde nós viemos', mas muito mais com as questões 'quem nós podermos nos tornar', 'como nós temos sido representados' e como essa representação afeta a forma com nós podemos representar a nós próprios”. Essa compreensão tem a vantagem de reconhecer a legitimidade da identidade pessoal contrastante com a romantizada metáfora da identidade grupal holística. Portar uma certa identidade significaria acima de tudo não ser ou dever ser desta ou daquela forma, mas poder negociar, a partir de certos pontos de partida, com aquilo que fomos, somos e queremos nos tornar.

O que Taylor não menciona é que os grupos não são somente culturais, mas principalmente sociais. Conceber um grupo como cultural implica em tratá-lo implicitamente como um dado da cultura, independente dos processos sociais que produzem cultura, perdendo-se a oportunidade de questionar a dimensão política das relações de poder que criam e mantêm determinadas tradições, usos e costumes ao invés de outras, as quais jazem ocultadas pela ficção fantasmagórica das práticas inerentes e autenticamente representativas desta ou daquela cultura. Como se houvesse uma verdadeira essência identitária, desta vez não por detrás de cada indivíduo, mas prestes a emergir do seio da coletividade ética. Seguindo a mesma lógica, uma concepção cultural e coletivista da identidade ignora o dinamismo da história e as iniciativas de membros dissidentes e minoritários que agem no intuito de transformar, recriar, reinterpretar, readaptar e reconfigurar as próprias tradições com base em sua autonomia pessoal.

Uma visão essencialista inevitavelmente amortiza o agonismo presente dentro dos próprios grupos, passa ao largo da natureza conflitiva, contestável e não pacífica da sociabilidade, e do fato de a opressão não acometer apenas os grupos subordinados como um todo, mas também membros do grupo individualmente considerados. Pode haver o exercício de opressões intra grupo ${ }^{158}$ pelas líderes contra as dissidentes e as minorias. Levando isso em

com indiferença ou romper com isso autocriticamente e depois viver acelerado por ter feito um corte consciente com a tradição, ou mesmo com a identidade dividida" (HABERMAS, 1994, p. 149). Conferir a crítica da perspectiva ecológica também em Steven C. ROCKEFELLER (1994, pp.110-112).

158 Mesmo os grupos sociais minoritários, oprimidos pelos grupos majoritários e relegados à posição de subcultura, podem desenvolver práticas opressivas dentro de seus limites. Promove-se a existência de uma minoria dentro da minoria. Discussões sobre a agência política homossexual têm criticado a ênfase dada a uma política identiária gay que excluía mulheres lésbicas, bissexuais, transexuais, travestis e transgêneros. Mesmo entre os homens, haveria uma realocação da lógica machista, pela ojeriza aos homossexuais passivos e efeminados por parte da comunidade gay. Conferir a esse respeito FRY, MacRAE (1985, pp. 26-28). “( ...) 
consideração, é mais acertada e prolífica a teorização de Iris YOUNG (1990, pp. 43-45) segundo a qual grupo social é um coletivo de pessoas diferenciado de pelo menos um outro no nível de formas culturais, práticas ou modo de vida. Seus membros têm afinidade devido ao porte de similares experiências, e em razão da experiência de pelo menos uma das formas de opressão ${ }^{159}$ desenvolvem um senso de identidade (ver FRY, MacRAE, 1985, p. 112). Os grupos constituem os indivíduos - o "eu" é um produto de interações linguísticas que são sempre contextualizadas em relações com outras pessoas, é um produto do processo social mas ao mesmo tempo são também constituídos pelos indivíduos, num processo de dupla via. Grupos não são substâncias com essências pré-definidas, cristalizadas e a-históricas, mas relações sociais dinamicamente situadas.

Uma política de reconhecimento nos moldes da teoria de Charles TAYLOR (1994), que trate identidades como essências fixas, imutáveis e impermeáveis, e os grupos sociais sob uma perspectiva ecológica - como se fossem ecossistemas já saturados que necessitam de proteção para impedir sua desintegração - falha em perceber o caráter socialmente (des)construtivo das identidades, as quais se formam em processos dialéticos engendrados nas relações de reconhecimento e nas suas consequências de negação ou assimilação de papéis sociais atribuídos. Uma adequada política de reconhecimento deve buscar instituir condições para o desenvolvimento autônomo e não constrangido das identidades, protegendo a privacidade, a individualidade e as chances de engajamento político em interações comunicativas sob condições de igual consideração e respeito.

\footnotetext{
'Atividade' significa poder em relação à 'passividade', que faz com que as relações de poder da vida cotidiana possam ser algumas vezes invertidas temporariamente no ato sexual de coito anal" (Ibid., p. 51).

${ }^{159}$ A opressão, categoria central do discurso dos movimentos emancipatórios dos anos 1960 e 1970, refere-se a fenômenos estruturais que imobilizam e diminuem um grupo. YOUNG (1990) distingue entre cinco faces da opressão, que podem ocorrer de forma associada uma à outra: exploração, marginalização, impotência (essas três primeiras ligadas às relações de poder que ocorrem em virtude da divisão social do trabalho), imperialismo cultural e violência. A presença de pelo menos uma dessas categorias seria suficiente para declarar um grupo como oprimido. No caso das sexualidades oprimidas, é sabido que gays, lésbicas, bissexuais, transexuais, travestis, transgêneros e demais designações - seria impossível enquadrar as múltiplas e plúrimas formas de sexualidade em categorias estanques e enumeráveis - sofrem pelo menos, necessariamente, de imperialismo cultural e violência. O imperialismo cultural envolve o paradoxo de experenciar a si mesmo como invisível ao mesmo tempo em que se é marcado como diferente e forçado à adequação a modos de vida exógenos que desafiam o próprio sentimento de autoidentificação do sujeito. A violência, de caráter sistemático, atinge membros de alguns grupos que temem ataques aleatórios e não provocados à sua integridade física ou moral, cujo motivo é senão prejudicar, humilhar e destruir suas pessoas; incluem-se nessa categoria a violência física e a violência simbólica, na forma de assédio, intimidação ou ridicularização. Sem dúvida, as sexualidades oprimidas sentem-se coagidas o tempo todo a adotar um padrão de vida que não é seu, a esconder e envergonharse da sua própria identidade, e a sofrer violência física ou simbólica, seja ela ostensiva ou velada. No caso das sexualidades queer (transgêneros, travestis, transexuais), que desafiam o binarismo associativo entre gênero e sexo biológico, é também frequente a experiência de marginalização, uma vez que muitas dessas pessoas sequer são aproveitadas pelo mercado de trabalho formal e acabam recorrendo a trabalhos subalternos e degradantes, como a prostituição.
} 
A mesma interrogação que fizemos anteriormente foi formulada por Stuart HALL (2003, p. 103): afinal, “quem precisa de identidade?”. Hall oferece ao menos duas respostas para essa pergunta, uma teórica e outra político-estratégica. A razão teórica indica que um conceito, embora inadequado em algum ponto, permanece útil e inevitável enquanto não for dialeticamente superado e substituído por outro mais produtivo (utilidade por inevitabilidade); assim, sem o uso da identidade como premissa do raciocínio alguns típicos problemas da política ou da sociedade sequer poderiam ser pensados de forma consistente. A noção de identidade adquire centralidade para compreender-se a agência dos movimentos sociais demandantes de direitos (HALL, 2003, p. 104). O questionamento de práticas sociais opressivas e a propositura de práticas emancipatórias alternativas é possibilitado somente quando militantes de determinada causa desenvolvem um senso de identidade coletiva próprio e utilizam-no no domínio político-estratégico.

Apenas com a construção positiva de uma identidade definida as vitimadas deixam de ser indivíduos e se tornam sujeitos ${ }^{160}$ históricos, alerta-nos RUIZ (2003, pp. 170-171). Desde o século XIX passaram a existir pessoas consideradas homossexuais, mas que isoladamente não tinham relevância política significativa. Somente a partir do momento em que homossexuais se mobilizaram em grupo e desenvolveram um senso de pertença a uma identidade coletiva ${ }^{161}$ é que as portas da política foram abertas para elas.

\footnotetext{
Para que surjam identidades distintivas, colocando-se contra as normas heterossexuais de nossa cultura, algo mais do que a atividade sexual ou mesmo desejo homossexual é necessário: a possibilidade de algum tipo de espaço social e apoio social ou rede que dê sentido às necessidades individuais. $\mathrm{O}$ crescimento, a partir do século XVIII em diante, dos espaços urbanos, tornando possível tanto a interação social quanto o anonimato, foi um fator crucial no desenvolvimento de uma subcultura homossexual (WEEKS, 2000, p. 70).
}

\footnotetext{
${ }^{160}$ Castor M. M. Bartolomé RUIZ (2003, p. 116) faz uma distinção entre indivíduo e sujeito, considerando sua correspondência com formas de identidade e seus respectivos impactos sociais. Os indivíduos seriam peças cooperantes na engrenagem do sistema social (Ruiz não deixa clara ou elabora uma teorização sobre "o sistema social", pelo menos neste momento), moldados em forma de subjetividades flexíveis e adestrados para se adaptar funcionalmente aos imperativos requeridos pelas instituições. Ele é reduzido a um "mero executor de tarefas, valores ou projetos pré-postos para ele, perdendo a dimensão da autonomia e tornando-se um indivíduo sujeitado. O que caracteriza a identidade do indivíduo moderno é o despojamento de sua dimensão de sujeito, ou seja, a cessão da autonomia de sua práxis criativa em instâncias heterônimas". E esse momento "quasetranscendental" em que o indivíduo, como que numa espécie de epifania, se torna um sujeito é o da construção e assimilação da autoconsciência de sujeito, da sua identidade - assim como acontece com a consciência de classe para a teoria marxista. "O indivíduo assume uma prática cooperante com as estruturas que o modelaram, ao passo que o sujeito cria suas próprias práticas, direcionadas segundo o universo simbólico por ele construído". O sujeito de Ruiz é aquele que alcançou o nível de discernimento reflexivo, para usar a linguagem de Lawrence Kohlberg, incorporada por Jürgen Habermas. Para uma análise da teoria da evolução social de Habermas, ver CARVALHO NETTO, SCOTTI (2011).

${ }^{161}$ Para uma sumarização do processo histórico através do qual se criou uma consciência da "identidade homossexual" nas sociedades ocidentais, conferir FRY, MacRAE (1985, pp. 80-100); FACCHINI, SIMÕES (2009, pp. 37-40).
} 
A agência política homossexual organizada explodiu no final da década de 1960, na Era Stonewall Celebration, ${ }^{162}$ nos Estados Unidos, e mais tardiamente no Brasil, com a criação do Grupo Somos em 1978, ${ }^{163}$ primeiro coletivo organizado de homossexuais (FACCHINI, SIMÕES, 2009, pp. 37 e ss.). Mesmo que a identidade venha a ser uma ficção, sua subjetivação traz significativas implicações discursivas, materiais e políticas.

Uma vez reconhecida a utilidade do conceito de identidade, cabe-nos investigar um que seja adequado às pretensões antiessencialistas, um conceito estratégico e posicional, para além da ideia de um núcleo estável que passa incólume pelas vicissitudes da história. Certamente, a identidade é alguma forma de identificação que cria a base da solidariedade e da fidelidade a um grupo a partir do reconhecimento de uma origem comum ou de características partilhadas. Identificar-se é um processo em aberto, uma construção nunca completa (HALL, 2003, pp. 106, 108), que se deslinda em oposição a um processo colateral homólogo sempre presente de negação. A identidade é o produto de constantes, contraditórias, complexas e provisórias identificações e negações do laço de pertencimento, de processos de inclusão e de exclusão. Para firmar uma identidade, o indivíduo assume pertencer a um grupo ("sou brasileiro", "sou negra", "sou mulher", "sou heterossexual”,...), o que significa, por conseguinte, que ele se exclui da identificação com todos os outros grupos ("não sou italiano, nem chinês, nem angolano etc.", "não sou branca", "não sou homem”, "não sou homossexual, nem bissexual, nem transexual etc.”,...).

Justamente devido a esses aspectos dialéticos - de identificação e negação, de inclusão e exclusão - esse conceito passa a portar um caráter relacional e referencial: nenhuma

162 Conferir FACCHINI, SIMÕES (2009, pp. 40-47) a respeito dos primórdios do ativismo europeu e do ativismo estadunidense, que se influenciaram mutuamente. "Mas os eventos de maio de 1968 em Paris e a incorporação de noções de liberdade sexual pela contracultura, juntamente com uma nova militância negra e feminista, formam o pano de fundo social para a criação da Frente de Libertação Gay (FLG), que começou nos Estados Unidos, mas logo se espalhou para grande parte da Europa Ocidental" (FRY, MacRAE, 1985, p. 96). Na noite de 28 de junho de 1969, a polícia nova-iorquina tentou interditar um bar chamado Stonewall Inn, no gueto de Christopher Street, frequentado principalmente pelas "tribos" homossexuais de Nova Iorque. Houve uma reação inesperada por parte dos frequentadores, que originou uma batalha entre homossexuais e policiais que duraria um fim de semana inteiro. Pouco tempo depois, esta data seria decretada o "Dia do Orgulho Gay" em memória à "Rebelião de Stonewall” (Ibid., pp. 96-97).

${ }^{163}$ Para uma excelente avaliação da evolução do movimento homossexual brasileiro do fim da década de 1970 rumo ao movimento LGBT, conferir FACCHINI, SIMÕES (2009, pp. 54-160). O periódico Lampião, cuja primeira edição saiu em abril de 1978, foi uma publicação pioneira na imprensa homossexual de então, ao abordar a homossexualidade de uma forma expressamente politizada e a partir de uma imagem contrária aos estigmais vigentes até aquele momento (pp. 84-85). O Grupo Somos apareceu publicamente em 1978, com uma carta endereçada ao Sindicato dos Jornalistas de São Paulo, protestando contra o tratamento preconceituoso dado pela grande imprensa à homossexualidade. Inicialmente, foi um grupo formado por 15 membros e tinha características de um espaço confessional, uma rede de apoio em que pessoas estigmatizadas dividiam suas angústias e compartilhavam suas experiências. Ao longo de 1979, o Somos cresce progressivamente, incorporando dezenas de outros membros, inclusive mulheres (pp. 96-98). 
identidade existe isoladamente, em absoluto, mas apenas como referência de contraste com relação a todas as outras. ${ }^{164}$ Vejamos a lógica: ser $X$ é não ser $Y$ e $Z$, quando $X, Y$ e $Z$ é o universo de possibilidades identitárias tendo por base um determinado marcador social. ${ }^{165}$

Raciocinar sobre essa dualidade em termos aritméticos torna evidente a convencionalidade da escolha de uma identidade normal e de uma identidade desviante, mas não explica o porquê de uma ser eleita às custas da(s) outra(s). Essa clareza é fornecida pela análise sociológica: o poder é o mecanismo social definidor de quais são as identidades hegemônicas e quais, a partir delas, são as diferenças. Como declara HALL (2003, p. 110), citando Laclau, "a constituição de uma identidade é um ato de poder" que exclui e estabelece poderosas hierarquias. Quem "detém o poder", 166 isto é, os grupos que detêm os dispositivos

${ }^{164}$ Desse modo, para ser Z necessariamente é preciso excluir a possibilidade de ser X ou Y; a lógica identitária é baseada na escolha, na perda e na autoexclusão. Se eu tomo como referência $Y$, os grupos $\mathrm{X}$ e $\mathrm{Z}$ serão considerados os diferentes: se eu sou igual àqueles que pertencem a $\mathrm{Y}$, logo sou diferente dos que pertencem a $\mathrm{X}$ e Z (Y é minha identidade e X e Z são a diferença). No entanto, se eu troco meu ponto de referência (para Z, digamos), outros grupos serão considerados os diferentes. Essa operação de lógica formal apenas pretende mostrar que a atribuição de identidade e de diferença, além de ser forçosamente relacional e referencial, é também convencional. A diferença é tão somente o "Outro", aquilo que é estranho ao "Eu" caso o Eu - e apenas caso o Eu - seja tomado como o padrão de referência. Muda-se a referência, muda-se a diferença. Identidade e diferença são grandezas inseparáveis mutuamente dependentes e determinantes (ver LOURO, 1997, p. 47; 2000, p. 25; 2009, p. 89). Identidade e diferença convivem em relações conflituosas: as identidades hegemônicas precisam das identidades subjugadas para sobreviver, pois só se definem ao rejeitar estas. Mas, ao mesmo tempo, são constantemente assombradas pelo poder desestabilizador, provocativo e perturbador do Outro.

165 Os marcadores sociais mais comumente evocados no discurso político em geral são sexo, gênero, sexualidade, raça e etnia. Seguindo a lógica dos binarismos, alguém não poderia ocupar concomitantemente duas categorias (X ou Y) diferentes: ou você é negro ou você é branco; do mesmo modo, ou você é homem ou você é mulher, ou você é heterossexual ou você é homossexual. Os binarismos são cegos à possibilidade do cruzamento de fronteiras e mais ainda de darem guarida à compreensão daquilo que está além das fronteiras. No campo da identidade de gênero se situam os principais desafios subversivos à dualidade identitária, a qual não consegue apreender de maneira satisfatória aquilo que vimos chamando de sexualidades queer: transgêneros, transexuais, travestis ou pessoas que simplesmente não se identificam com um ou outro gênero. De outro modo, a intersecionalidade é uma característica inevitável das identidades: uma pessoa não possui apenas uma identidade, mas várias e por vezes conflitantes identidades, à medida que vão se diversificando os grupos sociais. Por exemplo, uma pessoa pode ser oprimida devido a seu gênero e à sua orientação sexual (pelo fato de ser uma mulher lésbica), mas ao mesmo tempo ocupar uma posição privilegiada em relação a outras por motivos de raça e classe social (pelo fato de ser uma rica empresária branca). Por esse motivo, essa mesma pessoa pode militar no movimento feminista, ser associada de uma organização que defende a igualdade para as pessoas homossexuais, mas, ao mesmo tempo, ter interesse suficiente para votar em uma candidata a presidente da República cuja plataforma seja extinguir as cotas raciais e diminuir os direitos trabalhistas. Há de fato uma crise dos modelos universais de identidade - um posto que fora outrora ocupado pela identidade de classe social - em prol da fragmentação. Como observa RUIZ (2003, p. 147): “O constante processo de fragmentação das identidades, entretanto, foi se aprofundando até o extremo de que, na maioria dos casos, as pessoas coexistem no seu cotidiano com um conjunto plural de núcleos identitários. Isso provoca a vivência entrelaçada de várias identidades dentro de um mesmo indivíduo, fazendo com que cada um vá internalizando um modo de identidade flexível, maleável e com referentes frágeis”. A esse respeito, ver também LOURO (1997, pp. 51-54): Guacira Louro, reportando-se a Eve Sedgwick, traz um ilustrativo exemplo: uma mulher, ao usar o nome de casada, ao mesmo tempo evidencia sua subordinação como mulher e seu privilégio como heterossexual (p. 54).

166 Observemos que "deter o poder" é uma expressão imprecisa e forçosamente pouco verossímil. O poder não é um bem de que alguém se apropria definitivamente, mas uma estratégia exercida em uma determinada direção vetorial mas que encontra inerentemente múltiplos pontos de resistência. A relação entre os polos de uma relação de poder é marcada por constantes negociações, avanços, recuos, progressos, retrocessos, consentimentos, 
de controle social de uma dada sociedade, tais como os capitais financeiro, econômico, cultural, intelectual, retórico, discursivo, político, religioso etc., possuem também o privilégio de atribuir diferentes valores e significados aos grupos classificados; possuem a prerrogativa de representarem a si mesmos e de representar os outros (LOURO, 2000, p. 12). "A afirmação da identidade e a enunciação da diferença traduzem o desejo dos diferentes grupos sociais, assimetricamente situados, de garantir o acesso privilegiado aos bens sociais" (SILVA, 2003, p. 81), sejam esses bens materiais (patrimônio, renda, trabalho avaliado monetariamente...) ou simbólicos (respeitabilidade, honra, proteção da integridade moral, titularidade de direitos...). Por isso, atualmente, "o campo onde o conflito social se trava de modo mais acirrado é na luta pelo domínio do universo simbólico que constrói a identidade dos indivíduos" (RUIZ, 2003, p. 123). Isso talvez explique o empenho de grupos mobilizados no sentido de ocupar o espaço escolar, visto este como um espaço estratégico de produção e reconfiguração de identidades.

O poder, como vimos anteriormente, é exercido e perpetrado em e por meio de práticas discursivas produzidas em locais históricos e em instituições específicas, práticas que interpelam o sujeito a ocupar determinadas posições-de-sujeito às quais se atribui significados conforme sistemas de representação. ${ }^{167}$ Por exemplo, na cultura ocidental aquelas pessoas desviantes do padrão heteronormativo são comumente representadas de modo deturpado, preconceituoso, caricato, e essas representações designam aquilo que há de mais abjeto, subalterno e grotesco no conjunto de valores cultivados pela comunidade. Os sistemas de representação são atos linguísticos, são violências que se propagam pelo medium da linguagem à medida que vão sendo incessantemente repetidos nos discursos cotidianos.

Aplicando essas equações e inequações abstratas ao mundo do real tangível, isto é, às identidades sociais realmente existentes no nosso universo cultural, percebemos que as identidades estão organizadas segundo oposições binárias em que cada polo recebe uma carga positiva ou negativa, acarretando privilégios para um e estigmatização para o outro: homem/ mulher, branca/ negra, heterossexual/ homossexual, empregadora/ trabalhadora, pessoa autônoma/ portadora de necessidades especiais, cristã/ não cristã, cidadã nacional/ estrangeira,

revoltas e alianças. Isso não ignora o fato de que determinados grupos sociais são mais frequentemente subordinados e constituídos como "outridade", mas isso não os anula enquanto sujeitos potencialmente capazes de retomar as rédeas de sua autonomia. Conferir, nesse sentido, LOURO (1997, pp. 38-40).

167 Uma identidade pessoal estigmatizada é construída em um processo que envolve quatro etapas: a) sensibilização: o indivíduo se conscientiza de sua diferença em relação à norma; b) significação: o indivíduo passa a atribuir significados a essas diferenças dentro das possibilidades do mundo social; c) subculturização: o reconhecimento de si mesmo através do envolvimento com os outros "igualmente diferentes"; e d) estabilização: a completa aceitação de seus sentimentos e estilos de vida e eventualmente o envolvimento numa subcultura que dê apoio a pessoas com essas mesmas diferenças marcadas (WEEKS, 2000, p. 78). 
e assim por diante. Um desses polos é normalizado através de mecanismos sutis infiltrados nas práticas cotidianas e propagados pelas pedagogias socializantes, é revestido do status de normalidade, regra, cânone, padrão a partir do qual toda a "diferença" será julgada e inferiorizada e ao qual toda a "diferença" deverá se adaptar. Questionar a diferença como relações de poder significa problematizar, desconstruir e eventualmente ressignificar esses binarismos (SILVA, 2003, pp. 82-83), desnaturalizar essas convenções e quebrar as hegemonias. Essa é uma tarefa que tem sido empreendida vigorosamente pelas teorias contemporâneas de gênero e sexualidade (ver BUTLER, 2000; LOURO, 1997, 2000, 2009; WEEKS, 2000).

\subsubsection{Liberdade identitária e a moralidade convencional}

Uma compreensão liberal dos direitos exige a proteção da independência ética dos indivíduos. E a liberdade de formação, transformação e afirmação da própria identidade se compatibiliza com essa visão liberal, enquanto a ideia de imposição de convicções éticas de uma maioria sobre as minorias é uma visão antiliberal e inadmissível em um sistema regido por uma constituição que assegura direitos individuais de liberdade e direitos políticos de igual participação na composição da vontade pública. Em uma democracia constitucional, o Estado não pode limitar a independência ética de suas cidadãs, exceto para garantir outros direitos necessários à proteção da vida, da segurança e da liberdade de outrem, mesmo na hipótese em que haja maior popularidade de uma visão ética endossada pela maioria, mas controversa ao ponto de ser rechaçada por uma minoria ${ }^{168}$ (DWORKIN, 2011, p. 378). O argumento contrário afirma que a maioria tem direito de viver e de criar sua prole em uma cultura ética que julga conveniente, e isso incluiria, como instrumento de tal afirmação, uma legítima batalha pela propagação impositiva das normas sexuais cultivadas.

A difundida doutrina que podemos chamar de "moralismo convencional"169 é composta por dois argumentos: $a$ ) a sociedade tem um direito de proteger a si mesma e $b$ ) a sociedade tem direito de seguir suas próprias luzes. O argumento de que a sociedade tem um

\footnotetext{
${ }^{168}$ Sobre a relação entre independência ética e a ética da maioria: "No entanto, devemos insistir para que esse ambiente seja criado sob a égide da independência ética, que seja criado organicamente pelas decisões de milhões de pessoas com a liberdade de fazerem as suas próprias escolhas, e não por maiorias políticas que imponham as suas decisões a toda a gente" (DWORKIN, 2011, p. 380).

${ }^{169}$ Dworkin discute os argumentos do moralismo convencional com base em alegações feitas pelo lorde inglês Devlin, em 1958, durante a segunda Maccabaean Lecture na Academia Britânica, cujo pronunciamento foi intitulado "The Enforcement of Morals", em que se discutia a prática da homossexualidade (DWORKIN, 2007, pp. 371-398).
} 
"direito" de proteger sua própria existência inclui um pretenso direito da maioria de defender suas próprias convicções éticas e de defender seu ambiente social das transformações que almeja evitar. A sociedade seria livre para fazer valer tal direito quando o sentimento público de rejeição a um comportamento que ela julga imoral causar suficiente repulsa e indignação, mesmo que esse comportamento não tenha efeitos diretos sobre outros indivíduos em particular, e a homossexualidade poderia ser legitimamente coibida caso seja considerada abominável com tal intensidade. Então as legisladoras devem se manifestar sobre algumas questões morais especialmente estruturantes da sociedade - e os padrões e relações formados "privadamente" fazem parte dessa dimensão estruturante do ambiente em que nós e nossa prole vivemos - e decidir se as instituições porventura ameaçadas são suficientemente importantes para serem protegidas às custas da liberdade humana. A esse propósito, as legisladoras devem se orientar com base em um "consenso da maioria" [sic] (Ibid., pp. 374$382)$.

Dworkin replica que essa é uma compreensão incorreta do que significa desaprovar com base em princípios de moralidade pública; considera esse um "conceito discriminatório de uma posição moral". Motivações de preconceito não são critérios pertinentes para demarcar as posições morais. Nossa cultura democrática reconhece como princípio que um homem ou uma mulher não podem ser consideradas moralmente inferiores com base em características que não possam evitar ter. Não seria coerente declarar a inferioridade moral de homossexuais quando se reconhece que é errado declarar a inferioridade moral de minorias raciais, étnicas, religiosas ou linguísticas; caso isso ocorresse, haveria um grave problema de incoerência. ${ }^{170}$ As razões de alguém para repudiar o comportamento de outrem devem pressupor coerência com as teorias morais que essas razões pressupõem. Assim conclui DWORKIN (Id., p. 393):

Sendo assim, os princípios democráticos que seguimos não exigem a aplicação do
consenso, pois a crença de que preconceitos, aversões pessoais e racionalizações não
justificam a restrição da liberdade alheia ocupa, ela mesma, uma posição
fundamental e crítica em nossa moral popular. Por outro lado, nem a comunidade
como um todo teria o direito de orientar-se por suas próprias luzes, porque a

${ }^{170}$ Confira-se a passagem de Dworkin sobre a incoerência de se tratar a liberdade religiosa como prioritária, mas ao mesmo tempo negar aos outros o direito à sua própria liberdade de consciência e de crença: "Não se pode declarar um direito à liberdade religiosa e, depois, rejeitar os direitos à liberdade de escolha nessas outras questões essenciais sem revelar uma contradição clara. Se insistirmos para que nenhuma religião específica seja tratada como especial na política, não podemos tratar a própria religião como especial na política, como se fosse mais central para a dignidade do que a identificação sexual, por exemplo. Assim, não devemos tratar a religião como sui generis. É apenas uma consequência do direito mais geral à independência ética em questões essenciais" (Ibid., p. 385). 
comunidade não estende esse privilégio aos que agem com base em preconceito, racionalização ou aversão pessoal.

A identidade constitucional não se confunde com as demais identidades préconstitucionais (identidades éticas, religiosas, culturais, étnicas), mas incorpora seletivamente algumas das tradições pré-constitucionais que sejam com ela compatíveis através de um processo de reconstrução voltado para o equilíbrio entre a rejeição e a assimilação da tradição, entre o pluralismo inerente ao constitucionalismo contemporâneo e a tradição, entre a herança dos limites estruturais inerentes ao constitucionalismo e a herança sociocultural da comunidade política (ROSENFELD, 2003a, pp. 21-27, 97). A Constituição filtra, através da articulação entre discursos metafóricos e metonímicos, as tradições preexistentes e incorpora aquelas que não ameaçam sua integridade: ${ }^{171}$ nesse sentido a Constituição é uma nova tradição, ou melhor, é $a$ "contratradição" que deve ser compartilhada pela comunidade política pluralista.

O argumento conservador discutido no Capítulo 1, de que as famílias que cultivam valores tradicionais têm o direito moral de defender a tradição de uma possível proliferação de comportamentos homossexuais a partir da incorporação da não heterossexualidade na identidade de crianças e adolescentes, não possui qualquer correspondência com uma noção de moral ou de ética compatível com nossa cultural política, com nossa identidade constitucional ou com nossas noções sobre democracia. Uma identidade constitucional pluralista não admite esse tipo de tradição preexistente de tal modo incompatível com os princípios do constitucionalismo; a única tradição que deve ser compartilhada em caráter obrigatório pela comunidade é a própria tradição das liberdades democráticas e dos direitos de igualdade, é o retorno a um recente passado de orgulho por nossa cambiante história republicana, tal como o conceito habermasiano de patriotismo constitucional. A proteção da liberdade identitária integra a independência ética do indivíduo que não pode ser vilipendiada pela comunidade a não ser em eventuais situações de proteção dos direitos de outro indivíduo. Não é o caso da proteção das identidades sexuais. Reconhecemos que as identidades sexuais são formadas em processos dinâmicos, transformativos e complexos, e em longo prazo a alteração das identidades pessoais poderá ter (e terá) um impacto sobre o modo como

${ }^{171}$ ROSENFELD (2003a, p. 106) destaca três critérios para a incorporação da tradição preexistente pela nova (contra)tradição constitucional: $a$ ) é preciso que uma tradição não ameace a contratradição constitucional; $b$ ) é preciso que essa tradição não enfraqueça os limites do constitucionalismo e $c$ ) ela deve ser suscetível de ser aceita como válida por uma expressiva maioria no interior da comunidade política. 
passaremos a viver nossas (novas) tradições. Agentes conservadores que se opõem à discussão de gênero e sexualidade nas escolas, como o deputado Jair Bolsonaro, sabem muito bem disso e por isso temem o poder desestabilizador das políticas públicas voltadas à tematização do gênero e da sexualidade. Não obstante, nada podem fazer para impedi-las sem que rompam o compromisso suposto de que todas agimos orientadas por um sistema coerente de princípios de justiça que obtém legitimidade ao tratar a todas e a todos com igual consideração e igual respeito.

\subsection{Direito à educação e o princípio da igualdade como diferença}

O liberalismo surgiu no cenário da reflexão político-filosófica contestando as hierarquias herdadas pela tradição nobiliárquica, dinástica e estratificada. Para isso precisou reivindicar o igual valor de cada indivíduo enquanto unidade moral, titular de direitos subjetivos exercidos contra o Estado e as coletividades éticas. Tal virada paradigmática redundou no princípio da igualdade formal de todos perante a lei, conforme a crença de que leis gerais e abstratas que tratassem os indivíduos de maneira isonômica seriam suficientes para concretizar o ideal da igualdade política de uma sociedade "pós-tradicional". Sobretudo devido às experiências de luta por igualdade que atravessaram os séculos XIX e XX, capitaneadas por movimentos emancipatórios de operários lutando por melhores condições de trabalho e de sujeitos múltiplos lutando pela extensão dos direitos liberais de igualdade às mulheres, negros e negras, povos aborígines e minorias étnicas, homossexuais etc., construiuse passo a passo uma consciência de que a igualdade formal e o enfoque individualístico produziam injustiças concretas. ${ }^{172}$ A teoria liberal dominante não ficou imune a uma miríade de críticas provindas do socialismo, do comunismo, do republicanismo, do feminismo, do multiculturalismo e do comunitarismo (MIGUEL, 2005).

Tal consciência acompanha o entendimento de que uma mesma lei afeta de formas diferentes homens e mulheres, brancas e negras, heterossexuais e homossexuais, jovens e idosas, pessoas autônomas e deficientes físicas, proprietárias e trabalhadoras, e assim por diante. Nesse contexto, DENNINGER (2003) sugere que o princípio da diversidade viria a substituir o princípio da igualdade de inspiração liberal dentro de um novo paradigma

\footnotetext{
${ }^{172}$ Ver HABERMAS (2003b, pp. 132-147), a respeito do movimento de materialização do direito privado desde principalmente o início do século XX.
} 
constitucional. ${ }^{173}$ A igualdade de tratamento pode produzir distorções na igualdade de resultados, ainda mais quando pessoas encontram-se em situações de desvantagem umas com relação às outras, ocasionadas por relações de dominação, subordinação e opressão que não acometem apenas os indivíduos isoladamente, mas, em caráter sistemático, dirigem-se a grupos que portam necessidades especiais geradas frequentemente por processos sociais de desvalorização de sua forma de vida e de seu status enquanto membro da comunidade. A correção dos erros de compreensão e aplicação da igualdade poderá ser minimizada se nos atentarmos para a dialética entre igualdade de tratamento e igualdade de resultados; aliás, é esse entendimento que está por trás das recentes políticas de ações afirmativas para a equiparação das condições de acesso a bens, oportunidades e respeitabilidade de grupos em desvantagem.

A crítica da igualdade formal vai além da introdução do princípio da igualdade material ou substantiva, ligado à premissa socialista de equalização da situação fática dos indivíduos através da distribuição equânime de bens materiais. O princípio da igualdade como diferença (ROSENFELD, 2003a, p. 88) ${ }^{174}$ emerge nesse cenário em que a realização da justiça não se traduz necessariamente na remoção dos elementos de diferenciação, mas também na igual valorização de determinadas formas de vida e cosmovisões abrangentes que querem se reafirmar como diferentes. A questão primordial passa a ser quais diferenças podem ou não resultar na concessão de direitos iguais. "Não é a ausência ou a eliminação da diferença, mas sim o reconhecimento da diferença e a decisão de ignorá-la ou de levá-la em consideração" (SCOTT, 2005, p. 15).

Disso segue que o pertencimento de indivíduos a determinados grupos sociais pode situá-los em situações de inferioridade e estigmatização; a compreensão meramente formal da

173 DENNINGER (2003) chega a sugerir o abandono do paradigma constitucionalista derivado da Revolução Francesa - inspirado pela tríade liberdade, igualdade e fraternidade - em prol da adoção de um novo paradigma baseado nos ideais de segurança, diversidade e solidariedade, o qual forneceria uma compreensão mais exata ao menos da prática constitucional alemã contemporânea. Embora seja extremamente instigante sua reflexão, HABERMAS (apud ROSENFELD, 2003b) mostra como os antigos princípios de liberdade e igualdade não teriam sido suplantados, mas sim ressignificados segundo a ideia de paradigmas, que correspondem a novas interpretações dos mesmos princípios à luz das novas experiências históricas do processo constitucional.

174 ROSENFELD (2003a, pp. 88-90) apresenta a seguinte reconstrução, em três estágios, do princípio da igualdade ao longo da história constitucional estadunidense: o primeiro estágio é marcado por uma forte correlação entre desigualdade e diferenças, o segundo estágio é marcado pela correlação entre identidade e igualdade e o terceiro estágio, da igualdade como diferença, leva em conta as diferenças sem utilizá-las para justificar a dominação ou a subordinação. O terceiro estágio segue o ideal de "dar a cada um segundo suas distintas necessidades". A igualdade como diferença se apoia na mútua influência entre identidade metafórica e diferença metonímica, no equilíbrio entre o polo da identidade e o polo da diferença, avaliando quais diferenças devem ter consequências jurídicas e quais não, tomando-se sempre o cuidado de evitar uma identidade por demais restritiva ou uma diferença insuficientemente delimitada. 
igualdade é cega a esse problema, e precisa ser articulada numa relação complexa com uma compreensão da igualdade enquanto diferença. São necessárias políticas públicas que considerem desigualmente as sexualidades oprimidas como grupos sociais e se dirijam especificamente a elas para minimizar a situação de inferioridade à qual se sujeitam, com a finalidade de instituir uma real igualdade de resultados, qual seja, o gozo de estima e respeito por parte dos indivíduos que as constituem. Indivíduos e grupos também são conceitos interdependentes que estão em constante tensão. Enquanto houver preconceito e discriminação, os indivíduos precisam ser avaliados como inseridos em determinado grupo que lhes confere um status social, cultural ou econômico que pode lhes inferiorizar (Ibid., pp. 13-14). A atribuição de características estigmatizantes a um grupo e a marcação desse grupo como minoria funcionam frequentemente como um álibi para o tratamento desigual de seus membros. E a identidade de grupo funciona como um paradoxo: os movimentos de protesto por igualdade ao mesmo tempo reafirmam e repudiam as diferenças que os excluem do status da igualdade (Ibid., p. 20), ou reiteram que essas diferenças não poderiam alojá-los numa condição de desigualdade.

\begin{abstract}
As identidades de grupo são um aspecto inevitável da vida social e da vida política, e as duas são interconectadas porque as diferenças de grupo se tornam visíveis, salientes e problemáticas em contextos políticos específicos. É nesses momentos quando exclusões são legitimadas por diferenças de grupo, quando hierarquias econômicas e sociais favorecem certos grupos em detrimento de outros, quando um conjunto de características biológicas ou religiosas ou étnicas ou culturais é valorizado em relação a outros - que a tensão entre indivíduos e grupos emerge. Indivíduos para os quais as identidades de grupo eram simplesmente dimensões de uma individualidade multifacetada descobrem-se totalmente determinados por um único elemento: a identidade religiosa, étnica, racial ou de gênero (Ibid., p.18).
\end{abstract}

A luta por reconhecimento da diferença de grupos que se mobilizam em torno da nacionalidade, da etnia, do gênero e da sexualidade teria se convertido no paradigma político pós-socialista do século XX (FRASER, 1997). A justiça inclui não somente distribuição, como também as "condições institucionais necessárias para o desenvolvimento e o exercício das capacidades individuais e comunicação e cooperação coletivas" (YOUNG, 1990, p.39). Também envolve questões que não podem ser facilmente assimiladas à lógica da distribuição: procedimentos decisórios (decisionmaking procedures), divisão do trabalho e da cultura. Por seu turno, Axel HONNETH (2001, pp. 43-44) identifica uma crescente ideia nas sociaisdemocracias, segundo a qual a eliminação da desigualdade passa por evitar a degradação e o desrespeito através da criação de condições para o reconhecimento da dignidade de todos os 
indivíduos. O ponto de partida para definir o conteúdo do conceito de reconhecimento ${ }^{175}$ é concebido negativamente mediante a categoria da ofensa moral: toda ofensa moral encerra em alguma dimensão um reconhecimento negado ou recusado, e finalmente a desconsideração de aspectos centrais da personalidade de um sujeito (Ibid., p. 48).

Em suma, o liberalismo dominante baseia-se na falsa premissa de que o Estado deve ser imparcial e neutro com relação a formas de vida e valores defendidos pelos indivíduos. O ideal de imparcialidade apenas esconde a seletividade do Estado, ${ }^{176}$ o fato de que determinados grupos têm acesso privilegiado a bens, recursos e valores que orientarão a ação do Estado sob a aparência legitimatória do bem comum e do agir orientado ao interesse geral (YOUNG, 2012). Os grupos conservadores, sobretudo religiosos, têm tido acesso privilegiado aos órgãos estatais decisórios no Brasil recente e silenciado a perspectiva social daquelas pessoas que elegeram como suas inimigas (num verdadeiro sentido antagonístico, e não agonístico): ${ }^{177}$ aquelas desviantes do padrão da heterossexualidade, do modelo de "família tradicional”. Inclusive é lícito atribuir à sua atuação massiva a retirada do Projeto Escola Sem Homofobia de circulação. Em seu ataque à aquisição de direitos por parte das LGBT, frequentemente invocam uma tradição excludente revestida de um global conceito de bem comum, moralidade coletiva ou bons costumes, que fere os valores da laicidade do Estado e do pluralismo de múltiplas formas de vida legitimamente existentes.

Não obstante, muitas das críticas dirigidas contra o liberalismo político são errôneas em certa medida, pois, ao atacar a estrutura liberal como se fosse um todo holístico, falham em perceber a distinção analítica primordial entre conceitos e concepções. Ao passo que os conceitos invocam ideias morais abrangentes, as concepções são teorias particulares sistematizadas elaboradas a respeito do que vem a ser a melhor interpretação dessas ideias morais (DWORKIN, 2007, pp. 211-213). Com efeito, o conceito do liberalismo que julgamos

\footnotetext{
${ }^{175}$ HONNETH (2001, pp. 49-50) distingue entre três padrões intersubjetivos de reconhecimento para uma vida bem sucedida - isto é, entre três formas pelas quais uma pessoa pode ter seu reconhecimento negado, o âmbito de sua vida afetado e o tipo de sofrimento acarretado em decorrência. São eles: a) amor - ocorre nas redes de relações primárias familiares e de amizade. É desrespeitado através de maus tratos e violação da integridade física. Sua violação prejudica a autoconfiança; b) reconhecimento jurídico - significa o reconhecimento da pessoa enquanto igual membro em uma comunidade do direito, portador de iguais direitos. É desrespeitado através da privação de direitos e negação da igualdade. Sua violação prejudica o autorrespeito; c) solidariedade consiste no reconhecimento do valor das contribuições da pessoa para seu meio social. É desrespeitada através da depreciação do valor social. Sua violação prejudica a autoestima.

176 Sobre o modo como as decisões do Estado produzem identidades sociais e reforçam a ideologia heteronormatizante, ver MOREIRA (2010).

${ }^{177}$ Agonismo e antagonismo se diferenciam na medida em que este se refere à relação entre amigos e inimigos, enquanto aquele se refere à relação entre adversários, cujas ideias podem ser combatidas com vigor, mas jamais se questionando o direito de defendê-las. Na compreensão agonística, o adversário tem legítima existência e deve ser tolerado (MOUFFE, 1999, p.16).
} 
adequado defender - e aqui tomamos este princípio com uma força axiomática, uma vez que toda doutrina política se vale da escolha e conseguinte defesa de determinado valores baseia-se no princípio que estipula que "os indivíduos têm direito à igual consideração e ao igual respeito no projeto e na administração das instituições políticas que os governam" (Ibid., p. 279). Tal princípio traz para o âmago do liberalismo a virtude da igualdade, predecessora até mesmo da ideia de liberdade.

Questões contra as quais as críticas do liberalismo usualmente se posicionam - e também nos posicionamos enquanto críticos de algumas delas - sobre a relação entre as esferas pública e privada e entre imparcialidade e reconhecimento, a arquitetura institucional que o liberalismo requer, as mais eficazes políticas públicas para promover a igualdade, a relação mais conciliatória entre liberdade e igualdade, as reais exigências do direito à igualdade em casos judiciais concretos etc., fazem parte de concepções particulares do liberalismo que tentam, em alguma medida, se aproximar de seu conceito nuclear: a noção de garantia de alguns direitos do indivíduo perante a comunidade. Naturalmente, homens e mulheres razoáveis, bem informadas e bem intencionadas divergirão a respeito dos pormenores dessa concepção, o que não significa que estarão negando o compromisso inicial com o liberalismo. O compromisso que selamos com o liberalismo, neste trabalho, procura discernir criticamente a respeito das diversas concepções liberais propagadas, mas busca manter-se fiel ao núcleo do mais genuíno princípio da igualdade, do qual todas nossas conclusões buscarão emanar. Feito esse registro, cabe-nos examinar de que modo o princípio geral da igualdade se aplica ao sistema jurídico de uma democracia constitucional liberal.

Comumente se apregoa a existência de uma tensão, ou mesmo, mais radicalmente, de um paradoxo, um conflito irreconciliável entre igualdade e liberdade, donde uma ou outra inevitavelmente prevalecerão. Nesse sentido a igualdade estaria em tensão com outros princípios igualmente relevantes da comunidade de princípios constitucionais. Outras pessoas ressaltam que a igualdade, por si só, é uma ideia contraditória, pois ora requer seja levado em conta o igual tratamento dos indivíduos de modo cego tendo em vista sua situação contextual peculiar (o ideal de imparcialidade), ora requer seja levado em conta o tratamento diferenciado desses mesmos indivíduos segundo o próprio contexto peculiar anteriormente rechaçado para efeitos do abrigo do princípio da igualdade (o ideal de reconhecimento). Nesse sentido a igualdade comportaria uma tensão interna dentro de seu próprio conceito. Acreditamos que ambas essas tensões são reais e proveitosas, tanto inevitáveis quanto desejáveis, pois contribuem para complexificar e tornar mais útil o papel do argumento da 
igualdade na resolução justa de casos jurídicos controversos e na tomada de decisões políticas mais democráticas (SCOTT, 2005, p. 12).

O princípio da igualdade tem um conteúdo geral e abstrato que se desdobra em dois subprincípios (os quais podem ser reconhecidos a partir da análise criteriosa da legislação, da atividade de aplicação normativa dos tribunais e da prática argumentativa das doutrinadoras do direito, embora raramente ou nunca sejam assim nomeados): o subprincípio da identidade e o subprincípio da diferença. Identidade e diferença são os dois lados da mesma moeda da igualdade, os quais a coabitam e se autocondicionam mutuamente na formulação do argumento final. A identidade prescreve o igual respeito dos cidadãos da parte do Estado no sentido de Dworkin: pessoas (e grupos) deverão ser igualmente respeitadas sem que se leve em conta sua posição particular, suas idiossincrasias, seus méritos. Mas dificilmente a igualdade poderia ser o fundamento de uma democracia constitucional se fosse baseada meramente em uma noção tão simplória e míope, embora relevante; ${ }^{178}$ este princípio precisa ser complementado com uma componente mais sofisticada. Daí entrar a diferença na complexa estrutura do argumento da igualdade; a diferença estipula a igual consideração dos cidadãos e das cidadãs pelo Estado no sentido de Dworkin: pessoas (e grupos) deverão ser igualmente consideradas levando-se em consideração justamente as necessidades especiais, as idiossincrasias e as desvantagens que porventura venham a acometê-las, as quais são julgadas irrelevantes na outra etapa do argumento igualitário.

Tratando-se o princípio da igualdade como um argumento tanto fundante de uma concepção política adequada para a democracia constitucional quanto onipresente na feitura, na aplicação e na discussão normativa sobre direitos fundamentais, ressalta-se que identidade e diferença serão sempre argumentos em jogo nesse âmbito, articulados e considerados de maneira complexa e dinâmica, de modo dialético. A prevalência ora do aspecto da identidade, ora do aspecto da diferença, não poderia ser definida de antemão em uma lista exaustiva, de tal sorte que nem é possível nem é desejável construir-se um catálogo de casos-padrão e suas respectivas resoluções; pelo contrário, a justiça deve ser averiguada em cada caso particular à luz da melhor construção do argumento da igualdade para a situação em tela. É a

\footnotetext{
${ }^{178} \mathrm{O}$ chamado argumento metafórico (de identidade) conduz o raciocínio a níveis mais altos de abstração, no qual cada indivíduo é igual a qualquer outro indivíduo. Sua utilização pode ser altamente emancipatória e essencial para produzir justiça em alguns casos. Pensemos na juridicidade das relações homoafetivas: o Estado deve estender a proteção jurídica a essas relações do modo como estende às relações heteroafetivas; por outro lado, o Estado não possui justificativa para criminalizá-las na medida em que deve proteger igualmente a esfera de autonomia privada dos indivíduos na escolha de seus parceiros sexuais e afetivos, desde que adultos e plenamente capazes. Ver ROSENFELD, 2003ª (pp. 67, 72-73).
} 
irrepetibilidade de cada caso em sua singularidade e a consideração de seus aspectos únicos que pode assegurar a imparcialidade e a consequente decisão correta (CARVALHO NETTO, 2002, p. 83).

Por isso mesmo, aqui, no domínio dos discursos de aplicação normativa, faz-se justiça não somente na medida em que o julgador seja capaz de tomar uma decisão consistente com o Direito vigente, mas para isso ele tem que ser igualmente capaz de se colocar no lugar de cada um desses envolvidos, de buscar ver a questão de todos os ângulos possíveis e, assim, proceder racional ou fundamentalmente à escolha de uma única norma plenamente adequada à complexidade e à unicidade da situação de aplicação que se apresenta (CARVALHO NETTO, 2004a, p. 40).

Apenas gostaríamos de sugerir um critério ${ }^{179}$ para a interpretação do princípio da igualdade: o ideal político da igualdade de resultados (o qual não é propriamente um princípio, porém mais bem entendido enquanto objetivo ou meta da própria aplicação do direito) deve servir de parâmetro para a escolha da face adequada da igualdade tendo em vista a apreciação do problema. ${ }^{180} \mathrm{~A}$ aplicadora da norma deve avaliar os resultados de sua aplicação levando-se em conta tanto uma visão da identidade quanto uma visão da diferença, atentando-se para qual seria o resultado mais justo, a saber, a consequência prática que mais se coadunaria ao conjunto dos princípios constitucionais em sua integridade e às circunstâncias especiais do caso. Seguindo a lição de ROSENFELD (2003, pp. 114-115), o melhor equilíbrio que o sujeito constitucional pode esperar alcançar é a acomodação do máximo possível de diferenças, desde que não comprometa sua integridade.

\subsection{O princípio da liberdade identitária e o princípio da igualdade como diferença na identidade constitucional brasileira}

A Constituição da República Federativa do Brasil de 1988 traz extenso rol de direitos fundamentais individuais e coletivos, de natureza civil, política, social, econômica e cultural. Tal Constituição adota expressamente o Estado democrático de direito como paradigma (art.

\footnotetext{
${ }^{179}$ Esse critério pode ser complementado com o critério da razão suficiente apresentado por Robert Alexy (apud HABERMAS, 2003b, p. 154): quando exigir razão suficiente para um tratamento diferenciado, então se impõe um tratamento diferenciado.

${ }^{180}$ Do mesmo modo argumenta ROSENFELD (2003a, p. 85) a respeito da utilização alternativa dos processos metafóricos (que ressaltam identidades) e dos processos metonímicos (que ressaltam diferenças): "No domínio da argumentação jurídica, sobretudo, como já mencionado, a inclinação por processos metafóricos ou metonímicos é em grande medida determinada pelos interesses nos resultados jurídicos; os que desejam ampliar a aplicação de uma norma jurídica vigente apoiam-se na metáfora, ao passo que, os que buscam limitar o espectro de abrangência dessa norma recorrem à metonímia".
} 
$1^{\circ}$, caput), o que significa que assume como compromissos para o Estado a persecução de determinados fins públicos, como o asseguramento de direitos sociais e individuais, da liberdade, da segurança, e como a realização da igualdade e da justiça social "como valores supremos de uma sociedade fraterna, pluralista e sem preconceitos, fundada na harmonia social (...)" (CF-88, Preâmbulo). ${ }^{181}$ Além de dispor sobre a garantia de direitos individuais típicos do paradigma liberal (notadamente, no art. $5^{\circ}$ ), adota certos objetivos sociais de erradicação da desigualdade típicos do paradigma social (notadamente, no art. $3^{\circ}$ ), todos devidamente relidos sob o marco do paradigma do Estado democrático de direito. Como fundamentos de nossa Constituição republicana, destacaríamos a cidadania ( $\operatorname{art} .1^{\circ}$, II) e a dignidade da pessoa humana (art. $1^{\circ}$, III). Cidadania, nesse complexo sistemático, deve ser lida para além de sua tradicional acepção de gozo dos direitos de sufrágio, mas em direção à afirmação do amplo e multifário papel das cidadãs e dos cidadãos na condução da República, e no especial tratamento igualitário a ser dispensado a cada uma dessas cidadãs enquanto membros de uma mesma comunidade política coesa. Dignidade humana é o direito humano que fundamenta todos os direitos políticos da comunidade política constituída, como preleciona DWORKIN (2011, p. 343).

Expressa-se ainda a possibilidade de um direito "não explícito" ser reconhecido em virtude do sistema geral dos princípios adotados pela Constituição: "§2 $2^{\circ}$ Os direitos e garantias expressos nesta Constituição não excluem outros decorrentes do regime e dos princípios por ela adotados, ou dos tratados internacionais em que a República Federativa do Brasil seja parte". O próprio ordenamento constitucional positivo admite, pois, o caráter construtivo dos direitos enunciado por Dworkin, a possibilidade de um direito ser reconhecido judicialmente desde que possa ser fundamentado em considerações de justiça embasadas na teoria política subjacente ao regime político e ao complexo íntegro de princípios incorporados na Constituição. Também não resta dúvida alguma quanto à normatividade dos princípios mesmo daqueles "não explícitos"182 -, isto é, da capacidade de eles concederem direitos e

181 Faz parte da tradição constitucional brasileira a enunciação de um preâmbulo que antecede o texto constitucional. Este, porém, não possui caráter normativo, mas apenas enunciativo; não é fonte direta de direitos e obrigações nem norma que vincula o conteúdo das constituições dos Estados federados. No entanto, o preâmbulo consigna as intenções que permearam o trabalho constituinte e, não por acaso, contém princípios que serão reforçados durante todo o texto constitucional propriamente dito - esses princípios, sim, possuem inquestionável força normativa. Entendemos que os princípios que constam do preâmbulo são, em sua maior parte, reafirmados pelo texto constitucional, o que faz com que o preâmbulo seja uma importante ferramenta de interpretação e esclarecimento a respeito da teoria política subjacente à comunidade de princípios adotada pela Constituição brasileira. O STF se manifestou em sentido semelhante na ADI 2076, de 2003, de relatoria do Min. Carlos Velloso. Conferir MENDES, BRANCO (2012, p. 86).

182 A distinção entre direitos explícitos e implícitos, ou enumerados e não enumerados, é objeto de severa crítica de Dworkin (2003, pp. 180-183). Os princípios abstratos que estatuem direitos, interpretados à luz da leitura 
imporem obrigações, mesmo sem lei que os regulamente (“Art. $5^{\circ}, \S 1^{\circ}$ : As normas definidoras dos direitos e garantias fundamentais têm aplicação imediata").

$\mathrm{O}$ art. $5^{\circ}$ consigna um direito de nosso especial interesse: a liberdade de consciência (inciso VI). ${ }^{183}$ Embora disponha com maior detalhe sobre a liberdade de crença, seguindo a tradição liberal do direito à liberdade religiosa (“(...) sendo assegurado o livre exercício dos cultos religiosos e garantida, na forma da lei, a proteção aos locais de culto"), a liberdade de consciência abarca "uma determinação constitucional para que o Estado não interfira na esfera de pensamento do indivíduo, impondo-lhe concepções de qualquer ordem (filosóficas, religiosas, sociológicas etc.)" (FERNANDES, 2015, p. 383). De outro lado, está assegurado um direito à privacidade (inciso $\mathrm{X}$ ), ${ }^{184}$ condição para o autodesenvolvimento da personalidade, o qual inclui, nos moldes do liberalismo, o direito de controle do indivíduo sobre seus objetivos pessoais e projetos de vida, o direito de desenvolver sua personalidade sem coações e restrições externas e sem contar com a imposição de convicções abrangentes, seja por parte do Estado ou da coletividade. A partir da análise em conjunto dos direitos à liberdade de consciência e à privacidade, é possível reconhecer um princípio subjacente de liberdade identitária: a liberdade de consciência e a garantia da privacidade incluem o direito do indivíduo ao livre autodesenvolvimento de sua identidade, seja ela uma identidade cultural, étnica, racial, religiosa, de gênero ou sexual. E como a Constituição estabelece um princípio de não discriminação (art. 3, IV: "Constituem objetivos da República Federativa do Brasil: (...) promover o bem de todos, sem preconceito de origem, raça, sexo, cor, idade e quaisquer outras formas de discriminação") que veda "quaisquer outras formas de discriminação", concluímos que cada identidade pessoal, cultural ou social deve e pode exigir gozar do mesmo respeito atribuído pelo Estado e pela coletividade política. DUARTE (2008, p. 118) realiza uma lúcida explanação sobre o princípio da igualdade na Constituição brasileira e em que medida tal princípio fundamenta e exige ações afirmativas para pessoas negras. Valendonos de uma analogia com relação a seu argumento, adaptando-o ao caso da igualdade sexual, podemos compreender o seguinte desdobramento do princípio da igualdade: $a$ ) o subprincípio da não discriminação, que repudia as concepções heteronormatizantes; $b$ ) o subprincípio do

moral, dependem de percepções morais, não de regras linguísticas. Nesse sentido, nenhum direito decorre diretamente do texto, mas de considerações morais sobre a melhor interpretação daquele texto.

183 “Art. $5^{\circ}$ : Todos são iguais perante a lei, sem distinção de qualquer natureza, garantindo-se aos brasileiros e aos estrangeiros residentes no País a inviolabilidade do direito à vida, à liberdade, à igualdade, à segurança e à propriedade, nos termos seguintes: (...) VI - é inviolável a liberdade de consciência e de crença, sendo assegurado o livre exercício dos cultos religiosos e garantida, na forma da lei, a proteção aos locais de culto" (grifamos).

184 “Art. $5^{\circ}$ : (...) X - são invioláveis a intimidade, a vida privada, a honra e a imagem das pessoas, assegurado o direito à indenização pelo dano material ou moral decorrente de sua violação" (grifamos). 
pluralismo, que autoriza a defesa da diversidade como condição da dignidade humana e da construção de uma cultura republicana; e o c) subprincípio do combate à desigualdade, que obriga o Estado a eliminar as desigualdades historicamente estabelecidas entre heterossexuais e não-heterossexuais.

Deste modo, chegamos até um dos princípios constitucionais que fundamentam a adequação das políticas públicas de combate à homofobia nas escolas: o princípio de que todos os indivíduos (no caso, crianças e adolescentes que frequentam o ambiente escolar) devem ter a liberdade de formar, autodesenvolver e exercitar suas identidades sexuais e devem ter o direito correspondente de exigir igual respeito às "diferenças" expressas por suas identidades. O direito à educação necessariamente é compreendido em conciliação com o princípio do igual respeito das identidades.

\section{O Supremo Tribunal Federal (STF) manifestou-se recentemente em sentido} semelhante. A última palavra do tribunal constitucional, no âmbito do exercício de sua jurisdição constitucional, a respeito do conteúdo dos direitos fundamentais não exaure os debates e as disputas políticas ${ }^{185}$ sobre esse mesmo conteúdo; entretanto, a posição do tribunal supremo é um elemento de peso para a formatação da identidade constitucional. ${ }^{186}$ Aprendemos com Dworkin e Rosenfeld que a atividade interpretativa dos tribunais ${ }^{187}$ faz

\footnotetext{
185 Vejamos a advertência de ROSENFELD (2003a, p. 40) de que devemos evitar a personificação do sujeito constitucional, isto é, de que um sujeito ou órgão não detém o monopólio sobre o discurso constitucional: "Nem os constituintes nem os intérpretes da Constituição, nem os que se encontram sujeitos às suas prescrições são propriamente o sujeito constitucional. Todos eles formam parte do sujeito constitucional e pertencem a ele, mas o sujeito constitucional enquanto tal só pode ser apreendido mediante expressões de sua auto-identidade no discurso intersubjetivo que vincula todos os atores humanos que estão e serão reunidos pelo mesmo conjunto de normas constitucionais". No mesmo compasso adverte o Prof. Menelick de CARVALHO NETTO (2002, p. 84) sobre o risco de cedermos arbitrariamente a interpretação da Constituição a um determinado órgão: "Os princípios estruturantes do constitucionalismo, resgatados não na concepção jusnaturalista mas na ideia de integridade do direito, é que podem garantir a exigência de que a Constituição se apresente como algo que pertença intersubjetivamente a todos os cidadãos, pois base dessa comunidade de homens livres e iguais que vivem sob a égide das leis que fizeram para auto-regerem-se em sua vida em comum". Visão semelhante pode ser encontrada na tese da sociedade aberta dos intérpretes da Constituição de Peter HÄBERLE (1997).

186 Conferir ROSENFELD (2003a, p. 19), a propósito da relevância das decisões da Suprema Corte dos EUA para a formatação da identidade do sujeito constitucional estadunidense: "Assim não é possível que se apreenda uma quadro adequado da identidade constitucional dos Estados Unidos sem que se suplemente o texto constitucional com a longa corrente de interpretações e elaborações que perpassa dois séculos de decisões da Suprema Corte".

187 Adilson José MOREIRA (2010, pp. 55-66) apresenta uma série de precedentes judiciais, julgados difusamente por tribunais em todo o território nacional e anteriores ao próprio julgamento do STF em sede de ADI, que se debruçam sobre o casamento igualitário. Os tribunais se valeram de cinco estratégias argumentativas para excluir os casais homoafetivos do âmbito de regulação da união estável: uma interpretação literal da legislação em vigor, a identificação da função de procriação do casamento com os interesses sociais legitimamente tutelados pelo Estado, a caraterização da heterossexualidade como comportamento altruísta na medida em que tem como objetivo algo mais do que a autossatisfação - a procriação, o esvaziamento do caráter de afetividade das relações entre pessoas do mesmo sexo e sua inclusão no campo das relações patrimoniais e a correlação entre heterossexualidade e identidade nacional (p. 56).
} 
parte de nossa história institucional, e os precedentes têm certo caráter de obrigatoriedade não em virtude de serem em si fontes de lei, mas pelo fato de que o Estado deve agir com integridade, tratando a todos e a todas de forma igual segundo a concepção do que a igualdade significa em determinado regime político, em determinado momento histórico. A voz do Supremo Tribunal Federal é um relevante componente de nossa dinâmica e prospectiva identidade constitucional. Vejamos a compreensão do Supremo exarada na Ação Direta de Inconstitucionalidade $n^{\circ} 4277$, na qual o órgão tratou diretamente da extensão dos direitos de liberdade identitária e de igualdade como diferença às pessoas não-heterossexuais.

Na ocasião, as ministras e os ministros do STF tinham em mãos Ação Direta de Inconstitucionalidade (ADI) e Arguição de Descumprimento de Preceito Fundamental $(\mathrm{ADPF})^{188}$ que tratavam da atribuição de interpretação conforme à Constituição do art. 1723 do Código Civil, no intuito de decidir-se se a união civil entre pessoas do mesmo sexo poderia ter os mesmos efeitos jurídicos da união estável entre pessoas de sexo oposto. Isto é, o STF decidiria a respeito da constitucionalidade da união civil igualitária no Brasil, e em quais circunstâncias casais homoafetivos poderiam considerar-se no porte de direito subjetivo de exigir o registro civil de sua união. Aplicando a técnica da interpretação conforme à Constituição, o STF decidiu equiparar a união homoafetiva ao instituto jurídico da família (BRASIL, 2011c, p. 614). Mas o que nos interessa diretamente é a fundamentação utilizada pelos juízes e pelas juízas, a qual toca de frente nos princípios da igualdade como diferença e da liberdade identitária.

O Tribunal decidiu com base em um direito à preferência sexual plasmado na esfera de privacidade do indivíduo. Na ementa lê-se: "Reconhecimento do direito à preferência sexual como direta emanação do princípio da 'dignidade da pessoa humana': direito a auto-estima no mais elevado ponto da consciência do indivíduo" (Ibid., p. 612). O Relator, Min. Ayres Britto, refere-se a um constitucionalismo fraternal inspirado pela nossa Constituição, cujo objetivo é estabelecer a igualdade civil-moral mesmo das classes inferiorizadas; faz especial menção ao pluralismo e ao princípio da igualdade como diferença. A Constituição deixaria ao indivíduo a liberdade de atividade sexual ("a Constituição entrega o empírico desempenho de tais funções

\footnotetext{
188 Houve julgamento conjunto da ADI 4277-DF e da ADPF 132-RJ, propostas, respectivamente, pela Procuradoria-Geral da República e pelo Governador do Estado do Rio de Janeiro. O acórdão com o inteiro teor do voto dos ministros foi publicado em 5 de maio de 2011. Participaram como intimados do processo, representados por seus respectivos advogados, a Presidente da República, o Congresso Nacional, e como amici curiae as seguintes associações civis: Conectas Direitos Humanos, Associação Brasileiras de Gays, Lésbias e Transgêneros - ABGLT, Associação de Incentivo à Saúde e à Educação de São Paulo, Instituto Brasileiro de Direito de Família - IBDFAM, Associação Eduardo Banks, Conferência Nacional dos Bispos do Brasil - CNBB (BRASIL, 2011c, p. 616).
} 
sexuais ao livre arbítrio de cada pessoa"), devido ao silêncio normativo sobre tal matéria (Ibid., pp. 632, 635).

\begin{abstract}
Óbvio que, nessa altaneira posição de direito fundamental e bem de personalidade, a preferência sexual se põe como direta emanação do princípio da "dignidade da pessoa humana" (inciso III do art. $1^{\circ} \mathrm{da} \mathrm{CF}$ ) e, assim, poderoso fator de afirmação e elevação pessoal. Da auto-estima no mais ponto alto da consciência. (...) Afinal, se as pessoas de preferência heterossexual só podem se realizar ou ser felizes heterossexualmente, as de preferência homossexual seguem na mesma toada: só podem se realizar ou ser felizes homossexualmente (Ibid., p. 638).
\end{abstract}

Entendimento diferente, segundo Ayres Britto, faria a Constituição perder em coerência, pois nesse caso estaria impregnada de um discurso discriminatório, pois preconceituoso e homofóbico (Ibid., p. 649).

Os demais ministros e as demais ministras seguem destacando a liberdade sexual. A Ministra Cármen Lúcia assim se manifesta, a propósito da liberdade de escolha sexual: “o que se extrai dos princípios constitucionais é que todos, homens e mulheres, qualquer que seja a escolha do seu modo de vida, têm os seus direitos fundamentais à liberdade, a ser tratados com igualdade em sua humanidade, ao respeito, à intimidade devidamente garantidos" (Ibid., p. 699). A juíza lança mão de um argumento baseado no imperativo de coerência dos princípios constitucionais: "a Constituição deve ser interpretada como um conjunto harmônico de normas, no qual se põe uma finalidade voltada à concretização de valores nela adotados como princípio" (Ibid., p. 698). O Min. Gilmar Mendes chama a atenção para o direito de autodesenvolvimento de cada indivíduo, contemplado na ideia do exercício da liberdade (Ibid., p. 713) e para o princípio da não discriminação em razão da opção sexual (Ibid., p. 781). Em voto denso, complexo e bem fundamento nas mais modernas teorias sociais, políticas e jurídicas, o Min. Luiz Fux menciona textualmente o princípio da igualdade abstrata de Dworkin ("todos os indivíduos devem ser tratados com igual consideração e respeito"), o qual seria a base da leitural moral da Constituição (Ibid., p. 672); presta referência à "política de reconhecimento", presente no pensamento de filósofas como Hegel, Taylor, Honneth e Fraser, quando comenta que "os padrões heteronormativos de valor geram formas sexualmente específicas de subordinação de status" (Ibid., p. 676). Fux assim preleciona: "Compete ao Estado assegurar que a lei conceda a todos a igualdade de oportunidades, de modo que cada um possa conduzir sua vida autonomamente segundo seus próprios desígnios e que a orientação sexual não constitua óbice à persecução dos objetivos pessoais" (Ibid., p. 673). Nesse mesmo diapasão, o Min. Joaquim Barbosa refere-se a um 
direito ao reconhecimento existente em nosso ordenamento constitucional, o qual estaria sendo violado quanto o Estado deixa de tratar certos grupos de cidadãs sem o devido respeito social (Ibid., p. 725).

Finalmente, a maioria da Corte acredita estar agindo legitimamente ao interpretar a Constituição - ao empreender uma verdadeira leitura moral sobre a Constituição - devido ao caráter contramajoritário da jurisdição constitucional e ao caráter contramajoritário dos direitos fundamentais garantidos às minorias. Tal argumento ocupa centralidade em votos como do Min. Marco Aurélio Mello (Ibid., p. 820), do Min. Gilmar Mendes (Ibid., p. 804) e do Min. Luiz Fux (Ibid., p. 668); este destaca o papel da Corte Constitucional enquanto instância que protege os direitos das minorias, garantindo a igualdade material e evitando “discriminações odiosas”, pois o Estado não pode ser indiferente à discriminação por orientação sexual (Ibid., p. 669). Os votos dos ministros e das ministras do STF podem ser entendidos segundo a categoria de leitura moral da Constituição, segundo uma compreensão comunitária e contramajoritária da democracia constitucional, e conforme a ideia de que questões de princípio possuem primazia em um Estado constitucional. E este Estado deve avançar cada vez mais em direção à efetivação desses princípios, até o momento em que todos os cidadãos e todas as cidadãs possam ver-se contempladas com os mesmos direitos e possam, enfim, confiar na legitimidade moral de sua própria comunidade política. $\mathrm{O}$ direito à liberdade identitária e o correspondente direito ao igual respeito dessa liberdade (igualdade como diferença) fazem parte da identidade constitucional brasileira, estão presentes em nosso sistema constitucional e, agora, sem sombra de dúvidas, na nossa história jurisprudencial. 


\title{
CONSIDERAÇÕES FINAIS - POLÍTICAS PÚBLICAS DE COMBATE À HOMOFOBIA NAS ESCOLAS E O SISTEMA CONSTITUCIONAL BRASILEIRO: O direito à educação para a diferença e a função da educação
}

Chegamos até o direito à educação enquanto fundamento das políticas públicas de combate à homofobia nas escolas. A Constituição Federal consagra o direito à educação dentre os direitos sociais fundamentais ${ }^{189}$ (art. $6^{\circ}$, caput), atribui a responsabilidade por sua consecução ao Estado e à família, em colaboração com a sociedade, e elege como seu escopo o "pleno desenvolvimento da pessoa, seu preparo para o exercício da cidadania e sua qualificação para o trabalho" (art. 205, caput, grifamos). Portanto, é objetivo da educação, em nosso sistema constitucional, propiciar ao sujeito as condições de seu autodesenvolvimento pessoal, as quais incluem como premissa a liberdade identitária e o igual tratamento. Podemos confirmar essa interpretação com base nos princípios constitucionais que orientam a educação:

\begin{abstract}
Art. 206: O ensino será ministrado com base nos seguintes princípios: I - igualdade de condições para o acesso e permanência na escola; II - liberdade de aprender, ensinar, pesquisar e divulgar o pensamento, a arte e o saber; III - pluralismo de ideias e concepções pedagógicas, e coexistência de instituições públicas e privadas de ensino; IV - gratuidade do ensino público em estabelecimentos oficiais; (...) VI gestão democrática do ensino público, na forma da lei (...).
\end{abstract}

Princípios como igualdade de condições de acesso e permanência, liberdade de pensamento, pluralismo de ideias e concepções e gestão democrática do ensino orientam a concepção de educação a ser adotada pela escola brasileira. No mesmo tom segue a Lei de Diretrizes e Bases da Educação Nacional (LDB - Lei nº 9394/1996). Seu art. $2^{\circ}$ acrescenta que a educação será inspirada nos ideais da solidariedade humana e seu art. $1^{\circ}$ expande o conceito de educação, a qual, embora seja predominantemente desenvolvida em instituições próprias $\left(\S 1^{\circ}\right)$, também inclui as experiências "na vida familiar, na convivência humana, no trabalho, nas instituições de ensino e pesquisa, nos movimentos sociais e organizações da sociedade civil e nas manifestações culturais" (caput).

O direito à educação, corretamente concebido na integridade do sistema constitucional brasileiro, deve ser lido como um direito plural, emancipatório e igualitário, o que consiste em dizer, finalmente, que esse direito deve assegurar um tipo de educação voltada para a

189 “Art. 6: São direitos sociais a educação, a saúde, a alimentação, o trabalho, a moradia, o transporte, o lazer, a segurança, a previdência social, a proteção à maternidade e à infância, a assistência aos desamparados, na forma desta Constituição". 
diferença. Para examinarmos a melhor leitura do direito à educação, antes foi imprescindível examinarmos qual é a melhor leitura dos direitos fundamentais à luz de nossa constituição e, antes mesmo disso, qual a melhor leitura do próprio constitucionalismo. Partindo das conclusões indicadas, podemos seguramente afirmar o papel de catalisador da diferença no sistema educacional constitucional. O direito à educação deve ser plural porque, apenas dessa forma, preenche o pressuposto do igual respeito e da igual consideração de todas as cidadãs brasileiras, um princípio que requer sejam criadas e cultivadas condições de florescimento do pluralismo de ideias, credos, cosmovisões e formas de vida; emancipatório porque a educação é responsável por fomentar a autonomia dos sujeitos que dela se servem, autonomia essa que é contemplada, no nível educacional, quando crianças e adolescentes podem exercer livremente e desenvolver sem coações os potenciais de sua personalidade, o que quer dizer de sua identidade enquanto processo; igualitário no sentido duplo do princípio da igualdade: do tratamento equânime e da especial atenção às necessidades especiais daquelas submetidas aos processos educacionais. Uma educação igualitária é ao mesmo tempo uma educação para a diferença, e se traduz em um direito. Mas que tipo de direito é esse? E qual relação ele guarda com as políticas públicas de combate à homofobia nas escolas? E, finalmente, qual é o modelo de educação mais adequado à luz de nossa experiência constitucional?

Vimos no Capítulo 2 que os direitos, na teoria de Dworkin aqui adotada, podem ser classificados em preferenciais ou institucionais, abstratos ou concretos, políticos ou jurídicos, e as juízas só podem tomar uma decisão imperativa sobre quais direitos e obrigações uma parte tem com base em um direito institucional, concreto e jurídico. $\mathrm{O}$ direito a uma educação para a diferença é propriamente um direito institucional, concreto e jurídico com base no qual juízas podem determinar sua aplicação, ou faz parte do espectro de direitos de outra natureza? Sem dúvida, o direito à educação cotejado à luz dos princípios da liberdade identitária e da igualdade como diferença é um direito $(a)$ institucional, porque, como já demonstramos, faz parte da exata compreensão do sistema constitucional brasileiro e pode servir de justificação para decisões de instituições públicas. Nada impediria o Congresso Nacional aprovasse uma lei determinando a observação de certos parâmetros que obrigassem as escolas a promover um ensino que respeite a liberdade sexual das estudantes e crie um ambiente favorável ao tratamento igualitário de suas identidades sexuais; aliás, esse era inicialmente o viés do Plano Nacional de Educação (PNE) para o decênio de 2011-2020 (Lei nº. 8035/2010). As políticas públicas voltadas para a inclusão da diversidade sexual nas escolas públicas, promovidas pelo Governo Federal (conferir a seção 1.3 do Capítulo 1), são fundamentadas em um complexo 
de direitos que incluem o direito a uma educação livre, plural, igualitária e emancipatória, reconhecido como um direito institucional capaz de obrigar a atuação do Poder Público, através da Presidência da República, de seus ministérios e de suas secretarias, na direção de sua concretização; isso porque, até agora, esse direito não se trata de um direito concreto.

(b) Esse direito não é concreto na medida em que não contempla em si mesmo suas condições de aplicação, nem seu peso atribuível diante de outros objetivos políticos. Nem por isso deixa de ser um direito, isto é, continua sendo uma questão de princípio que deverá ser levada em conta na atividade pública do Estado e deverá prevalecer sempre que confrontado com metas sociais de uma maioria que queira decidir por educar suas filhas segundo uma moral sexual heteronormativa e homofóbica. Enquanto direito abstrato, o direito à educação para a diferença é um princípio que deverá sempre levar a atuação do Poder Público na direção que mais aproximadamente o promova. Por isso se justificam a legitimidade constitucional e a especial urgência da efetivação de políticas públicas de combate à homofobia nas escolas, mesmo a despeito de lei que as determine. Uma juíza, ao apreciar um caso que envolve o direito à educação, deve levar em consideração essa leitura includente e igualitária, pois, mesmo que não aplique diretamente esse direito em tal configuração, deve tomá-lo em conta ao interpretar e aplicar um direito concreto que se relacione a ele. Isso porque, mesmo se tratando de um direito abstrato, mantém seu status de direito político.

(c) A distinção entre direitos políticos (political rights) e direitos jurídicos ou legais ${ }^{190}$ (legal rights) merece melhores esclarecimentos, pois é um ponto central de nossa argumentação. Os direitos políticos em sentido estrito são direitos que cidadãs e cidadãos portam em determinada comunidade, inclusive a favor ou contra o Estado e a coletividade, mas são de tal forma amplos e gerais que não podem ser aplicados diretamente em âmbito judicial, mas apenas como razão para a aplicação de um direito jurídico, o qual fundamentam. A prática do direito implica que "as pessoas tenham, entre outros direitos políticos, direitos com uma característica especial: estes são direitos legais, porque podem ser impostos a pedido numa instituição política decisória, como um tribunal” (DWORKIN, 2011, p. 413). Os direitos jurídicos da teoria de Dworkin correspondem aproximativamente ao que, na tradição romano-germânica, conhecemos como direitos subjetivos: direitos subjetivos são pretensões

\footnotetext{
${ }^{190}$ A tradução portuguesa do livro Justiça para Ouriços, de DWORKIN (2011), traduz a expressão "legal rights" como direitos legais. Contudo, acreditamos que a melhor tradução para o contexto de cultura jurídica brasileira seria a expressão "direitos jurídicos", pois, nos países de tradição romano-germânica, o conceito de lei (legal) e direito (jurídico) não equivalem, ao contrário dos países de tradição anglo-saxã, onde direito e lei estão consubstanciados na mesma palavra,"law", donde o adjvetivo "legal" viria a corresponder ao que conhecemos como "jurídico" (algo mais amplo do que o meramente legal).
} 
juridicamente tuteladas que exigem uma prestação por parte de outrem - do Estado ou de um indivíduo em particular ou da coletividade em geral - que pode inclusive ser cobrada judicialmente, caso em que a autoridade judicial, verificando a obrigatoriedade da prestação, determina seu cumprimento. Nem todos os direitos declarados por uma constituição são propriamente jurídicos, ou seja, diretamente aplicáveis a pedido dos cidadãos privados (Ibid., p. 421). Seria suficientemente esclarecedor transcrever um longo trecho em que Dworkin elabora mais detidamente essa distinção:

\begin{abstract}
Os direitos políticos só podem ser distinguidos dos direitos morais pessoais numa comunidade que tenha desenvolvido alguma versão daquilo que Hart chamou regras secundárias: regras que estabelecem autoridade legislativa, executiva e decisória, bem como jurisdição. Os direitos legais só podem ser distinguidos dos outros direitos políticos, se essa comunidade tiver, pelo menos, uma versão embrionária da separação de poderes descrita por Montesquieu. É, então, necessário distinguir duas classes de direitos e deveres políticos. Os direitos legislativos são direitos de os poderes legislativos da comunidade poderem ser exercidos de certa maneira: para criar e administrar um sistema de ensino público, por exemplo, e para não censurar a expressão política. Os direitos legais são aqueles que as pessoas podem exercer quando necessário, sem outra intervenção legislativa, em instituições decisórias que dirigem o poder executivo do xerife ou da polícia [por exemplo]. (...) Os direitos legislativos têm de esperar pela sua vez; numa democracia, os humores da política determinarão que direitos legislativos serão exercidos e quando. Os direitos legais estão sujeitos a humores diferentes, mas, em princípio, permitem que os membros individuais da comunidade garantam aquilo que querem através de processos diretamente disponíveis. Os direitos legislativos, mesmo quando reconhecidos, não têm força imediata; os direitos legais, depois de reconhecidos, são imediatamente aplicáveis, quando necessário, através de instituições decisórias e não de instituições legislativas. A distinção não tem, necessariamente, consequência sociológica. As reivindicações de direitos legislativos desempenham um papel importante na política, mesmo quando têm poucas hipóteses de serem reconhecidos na ação parlamentar; os direitos legais desempenham o seu papel mais importante na vida social e comercial quando não há perspectivas ou sequer interesse de uma imposição decisória. No entanto, a distinção é filosoficamente esclarecedora: mostra-nos como devemos compreender as teorias políticas e as teorias do direito. A filosofia política geral trata, entre muitas outras coisas, dos direitos legislativos. Uma teoria do direito trata dos direitos legais, mas é uma teoria política, porque procura uma resposta normativa para uma questão política normativa: em que condições as pessoas adquirem direitos e deveres genuínos que sejam aplicáveis quando necessário na forma descrita? (2011, p. 415).
\end{abstract}

O direito à educação que respeite a liberdade identitária e trate igualmente a identidade do indivíduo pode ser em um aspecto um direito jurídico ou noutro aspecto um direito legislativo no sentido acima descrito, case se pense no exercício desse direito individual ou coletivamente. Individualmente, um sujeito, ao ter sua identidade desrespeitada no espaço escolar, pode cobrar do Estado uma indenização ou algum outro tipo de reparação devido a um trato abusivo que viola os princípios constitucionais que orientam a atividade de ensino. No caso, a proteção da identidade sexual trata-se de um direito individual de cada aluna e, 
uma vez ferido esse direito, é suficiente, em um primeiro momento, que o Estado se limite a prover alguma reparação ou alguma outra atitude protetiva que não exceda o nível individual. Em sentido diverso, uma coletividade de pessoas não poderia exigir judicialmente que o Estado promova ativamente determinadas políticas públicas, mas tal vácuo pode ser objeto de reivindicações públicas pelo cumprimento de um direito legislativo que é requerido pela nossa Constituição e deve ser concretizado, o quanto antes, pela legislação. A reivindicação por políticas públicas que combatam a homofobia é uma pretensão embasada na teoria política adotada pelo sistema constitucional da Constituição de 88, e uma atuação positiva do Estado na direção de erradicar a homofobia é nada mais que o cumprimento dos princípios constitucionais. Mas outros princípios poderiam tornar absurda a hipótese de uma cidadã exigir judicialmente toda a mobilização do aparato estatal para a realização planejada de uma política pública, tais como o princípio da separação de poderes, que distribui organicamente o poder político entre instituições legislativas, executivas e judiciárias. Isto é, mesmo se tratando de um direito político, os tribunais aplicariam, nessa hipótese, "apenas parte daquilo a que os cidadãos têm direito" (Ibid., p.421). De modo que se existe um sistema educacional devidamente implementado no Brasil, esse sistema deve obedecer a princípios normativos, entre os quais o princípio de que todas as estudantes sujeitas ao sistema escolar deverão ser tratadas com o devido respeito e com a igual consideração. Esta é a melhor chave de leitura para entender as políticas públicas: se um indivíduo não pode exigir do Judiciário uma ordem para a implantação de uma política pública, de outro modo pode exigir que as instituições do Estado o tratem com igual consideração e respeito. E reivindicações ao nível de direitos individuais, assim como reivindicações coletivas públicas, também podem pressionar o Estado a promover políticas públicas.

É hora de retornarmos às políticas públicas de combate à homofobia que nos propusemos analisar sob o ponto de vista jurídico-constitucional. No Capítulo 1 (seção 1.3), expusemos uma reconstrução do debate em âmbito governamental, realizado com participação da sociedade civil, desde a Conferência Mundial de Beijing em 1995, o qual passou a ganhar maior destaque e projeção mundial a partir da Conferência Mundial da ONU em Durban, África do Sul, no ano de 2001. Políticas públicas contra a homofobia na sociedade brasileira passaram a ser arquitetadas pelo Governo Federal desde 2002 (a partir da segunda versão do Programa Nacional de Direitos Humanos - PNDH II) e atingiram seu ponto culminante com a implantação do Programa Brasil Sem Homofobia (PBSH) em 2004. O PBSH já previa ações voltadas especificamente para o campo da educação emancipatória, 
que deveriam tematizar gênero e diversidade sexual nos currículos escolares, e tal entendimento veio a ser reiterado no Plano Nacional de Educação em Direitos Humanos (PNEDH, de 2006), no Plano Nacional de Promoção da Cidadania e Direitos Humanos LGBT (PNPCDH/LGBT, de 2009) e no Projeto Escola Sem Homofobia (PESH, de 2011). Como já salientamos, todas essas ações governamentais tiveram suas dificuldades de concretização, derivadas principalmente da ferrenha oposição política que, não por acaso, têm gerado. No entanto, são de singular importância para a realização do direito à educação para a diferença, visto que sinalizam esforços, por parte do Estado, direcionados à erradicação ou minoração da homofobia, não obstante as lutas e tensões internas presentes dentro das próprias instituições estatais.

Por se tratarem de questões de princípio relativas a direitos fundamentais e a princípios de justiça, indubitavelmente há razões deveras persuasivas para a continuidade da luta dos movimentos LGBT em prol do reconhecimento de seus direitos mais básicos através de uma direta atuação do Poder Público. E a luta pela educação plural, emancipatória e igualitária faz parte do asseguramento da cidadania, da dignidade humana e da igualdade em um Estado democrático de direito, à medida que uma educação para a diferença é pressuposto do livre exercício e (auto)desenvolvimento das identidades pessoais e sociais e do igual tratamento de cidadãs e cidadãos em nossa sociedade política. Essas políticas públicas são adequadas constitucionalmente: $a$ ) de um ponto de vista da teoria constitucional, apoiam-se nos legítimos direitos das minorias, em uma democracia constitucional, de serem igualmente respeitadas e terem sua autoestima protegida e promovida; $b$ ) de um ponto de vista jurídicoconstitucional, sustentam-se em um plexo de direitos constitucionais como o direito à educação para a diferença, interpretado à luz dos princípios da liberdade identitária e do princípio da igualdade como diferença; e $c$ ) de um ponto de vista sociológico e antropológico, são políticas de reconhecimento transformativas que potencializam a possibilidade de contestação das relações de poder hierárquicas que geram exclusões sociais.

(a) As políticas públicas que analisamos são políticas destinadas a garantir direitos de grupos minoritários: os plurais e heterogêneos grupos que designamos como sexualidades oprimidas são minoritários à medida que dispõem de poucas chances de fazerem valer seus interesses no espaço político e que são subvalorizados no marco de nossa tradição cultural. Mas o "argumento da democracia" - de que essas políticas devem ser barradas porque feririam um senso de moralidade convencional coletiva defendido pelas maiorias - não é um argumento forte o bastante para sua obstrução. Vimos que nosso conceito de democracia vai 
além de um conceito meramente majoritário, instrumental e estatístico, pois, a partir do momento em que adotamos o ideal do constitucionalismo e os direitos como proteções contramajoritárias que dele decorrem, passamos a adotar uma democracia constitucional que se compromete com o igual tratamento de todas as pessoas, especialmente das minorias. A democracia constitucional é a melhor concepção democrática para harmonizar as tradicionais contraposições entre princípios liberais e republicanos na política, e, para sua plena realização, requer atitudes públicas que minimizem as desigualdades existentes e estabeleçam uma igualdade social pressuposta para o regular exercício da igualdade política. As políticas públicas que analisamos se enquadram perfeitamente na concepção de democracia constitucional que defendemos: são políticas que fortalecem a democracia brasileira em toda sua amplitude. Nesses termos, a discussão sobre (o respeito às plurais) sexualidades deve deixar o confinamento do espaço privado das instituições familiares e chegar até o espaço público da discussão política.

(b) As políticas públicas que analisamos são coerentes com a concepção de direitos fundamentais endossada pelo sistema constitucional brasileiro. Como aprendemos, consoante a tese de Dworkin, direitos são proteções das minorias com relação às maiorias, garantias de que a atividade estatal e comunitária se orientará segundo princípios de justiça. Políticas públicas de combate à homofobia promovem uma série de direitos constitucionais, dentre os quais destacamos enfaticamente o direito à educação para a diferença, o qual inclui em seu espectro interpretativo os princípios constitucionais da liberdade identitária e da igualdade como diferença. O direito à educação tal qual esboçamos, nunca é demais repetir, é um direito institucional que faz parte de nosso sistema jurídico e pode ser aplicado pelas instituições legislativas (quando se tratar de um direito legislativo que conduz a atividade legiferante em uma certa direção) e pelas instituições judiciárias (quando se tratar de um direito jurídico individual que pode ser prontamente aplicado pela autoridade judicial). Esse conjunto coerente de direitos é a base jurídica mencionada pelas políticas públicas de erradicação da violência homofóbica. Senão vejamos.

O PBSH adota como princípios a perspectiva da não-discriminação por orientação sexual, do enfrentamento de todas as formas de discriminação e violência e da promoção dos direitos de LGBT nas políticas públicas e estratégicas do Governo Federal. Em termos legais, o princípio da educação inclusiva no Brasil está amparado na LDB (Lei no 9.394/96), que assegura o direito à escola de todas as pessoas sem discriminação de singularidades ou características específicas de indivíduos ou grupos humanos. O PNDH II, elaborado em 2001 
para ser implementado a partir de 2002, destaca direitos à liberdade de expressão, de crença e culto e de orientação sexual. Dentre outras medidas, propõe apoiar uma emenda à Constituição Federal ${ }^{191}$ que inclua a garantia do direito à livre orientação sexual e a proibição da discriminação por orientação sexual. A criação da SECAD/MEC, em 2004, veio atender à promoção de políticas e atividades didático-pedagógicas "voltadas a garantir a igualdade de direitos e oportunidades de todos os indivíduos ou grupos, independentemente de suas diferenças de gênero, identidade de gênero ou orientação sexual (...)" (SECRETARIA, 2007, p. 9). E o PESH repousa no princípio do igual respeito e da igual dignidade a ser conferida a todas as identidades sexuais, defendido no Documento da Conferência Nacional de Educação Básica, realizada em Brasília em abril de 2008, onde se lê que "só há educação, no sentido pleno do termo, se ela for inclusiva e respeitar a diversidade" (BRASIL, 2011a, p. 79). ${ }^{192}$

(c) Defendemos que políticas públicas de promoção de direitos das sexualidades oprimidas devem ser atravessadas pela perspectiva transformativa do reconhecimento. ${ }^{193} \mathrm{O}$ PESH, por meio do seu conteúdo constituído por um Caderno, 6 Boleshs e três audiovisuais, exprime claramente uma perspectiva teórica desconstrucionista e transformativa: "busca-se desocultar a ordem que coloca a heterossexualidade como natural, normal e única possibilidade de os sujeitos viverem suas sexualidades, por meio de dinâmicas de trabalho que (...) favoreçam a reflexão e incentivem mudanças" (Ibid., p. 12). A escola é reconhecida como um locus de produção e reprodução social de preconceitos já enraizados em toda a sociedade e em suas instituições. "As práticas escolares, compreendidas como intervenção pedagógica, transmitem e reproduzem modelos de comportamento, sensibilidade e racionalidade próprios da cultura, com seus respectivos recursos técnicos, emocionais e ideológicos" (Ibid., p. 67). O PESH sustenta um modelo pedagógico político (do qual falaremos a seguir) que busca desmistificar a aparente normalidade e estabilidade das relações de poder que criam desigualdades entre heterossexuais e não-heterossexuais e suas consequentes relações de subordinação; nesse sentido, podemos reafirmá-lo como altamente transformativo e

\footnotetext{
${ }^{191}$ É válida a mobilização em torno de uma emenda constitucional que inclua expressamente a discriminação por orientação sexual como forma de discriminação vedada e que consagre textualmente um direito à livre orientação sexual. Todavia, como já demonstramos, o direito à livre orientação sexual (o que chamamos de princípio da liberdade identitária) e a vedação da discriminação sexual já decorrem da melhor interpretação moral e sistemática de nossa Constituição, sem prejuízo de uma suposta lacuna na lei ou na literalidade do texto constitucional.

${ }^{192}$ Conferir toda a discussão esboçada no Capítulo 1, a respeito da licitude das políticas públicas de combate à homofobia, sobretudo conferir a seção 1.3.

193 Conferir a defesa das políticas de reconhecimento transformativas, em oposição às políticas de reconhecimento afirmativas, na primeira parte da seção 1.3 do Capítulo 1.
} 
desestabilizador e, não por acaso, polêmico e temido por parte dos grupos que historicamente se beneficiam da desigualdade provocada pela heteronormatividade.

Sabemos que essas políticas, embora exigidas pelo conjunto de princípios adotados pela Constituição Federal em sua integridade, têm encontrado uma série de obstáculos ${ }^{194}$ para sua plena efetivação. Mas as aparentes derrotas legislativas sinalizam para uma esperança ainda em chama. Afinal, a luta das pessoas comprometidas com a cidadania LGBT ainda continua, senão no âmbito da produção legislativa, também no âmbito da interpretação jurídica. Como nos adverte o Prof. Menelick de CARVALHO NETTO (2004b, p. 70), o Legislativo é apenas a porta de entrada dos argumentos no sistema jurídico:

O risco aqui é que os movimentos percam de vista que a conquista de um determinado texto legislativo é apenas um início. Que o que de imediato pode lhes parecer uma desastrosa derrota por alterações sofridas pelo texto inicialmente proposto, na verdade, pode e deve significar apenas, uma vez que o reconhecimento do princípio fundamental de igualdade pretendido tenha sido alcançado, a continuidade da luta por sua afirmação, agora no campo específico da aplicação do Direito, tomando como ponto de partida precisamente a positivação desse reconhecimento.

A luta pela inclusão se serve do caráter permanentemente aberto da identidade constitucional, a qual incorpora, através da tecitura aberta dos direitos fundamentais, novas proteções àqueles sujeitos excluídos por meio do reconhecimento de novos direitos fundamentais: ${ }^{195}$

\begin{abstract}
A nossa história constitucional não somente comprova isso, como possibilita que repostulemos a questão da identidade constitucional como um processo permanente em que se verifica uma constante tensão extremamente rica e complexa entre a inclusão e a exclusão e que, ao dar visibilidade à exclusão, permite a organização e a luta pela conquista de concepções cada vez mais complexas e articuladas da afirmação constitucional da igualdade e da liberdade de todos. Este é um desafio à compreensão dos direitos fundamentais; tomá-los como algo permanentemente aberto, ver a própria Constituição formal como um processo permanente e, portanto mutável, de afirmação da cidadania (CARVALHO NETTO, 2003, p. 145).
\end{abstract}

\footnotetext{
${ }^{194}$ Conferir Capítulo 1, seção 1.4, onde mostramos os argumentos de ataque às políticas públicas de sexualidade que pressionaram o veto presidencial do PESH e o veto da inclusão da igualdade de gênero e orientação sexual no PNE.

195 Os direitos fundamentais só podem cumprir fielmente seu papel emancipatório se se abrirem a um permanente processo de aquisição de novos direitos fundamentais, como preceitua nossa Constituição (art. $5^{\circ}$, $\S 2^{\circ}$ ), se mantiverem sua natureza reflexiva. Como pessoas, precisamos nos manter permanentemente abertas a um processo construtivo, "capazes de aprender com as nossas experiências, com as nossas vivências, de nos tornamos reflexivamente pessoas cada vez melhores, como também como sujeito coletivo, como identidade constitucional, como povo, (...) como cidadãos que reciprocamente se respeitam em suas diferenças, que foi a própria trajetória do constitucionalismo, como exigência universal de liberdade e de igualdade de todos" (CARVALHO NETTO, 2003, p. 155).
} 
Uma vez demonstrado que as políticas públicas de combate à homofobia nas escolas são adequadas do ponto de vista de uma teoria constitucional, do conjunto de direitos fundamentais plasmado no sistema constitucional brasileiro - na medida em que se coadunam à nossa identidade constitucional - e das teorias sociológicas e antropológicas contemporâneas sobre a formação de identidades nos processos educacionais, passemos à questão seguinte: qual é o modelo de educação mais adequado para enfrentar a discriminação homofóbica de acordo com nossa experiência constitucional?

Já afirmamos alhures que as escolas são espaços públicos pela razão de $a$ ) formarem e transforem identidades sociais através das práticas pedagógicas curriculares e informais e $b$ ) estarem forçosamente abertas a públicos de alunas plurais, heterogêneos, multiculturais, provenientes de grupos sociais os mais diversificados. A escola é um ambiente onde uma miríade de identidades sociais diversas e por vezes conflitantes dividirão o mesmo espaço e serão submetidas a uma mesma práxis pedagógica; por esse motivo, a escola, num Estado constitucional democrático secular e comprometido com o pluralismo, deve estar aberta para lidar adequadamente com a diversidade. As escolas têm feito isso vulgarmente adotando o princípio liberal da tolerância do Outro: “A tolerância do diferente, nesta conjuntura contemporânea, significa, em muitos casos, a permissão para que todos os grupos sociais se manifestem dentro da ordem concebida como legítima" (RUIZ, 2003, p. 150). Entretanto, sustentamos que esse princípio é inadequado para conduzir uma educação emancipatória, uma pedagogia que leve a sério a diferença, mormente nos casos em que sexualidades marginalizadas adentram no espaço escolar e sofrem toda sorte de preconceitos e discriminações condensadas no conceito de homofobia. Isso porque a tolerância, não obstante as boas e nobres intenções daquelas pessoas que a proclamam, impede que vejamos a identidade e a diferença como processos de produção social que envolvem relações de poder.

O simbolismo da tolerância estimula uma noção de pluralismo que oculta os interesses dos grupos dominantes e legitima as estruturas de dominação. Articula-se a diversidade, entendida aqui como naturalizada, com o caráter permanente e não controvertido das estruturas sociais, legitimando-se as desigualdades como se elas fossem de origem cultural. É nesse contexto em que RAWLS (2000) afirma o fato do pluralismo. A tolerância passa por 
uma ressignificação hermenêutica que lhe atribui a função de legitimação simbólica do poder. ${ }^{196}$

Em lugar da perspectiva da tolerância, RUIZ (2003) propõe a alteridade como critério de diálogo intersubjetivo: "a defesa do mundo da vida e a busca da felicidade do outro são critérios que devem definir, dentro de um leque plural de possibilidades, a bondade ou a perversidade de uma forma cultural e dos modelos de sociedade que a veiculam" (Ibid., p. 158). Substituir a tolerância pela alteridade nos possibilita colocarmo-nos no lugar do Outro e pelo menos buscarmos compreender sua dor, seu sofrimento, suas dificuldades. Embora não possamos nos transportar completamente para sua perspectiva, esse esforço é um caminho promissor para abrir um diálogo intersubjetivo e intercultural mais frutífero que vincule pluralismo com responsabilidade. Para além da tolerância indiferente, que é uma base pouco sólida para estabelecer a solidariedade social, a responsabilidade de cada pessoa pelo destino de todas as outras gera "uma prática em direção à transformação social das estruturas e instituições que produzem a vítima, assim como a uma mudança cultural do sistema ético (simbólico) que legitima seus mecanismos de poder" (Ibid., p. 166).

Pensar a educação a partir dos princípios da tolerância e da alteridade desvenda dois diferentes modelos pedagógicos com pressupostos e consequências completamente distintas. Cabe-nos avaliar quais desses modelos representam uma adequada prática pedagógica para criar um ambiente favorável à inclusão das diferentes identidades sexuais. No primeiro deles, um modelo liberal fundamentado na perspectiva de tolerância, estimula-se o cultivo dos bons sentimentos e da boa vontade para com a chamada "diversidade cultural", partindo-se do pressuposto de que a diversidade é natural e sua legítima existência deve ser respeitada ou tolerada. O problema central dessa abordagem é que ela deixa de questionar as relações de poder e os processos de diferenciação que produzem identidade e diferença, com se estas fossem produzidas ao acaso, resultando-se assim em novas dicotomias: a dominante tolerante/ a dominada tolerada. Partindo-se da tolerância não é possível conceber práticas realmente transformativas das opressões institucionais existentes.

\footnotetext{
196 A tolerância acarreta vários efeitos políticos indesejados: a) o indiferentismo: tolera-se o diferente porque é indiferente para mim, isto é, ser tolerante significa ser individualista e buscar somente os próprios interesses com indiferença à dor e ao sofrimento do Outro; b) a alienação política: renuncia-se à luta social, pois a desigualdade social passa a ser legitimada como natural, como se fosse providencial respeitarmos a biodiversidade cultural; c) o paternalismo: a ideia de caridade, de aceitação benevolente daquele que é inferior a mim, mas nunca colocado em status de igualdade, e nunca se questionando por que e através de quais mecanismos a diferença produz a desigualdade (RUIZ, 2003, pp. 151-153).
} 
Por outro lado, um modelo político (e politizado) fundado na alteridade trataria a identidade e a diferença como questões políticas, isto é, como produções que têm lugar no confronto de relações de poder. Deixa-se de reconhecer e celebrar a diferença e passa-se a questioná-la e, principalmente, a problematizar por que a diferença causa a desigualdade social. "A pedagogia e o currículo deveriam ser capazes de oferecer oportunidades para que as crianças e os/as jovens desenvolvessem capacidades de crítica e questionamento dos sistemas e das formas dominantes de representação da identidade e da diferença" (SILVA, 2003, p. 92). Somente um modelo político de abordagem da identidade e da diferença, centrado no conhecimento do sofrimento que a exclusão causa na vítima, é potencialmente capaz de conduzir às transformações institucionais que o desafio da inclusão apresenta à escola. $\mathrm{O}$ modelo político de educação é promissor para o enfrentamento da homofobia e para a promoção da dignidade das sexualidades oprimidas no espaço educacional.

Assim devemos conceber uma política pública tal qual o Projeto Escola Sem Homofobia: como uma iniciativa que possibilite às crianças serem suficientemente informadas do caráter social de seu modo individual de expressão, conscientizadas das lógicas de poder que demarcam as diferenças, apetrechadas de meios para escolherem livremente seu modo de manifestar sua sexualidade sob a garantia de que não serão hostilizadas por essa escolha - principalmente quando o exercício de sua sexualidade não se tratar de uma escolha, mas de uma autocompreensão sem a qual a própria experiência do Eu não faria qualquer sentido. Os grupos conservadores estão certos ao dizer que a "celebração" de identidades nãoheterossexuais causaria um abalo na estrutura familiar tal qual a entendemos hoje, na medida em que questionariam e eventualmente alterariam as representações sociais negativas que hoje temos a respeito das sexualidades marginalizadas. A questão ao qual nos reportamos é: isso é necessariamente ruim? Esse processo social que parece inevitável deve ser evitado? E se deve ser evitado, em nome de que $(\mathrm{m})$ o será e benefícios a quem trará? A quem interessa (e a quem não interessa) a manutenção da "família tradicional”? Para lidar com essas questões, lançamos a instigante exortação de Richard Johnson (apud LOURO, 1997, p. 49): "Devemos sempre policiar os limites sexuais e congelar nossas formas de viver? Por que não podemos ver a diversidade sexual como uma fonte de construção de algumas novas possibilidades?”.

Se a diversidade sexual pode ser vista como uma fonte de construção de algumas novas possibilidades, indicamos que as políticas públicas de combate à homofobia nas escolas apresentadas nesta dissertação são um caminho promissor para tal desfecho. A cultura, em uma sociedade complexa, plural, multicultural e democrática, necessita de reflexividade: é 
preciso que os sujeitos que a compõem sejam capazes de exercitar sua autonomia no espaço público a fim de poderem trabalhar pela transformação de sua própria cultura, naqueles aspectos em que ela parece mais perversa, mais excludente, mais obsoleta. As pressões sociais em nossa jovem democracia nos mostram, todos os dias, que a homofobia é uma prática social institucionalizada na cultura cujos dias - no que depender das militantes que esperam por uma vida social mais justa - estão contados. Esperamos que assim o seja. E o direito não pode abdicar de seu papel potencialmente transformativo, pois, mesmo que reconheçamos o caráter majoritariamente conservador das instituições jurídicas - e, na verdade, de todas as instituições sociais - , os direitos fundamentais, em um Estado democrático de direito regido por uma constituição, introduzem no espaço público uma abertura para disputas políticas em torno de seu conteúdo. É exatamente essa abertura que nos faz confiarmos na legitimidade de nossas instituições democráticas, que nos faz lutarmos dia após dia por um mundo que pareça mais ajustado aos nossos anseios. E não seria por outro modo senão pela educação que conseguiríamos chegar à tão sonhada promessa de justiça social que uma sociedade solidária faz pressupor. 


\section{REFERÊNCIAS}

\section{$\underline{\text { I-Livros, artigos e periódicos }}$}

ABRAMOVAY, Miriam; CASTRO, Mary Garcia; SILVA, Lorena Bernadete da (2004). Juventudes e sexualidade. Brasília: UNESCO.

ALEXY, Robert (2005). La institucionalización de la justitia. Trad.: José A. Seonne, Eduardo R. Sodero y Pablo Rodríguez. Granada: Editorial Comares, 2005. (Tradução nossa).

(2008). Teoria dos Direitos Fundamentais. Trad.: Virgílio Afonso da Silva. São Paulo: Malheiros Editores.

ALMEIDA, Miguel Vale de (2003). "Antropologia e Sexualidade: consensos e conflitos teóricos em perspectiva histórica". In: A sexologia: perspectiva multidisciplinar. Org.: Lígia Fonseca, C. Soares e Júlio Machado Vaz. Coimbra: Quarteto, Vol. II, p. 53-72.

AMARAL JR., Ilmar Pereira do (2013). Entre Justiça e Ética: direitos humanos e democracia nas sociedades pluralistas. Monografia (Graduação em Direito) - Faculdade de Direito, Universidade Federal de Uberlândia, Uberlândia.

BARROSO, Luís Roberto (2009). Curso de Direito Constitucional contemporâneo. $1^{\mathrm{a}}$ ed. São Paulo: Editora Saraiva.

BELLO, Alexandre Toaldo; FELIPE, Jane (2009). "Construção de comportamentos homofóbicos no cotidiano da educação infantil”. In: JUNQUEIRA, Rogério Diniz (org.). Diversidade Sexual na Educação: problematizações sobre a homofobia nas escolas. Brasília: Ministério da Educação, Secretaria de Educação Continuada, Alfabetização e Diversidade, UNESCO, pp. 141-157.

BIROLI, Flávia. Família: novos conceitos (2014). São Paulo: Editora Fundação Perseu Abramo.

BUTLER, Judith. "Corpos que pesam: sobre os limites discursivos do sexo" (2000). In: LOURO, Guacira Lopes (org.). O corpo educado: pedagogias da sexualidade. Trad.: Tomaz Tadeu Silva. $2^{\mathrm{a}}$ ed. Autêntica: Belo Horizonte.

CARRARA, Sérgio; SIMÕES, Júlio Assis (2007). “A trajetória da identidade homossexual masculina na antropologia brasileira". Cadernos Pagu (928), janeiro-junho, pp. 65-99.

CARVALHO NETTO, Menelick de (2003). "A hermenêutica constitucional e os desafios postos aos direitos fundamentais". In: SAMPAIO, José Adércio Leite (org.). Jurisdição constitucional e direitos fundamentais. Belo Horizonte: Del Rey, pp. 141-163.

(2002). "A contribuição do Direito Administrativo

enfocado na ótica do administrado para uma reflexão acerca dos fundamentos do controle de constitucionalidade das leis no Brasil: um pequeno exercício de Teoria da Constituição". In: Revista TST, Brasília, vol. 68, abril-junho de 2002, pp. 67-84.

(2004a). "A hermenêutica constitucional sob o paradigma do Estado democrático de direito". In: OLIVEIRA, Marcelo Andrade Cattoni (org.). Jurisdição e hermenêutica constitucional no Estado democrático de direito. Belo Horizonte: Mandamentos, pp. 25-44. 
(2004b) "Uma reflexão constitucional acerca dos direitos fundamentais do portador de sofrimento ou transtorno mental em conflito com a lei". In: Veredas do Direito, v. 1, janeiro-junho de 2004, Belo Horizonte: Escola Superior Dom Helder Câmara, pp. 67-80.

; SCOTTI, Guilherme (2011). Direitos fundamentais e a (in)certeza do direito: a produtividade das tensões principiológicas e a superação do sistema de regras. Belo Horizonte: Editora Fórum.

CAVALEIRO, Maria Cristina; VIANNA, Cláudia (2011). "Políticas Públicas de Educação e Diversidade: Gênero e (Homo)sexualidades”. In.: Gênero. Niterói, v. 12, n. 12, pp. 27-45, 1. sem.

CITTADINO, Gisele (2009). Pluralismo, direito e justiça distributiva: elementos da filosofia constitucional contemporânea. Rio de Janeiro: Lumen Juris.

COELHO, André Luiz Souza (2013). "O paradoxo dos direitos como trunfos: entre os níveis conceitual, normativo e intuitivo". In: Amazônia Em Foco. Ed. Especial: Temas Contemporâneos de Direitos Humanos, n. 2, pp. 22-40, nov. 2013.

COHEN, Jean L. (2012). "Repensando a privacidade: autonomia, identidade e a controvérsia sobre o aborto". Trad.: André Villalobos. Rev.: Flávia Biroli. In: Revista Brasileira de Ciência Política, nº 7, Brasília, janeiro - abril de 2012, pp.165-203.

COLLING, Leandro (2013). “A igualdade não faz meu gênero - em defesa das políticas das diferenças para o respeito à diversidade sexual e de gênero no Brasil”. In: Contemporânea Revista de Sociologia da UFSCar. São Carlos, v.3, n.2, julho-dezembro, 2013, pp.405-427.

COSTA, Alexandre Araújo (2008). Direito e Método: diálogos entre a hermenêutica filosófica e a hermenêutica jurídica. Tese (Doutorado em Direito) - Faculdade de Direito, Universidade de Brasília, Brasília.

DENNINGER, Erhard (2003). “'Segurança, diversidade e solidariedade' ao invés de 'liberdade, igualdade e fraternidade"'. In: Revista brasileira de estudos políticos, $\mathrm{n}^{\circ} 88$. Belo Horizonte: Editora UFMG, pp. 21-45.

DUARTE, Evandro Charles Piza (2007). "Princípio da Isonomia e Critérios para a Discriminação Positiva nos Programas de Ação Afirmativa para Negros (afro-descendentes) no Ensino Superior". In: ABC Revista de Direito Administrativo Constitucional, ano 7, n. 27, jan./mar.2007. Belo Horizonte: Fórum.

DWORKIN, Ronald (1985). A matter of principle. Cambridge: Cambridge University Press.

Paulo: Martins Fontes.

(1999). O império do direito. $1^{\text {a }}$ ed. Trad.: Jefferson Luiz Camargo. São

(2003). "O drama constitucional”. In: Domínio da vida: aborto, eutanásia e liberdades individuais. Trad.: Jefferson Luiz Camargo. São Paulo: Martins Fontes, pp. 165-205.

São Paulo: Martins Fontes.

(2006). O direito da liberdade. $1^{\mathrm{a}}$ ed. Trad.: Marcelo Brandão Cipolla. 
Paulo: Martins Fontes.

(2007). Levando os direitos a sério. $2^{\mathrm{a}}$ ed. Trad.: Nelson Boeira. São (2011). Justiça para ouriços. Trad.: Pedro Elói Duarte. Coimbra:

Edições Almedina.

ELSTER, Jon (1988). “Constitutionalism and democracy: Introduction" (1988). In: ; SLAGSTAD, Rune (org.). Constitutionalism and democracy. Cambridge: Cambridge University Press, pp. 1-18. (Tradução nossa).

FACCHINI, Regina; SIMÕES, Júlio Assis (2009). Na trilha do arco-íris: do movimento homossexual ao LGBT. São Paulo: Editora Fundação Perseu Abramo.

FERNANDES, Bernardo Gonçalves (2015). Curso de Direito Constitucional. $7^{\mathrm{a}}$ ed. Salvador: Editora JusPodivm.

FOUCAULT, Michel (1988). História da sexualidade: a vontade de saber. Vol I. $13^{\mathrm{a}}$ ed. Trad.: Maria Thereza da Costa Albuquerque e J. A. Guilhon Albuquerque. Rio de Janeiro: Edições Graal.

FRASER, Nancy (1990). "Rethinking the public sphere: a contribution to the critique of actually existing democracy". In: Social Text, No. 25/26, pp. 56-80. (Tradução nossa).

justicia en una época "postsocialista",. In:

(1997). "De la redistribución al reconocimiento?: dilemas en tomo a la críticas desde la posición "postsocialista". Siglo de Hombres Editores: Santa Fé de Bogota pp. 17-54. (Tradução nossa).

FRY, Peter; MacRAE, Edward (1985). O que é homossexualidade. (Coleção Primeiros Passos: 26). São Paulo: Abril Cultural: Brasiliense.

FURLANI, Jimena (2009). "Direitos humanos, direitos sexuais e pedagogia queer: os que essas abordagens têm a dizer à Educação Sexual?”. In: JUNQUEIRA, Rogério Diniz (org.). Diversidade Sexual na Educação: problematizações sobre a homofobia nas escolas. Brasília: Ministério da Educação, Secretaria de Educação Continuada, Alfabetização e Diversidade, UNESCO, pp. 293-323.

GÜNTHER, Klaus (2009). "Interpretações liberais e teórico-discursivas dos direitos humanos". In: FRANKENBERG, Günther; MOREIRA, Luiz (org.). Jürgen Habermas, 80 anos - Direito e Democracia. Rio de Janeiro: Editora Lumen Juris, pp. 219-237.

HALL, Stuart (2003). “Quem precisa de identidade?”. In: HALL, Stuart (org.). Identidade e Diferença - A Perspectiva dos Estudos Culturais. Petrópolis: Vozes.

HÄBERLE, Peter (1997). Hermenêutica Constitucional: A Sociedade Aberta dos intérpretes da Constituição: contribuição para a interpretação pluralista e procedimental da Constituição. Trad.: Gilmar Ferreira Mendes. Porto Alegre: Sergio Antonio Fabris Editor.

HABERMAS, Jürgen (1994). "Lutas pelo reconhecimento no Estado democrático constitucional". In: TAYLOR, Charles. Multiculturalismo - examinando a política de reconhecimento. Trad.: Marta Machado. Lisboa: Instituto Piaget, pp.125-164.

(2002). A inclusão do outro: estudos de teoria política. Trad.: George

Sperber, Paulo Astor Soethe e Milton Camargo Mota. São Paulo: Loyola. 
(2003a). Direito e democracia: entre facticidade e validade. Vol. 1. Trad.: Flávio Beno Siebeneichler. Rio de Janeiro: Tempo Brasileiro.

(2003b). Direito e democracia: entre facticidade e validade. Vol. 2. Trad.: Flávio Beno Siebeneichler. Rio de Janeiro: Tempo Brasileiro.

HOLMES, Stephen (1988). "Precommitment and the paradox of democracy". In: ; SLAGSTAD, Rune (org.). Constitutionalism and democracy. Cambridge: Cambridge University Press, pp. 195-240. (Tradução nossa).

HONNETH, Axel (2001). "Recognition or Redistribution? Changing Perspectives on the Moral Order of Society”. In: Theory, Culture \& Society, Vol. 18 (2-3). (Tradução nossa).

IRINEU, Bruna (2014). "10 anos do Programa Brasil Sem Homofobia: notas críticas”. In: Revista Temporalis, Brasília, ano 14, n. 28, pp.193-220, julho-dezembro de 2014.

JUNQUEIRA, Rogério Diniz (2009). "Educação e homofobia: o reconhecimento da diversidade sexual para além do multiculturalismo liberal". Diversidade Sexual na Educação: problematizações sobre a homofobia nas escolas. Brasília: Ministério da Educação, Secretaria de Educação Continuada, Alfabetização e Diversidade, UNESCO, pp.367-444.

LOURO, Guacira Lópes (1997). "Gênero, sexualidade e poder”. In: Gênero, sexualidade e educação. Petrópolis, RJ: Vozes.

(2000). "Pedagogias da sexualidade". In:

(org.). O corpo educado: pedagogias da sexualidade. Trad.: Tomaz Tadeu Silva. $2^{\mathrm{a}}$ ed. Autêntica: Belo Horizonte.

(2009). "Heteronormatividade e homofobia". In: JUNQUEIRA, Rogério Diniz (org.). Diversidade Sexual na Educação: problematizações sobre a homofobia nas escolas. Brasília: Ministério da Educação, Secretaria de Educação Continuada, Alfabetização e Diversidade, UNESCO, pp. 85-93.

MENDES, Conrado (2008). Controle de constitucionalidade e democracia. Rio de Janeiro: Elsevier Editora.

MENDES, Gilmar Ferreira; BRANCO, Paulo Gustavo Gonet (2012). Curso de Direito Constitucional. $7^{\mathrm{a}}$ ed. São Paulo: Editora Saraiva.

MIGUEL, Luís Felipe (2005). “Teoria democrática atual: esboço de mapeamento". In: BIB Revista Brasileira de Informação Bibliográfica em Ciências Sociais, $\mathrm{n}^{\circ}$ 59. São Paulo, pp. 542 .

MOREIRA, Adilson José (2010). “A construção jurídica da heterossexualidade”. In: Revista de Informação Legislativa. Brasília a. 47 n. 188 out./dez. 2010.

MOUFFE, Chantal (1999). "Por un pluralismo agonístico". In: El retorno de lo político: comunidade, ciudadanía, pluralismo, democracia radical. Barcelona: Paidós. (Tradução nossa).

OKIN, Susan Moller (2008). "Gênero, o público e o privado". Trad.: Flávia Biroli. In: Revista Estudos Feministas, Florianópolis, 16[2]:440, maio - agosto, 2008, pp. 305-332. 
PAIXÃO, Cristiano; BIGLIAZZI, Renato (2011). História constitucional inglesa e norteamericana: do surgimento à estabilização da forma constitucional. Brasília: Editora Universidade de Brasília.

PATEMAN, Carole (1989). "Feminist critiques of the public/private dichotomy". In: In: The disorder of women. Stanford: Stanford University Press, pp.

118-140. (Tradução nossa).

PHILLIPS, Anne (1997). "So what's wrong with liberal democracy?". In:

Engendering Democracy. Pennsylvania: Pennsylvania State University Press, pp. 147-168.

RAWLS, John (2000). "A teoria da justiça como equidade: uma teoria política, e não metafísica". In: Justiça e Democracia. Org.: Catherine Audard. Trad.: Irene A. Paternot. São Paulo: Martins Fontes, pp.199-241.

RIBEIRO, Darcy (1977). "Sobre o Óbvio". In: Simpósio sobre Ensino Público na $29^{a}$ Reunião da SBPC. São Paulo: Mimeo, jul. 1977.

RIOS, Roger Raupp (2009). "Homofobia na perspectiva dos direitos humanos e no contexto dos estudos sobre preconceito e discriminação". In: JUNQUEIRA, Rogério Diniz (org.). Diversidade Sexual na Educação: problematizações sobre a homofobia nas escolas. Brasília: Ministério da Educação, Secretaria de Educação Continuada, Alfabetização e Diversidade, UNESCO, pp. 53-83.

ROCKEFELLER, Steven C. (1994). "Comentário". In: TAYLOR, Charles. Multiculturalismo - examinando a política de reconhecimento. Trad.: Marta Machado. Lisboa: Instituto Piaget, pp.105-115.

ROSENFELD, Michel (2003a). A identidade do sujeito constitucional. Trad.: Menelick de Carvalho Netto. Belo Horizonte: Mandamentos.

(2003b). "O constitucionalismo americano confronta o novo paradigma constitucional de Denninger". In: Revista brasileira de estudos políticos, $\mathrm{n}^{\circ} 88$. Belo Horizonte: Editora UFMG, pp. 47-79.

RUIZ, Castor M. M. Bartolomé (2003). "O (Ab)uso da Tolerância na Produção de Subjetividades Flexíveis". In: SIDEKUN, Antônio. Alteridade e Multiculturalismo. Rio Grande do Sul: Unijuí, pp. 116-171.

SANDEL, Michael (2013). Justiça: o que é fazer a coisa certa. Trad.: Heloísa Marias e Maria Alice Máximo. São Paulo: Civilização Brasileira.

SANTOS, Lígia (2012). Diversidade sexual nas escolas: o caso do kit do Projeto Escola Sem Homofobia. Monografia (Graduação em Psicologia) - Centro Universitário de Brasília (UniCEUB), Brasília.

SCOTT, Joan W. (2005). "O enigma da igualdade". In: Revista Estudos Feministas, Florianópolis, 13(1): 216, janeiro-abril, pp. 11-30.

SEFFNER, Fernando (2009). "Equívocos e armadilhas na articulação entre diversidade sexual e políticas de inclusão escolar". In: JUNQUEIRA, Rogério Diniz (organizador). Diversidade Sexual na Educação: problematizações sobre a homofobia nas escolas. Brasília: Ministério da Educação, Secretaria de Educação Continuada, Alfabetização e Diversidade, UNESCO, pp. 125-139. 
SILVA, Tomaz Tadeu (2003). A Produção Social da Identidade. In:

(Org.). Identidade e Diferença - A Perspectiva dos Estudos Culturais. Petrópolis: Vozes.

SUNSTEIN, Cass (1988). "Constitutions and democracies: an epilogue". In:

SLAGSTAD, Rune (org.). Constitutionalism and democracy. Cambridge: Cambridge University Press, pp. 327-356.

TAYLOR, Charles (1994). "A política de reconhecimento". In: TAYLOR, Charles. Multiculturalismo - examinando a política de reconhecimento. Trad.: Marta Machado. Lisboa: Instituto Piaget, pp.45-94.

WEEKS, Jeffrey (2000). "O corpo e a sexualidade". In: LOURO, Guacira Lopes (org.). $O$ corpo educado: pedagogias da sexualidade. Trad.: Tomaz Tadeu Silva. $2^{a}$ edição. Autêntica: Belo Horizonte.

YOUNG, Iris M. (1990). "Five faces of oppression". In: Justice and the politics of difference. Princeton: Princeton University Press, pp. 39-65. (Tradução nossa).

(2012). "O ideal de imparcialidade e o público cívico". Trad.: Roberto Cataldo. Revisão de trad.: Flávia Biroli. In: Revista Brasileira de Ciência Política, n.9, Brasília, setembro - novembro de 2012, pp. 169-204.

\section{II - Legislação, jurisprudência e documentos oficiais}

BRASIL (1940). Decreto-Lei $n^{o}$ 2848, de 7 de dezembro de 1940 (Código Penal). Publicado no Diário Oficial da União em 31 de dezembro de 1940.

(1988). Constituição da República Federativa do Brasil. Brasília, DF: Senado Federal: Centro Gráfico, 292 p.

(1996). Congresso Nacional. Lei $n^{o}$ 9394, de 20 de dezembro de 1996 (Lei de Diretrizes e Bases da Educação Nacional). Publicada no Diário Oficial da União em 23 de dezembro de 1996.

(2001). Congresso Nacional. Lei $n^{o}$ 10172, de 9 de janeiro de 2001 (Plano Nacional de Educação). Publicado no Diário Oficial da União em 10 de janeiro de 2001.

(2002). Congresso Nacional. Lei $n^{o}$ 10406, de 10 de janeiro de 2002 (Código Civil). Publicada no Diário Oficial da União em 11 de janeiro de 2002.

(2006) Congresso Nacional. Projeto de Lei da Câmara nº 122/2006.

(2010). Congresso Nacional. Projeto de Lei $n^{o} 8035 / 2010$.

(2011a). Projeto Escola Sem Homofobia. Caderno Escola Sem Homofobia.

Secretaria de Educação Continuada, Alfabetização e Diversidade (SECAD/ MEC).

(2011b). Secretaria de Direitos Humanos. Relatório sobre violência homofóbica no Brasil. Ano de 2011b.

(2011c). Supremo Tribunal Federal. Ação direta de inconstitucionalidade $n^{o}$ 4277/DF - Distrito Federal. Relator: Ministro Ayres Britto. Pesquisa de Jurisprudência, 
Acórdãos, $05 \quad$ maio 2011.2 Disponível em: <http://stf.jusbrasil.com.br/jurisprudencia/20627236/acao-direta-de-inconstitucionalidade-adi4277-df-stf>. Acesso em: 20 de fevereiro de 2016. (2012) Congresso Nacional. Projeto de Lei da Câmara $n^{o}$ 103/2012.

CONSELHO Nacional de Combate à Discriminação (2004). Brasil Sem Homofobia: Programa de combate à violência e à discriminação contra GLBT e promoção da cidadania homossexual. Brasília: Ministério da Saúde.

REPROLATINA (2011). Projeto Escola Sem Homofobia. Relatório Técnico Final.

SECRETARIA de Educação Continuada, Alfabetização e Diversidade (SECAD/ MEC) (2007). Gênero e diversidade sexual na escola: reconhecer diferenças e superar preconceitos. Cadernos SECAD.

SECRETARIA Especial dos Direitos Humanos, Presidência da República (2009). Plano Nacional de Promoção da Cidadania e Direitos Humanos de LGBT. Brasília, SDH. 